\title{
Botas militares para salvar la democracia: miradas a las acciones de pacificación en la gobernación de Caldas 1953-1964
}

Jhon Jaime Correa Ramírez

Natalia Agudelo Castañeda Edwin Mauricio López García

Wilton Holguín Rotavista Anderson Andrés López Urrea

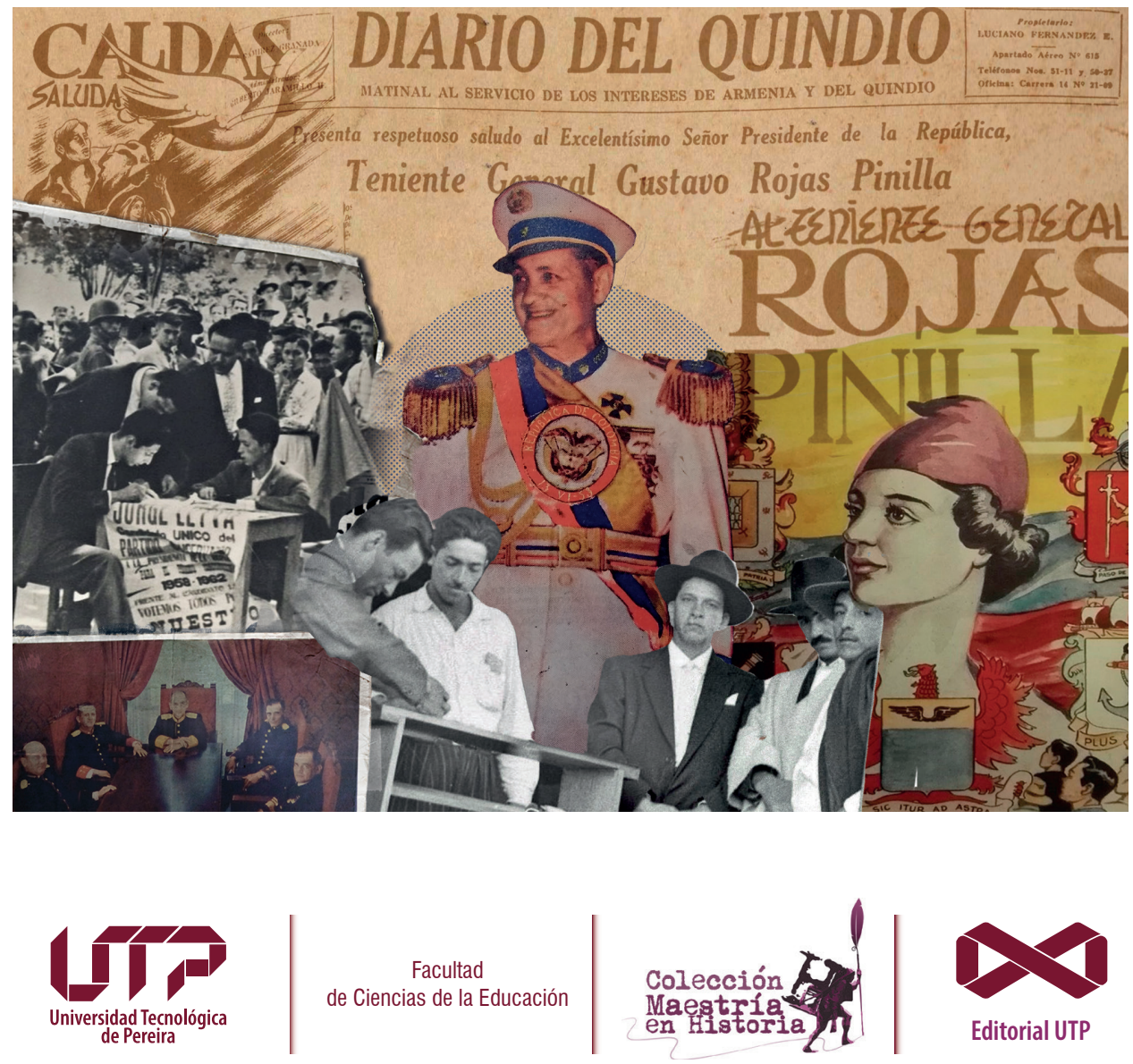


Jhon Jaime Correa Ramírez, (Medellín, Colombia, 1966).

Historiador de la Universidad Nacional de Colombia sede Medellín, Especialista en Gestión y Promoción Cultural de la Universidad de Antioquia, Magíster en Ciencia Política del Instituto de Estudios Políticos de la Universidad de Antioquia, y Doctor en Ciencias de la Educación de la Universidad Tecnológica de Pereira-RUDECOLOMBIA. Docente titular de la Escuela de Ciencias Sociales de la Facultad de Ciencias de la Educación de la Universidad Tecnológica de Pereira. Director de la Maestría en Historia de la Universidad Tecnológica de Pereira, y co-director del Grupo interinstitucional de Investigación UIS-UTP "Políticas, Sociabilidades y Representaciones Histórico-Educativas (PSORHE)", clasificado de categoría Al ante Colciencias. Tutor semillero en investigación formativa en "Historia, Cultura Política y Educación" de la UTP.

Es autor entre varios títulos de Civismo y educación en Pereira y Manizales (1925-1950): Análisis comparativo de sociabilidades, visiones de ciudad y cultura cívica. Pereira: Editorial UTP, 2015; Coautor de De Tinta Roja. Prensa, política y educación durante la República Liberal (1930-1946): El Diario de Pereira y Vanguardia Liberal de Bucaramanga. Bucaramanga: UIS, 2016. y de Facultad de Ciencias de la Educación UTP: 50 años en la Construcción de un Proyecto Educativo para una Nueva Región 1967-2017. Editorial UTP, 2018.

Miembro del grupo de investigación Políticas, Sociabilidades y Representaciones Históricas - Educativas. 


\section{Botas militares para salvar la democracia: miradas a las acciones de pacificación en la gobernación de \\ Caldas 1953-1964}

Jhon Jaime Correa Ramírez

Natalia Agudelo Castañeda Edwin Mauricio López García

Wilton Holguín Rotavista Anderson Andrés López Urrea

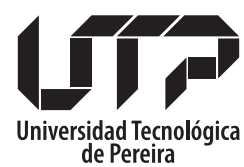

Facultad de Ciencias de la Educación Colección Trabajos de Investigación Colección Maestría en Historia 2020 
Botas militares para salvar la democracia : miradas a las acciones de pacificación en la gobernación de Caldas

1953-1964 / Jhon Jaime Correa Ramírez y otros. --

Pereira : Editorial Universidad Tecnológica de

Pereira, 2020.

265 páginas. -- (Colección Trabajos de investigación).

ISBN: 978-958-722-482-5

1. Historia - Caldas (Colombia) 2. Gobierno militar - Caldas

(Colombia) - 1953-1957 3. Democracia - Caldas (Colombia)

4. Política y gobierno - Caldas (Colombia) - 1953-1956

5. Grupos comunistas - Caldas (Colombia) 6. Violencia -

Caldas (Colombia) 7. Caldas (Colombia) - 1953-1964

CDD. 986.135

Botas militares para salvar la democracia: miradas a las acciones de pacificación en la Gobernación de Caldas 1953-1964

(C) Jhon Jaime Correa Ramírez

(C) Natalia Agudelo Castañeda

(C) Edwin Mauricio López García

(C) Wilton Holguín Rotavista

(C) Anderson Andrés López Urrea

(c) Universidad Tecnológica de Pereira

ISBN: 978-958-722-482-5

eISBN: 978-958-722-484-9

Proyecto de Investigación: Botas para salvar la

democracia en la Gobernación de Caldas (1953-1967), inscrito con el código 4-17-9

Universidad Tecnológica de Pereira

Vicerrectoría de Investigaciones, Innovación y Extensión

Editorial Universidad Tecnológica de Pereira

Pereira, Colombia

Coordinador editorial:

Luis Miguel Vargas Valencia

luismvargas@utp.edu.co

Teléfono 3137381

Edificio 9, Biblioteca Central "Jorge Roa Martínez"

Cra. 27 No. 10-02 Los Álamos, Pereira, Colombia

www.utp.edu.co

Montaje y producción:

María Alejandra Henao Jiménez

Universidad Tecnológica de Pereira

Pereira

Impresión y acabados:

Gráficas Olímpica

Pereira 


\section{Agradecimientos}

Queremos expresar nuestros agradecimientos a las personas e instituciones que nos apoyaron a lo largo de este proceso de investigación. A Gabriel David Samacá Alonso por su colaboración y lectura crítica, la cual contribuyó en gran medida a llevar a buen término este producto. AAnderson Paul Gil y Michael Stiven Valencia Villa por su apoyo y disposición para ayudarnos en la revisión de varios textos.

A Guillermo Aníbal Gärtner Tobón, Ricardo de los Ríos Tobón y Alfredo Cardona Tobón, por la valiosa información que nos brindaron sobre su experiencia personal y familiar durante estos años. A Robert Karl y Jefferson Jaramillo Marín quienes nos aportaron distintas miradas para la comprensión de la violencia y de la paz en el país y en la región, desde el relato de sus vivencias y de sus amplios recorridos en el 
oficio de investigar. A Juan Carlos Castro, secretario del Concejo Municipal de Chinchiná, por abrirnos el espacio en el archivo del municipio. A Luis Fernando Sánchez, Francisco Javier González y Alba Lucía Hurtado Pérez por abrirnos las puertas en la Cátedra de Historia Regional de Manizales donde pudimos socializar algunas de las ponencias que se han convertido en artículos de este libro.

De igual modo, queremos agradecer a todo el equipo de la Maestría en Historia de la Universidad Tecnológica de Pereira (UTP) y a los integrantes del grupo de investigación Políticas, Sociabilidades y Representaciones Histórico-Educativas (PSORHE), quienes siempre nos han brindado su respaldo académico y han estado muy al tanto de los resultados de esta investigación.

Por último, procuramos señalar que este libro fue terminado en los tiempos del Coronavirus (COVID-19), por tanto, les damos las gracias a nuestras familias por su comprensión e incondicional apoyo. 


\section{CONTENIDO}

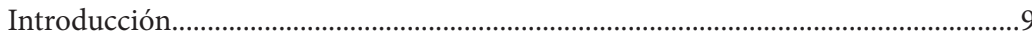

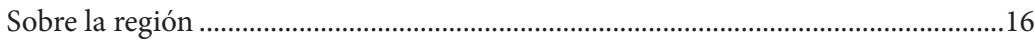

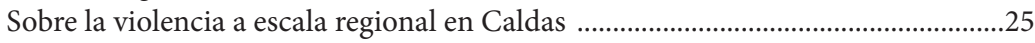

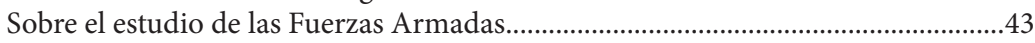

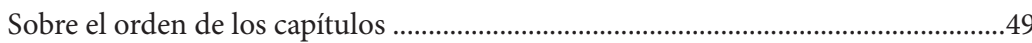

\section{CAPÍTULO UNO.}

Prensa regional y los gobiernos militares en Caldas (1953-1957):

el retorno a la democracia, la censura y la violencia política......................................57

1.1. La prensa regional: actor político y cultural de la sociedad.............................61

1.2. La llegada de los militares al poder vista desde la prensa regional................64

1.3. La disputa en la prensa caldense por el régimen militar a nivel nacional y regional ..................................................................................................

1.4. Adhesión conservadora y disidencia liberal al régimen a nivel

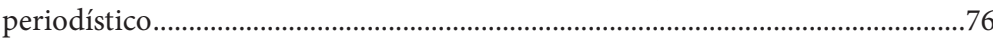

1.5. El Binomio de Calarcá: la prensa regional del régimen y la sombra

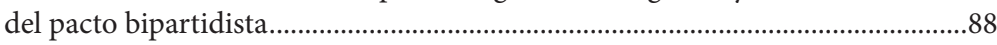

1.6. La caída de Rojas Pinilla y la legitimación del pacto bipartidista

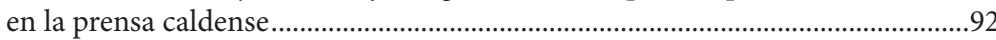

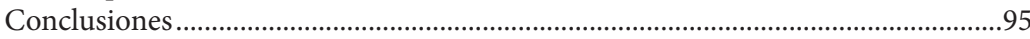

\section{CAPÍTULO DOS.}

La pacificación entre la nación y la región: discursos y propaganda periodística del coronel Gustavo Sierra Ochoa, gobernador militar de Caldas (1953-1956)

2.1. El poder militar como senda para retomar el camino de la convivencia y la paz

2.2. El Binomio y la Tercera Fuerza en marcha.................................................. 123

2.3. El Binomio durante la etapa de Daniel Cuervo Araoz.................................... 134

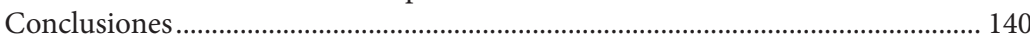

\section{CAPÍTULO TRES.}

Un acercamiento a la Acción Cívico Militar (ACM) en el departamento de Caldas (1953-1964)

3.1. Presencia bandoleril y primeros años del Gobierno militar en

Caldas

3.2. «Caldas volverá a ser modelo»: la Gobernación de Gerardo

Ayerbe Chaux.

3.3. 1964: entre el exterminio de la violencia bandoleril y el surgimiento de la guerrilla comunista 


\section{CAPÍTULO CUATRO.}

Bandidos y campesinos. La Banda del Negro Cadena en Belalcázar, Caldas (1958)

4.1. Una mirada cultural a La Violencia............................................................... 191

4.2. La población rural de Belalcázar en los años de La Violencia .................... 196

4.3. La Banda del Negro Cadena: jornaleros o chusmeros ................................... 201

4.4. Un pájaro, la chismografía y un hacendado liberal asediado ..................... 210

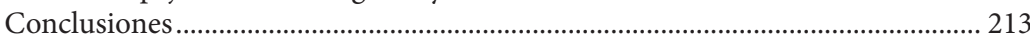

\section{CAPÍTULO CINCO.}

Gobernación militar y pacificación: el caso de Chinchiná (1953-1957)............... 219

5.1. Coronel Gustavo Sierra Ochoa: «el ánimo pacificador» en Caldas ........... 221

5.2. Acciones y cambios político-administrativos: creación de la Junta Patriótica Auxiliar y el «Consejo Administrativo» de Chinchiná .................................. 226

5.3. Los consejos administrativos .................................................................... 233

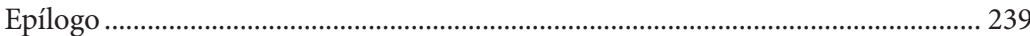

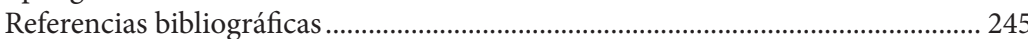

\section{ÍNDICE DE FIGURAS}

Figura nro. 1. Mapa del departamento de Caldas....................................................25

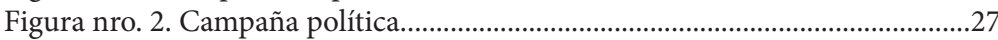

Figura nro. 3. Áreas de violencia en Caldas 1948-1953 ..........................................33

Figura nro. 4. Organización de la autodefensa.....................................................42

Figura nro. 5. Infografía: gobernadores militares en Caldas entre 1953-1967....53

Figura nro. 6. Infografía: periodizaciones de La Violencia ....................................53

Figura nro. 7. Periodización de la presencia del Ejército........................................54

Figura nro. 8. Publicidad «Caldas saluda»...............................................................64

Figura nro. 9. Portada Diario del Quindío ……………………….........................72

Figura nro. 10. Portada de El Binomio. Pueblo-Fuerzas Armadas.........................90

Figura nro. 11. Portada de la revista Semana (1953)........................................... 102

Figura nro. 12. Coronel Sierra Ochoa y Lucio Pabón Núñez Ministro de

Gobierno de Rojas Pinilla, acompañados de sus respectivas esposas .......... 106

Figura nro. 13. Manizales recibe al general Rojas Pinilla ................................... 108

Figura nro. 14. «Sucesos de ayer en Bogotá» ........................................................ 118

Figura nro. 15. Pereira adhiere y respalda al Excelentísimo Sr. Presidente Rojas

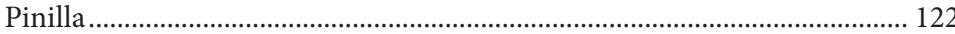

Figura nro. 16. Portada del periódico El Diario................................................... 123

Figura nro. 17. Noticia sobre el orden público en Calarcá .................................... 126

Figura nro. 18. Los enemigos del gobierno y del pueblo ...................................... 129

Figura nro. 19. Se solicita el cambio de Gobernador Militar por un Elemento

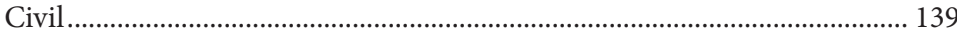

Figura nro. 20. Denuncias por infiltraciones de billetes comunistas ................. 143

Figura nro. 21. Te-Deum en acción de gracias por salida de Rojas Pinilla ...... 143

Figura nro. 22. Mapa de zonas afectadas por La Violencia 1948-1953 .............. 152

Figura nro. 23. "El Montañero" se fugó anoche del cuartel de la policía ........... 155

Figura nro. 24. Acción-cívico militar en Balboa................................................. 161 
Figura nro. 25. «Balboa da la "Batalla de la Paz"»

Figura nro. 26. Muertes violentas en departamentos afectados

por el bandolerismo: 1958,1959 y 1960 .

171

Figura nro. 27. Programa de acciones cívico- militares logradas (1962-1969).182

Figura nro. 28. Localización de la violencia en 1962 ........................................... 184

Figura nro. 29. Localización de la violencia en 1965 ............................................ 185

Figura nro. 30. Familia campesina caldense ......................................................... 197

Figura nro. 31. El cañón del río Cauca en Belalcázar........................................ 210

Figura nro. 32. Chinchiná, la ciudad luz de Colombia ...................................... 223

Figura nro. 33. Institución Educativa Santa Teresita Chinchiná 1950 .............. 231

Figura nro. 34. Desfile del Colegio Bartolomé Mitre Chinchiná, años 50 ....... 233

\section{ÍNDICE DE TABLAS}

Tabla nro. 1. Totales de delitos por secciones del país 1955-1959. 



\section{Introducción}

El sino de Caldas en cuanto a la violencia ha sido paradójico, porque es el departamento colombiano que goza, aparentemente, del más alto nivel de vida. Allí, según los sociólogos, se ha desarrollado una verdadera clase media rural que tuvo su origen en las inmigraciones de antioqueños al Quindío [sic] desde mediados del siglo XIX. Una mentalidad de empresa con un sentido de independencia ha hecho de Caldas una región próspera.

Pero quizás su riqueza [...] sea la causa de su desgracia. Los explotadores del café, en su mayoría minifundistas, han debido sufrir el impacto de la confusión causada por el robo y el ansía de tierras. Sus fértiles montañas se han visto así manchadas de sangre, y sus habitantes no han podido resolver el problema económico que los lleva a la violencia ${ }^{1}$.

La Violencia es, en primer lugar, una yuxtaposición de violencias irreductibles ${ }^{2}$.

En el presente libro se compendian algunos de los primeros resultados del proyecto de investigación «Botas para salvar la democracia en la Gobernación de Caldas, 1953-1967» avalado por la Vicerrectoría de Investigaciones, Innovación y Extensión de la Universidad Tecnológica de Pereira. El objetivo inicial de dicha investigación consistía en "Analizar el contexto histórico y las razones políticas que dieron lugar al nombramiento de militares

1 Germán Guzmán Campos, Orlando Fals Borda y Eduardo Umaña Luna, La Violencia en Colombia, t. 1 (Bogotá: Prisa Ediciones, 2012), 148.

2 Daniel Pécaut, Orden y violencia. Evolución sociopolítica de Colombia entre 1930 y 1953 (Bogotá: Editorial Norma, 2001), 554. 
como gobernadores en el departamento de Caldas entre 1953 y 1967, y sus posteriores actos político-administrativas relacionados con el orden público durante sus respectivos mandatos».

Bajo estas premisas, buscábamos subsanar el vacío historiográfico el cual ha perdurado a lo largo de estas décadas, a pesar de que algunos estudios previos han mostrado que el denominado "Departamento Modelo de Colombia» ${ }^{3}$, fue uno de los más afectados en sus principales centros urbanos Manizales, Pereira y Armenia-, así como en las zonas rurales y en las cabeceras municipales por una diversidad de situaciones de violencia bipartidista, lo que sin duda motivó el nombramiento de gobernadores militares en la región para restablecer el orden público y la paz.

De acuerdo con Carlos Miguel Ortiz, el antiguo departamento de Caldas alcanzó la cifra más alta de muertes de todo el país entre 1946 y 1957 con un total de 42805 homicidios $^{4}$, seguido por Tolima y Antioquia con 29926 y 25278 asesinatos, respectivamente. Según este mismo estudio, la región de Caldas fue una de las más afectadas por la violencia ejercida por los grupos de bandoleros entre los años 1958 y 1964, con un total de 3299 muertes, solo superada por los departamentos de Valle con 4574 muertes y Tolima con 4404 víctimas mortales, lugares con los que, dicho de paso, comparte fronteras geográficas ${ }^{5}$.

Para el caso del proyecto planteado, la búsqueda de la información se concentró, en gran medida, en el periodo presidencial del general Gustavo Rojas Pinilla (1953-1957), quien tras el golpe de Estado al Gobierno de Laureano Gómez

3 Ricardo de los Ríos Tobón, «Las diez ciudades de Manizales», Papel Salomón, acceso el 29 de mayo de 2020 https://www.lapatria.com/especiales/papel-salmon/historia/las-diez-ciudades-demanizales-325585.

4 Carlos Miguel Ortiz, Estado y subversión. La Violencia en el Quindío Años 50 (Bogotá: Fondo Editorial Cerec, 1985), 377. Las cifras que Ortiz presenta son tomadas a su vez del estudio de Paul Oquist, Violence, Conflict and Politics (Bogotá: Universidad de los Andes, copia mimeografiada, 1976).

5 Ortiz, Estado y subversión, 381. 
- en cabeza del designado a la presidencia Rafael Urdaneta Arbeláez- empezó a nombrar gobernadores y alcaldes militares para departamentos como Antioquia, Santander, Boyacá, Tolima, Valle del Cauca y Caldas. Cabe señalar que durante la época de La Violencia, los Gobiernos militares en este último se iniciaron, en una primera etapa, con el coronel Gustavo Sierra Ochoa del 24 de septiembre de 1953 al 29 de septiembre de 1956, el coronel Daniel Cuervo Araoz del 29 de septiembre de 1956 al 12 de mayo 1957, y el coronel Gerardo Ayerbe Chaux del 12 de mayo de 1957 al 29 de agosto de 1958; quienes fueron nombrados directamente por la Junta Militar que depuso a Rojas Pinilla al coincidir también con el inicio del Frente Nacional (1958-1974); lo cual supuso el fin de la Dictadura y el retorno de la democracia de las autoridades civiles y de la aparente normalidad institucional. En una segunda etapa fueron nombrados gobernadores el coronel José Gregorio Sánchez Ordoñez del 6 de noviembre de 1965 al 4 de marzo de 1966 y el general Armando Vanegas Maldonado del 4 de marzo de 1966 al 9 de septiembre de 1967. A estos les correspondió hacer la transición política para la desmembración del Viejo Caldas y la creación de los nuevos departamentos de Quindío (1966) y Risaralda (1967).

Durante el desarrollo de esta investigación se visitaron varios archivos regionales y nacionales. Respecto a los primeros se consultaron los archivos de las Alcaldías de Pereira, Manizales, Anserma, Chinchiná y Neira; así como los de la Gobernación de Caldas, el Archivo Judicial de Anserma y las hemerotecas de la Biblioteca Municipal de Pereira y de las áreas culturales del Banco de la República de Pereira, Armenia y Manizales. Igualmente, se visitaron el Archivo General de la Nación para revisar el fondo del Ministerio de Gobierno y la hemeroteca de la Biblioteca Nacional. Una observación necesaria respecto a la documentación revisada y recolectada a nivel regional tiene que ver con la falta de catálogos, además de los vacíos temporales que presentan estos acervos de documentos, lo cual demuestra la desorganización en que se encuentran muchos de estos archivos en la actualidad. 
Esto nos llevó en varios casos a realizar las búsquedas por indiciosyporseleccionesaleatorias, en medio degrandescantidades de documentos desorganizados, con las cuales encontramos información fragmentaria sobre temas que atañían la Dictadura de Rojas Pinilla, los Gobiernos Militares, la conformación de Juntas Patrióticas o denuncias sobre homicidios, la presencia de grupos de bandoleros y los abusos de autoridad por parte de las Fuerzas Armadas (FF. AA.). De esta forma, la documentación recopilada fue dividida en secciones de prensa regional; en documentos oficiales nacionales, departamentales, y municipales; y memorias de militares. A partir de allí, el análisis de la información se enfocó en rastrear los actos político-administrativos de los militares en el poder, prestando especial atención a los relacionados con el orden público y el desarrollo de programas de asistencia social.

Esta selección del material archivístico influyó en el desarrollo de los capítulos del presente libro. Además de destacarse el uso de documentos no evaluados anteriormente y que permiten mostrar el comportamiento político de la Dictadura en una escala regional y local, también posibilitó abordar los Gobiernos militares desde distintas temáticas de investigación. De este modo, lo que se pierde en términos de establecer una sola línea investigativa, se gana en la diversidad de temas y perspectivas, presentes en cada uno de los capítulos. Consideramos que con los apartados ofrecidos en este libro hemos logrado presentar una visión histórica de conjunto acerca de la violencia, la democracia y la dictadura en el contexto regional, lo mismo que sobre el papel de la prensa y sus múltiples referencias con respecto a la campaña de pacificación y la acción cívica-militar desplegada por los agentes del Ejército en la región de Caldas durante buena parte de la década de los años cincuenta y los primeros años de la década de los años sesenta.

A pesar de haber delimitado el texto a unos temas específicos, es indudable que sigue siendo bastante complejo dar cuenta de la dinámica política, los hechos de violencia y del vaivén de las opiniones políticas registrados en los periódicos conservadores 
(La Patria 1921 y El Diario del Quindío 1928), liberales (El Diario 1929), y otros más que defendieron la causa de los gobernadores militares (El Binomio 1956). A lo anterior se suma la dispendiosa tarea de hilar las múltiples interconexiones entre la escala regional, nacional e incluso internacional, en un período donde adquirieron bastante preponderancia los procesos de modernización vía estatal en América Latina y que también tenían como correlato las tensiones geopolíticas entre la Unión de Repúblicas Socialistas Soviéticas (URSS) y los Estados Unidos (EE. UU) ${ }^{6}$.

Hay que tener presente la situación política que el país vivía bajo condiciones poco democráticas a mediados de los años cincuenta: permanecía vigente la declaratoria del estado de sitio desde finales del año 1949, había censura de prensa, el Congreso de la República estaba clausurado, lo mismo que las Asambleas Departamentales y los Concejos Municipales. El presidente Laureano Gómez pretendía ir mucho más allá al limitar el sufragio popular y al crear una cámara corporativa en el Congreso - que estuviera compuesta por los gremios, la Iglesia, los sindicatos y los estudiantes universitarios, los cuales eran nombrados por el mismo presidente- . Los gobernantes de turno de aquellos años apelaban a esta figura de excepción al reivindicar el orden por encima de ciertas libertades públicas y del estado de derecho ${ }^{7}$. En la presidencia de Rojas Pinilla se aprobó el Acto Legislativo Nro. 2, de diciembre 13 de 1954, el cual reformaba una vez más la Constitución Nacional y ratificaba la figura de la Asamblea Nacional Constituyente. Unos meses antes, en octubre 29 de 1954, Rojas emitió el Decreto presidencial 3170 de 1954, por el cual reglamentaba el funcionamiento de los consejos administrativos departamentales y municipales. En estas condiciones, se ejerció

6 En las teorías de la modernización que se imponían desde agencias multilaterales norteamericanas, «...el papel del ejército en la preservación de cierto orden (las "instituciones libres" o enemigas del comunismo) era esencial, y para ello debería tomar parte también en las reformas que se percibían como necesarias para avanzar en las etapas de crecimiento económico». Daniel Castro Morales, «Modernización contrainsurgente: la acción cívico militar en Colombia y sus fuentes intelectuales (1958-1971)» (Trabajo de grado, Universidad de Antioquia, 2016), 29.

7 Álvaro Tirado Mejía, «El gobierno de Laureano Gómez. De la dictadura civil a la militar». En Nueva Historia de Colombia, t. 2, ed. por Jorge Orlando Melo (Bogotá: Editorial Planeta, 2001), 83. 
hasta 1958 la gobernabilidad en el país bajo el pretexto de disminuir la beligerancia entre los partidos políticos y salvar las instituciones públicas de toda suerte de sectarismos políticos.

De igual modo, el Ejército quiso apaciguar este estado de turbulencia política al intervenir en distintas regiones del país mediante la acción cívico-militar, así como con la concesión de amnistías a bandoleros y guerrilleros. Pero el ambiente de conflictividad y de exaltación de las pasiones partidistas se mantenía a pesar de las infructuosas medidas de paz. Al cabo de unos años, este pacificador se vio inmerso en la dinámica conflictiva del momento: por un lado, atacó a la oligarquía y a los partidos políticos en una clara reproducción del país político presente en el discurso de Jorge Eliécer Gaitán. Por otra parte, arremetió visceralmente contra el comunismo - desde los albores de la Guerra Fría-. A pesar de defender y querer establecer un pacto político indisoluble con el pueblo, a través de la denominada Tercera Fuerza, el Ejército le reprochaba al mismo pueblo su falta de educación cívica, la poca colaboración con las Fuerzas Armadas y los atavismos culturales que sumía a la mayoría de la población analfabeta en el apego irrestricto al caciquismo político.

En este sentido, el fin del régimen militar se vio marcado por el establecimiento del pacto consociacionalista, entre los dos partidos tradicionales, llamado Frente Nacional. Con él, se estableció la distribución paritaria de todos los cargos públicos de la República como mecanismo para superar la violencia partidista. Esta "pasmosa innovación», como la denomina Guillén Martínez, estuvo marcada a su juicio por la renuncia de los partidos a la violencia, la enajenación total de la representación política del país por parte de liberales y conservadores, y la influencia de los gremios a nivel estatal ${ }^{8}$. De esta forma, se estableció un estado clientelista con la capacidad de movilizar importantes recursos económicos de forma específica a las redes clientelares en cada departamento del país ${ }^{9}$. Según lo anterior, el periodo del frente

8 Fernando Guillén Martínez, El poder político en Colombia (Bogotá: Ariel, 2015), 440-441.

9 Francisco Leal Buitrago, Estado y política en Colombia (Bogotá: Siglo xxi Editores, 1989), 317. 
nacionalista ha sido tildado, por ejemplo, como una «democracia restringida» ${ }^{10}$ que, aunque no llegó a tener el autoritarismo de otros países latinoamericanos, se distinguió por el inmovilismo de la rama legislativa, la falta de respuestas a las demandas populares y la exclusión de nuevos movimientos políticos por fuera de los dos partidos tradicionales, incluso llegando a hacer uso del fraude electoral ${ }^{11}$.

Por tal motivo, consideramos que puede ser útil realizar la reducción de la escala de observación para llevar a cabo el análisis de la violencia a nivel regional. Al poner la lupa sobre una serie de hechos circunscriptos a la región caldense, tratamos de establecer una conexión de ida y vuelta entre la variación regional y la dinámica nacional, o como señala Marco Palacios, asumimos la necesidad de «...entender la cuestión regional como un problema nacional» ${ }^{12}$.

En este orden de ideas, es necesario realizar una contextualización de las principales tendencias económicas, políticas y sociales del departamento de Caldas a mediados del siglo $\mathrm{xx}$, con el fin entender ciertas tensiones y rivalidades que existían entre algunos de los principales centros urbanos de la región respecto a la capital, es decir, Manizales; y las implicaciones en las dinámicas políticas de la región. Es claro que, la violencia bipartidista fue uno de los argumentos más fuertes utilizado para retroalimentar el animus belli ${ }^{13}$ intrarregional que llevaría a la postre a la desintegración territorial del, hasta entonces, departamento modelo de Colombia.

10 Daniel Pécaut, Crónica de dos décadas de política colombiana 1968-1988 (Bogotá: Siglo Xxı Editores, 1988), 18.

11 Jonathan Hartlyn, La política del régimen de coalición. La experiencia del Frente Nacional en Colombia (Bogotá: Tercer Mundo Editores, 1993).

12 Herbert Braun, «De palabras y entendimientos del comportamiento cotidiano entre los colombianos durante La Violencia de los años cincuenta». En La restauración conservadora 1946-1957, ed. por Rubén Sierra Mejía (Bogotá: Universidad Nacional de Colombia, 2012), 23.

13 El animus belli representa «...el mantenimiento de la hostilidad como horizonte abierto para dirimir las tensiones y los conflictos propios del mundo social y la violencia como estrategia para la solución de los problemas de la vida en común». María Teresa Uribe, «Las soberanías en disputa: ¿conflicto de identidades o de derechos?», Revista Estudios Politicos, n. ${ }^{\circ} 15$ (1999): 26. 
Así, con el fin de ubicar al lector en las coordenadas históricas en las cuales se enmarcan los capítulos que conforman este trabajo, es pertinente realizar un breve balance historiográfico que permita sopesar los estudios hechos sobre la violencia a nivel regional. De este modo, se presentan algunos referentes historiográficos, los cuales han servido de base para entender, por un lado, las dinámicas políticas y electorales; y por otro, los textos analizados que también ofrecen una valiosa información sobre la presencia de grupos armados como los pájaros conservadores, la chusma liberal, los bandoleros; e incluso, el rumor creciente de la presencia de las primeras organizaciones guerrilleras de orientación marxista confundidas con formas de autodefensa campesina. Cabe señalar que en algunos de estos textos también se analiza el papel de las Fuerzas Militares en los procesos de pacificación en la región, lo mismo que su paulatina y creciente injerencia en hechos de violencia y abusos de autoridad contra la población civil.

Por último, consideramos pertinente hacer un breve acercamiento a cierta bibliografía centrada en el análisis del papel del Ejército colombiano durante el periodo de estudio. Particularmente, nos interesa evidenciar los debates y las transformaciones de la institución militar durante los años de La Violencia, la Dictadura militar de Rojas Pinilla y los primeros años del Frente Nacional, todo ello en el marco contextual de la Guerra Fría, la lucha anticomunista y las estrategias de seguridad continental direccionadas por los sucesivos Gobiernos de los Estados Unidos que, como se sabe, fueron adaptadas al contexto del conflicto armado en Colombia desde la década de los años 60 .

\section{Sobre la región}

El departamento de Caldas fue creado durante la administración del general Rafael Reyes mediante la Ley 17 del 11 de abril de 1905. Tras una serie de vaivenes administrativos y disputas políticas intrarregionales, alcanza su conformación 
definitiva en el año 1912. En la nueva jurisdicción territorial se incorporaron ciudades y poblados de muy vieja data producto de la etapa colonial española, al igual que una miríada de pueblos que se formaron en diversos procesos colonizadores en los antiguos Estados Soberanos del Cauca, del Tolima y de Antioquia desde mediados del siglo xIx. El balance historiográfico regional hecho por Ortiz plantea cómo la conformación histórica del territorio, que actualmente ocupan los departamentos de Caldas, Risaralda y Quindío, integró cinco subregiones o «países» distintos, cada uno con dinámicas particulares de acuerdo con variables geográficas, sociales, económicas y culturales ${ }^{14}$. Razón por la cual, a pesar del peso histórico que tiene la colonización antioqueña, se trata de una región con una gran diversidad cultural, en gran medida por su importante ubicación geográfica en pleno centro occidente del país - con límites al norte con Antioquia, al occidente con Chocó, hacia el sur occidente con el Valle del Cauca y hacia el oriente con Cundinamarca y Tolima-. Lo anterior ha dado lugar a que circulen por dicho espacio y se relacionen de manera muy disímil personas de diversos grupos étnicos, culturales y regionales, incluidas algunas colonias extranjeras de alemanes, franceses, sirios y libaneses. De igual manera, a lo largo de la historia se han remarcado ciertas diferencias entre los modos de vida a nivel rural y urbano, lo mismo que el enfrentamiento entre el mundo rústico campesino y los valores de vida modernizantes de los principales centros urbanos de la región, entre los que se cuenta la capital, a saber, Manizales, al igual que Pereira y Armenia (fundadas en 1849,1863 y 1889 , respectivamente).

Desde comienzos del siglo xx, tras el final de la Guerra de los Mil Días, esta región se caracterizó a nivel nacional por el empuje de su economía cafetera, lo cualllevó a que Caldas fuera reconocido como el «departamento modelo» de Colombia, tal como se señaló anteriormente. Se puede decir que, hacia la década de los veinte

14 Luis Javier Ortiz, Lina Marcela González y Oscar Almario García. Caldas, una región antigua y nueva, tradicional y moderna, local y nacional: hacia un nuevo siglo XIX del noroccidente colombiano. Balance bibliográfico de Antioquia, Caldas y Chocó, t. 2 (Medellín: Universidad Nacional de Colombia, 2015), 23. 
del siglo pasado, se había logrado consolidar un moderno sistema de transportes, el cual permitió dar un salto histórico de la mula y la arriería, al cable aéreo, el tranvía, el ferrocarril, las carreteras entre los principales centros urbanos, los servicios públicos y bancarios, entre otros ${ }^{15}$. A pesar de su corta extensión territorial —de 14305 kilómetros cuadrados, lo que representaba el 1.21 $\%$ de la superficie total de Colombia-, se demostraba «la lejana relación existente entre la extensión territorial» y el desarrollo económico efectivo de la región y sus gentes ${ }^{16}$.

Otro aspecto que ayuda a comprender los acelerados procesos de cambio económico y sociocultural en la región tiene que ver con el auge de asociaciones voluntarias cívicas y comerciales que, junto a los cabildos municipales, promovieron los ideales de progreso y civismo característicos de aquellos años, al tratar de armonizar el progreso material de las urbes con el «progreso espiritual» de sus habitantes, consistente en la promoción de las «buenas costumbres», la higiene y la moral pública; al igual que la regulación de la vida social por medio de la Iglesia católica ${ }^{17}$.

Ahora bien, una muy buena forma de entender ciertas dinámicas demográficas de la región puede ser a través del ejercicio comparativo de los censos de 1938, 1951 y 1964. Durante estos años, la región fue escenario de múltiples procesos a nivel socioeconómico, los cuales pusieron en cuestión el proyecto modernizador caldense. Es evidente que luego de haber superado los efectos de la crisis económica de los años treinta a nivel mundial, el monocultivo del café empezó a atravesar por ciclos productivos y caídas de precios, los cuales afectaron las finanzas de los grandes exportadores y dueños de trilladoras, así como de los pequeños y medianos productores del grano. También se vivió un intenso proceso de migración campo-ciudad motivado, en parte,

15 Antonio García Nossa, Geografia económica de Caldas. (Bogotá: Banco de la República, 1978), XI.

16 García Nossa, Geografia ..., 49.

17 Jhon Jaime Correa, Civismo y educación en Pereira y Manizales. (1925-1950): análisis comparativo entre sus sociabilidades, visiones de ciudad y cultura cívica (Pereira: Universidad Tecnológica de Pereira, 2014), 149. 
por la industrialización y el auge de los modos de vida urbana, incrementados a finales de las décadas de los años cincuenta y sesenta, como consecuencia de la violencia bipartidista que afectó las zonas rurales de este departamento.

En efecto, para el censo nacional de 1938, el departamento de Caldas registró una población de 769968 habitantes, ocupando el tercer lugar a nivel nacional, por detrás de Antioquia (1 188 587 habitantes) y Cundinamarca (1 174607 habitantes), en un momento en el que Colombia contaba con una población de 8 701816 personas. Entre los factores que explicaban el crecimiento poblacional en Caldas se citaban las altas tasas de natalidad y los movimientos migratorios producidos en el interior del país ${ }^{18}$.

El incremento de la población era constante y creciente. Además del café, se debe referenciar el impulso que habían alcanzado algunos sectores industriales (textiles, bebidas, alimentos, entre otros), el comercio, la minería, la ganadería, los transportes, el auge de ciertas profesiones liberales (médicos, abogados, ingenieros, contadores, agrónomos, periodistas, entre otros); a lo que se suma el alto número de personas vinculadas a los entes estatales en áreas de salud, de instrucción pública, de rentas, de obras públicas, entre otras.

Según la información censal de 1938, la capital departamental registraba 86027 habitantes, mientras que Pereira y Armenia habían llegado a 60492 y 50838 habitantes respectivamente. No obstante, según el mismo censo, es llamativo observar que para esa época la mayoría de la población del departamento habitaba las zonas rurales (522 981 personas), comparados con los 246987 residentes en las principales zonas urbanas. Más adelante se verá cómo se rompe paulatinamente esta relación entre lo urbano y lo rural.

18 Contraloría General de la República, Censo general de población 1938, departamento de Caldas (Bogotá: Editorial Minerva, 1941), 6. 
Desde esa época se notaba que el departamento tenía las tasas de analfabetismo más bajas de todo el país: $30.5 \%$ sobre el total de la población mayor de 7 años, por encima de Antioquia (32.6\%) y Valle del Cauca $(33.5 \%)^{19}$.

A pesar de los llamativos datos de desarrollo económico, crecimiento poblacional y superación del analfabetismo, el estudio de García —realizado en el año 1937-, también da cuenta de la precariedad de las condiciones de vivienda, salubridad y alimentación de muchas familias campesinas. Se señalaba, en particular, la carencia de un sistema de organización sanitario eficaz que le permitiera hacer frente a enfermedades características de la región como la anemia tropical, el paludismo, la sífilis, las venéreas y la tuberculosis. Contrastaban las profundas diferencias en cuanto a calidad de vida en las principales ciudades, en comparación con municipios como Mistrató, Pueblorrico - al occidente de Caldas, en límites con el Chocó, donde habitaban grupos étnicos de población afrodescendiente e indígenas de los diferentes resguardos Emberá Chamí-,Marmato - al norte del departamento, con un fuerte predominio de la población afrodescendiente dedicada a las labores ancestrales de la minería-, y las zonas húmedas selváticas de municipios como La Victoria, Marquetalia, Samaná, entre otros, que no contaban siquiera con un médico graduado para atender la población ${ }^{20}$.

Hacia el año 1951, Caldas había incrementado su población a 1068180 habitantes (546 472 hombres y 521708 mujeres). En esta ocasión, ocupaba el cuarto lugar detrás de Cundinamarca (1 624 444 habitantes), Antioquia (1 570197 habitantes) y Valle del Cauca (1 106927 habitantes). Cabe decir que, a principios de los años cincuenta, Colombia contaba en total con 11548172 de personas. A partir del censo de población de 1951, se empezó a observar que la población radicada en zonas urbanas tendía a emparejar el número de personas en el campo — 406 747 en cabeceras y 661

19 Contraloría General de la República. Censo general..., 7.

20 García Nossa, Geografía..., 219. 
433 en zonas rurales- ${ }^{21}$. De hecho, las tres principales ciudades seguían incrementando su población: Manizales alcanzó la cifra de 126201 habitantes, mientras Pereira y Armenia registraron 115 342 y 78380 habitantes respectivamente. De igual modo, las tasas de analfabetismo habían descendido a un $23 \%$ de la población ${ }^{22}$.

A mediados de los años sesenta, Caldas ascendió a 1455872 habitantes y se convirtió nuevamente en el cuarto departamento del país en cuanto a población. En ese momento, Colombia contaba con 17484508 habitantes. Sin embargo, resulta muy llamativo observar que, en ese año, por primera vez en la historia demográfica de la región, la población radicada en las cabeceras (817 432 personas) era mayor que la que residía en las zonas rurales (688 440 personas). De igual modo, es necesario señalar que las moradoras femeninas llegaban a 727039 mujeres, una cifra muy cercana a los 728833 hombres censados en todo el departamento. Esta situación de género es más llamativa si se observa en las tres principales ciudades de la región: Manizales contaba con 221 916 habitantes, de los cuales 109167 eran hombres y 112749 mujeres; Pereira tenía 188365 habitantes, 90925 hombres y 97 840 mujeres; y Armenia tenía 137222 habitantes, 67345 hombres y 69877 mujeres $^{23}$. Estos datos son relevantes en tanto revelan la preponderancia de las mujeres en los procesos de cambio sociodemográfico y económico a nivel de los tres principales centros urbanos de la región.

Otro aspecto bastante significativo de este censo es que para tratar de estimar el número de migrantes recién llegados a cada una de las principales ciudades del departamento de Caldas, se les preguntó a las personas censadas cuántos habían nacido en el mismo municipio. Los resultados fueron los siguientes: Manizales $=128368$ personas $(57 \%)$; Pereira $=88323$ personas $(46 \%)$;

21 Departamento Administrativo Nacional de Estadística (DANE), Censo nacional de población 1951. Caldas (Bogotá: DANE, 1951), 10.

22 Departamento Administrativo Nacional de Estadística (DANE), Censo nacional..., 38.

23 Departamento Administrativo Nacional de Estadística (DANE). XIII censo de población y II de edificios y viviendas. Julio 15 de 1964. Caldas (Bogotá: DANE, 1964), 25-33. 
y Armenia $=65706$ personas $(47 \%)$. Lo anterior da cuenta del profundo proceso de migración campo-ciudad, el cual se había generado durante estos años y que constituyó a estas ciudades en receptoras de «exilados» de la violencia, como se decía en aquellos tiempos ${ }^{24}$.

Es precisamente a partir de este periodo que se acentúan las diferencias y las rivalidades entre los grupos de poder de los centros urbanos de Armenia y Pereira respecto a la dirigencia y la clase política manizalita, las cuales trajeron como consecuencia la separación y la posterior creación de los departamentos de Quindío (1966) y Risaralda (1967). El inconformismo político que motivó los movimientos separatistas venía desde tiempo atrás, casi desde el inicio de la creación del departamento de Caldas en 1905. Sin duda, ciertos aspectos relativos a la descentralización políticoadministrativa tuvieron un gran peso, así como el malestar por lo que desde las provincias se consideraba como onerosas cargas tributarias no redistribuidas de manera equitativa en el desarrollo de las distintas municipalidades que integraban el departamento. En muchas de estas zonas empezó a circular un reclamo, en diversos espacios públicos y privados, bajo la consigna de rechazar a como diera lugar el «...asfixiante centralismo de Manizales» ${ }^{25}$.

Tales disputas reforzaban las aspiraciones hegemónicas de las familias más notables de cada ciudad, así como la intensa presión de las elites empresariales por alcanzar una mayor autonomía presupuestal. Lo anterior se reforzaba con los intereses proselitistas de las clientelas políticas de ambos partidos, en cabeza de sus principales caudillos, que sin duda deseaban tener un mayor control sobre los cargos burocráticos, la inversión de los recursos cafeteros y el erario proveniente del Estado Nacional ${ }^{26}$.

24 Departamento Administrativo Nacional de Estadística (DANE). XIII censo de población..., 48-52.

25 Jairo Antonio López y Jhon Jaime Correa, «Disputas por la centralización/descentralización administrativa en el Viejo Caldas, 1905-1966: los casos de Manizales y Pereira» Anuario Colombiano de Historia Social y de la Cultura 39, n. 2 (2012): 207; Ver también: Edwin Mauricio López y Jhon Jaime Correa «Historia de una ley. Ley 70 de diciembre 1 de 1966, "por la cual se crea el departamento de Risaralda"». Reflexión Política 22, n. ${ }^{\circ} 4$ (2020): 40-53.

26 García Nossa, Geografia..., XI. 
Además de los apetitos clientelares y burocráticos que motivaron el agitado proceso político, social y legislativo, el cual derivó en la creación de los nuevos departamentos, también se apeló —en no pocas ocasiones - al argumento de que la separación contribuía a la pacificación de la región que estaba inmersa en La Violencia. Particularmente, se arguyó la necesidad de zanjar las diferencias casi existenciales entre la capital ultraconservadora y dos ciudades progresistas de provincia, de corte más liberal, como Pereira y Armenia.

Para concluir este sub-acápite, es necesario decir que no se encuentran muchos estudios los cuales indaguen por el desenvolvimiento regional de cada uno de los departamentos luego del fraccionamiento político administrativo de Caldas a finales de los años sesenta. Según García, la separación afectó la capacidad de negociación del antiguo Caldas. En la segunda edición de su libro Geografía económica de Caldas, publicada en el año 1978, señalaba que el clientelismo político, «...desatado por el funcionamiento de tres aparatos burocráticos departamentales, ha conducido a la pérdida de una perspectiva nacional del problema caldense y ha consagrado la victoria pírrica de los intereses y criterios y valores localistas provincianos» ${ }^{27}$.

Y como la historia está hecha con base en una serie de paradojas las cuales se repiten en el tiempo - primero como tragedia y luego como comedia, diría $\mathrm{Marx}^{28}$-, hoy, tras más de cinco décadas de separación, entre las tres unidades políticoadministrativas departamentales independientes ha resurgido la necesidad de implementar nuevas estrategias de desarrollo conjunto, mediante la implementación de la figura de la región administrativa y de planeación, que según lo define la Federación Nacional de Departamentos, son:

27 García Nossa, Geografía..., XIII.

28 Karl Marx, El dieciocho brumario de Luis Bonaparte (Moscú: Editorial Progreso, 1981). 
... una especie de liga o alianza establecida entre departamentos para conseguir objetivos de desarrollo común: explotar racionalmente sus recursos naturales compartidos (por ejemplo, convertir en ecoparque la zona del Volcán Nevado del Ruiz), generar proyectos de desarrollo en áreas específicas y establecer, entre otras muchas opciones, negocios a partir de la construcción de infraestructura en común ${ }^{29}$.

Han sido varios los encuentros realizados con bombos y platillos, en los cuales se ha señalado que los odios del pasado deben quedar atrás en función de trabajar conjuntamente, en los próximos dieciseis años, en temas de innovación y competitividad, sostenibilidad ambiental, desarrollo humano, turismo y paisaje cultural cafetero, entre muchos otros frentes de trabajo ${ }^{30}$.

29FederaciónNacionaldeDepartamentos, «QuéesunaRAP», acceso29demayode2020,https://fnd.org.co/ fnd/index.php?option=com_content\&view $=$ article $\&$ id $=4489 \&$ catid=21\&Itemid $=233 \#: \sim:$ text=LA $\% 20$ RAP\%20(Regi\%C3\%B3n\%20Administrativa\%20y,del\%20Ruiz)\%2C\%20generar\%20proyectos\%20 de.

30 La Crónica del Quindio. «RAP Eje Cafetero construye plan con visión a 16 años», 14 de febrero de 2020. https://www.cronicadelquindio.com/noticia-completa-titulo-rap-eje-cafetero-construye-plan-convision-a-16-anos-cronica-del-quindio-nota-136662.htm. 
Figura NRo. 1. Mapa del departamento de Caldas.

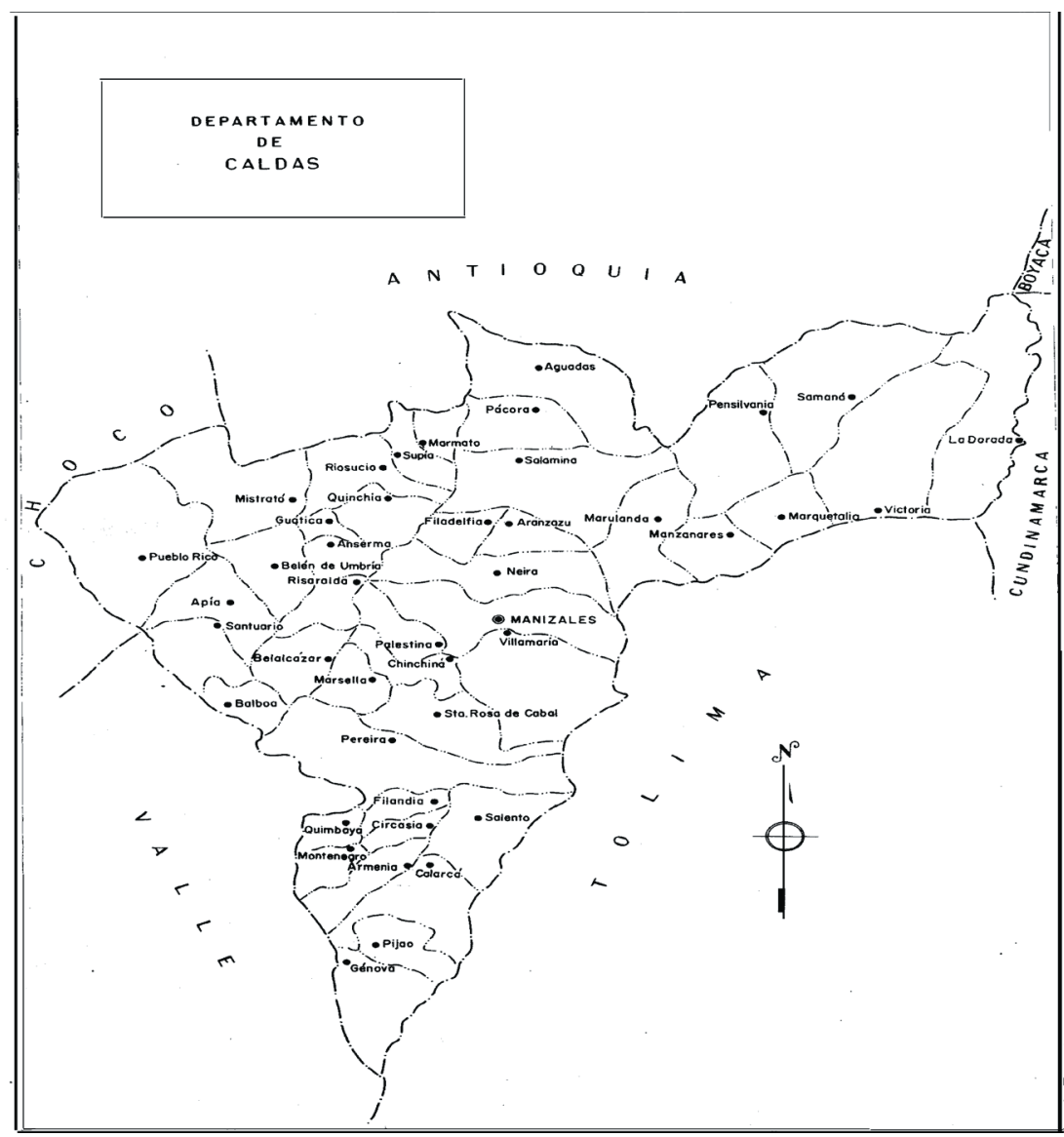

Fuente: Departamento Administrativo Nacional de Estadística (DANE), Censo nacional de población, 1951. Caldas.

Sobre la violencia a escala regional en Caldas

¿Por qué era necesaria la pacificación en esta región? ¿Qué dimensión alcanzaron los fenómenos de violencia política en la región de interés entre 1946 y 1964? ¿Cómo se caracterizaba esta violencia a nivel de las colectividades políticas y cómo afectó la tranquilidad de las familias, el patrimonio económico de 
ciertas personas y el orden público en las diferentes subregiones del departamento? Incluso, cabe extender la reflexión hacia los filtros simbólicos partidistas que establecían los diferentes actores políticos y sociales, entre los hechos de violencia y la representación de los mismos, para dar cuenta de cómo La Violencia permitió relacionar hechos de sangre, amenazas, agresiones, desplazamientos forzados contra individuos y familias enteras, entre otros; con ese otro ámbito de los rumores, los chismes, las representaciones del miedo, las justificaciones sobre el uso de la violencia y, por supuesto, con los códigos de los lenguajes políticos de la época. Insistimos en la necesidad de hacernos este tipo de preguntas, con el fin de explicar las múltiples conexiones entre la política local y la nacional, así como con el peso de ciertos regionalismos en la intensificación de las rivalidades políticas de antaño ${ }^{31}$.

Algunos textos consultados sobre la violencia en la región del Viejo Caldas dan cuenta de los fenómenos de gamonalismo y caciquismo; su importancia en la vida pública de los centros urbanos y los pequeños poblados en la región; la red de lealtades políticas que derivaron en sectarismos de diferente signo respecto al opositor político; el papel de la Iglesia católica y la presencia de grupos de pájaros conservadores, guerrilleros liberales, bandoleros y organizaciones de orientación marxista. El acumulado investigativo también da cuenta, en menor medida, del papel que cumplió el Ejército en la zona durante los años de La Violencia, específicamente sobre su accionar cívico-militar, aunque sin haber logrado la producción de una obra mayor sobre estos fenómenos.

En el contexto de la producción historiográfica sobre la violencia política en el país, resalta la peculiaridad del caso caldense en términos de su perfil socioeconómico y demográfico que, como se dijo en el anterior apartado, representó el segundo

31 Keith H. Christie, Oligarcas, campesinos y politica en Colombia: aspectos de la historia sociopolitica de la frontera antioqueña (Bogotá: Universidad Nacional de Colombia, 1986), 121. 
departamento más pequeño de Colombia con las mayores tasas de población alfabetizada, donde se aportó el $8.4 \%$ de la población total del país y fue la tercera o cuarta región con mayor potencial económico. A pesar de estas condiciones, o quizás debido a ellas, Caldas tuvo el $26 \%$ de las víctimas de la violencia política partidista.

Figura NRo. 2. Campaña política.

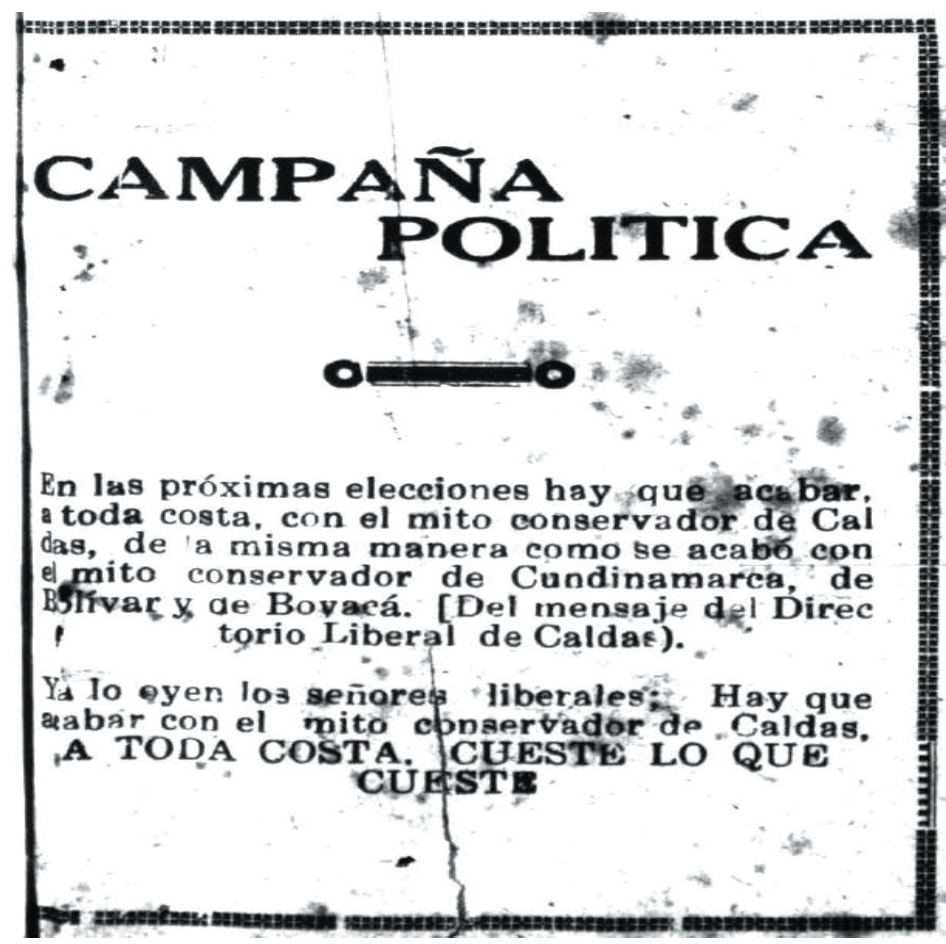

Fuente: El Diario [Pereira], 1 de marzo de 1935.

Ahora bien, ¿qué es lo que se designa como Violencia en la época? Es mucho lo que se ha escrito en nuestro país sobre el significado y la carga simbólica que contiene este concepto cuando se le usa o se le piensa como un sustantivo, el cual ayuda a caracterizar una época específica de nuestra historia. Análisis lúcidos como los de Daniel Pécaut y Carlos Miguel Ortiz señalan 
que esta palabra encubre más de lo que logra explicar en cuanto a la dinámica conflictiva de las relaciones políticas en la Colombia de mediados del siglo xx. Al respecto, Pécaut anota:

La Violencia aparece a menudo, en las innumerables narraciones y testimonios que ha suscitado, como una potencia anónima que siembre la destrucción a su paso. En todos los casos, el término quiere expresar la irrupción en la historia de un trasfondo de barbarie ordinariamente recubierto por una aculturación precaria. No es por casualidad que las elites político-económicas lo adaptaron desde el principio. Esta denominación permite ocultar los rastros de las estrategias de violencia que una parte de estas elites promovió sistemáticamente ${ }^{32}$.

\section{Por su parte Ortiz agrega:}

... el término globalizador de La Violencia tiene la virtud de permitir recordar la historia sin atribuir responsabilidades y, claro está, sin explicarla, a no ser bajo el esquema simplificado en dónde sólo [sic] se trata de los efectos de la única y grande Causa $[s i c]$. Visión tanto más conveniente cuanto se adecúa a las nuevas circunstancias: la conciliación de los conservadores y los liberales a través del Frente Nacional, pactado en 1957; el retorno al lenguaje de la legalidad, por parte de los campesinos liberales que apoyaban las cuadrillas; en fin, la aceptación de la presencia y de la cooperación del Ejército en las zonas de guerrilla liberal ${ }^{33}$.

Como se logra ver, el debate académico y político no cesa, y la expresión permite igualmente establecer una serie de narrativas históricas que exigen un análisis profundo, sobre todo cuando se tiende a instrumentalizar su uso para remarcar periodos de ruptura, de transición, de fundación de un nuevo orden social o, simplemente, de vuelta a la democracia. Es evidente que ciertas formas de acción política violenta, esto es, aquella en las cuales

32 Daniel Pécaut, Orden y violencia. Evolución sociopolítica de Colombia entre 1930 y 1953

(Bogotá: Editorial Norma, 2001), 552-553.

33 Ortiz, Estado y subversión ..., 22-23. 
recurrían al asesinato, la amenaza y el constreñimiento electoral, entre otros, fueron agenciadas por las elites políticas de nuestro país.

La Violencia, expresión escrita con mayúscula, como si se tratara de un signo nefasto de la historia de Colombia, estuvo cargada por la exaltación de las rivalidades políticas de liberales y conservadores que llevaron al exterminio de sus copartidarios en diferentes zonas del país. Como convención se suele citar la fecha exacta del 9 de abril de 1948 —el asesinato del caudillo liberal Jorge Eliécer Gaitán-, como el momento del inicio de esta especie de guerra civil no declarada. Otros prefieren ubicar el inicio de las confrontaciones en el año de 1946, a partir del retorno al poder presidencial del Partido Conservador, en cabeza de Mariano Ospina Pérez. También hay otros que extienden la periodización de La Violencia hasta el año 1930, cuando se dio el cambio de gobierno de la Hegemonía Conservadora — tras más de cuarenta años en la jefatura del Estado- a la República Liberal ${ }^{34}$.

En este inventario de viejas y nuevas intemperancias políticas en la región, cabe referenciar las hostilidades con las que se llevaban a cabo las elecciones, especialmente después de 1936, cuando se autorizó la cédula electoral y el sufragio universal entre los hombres mayores de veintiún años sin distinciones económicas, sociales o educativas. La geografía política de Caldas muestra municipios y regiones con unas claras y radicales posturas conservadoras y liberales, que en tiempo de elecciones (presidenciales y para los ejecutivos y legislativos, locales y departamentales) daban lugar a mutuos señalamientos los cuales no solo terminaban en denuncias de fraude. En las calles, plazas, cantinas, fondas y zonas rurales alejadas de los cascos urbanos se presentaban lamentables hechos de sangre e incluso masacres, como sucedió en Quinchía, Calarcá, Pijao, Victoria, Marquetalia, Pereira, entre otros ${ }^{35}$.

34 Hernando Correa Peraza, Los rostros de la violencia. Colombia 1930-1958. Historias para refrescar la memoria de los liberales y los conservadores (Bogotá: Universidad Sergio Arboleda, 2009).

35 Walter Ramírez Herrera y Martha Cecilia Jiménez, Marquetalia. La Violencia en provincia. 1946-1965 (Cali: Imprenta Departamental del Valle del Cauca, 2002). 
Dentro del mapa político se reconoce el sur de Caldas (hoy Quindío) como liberal, lo mismo que algunos municipios del occidente (Quinchía, Balboa y La Virginia) y del oriente (La Dorada) del mismo departamento. Electoralmente, hubo pueblos que pasaron de contar con mayorías liberales en los años treinta y que al parecer se "conservatizaron» después de 1946 (Santuario y Belalcázar). De resto, una buena parte de los municipios se reconocen como conservadores. Por supuesto, se cuentan las viejas rivalidades entre la capital conservadora, Manizales, con las ciudades de Armenia y Pereira predominantemente liberales. Keith Christie señala un aspecto importante al dar cuenta de la intensidad de las tensiones y la competencia electoral partidista. A través de sus análisis electorales entre 1930 y 1953, logra mostrar la situación en la cual «...el partido mayoritario rara vez [...] [recibía] más del $55 \%$ de los votos, a no ser cuando uno de los dos partidos se abstenía» ${ }^{36}$.

Sin embargo, después de 1946, fue muy notorio el proceso de conservatización de muchas zonas del departamento. Según Christie,

En el Quindío, los votantes de las poblaciones de Filandia y Pijao se pasaron de manera abrupta al conservatismo, mientras que otras ciudades como como Marquetalia y Filadelfia, vieron aumentar sustancialmente la ventaja conservadora. No obstante, el giro electoral más notable ocurrió de nuevo en el occidente. Por ejemplo, en Apía los liberales consiguieron una ligera mayoría para concejo municipal en 1945. Los conservadores ganaron nuevamente en 1947 y hacia 1958 elevaron su margen de victoria hasta una relación de 10 a 1 . Santuario, con una segura mayoría liberal en 1945, fue tomada por el conservatismo en la elección de 1949. Para 1958, los conservadores tenían una mayoría de un margen de 44 a 1 . En total, los 12 distritos occidentales habían dado en las elecciones de concejales en 1945, 13.449 [sic] votos a los liberales comparados con 11.377 [sic] para los conservadores. Por el tiempo de las elecciones de 1958 para Cámara, los 
últimos obtuvieron 35.105 [sic], mientras los primeros sólo [sic] consiguieron 17.992 [sic]. Cerca del fin del Frente Nacional [1974], poco había cambiado. En las elecciones de 1970 para la Cámara, los conservadores (incluía el ala conservadora de la ANAPO) recibieron 31.329 [sic] votos en el occidente; los liberales solamente 11.656 [sic]. La fuerte correlación entre el occidente que fue duramente castigado por la violencia y este dramático movimiento electoral sólo [sic] puede ser explicado claramente por la intimidación política y por la relocalización física de muchos campesinos y aldeanos liberales, hacia el sureste, en áreas liberales más seguras ${ }^{37}$.

Una apreciación muy similar aporta Alfredo Cardona. De acuerdo con su análisis, la violencia tuvo características distintas y actores diferentes en cada uno de los municipios del occidente caldense; en estrecha relación con el hecho de que los pueblos contaran con mayorías liberales (por ejemplo, en Supía, Marmato, Quinchía, Santuario y Balboa) o conservadoras, tal como ocurría en el resto del departamento. Para Cardona, la violencia oscilaba entre el amedrentamiento y la retaliación. Así,

Balboa se viorodeada de enemigos, al igual que Santuario, Quinchía y Marmato; bandas criminales del Águila y Ansermanuevo [Valle del Cauca] asolaron los campos, desplazando a las familias liberales que tuvieron que huir para salvar sus vidas. En represalia y no como autodefensa, se conformaban bandas con rótulo liberal, como la de Mariano Cano, que se dedicó a quemar las casas de los conservadores y a robar las cosechas de café de sus enemigos políticos $^{38}$.

Tras los procesos electorales venía el nombramiento de los funcionarios y empleados para los cargos públicos, de un gabinete departamental o la designación de un alcalde; hechos que se constituían en fuente de discordias políticas, de pronunciamientos y denuncias públicas a través de la prensa, y de la comidilla

37 Christie, Oligarcas, campesinos..., 154.

38 Alfredo Cardona, «Una joven valerosa», El Diario, 19 de noviembre de 2017, http://www. eldiario.com.co/seccion/LAS+ARTES/una-joven-valerosa1711.html. 
preferida en los diferentes pueblos y ciudades del Eje Cafetero. El triunfo o la derrota electoral repercutían directamente en el nombramiento o en la remoción del personal vinculado al Estado. El peso de los gamonales políticos era de vital importancia para las recomendaciones políticas a cargos o empleos públicos, lo que a su vez generaba nuevas redes de lealtades y compromisos, tanto en términos de proselitismo político, de participación en mítines políticos a favor de un candidato o en contra de un político opositor y, por supuesto, para acometer los actos de violencia política los cuales se requirieran. Como señala Christie, también se acostumbraba a que los empleados públicos nombrados «... entregaran una parte de su sueldo a la Dirección de su partido» ${ }^{39}$.

Por otra parte, el ambiente político también se tensionaba por la constante intervención de la Iglesia en los temas públicos de la política nacional y local. Como lo muestran Christie y Ortiz, al grito de ¡viva Cristo Rey!, los curitas de los pueblos arengaban a sus fieles y señalaban de manera bastante virulenta a los liberales de muchos pueblos, lo mismo que a las personas que profesaban otro tipo de religiones ${ }^{40}$. El sectarismo no solo fue estimulado por los partidos políticos. Al igual que en muchas regiones de Colombia, la Iglesia católica retroalimentó los odios sectarios de la población caldense, tanto contra los liberales, como contra los comunistas. En no pocas ocasiones se llegó a señalar que el Partido Liberal era un instrumento de la "maléfica» subversión comunista. Por su parte, la prensa de esta corriente no cesaba de denunciar la intromisión de los curas en asuntos de política partidista y el azuzamiento en general de los feligreses.

Ortiz halló lo siguiente:

... varios curas del Quindío se inmiscuyeron en las acciones de las cuadrillas y de los pájaros y alimentaron contactos con los cabecillas [...] de un cura se ha oído decir que, vestido de civil y con pistola al cinto, acompañaba a las bandas de violentos conservadores. 
Este autor agrega que los clérigos no participantes activamente en la persecución de liberales cohonestaron con el silencio las andanadas de los caciques políticos conservadores. También menciona que, en otras ocasiones, algunos curas se negaban a dar la sepultura católica a ciertas personas, otros rehusaban oficiar misas «a la intención de determinados difuntos»e, incluso, exigían a algunos liberales desalojar los templos en las misas dominicales ${ }^{41}$.

FigurA NRo. 3. Áreas de violencia en Caldas 1948-1953.

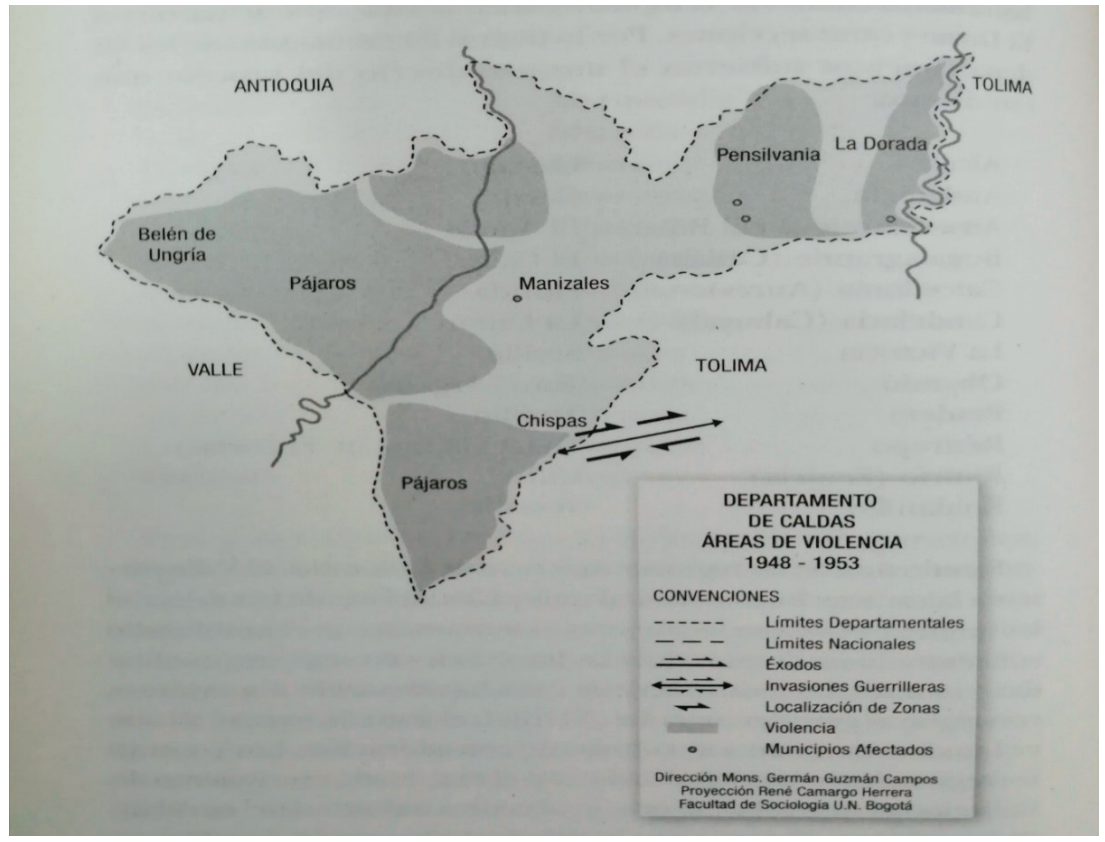

Fuente: Germán Guzmán Campos, Orlando Fals Borda y Eduardo Umaña Luna, La Violencia en Colombia, t. 1 (Bogotá: Prisa Ediciones, 2012), 150.

41 Ortiz, Estado y subversión ..., 201-202. 
Es necesario indicar que, bajo el ropaje de las consignas sectarias, se cometieron un sinnúmero de arbitrariedades y atrocidades, las cuales han llevado a muchos investigadores a hacer referencia a cierta banalidad dentro de la violencia política ${ }^{42}$. De igual modo, esta tiene un trasfondo estrechamente relacionado con la economía o con negocios como el despojo de tierras, el robo de café o ganado; o la compra de estos a precios irrisorios que no necesariamente se explican en términos de lucha de clases.

En su libro sobre la violencia en el Quindío, Carlos Miguel Ortiz aporta un esclarecedor capítulo sobre «lo económico en La Violencia». Destaca que, en medio de las beligerancias políticas, los asesinatos y las amenazas, los habitantes de zonas rurales y cascos urbanos debían continuar dedicados a las labores económicas las cuales les reportaban su sustento. Es claro que, en medio de una sociedad sometida al patronaje de redes políticas clientelistas, así como a la explotación de la mano de obra con salarios muy desiguales, la apropiación del trabajo social producido también quedaba inmerso en medio de las relaciones conflictivas de la época y el lugar. Agrega que incluso los grupos armados participaban en el reparto de lo producido, mediante coacción o violencia directa $^{43}$. Apoyado en documentos judiciales y testimonios de la época, el autor describe los diversos mecanismos a los cuales apelaron tanto liberales como conservadores para usufructuar la violencia en la zona del Quindío. Así,

Las oportunidades se posibilitaron a conservadores como liberales, pues los procesos de homogenización operaban de ambos lados, según las veredas: las ventas de liberales, que ya se habían empezado a dar desde los primeros años de La Violencia, serían ahora más frecuentes; las ventas de conservadores fueron

42 «La banalidad de la violencia apunta hacia varios aspectos nuevos que son propios de los fenómenos presentes: sus dimensiones tan heterogéneas que no permiten que surja un único eje de conflicto, su ausencia de articulación con las identidades colectivas previas, las redes de dominación que tejen, las oportunidades que ofrecen, su compatibilidad con el mantenimiento, al menos formal, del Estado de derecho». Daniel Pécaut, «De la violencia banalizada al terror: el caso colombiano», Controversia, n. ${ }^{\circ} 171$ (1997): 10, 16.

43 Ortiz, Estado y subversión..., 291. 
especialmente numerosas en la zona de la cordillera desde 1954 y en la zona del río La Vieja conocieron su mayor intensidad desde 1958-1959, bajo la amenaza de las cuadrillas alineadas con el M.R.L. [...]

En el comercio rural, el robo de ganado se generalizó constituyéndose en la acción más distintiva de las cuadrillas liberales o de sus aprovechadores, así como el rubro del café había caracterizado sobre todo a los conservadores; la razón es que las zonas ocupadas por la guerrilla liberal de la cordillera se situaban, o en el límite del área del café, o en el área exclusivamente ganadera. Las cuadrillas liberales del Río [sic] La Vieja fueron también, ante todo, como las conservadoras, negociadores de café saqueado ${ }^{44}$.

Los autores del libro sobre La Violencia en Marquetalia llegaron a conclusiones muy parecidas. Al respecto, aportaron una tabla muy detallada con cerca de cincuenta casos de traspasos de tierras en el periodo de 1946 a 1965 en dicho municipio del denominado «Alto», oriente caldense. Y señalan que a través del boleteo se presionaba a los liberales de la zona para vender sus lotes, sus casas, sus solares, sus tiendas, sus mejoras, entre otros bienes, por un precio menor del real. «Los campesinos liberales que emigraron de la región, tuvieron que vender sus propiedades a precios muy bajos - en algunos casos antes de salir de la región, y en otros, años más tarde-» ${ }^{45}$.

Con estas breves notas esperamos haber brindado un panorama de la violencia en la región del Viejo Caldas. Queda claro que los sectores más temerarios de los partidos políticos desataron toda la espiral de violencia la cual hemos venido reseñando someramente. Se operaba bajo una lógica binaria de desconfianza, de recelos y de múltiples recriminaciones. Como señalan Guzmán, Fals y Umaña, «El raciocinio es monstruoso, pero de macabra elementalidad: los conservadores sostienen

44 Ortiz, Estado y subversión...,292. Ortiz es tajante cuando señala: «Confiésenlo o no, todos los comerciantes estaban por lo menos virtualmente relacionados con las compras de La Violencia», 315.

45 Ramírez y Jiménez, Marquetalia..., 109. 
al gobierno que hace la violencia, luego deben ser aniquilados; los liberales hacen la revolución contra el gobierno conservador, luego deben ser aniquilados» ${ }^{46}$.

Ni siquiera en la búsqueda de la paz —o en el «olvido del odio»- se lograban poner de acuerdo los seguidores de uno u otro partido - los cuales actuaban como fanáticos correligionarios-. De inmediato afloraban los prejuicios políticos que hacían añicos los intentos de paz de estos años. Desdelas páginas de los periódicos liberales más moderados invitaban a dar completamente la espalda al pasado y a despojarse de todo sentimiento vengativo. Lo interesante es que el llamado no era solo a los conservadores, sino especialmente a los liberales para que no siguieran «rumiando» venganzas y para que con «caridad cristiana» aplicaran el bálsamo del perdón sobre las grandes heridas nacionales. De esa manera, se podría estar a tono con la invitación de Rojas Pinilla para que el país entrara en un periodo de enfriamiento de las pasiones políticas $^{47}$.

Desde el lado conservador se contestaban estos llamados a la paz y a la reconciliación política en tonos bastantes irónicos y recalcitrantes. En una columna publicada en La Patria, en el año 1955, denominada «La rúbrica de jota» se afirmaba lo siguiente:

... tras la bandera de la "paz" liberal caminan muchas cosas. A renglón seguido se decía que con esa bandera de la paz "se ha encubierto el bandolerismo, la revuelta, la subversión, el cálculo político, la maniobra subterránea, el galope nocturno contra las instituciones.

El columnista denunciaba la cantidad de discursos, editoriales y manifiestos sobre la paz, los cuales no eran más que una «fraseología almibarada y falaz». Igualmente, recurrían al argumento de la cercanía de los liberales con las tácticas del comunismo internacional que ponían en riesgo la maltrecha 46 Guzmán Campos, Fals Borda y Umaña Luna, La Violencia ..., 116. 47 El Diario [Pereira], «Odio al odio», 7 de julio de 1953: 4. 
democracia colombiana. Por eso, concluía el autor de la columna que frente a la «paz liberal»: ¡Huy, qué miedo! ${ }^{48}$

La Iglesia, por su parte, no cesaba de hacer referencia a la falta de educación cristiana integral de los colombianos, la cual había llevado la pérdida de valores y «...al desconocimiento de los fundamentos de la autoridad, sus prerrogativas y graves obligaciones» ${ }^{49}$. De ahí las enormes carencias en el proceso civilizador de la nación colombiana. «Ello ha facilitado la anarquía y los brotes de pasiones impidiendo el cultivo de las virtudes indispensables para el orden social ${ }^{50}$.

Los debates y las posturas públicas de los sectores más conservadores se permearon igualmente - en el contexto de la Guerra Fría - de las disputas metafísicas entre el materialismo y el espíritu para poner de presente las amenazas del comunismo sobre la civilización occidental ${ }^{51}$, lo mismo para justificar la pacificación vía intervención cívico-militar y las continuas declaratorias de estado de sitio $^{52}$. La política, tanto a nivel nacional como regional, oscilaba entre los reproches, la desazón y la esperanza de un futuro renovado. Destacados personajes de la vida pública como el general Julio Londoño hacían referencia a una «nación en crisis», de una nacionalidad caracterizada por una profunda

... discordancia de los diversos elementos que no permite[n] una unidad fuerte y vigorosa $[. .$.$] que trae la disgregación que$ se ofrece desoladoramente en la antagónica separación que hay entre la actividad de los diversos ministerios, entre el ejército y la policía, entre capital y provincia, entre ciudad y campo, patrono y obrero, oligarca y proletario, deber y derecho ${ }^{53}$.

48 La Patria [Manizales], «La paz ¡Huy qué miedo!», 14 de mayo de 1955: 4.

49 Boletín Arquidiocesano [Manizales]. Tomo XXI, n. ${ }^{\circ}$ 240, noviembre de 1958: 392.

50 Boletín Arquidiocesano [Manizales]. Tomo XXI, n. ${ }^{\circ}$ 240, noviembre de 1958: 392.

51 Roberto Urdaneta Arbeláez, El materialismo contra la dignidad del hombre. Su impacto en la vida colombiana (Bogotá: Editorial Lucros, 1960), 43.

52 Conforme al prototipo francés en que se inspira, el estado de sitio no es ni «estado de paz» ni «estado de guerra». El presidente y toda la rama ejecutiva adquieren poderes extraordinarios y excepcionales para definir discrecionalmente qué conductas políticas constituyen atentados al orden. Marco Palacios, Entre la legitimidad y la violencia: Colombia 1975-1994 (Bogotá: Editorial Norma, 1995), 206.

53 Julio Londoño, Nación en crisis (Bogotá: Ministerio de Educación Nacional, 1955), 13-14. 
De este modo, la paz y la democracia continuarían en vilo frente a una violencia que lamentablemente no dejaba de reproducirse y retroalimentarse de las pasiones sectarias y del recrudecimiento de una guerra sucia, aquella donde las fuerzas armadas colombianas desempeñaron un papel protagónico.

El estudio de Ortiz muestra que el accionar del Ejército fue más efectivo desde el inicio de los Gobiernos del Frente Nacional al lograr afectar la estructura organizacional de algunas cuadrillas y al dar de baja a varios de sus cabecillas ${ }^{54}$. No se puede pasar por alto que, desde los inicios del Frente Nacional, se decretó una nueva amnistía la cual pudo haber contribuido a motivar la desmovilización armada de muchos de los integrantes de estas cuadrillas. Así,

Las personas que hubieren cometido en los Departamentos [sic] antes aludidos [Caldas, Cauca, Huila, Tolima y Valle del Cauca] los delitos a que se refiere el artículo $2^{\circ}$ de este Decreto, con anterioridad al 15 de octubre de 1958, podrán solicitar al Gobierno que se suspenda el ejercicio de la acción penal contra ellas, si se obligan a reincorporarse a la vida civil ordinaria, a someterse a la Constitución y a las leyes de la Republica observando buena conducta bajo la vigilancia de las autoridades, y absteniéndose de todo acto que pueda perturbar el orden público o la tranquilidad social ${ }^{55}$.

Sin embargo, en 1962 se registraban 161 cuadrillas en los cinco departamentos antes mencionados, estas agrupaban cerca de 2760 hombres $^{56}$. ¿Había fracasado el pacto político entre liberales y conservadores en las bases populares? Ortiz señala, de manera detallada para el caso del Quindío, la forma como muchas de aquellas cuadrillas, en lugar de desaparecer, terminaron unas aliándose con el Ejército; pero otras asumieron las banderas del

54 Ortiz, Estado y subversión..., 247.

55 Presidencia de la República, «Decreto 328 de 1958 (noviembre 28). Por el cual se dictan disposiciones tendientes a facilitar el afianzamiento de la paz en los departamentos en donde subsiste el estado de sitio» (Bogotá: Imprenta Nacional, 1958).

56 Ortiz, Estado y subversión..., 247. 
Movimiento Revolucionario Liberal (MRL), otras siguieron las reivindicaciones de las nuevas organizaciones guerrilleras de corte marxista y otras más se dedicaron al pillaje. De igual modo, hay que destacar que el Frente Nacional había logrado «paliar» las aspiraciones políticas, las cuales habían llevado a la movilización armada de algunos sectores del liberalismo al obtener un cincuenta por ciento de los cargos del Estado ${ }^{57}$.

El problema fue cómo nombrar estas nuevas formas de violencia que seguían afectando la región y al país en general. Marco Palacios plantea una reflexión muy pertinente sobre esta situación particular:

Si en plena Guerra Fría se acordó llamar "la Violencia" a la confrontación armada de 1945-1954, nunca se supo cómo nombrar la guerra de guerrillas revolucionarias de los años $60 \mathrm{y}$ $70 \ldots$ sin saber a ciencia cierta si se trataba de una continuidad o de una ruptura en los modos, móviles y accionar de los grupos violentos, lo cierto es que se sigue retroalimentando una profunda desazón frente a un conflicto "que por su misma duración se nos presenta como si fuera un fenómeno natural, consustancial a la historia, la geografía y la psiquis nacionales" ${ }^{\prime 2}$.

Con base en estos primeros análisis se podría decir que hubo un proceso de pacificación sin paz, el cual dejó bastante comprometida la imagen de los efectivos de las Fuerzas Armadas, quienes a pesar de buscar legitimar, por diversos medios, su accionar cívico-militar, se constituyeron en un nuevo elemento del conflicto armado en distintas regiones del país al involucrar a la población civil mediante la promoción de las autodefensas campesinas con base en cuatro principios: vigilancia total y continua; sistemas de alarma oportuna; reacción natural e inmediata y apoyo mutuo entre personal civil y también con miembros del Ejército, para contrarrestar la acción de guerrillas

57 Ortiz, Estado y subversión..., 247.

58 Marco Palacios, Violencia pública en Colombia, 1958-2010 (Bogotá: Fondo de Cultura Económica, 2012), 49. 
y toda clase de facinerosos ${ }^{59}$; y también bajo la llamada guerra psicológica que, en los años setenta, se extendió del campo hacia la ciudad (en barrios populares, sindicatos y universidades), aspectos que, lamentablemente, se ha prolongado bajo nuevas modalidades hasta nuestros días, dejando un lastre de abusos de autoridad y continua violación de los derechos humanos.

Como señala el historiador Pierre Gilhodes, «...se puede afirmar que el Ejército combate la violencia sin analizarla mucho, sin interrogarse mucho sobre sus causas, sus implicaciones reales. Actúa como un mecanismo de defensa de la sociedad o también de defensa o reivindicación de sus muertos» ${ }^{60}$.

No cabe duda que en muchos momentos el sonido de las botas militares fue aclamado por muchos sectores de la sociedad y por algunos partidos políticos, como una alternativa necesaria para recuperar o instaurar el orden político y moral de la nación que, al parecer, se había extraviado en medio de la exacerbación de los sectarismos políticos de aquellos años.

Es claro, tal como lo muestra Carlos Miguel Ortiz, que el desempeño del Ejército se debe analizar en dos periodos distintos. Un primer momento de 1954 a 1958 de «relativa impotencia» para enfrentar los grupos armados y disminuir las cifras de homicidios, robos, riñas, amenazas, entre otros. Y un segundo momento, a partir de 1962, en el cual la balanza se inclina a favor del despliegue de la acción cívico-militar del Ejército en las distintas subregiones del departamento ${ }^{61}$. Igualmente, es necesario analizar esta institución más allá de un simple aparato de represión, como el mismo Ortiz recomienda. Cuando se empieza a estudiar con más detalle todo este caudal de información recopilada se evidencia

59 Teniente coronel Cayo Eduardo Jiménez Mendoza, «Autodefensa», Revista de las Fuerzas Armadas XII, n. ${ }^{\circ} 35$ (1965): 178-180.

60 Pierre Gilhodes, «El Ejército colombiano analiza la Violencia». En Pasado y presente de la Violencia en Colombia, compilado por Gonzalo Sánchez y Ricardo Peñaranda (Bogotá: CERECIEPRI, 1995), 351.

61 Ortiz, Estado y subversión ..., 265. 
una cierta paradoja. Ya que, se asume el papel del Ejército durante aquellos años como un garante de gobernabilidad $-\mathrm{y}$ de aparente imparcialidad política-, pero a todas luces, era evidente su precariedad en lo que respecta a su capacidad logística y sus modalidades de persuasión sobre la población civil.

En lugar de una proyección democrática de la seguridad nacional, al cabo de los años se acentuó su marcada dimensión militar en el contexto de la Doctrina de Seguridad Nacional, en la definición de un enemigo interno que, en este caso, podían ser las viejas guerrillas liberales, la persistencia de los grupos de bandoleros o los primeros brotes de guerrillas comunistas. Como se dijo anteriormente, La Violencia había dejado de ser entre liberales y conservadores para convertirse en la identificación de agitadores comunistas. En este sentido, resulta sugerente la tesis de Francisco Leal cuando señala:

...mediante la afirmación del anticomunismo, [...] el concepto de seguridad nacional desplazó en importancia al tradicional de defensa nacional. La defensa nacional se convirtió entonces en el medio para garantizar la seguridad, y de esta forma quedó involucrada también en la lucha anticomunista ${ }^{62}$.

El balance genera una sensación de perplejidad y desasosiego, dado que, a pesar de los augurios de superar el pasado y germinar el presente, la violencia, la intolerancia y la inestabilidad política no cedían. Los diversos acuerdos políticos no eran suficientes para restablecer la normalidad. Ni Rojas, ni la Junta Militar, ni el Frente Nacional habían logrado cerrar las heridas. En medio de los lenguajes heroicos, nacionalistas y carismáticos no hubo una transición significativa ni rupturas definitivas, pese a lo dinámico que es el periodo en sus relaciones internas y en sus

62 Francisco Leal Buitrago, «Una visión de la seguridad en Colombia», Análisis Politico 24, n. 73 (2011): 3 
diversas formas de referencia o relacionamiento con otra serie de acontecimientos a una escala más global ${ }^{63}$.

FigURA NRO. 4. Organización de la autodefensa.

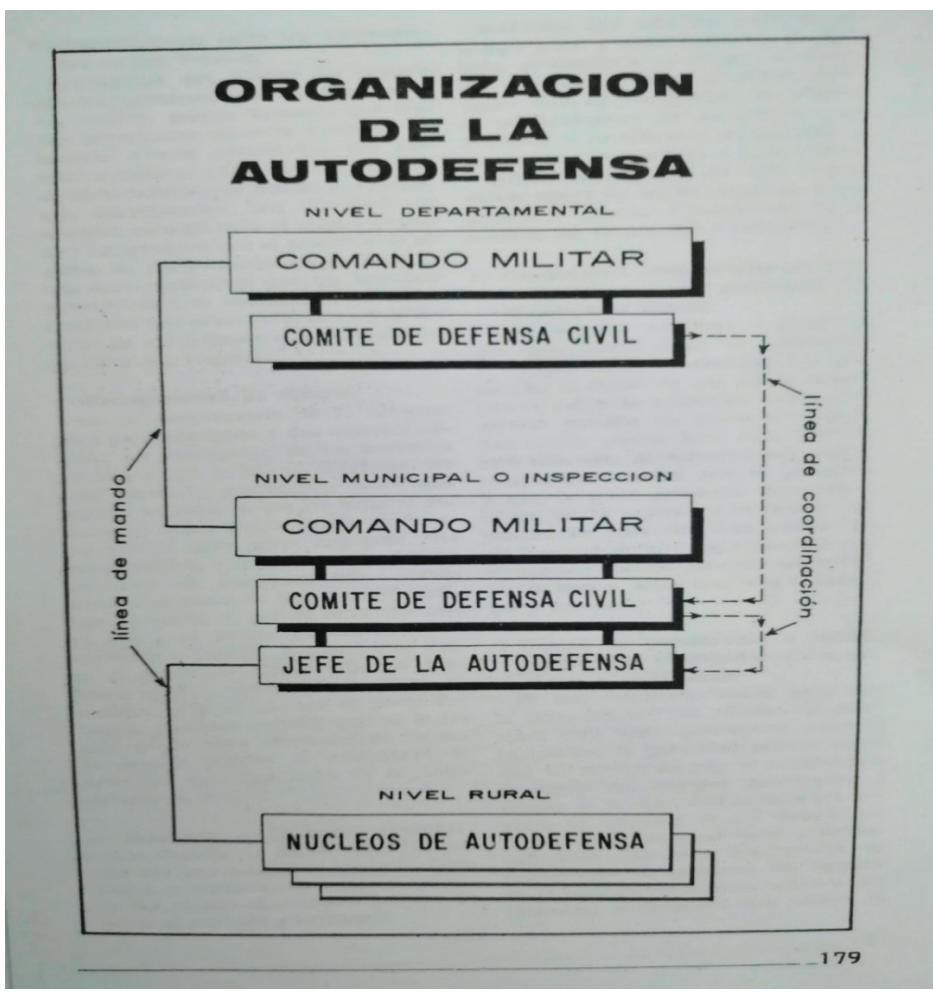

Fuente: teniente coronel Cayo Eduardo Jiménez Mendoza, «Autodefensa», Revista de las Fuerzas Armadas XII, n. 35 (1965), 179.

$63 \mathrm{Al}$ respecto, «Esa larga transición de la democracia a la dictadura y luego a lo que se ha dado en llamar [...] ["]democracia restringida [...] ["], fue en verdad un proceso paulatino. Puede decirse incluso, que la quiebra de la democracia ya existía cuando Rojas se tomó el poder y que esta pausa dio a los partidos la oportunidad de reflexionar y llegar a un acuerdo para restablecer la legalidad constitucional. Pero fue la manera como se planteó este restablecimiento formal de las instituciones democráticas la que truncó el desarrollo político, toda vez que su fórmula de repartición burocrática del poder dio carta de ciudadanía al continuismo político y su carácter claramente excluyente, fijó las bases para la inestabilidad permanente que sigue padeciendo el sistema político colombiano». David Roll, Inestabilidad y continuismo en la dinámica del cambio político en Colombia (Bogotá: ICFES, 1999), 200. 
Sobre el estudio de las Fuerzas Armadas

Los estudios sobre las Fuerzas Armadas en Colombia tienen sus inicios en la década de los años sesenta, de acuerdo con la relevancia que habían ganado estas con relación a la cuestión nacional referida a La Violencia y al papel jugado por los militares al estar en el poder. Esta revisión bibliográfica aborda dos grupos: aquellos enfocados en el ámbito nacional y los referidos a la región caldense en particular.

En el primer grupo se encuentra el balance realizado por Adolfo León Atehortúa: Los estudios acerca de las fuerzas armadas en Colombia: balances y desafíos ${ }^{64}$, en el cual el autor identifica cuatro bloques temáticos en los análisis existentes sobre el tema: 1) los estudios tradicionales herencia del positivismo, 2) los estudios tradicionales y propuestas para el debate, 3) los estudios extranjeros contribuciones para la academia, y 4) los estudios desde la academia.

Alrededor del primer bloque, Atehortúa reúne la literatura producida especialmente por militares, quienes sitúan a la institución en tres momentos históricos: en su papel en la lucha independentista y otros acontecimientos del siglo XIX, en su fundación moderna referida especialmente a la creación de la Escuela Militar durante el mandato de Rafael Reyes Reyes, y en su bautizo en el fuego que tiene que ver con los conflictos con el Perú y la presencia del Ejército colombiano en la guerra de Corea. En esta primera clasificación, además de las memorias y relatos anecdóticos de los militares, hizo su participación la Academia Colombiana de Historia, con el libro ganador del concurso para "promover los pensamientos patrios» de Henao y Arrubla ${ }^{65}$, quienes configuraron una narrativa heroica de esta institución colombiana, al recrear una línea continua entre el ejército de Bolívar y el actual.

64 Adolfo León Atehortúa, «Los estudios acerca de las fuerzas armadas en Colombia: Balances y Desafíos» Análisis Político, n. ${ }^{\circ} 51$ (2004): 12-24.

65 Jesús María Henao y Gerardo Arrubla, Historia de Colombia (Bogotá: Librería Colombiana, 1936). 
En segundo lugar, se hallan otros estudios que el autor demarca como tradicionales, pero tienen un mayor componente investigativo y reflexiones más elaboradas por parte de militares retirados. Estas giran alrededor del «...papel de las instituciones frente al peligro comunista, la subversión, la delincuencia común y los múltiples enemigos del ciudadano y el Estado» ${ }^{66}$. Aquí la producción bibliográfica de personajes como Fernando Landazábal $^{67}$, Alberto Ruiz Novoa ${ }^{68}$ y Álvaro Valencia Tovar ${ }^{69}$ tuvieron un peso significativo para el entendimiento desde adentro y la discusión alrededor de las doctrinas de seguridad y las escuelas militares del periodo, las cuales tuvieron como marco internacional la Guerra Fría y las dictaduras en el Cono Sur.

En los estudios de los estudios extranjeros que tienen como objeto de estudio los militares en el poder en Latinoamérica, sobresale el trabajo pionero de Alain Rouquié, El Estado militar en América Latina, en el cual explica que, para el caso de Colombia, existió un predominio civil que mantuvo subordinadas las fuerzas militares a lo largo del siglo pasado. Este autor francés señala como características del cuerpo castrense colombiano, a diferencia del resto de Latinoamérica, su tardía profesionalización hacia mediados del siglo xx y su dedicación al control de orden público interno, en especial su lucha contra las guerrillas comunistas ${ }^{70}$. Al mismo tiempo, entre las obras de extranjeros sobre las Fuerzas Armadas en Colombia, se encuentra un número importante de contribuciones, especialmente de tesis doctorales y del nivel de maestrías producidas en Estados Unidos, las cuales tuvieron dentro de sus objetivos decantar el papel de las fuerzas militares en la sociedad. Entre los trabajos más destacados tenemos el de

66 Atehortúa, «Los estudios...», 14.

67 Fernando Landazábal, La subversión y el conflicto social (Bogotá: Tercer Mundo Editores, 1980).

68 Entre otros de Alberto Ruiz Novoa se destacan los siguientes: El gran desafio (Bogotá: Tercer Mundo Editores, 1965); El batallón Colombia en Corea 1951-1954 (Bogotá: Empresa Nacional de Comunicaciones, 1956). Y Enseñanzas de la campaña de Corea aplicables al Ejército de Colombia (Bogotá: Editorial Antares, 1956).

69 Álvaro Valencia Tovar, El final de Camilo (Bogotá: Tercer Mundo Editores, 1976); Testimonio de una época (Bogotá, Planeta, 1992).

70 Alain Rouquié, El Estado militar en América Latina (México: Siglo xxı Editores, 1984), 230-232. 
Anthony Maingot ${ }^{71}$, Richard Maullin ${ }^{72}$ y Willy Mury ${ }^{73}$, quienes contaron con estadísticas y otro tipo de documentos de suma relevancia, que aún hoy son de difícil acceso para los investigadores en Colombia.

El aporte de este grupo reside en la seriedad de su distante mirada. Sus escritos no sólo [sic] son los primeros en acercarse al tema con metodologías científicas y cierto rigor académico, también los caracteriza la búsqueda de una mayor profundidad en el análisis y la disposición hacia resultados mejor elaborados y objetivos ${ }^{74}$.

En el último bloque de la clasificación elaborada por Atehortúa se encuentra la producción realizada en el ámbito académico universitario, la cual es amplia y sus intereses de estudio han sido disimiles. Un estudio pionero es el de Francisco Leal Buitrago llamado Política e intervención militar en Colombia ${ }^{75}$, el cual aporta una interesante visión acerca del proceso donde los militares dimitieron de la mediación bipartidista y generaron las condiciones para una inserción autónoma en el sistema político bajo el Frente Nacional ${ }^{76}$.

Seguido a este texto se encuentra la obra La República de las armas. Relaciones entre Fuerzas Armadas y Estado en Colombia: 1960-198077. Uno de los puntos centrales de esta investigación, referido al binomio Fuerzas Militares y Estado, tiene que ver con la superación de la subordinación del estamento militar, no tanto por la frecuencia de su aparición en la escena política sino

71 Anthony Maingot, «Colombia: Civil-Military Relations in a Political Culture of Conflict» (Dissertation Ph.D., University of Florida, 1967).

72 Richard Maullin, Soldiers, guerrillas and politics in Colombia (Lexington: Lexington Books, 1973).

73 Willy Mury, «L'armée colombienne. Etude d'une institution militaire dans ses rapports avec la société en transition, 1930-1974» (Tesis doctoral, Universidad de París, 1975).

74 Atehortúa, «Los estudios...», 16.

75 Franciso Leal Buitrago, «Política e intervención militar en Colombia», Revista Mexicana de Sociología 32, n. 3 (1970): 491-538

76 Medófilo Medina, «Historiografía colombiana y latinoamericana Vol. II». En La historia al final del milenio. Ensayos de historiografía colombiana y latinoamericana, comp. por Bernardo Tovar Zambrano (Bogotá: Editorial Universidad Nacional de Colombia, 1994), 450.

77 Gustavo Gallón Giraldo, La república de las armas. Relaciones entre Fuerzas Armadas y Estado en Colombia, 1960-1980 (Bogotá: Centro de Investigación y Educación Popular, 1983). 
por su organicidad institucional; pues una vez que militares en activo ocuparon cargos ejecutivos y administrativos del Estado, entendieron que les era posible reclamar un asiento propio en la mesa de las decisiones políticas. Así lo deja saber el autor:

De una posición de innegable pero desarticulada influencia sobre el aparato de Estado, antes de la iniciación del gobierno del teniente-general Gustavo Rojas Pinilla en 1953, la milicia en su conjunto había pasado a generar un poder propio dentro de dicho aparato... la posición de influencia detentada durante la primera mitad del siglo se encontraba mediatizada por la dependencia que cada una de las Fuerzas Armadas tenía con los partidos políticos, el nuevo poder de la institución militar había comenzado a ejercerse sin mediaciones en el decenio del sesenta, como consecuencia de su presencia directa en las instancias decisorias del aparato estatal, en donde por primera vez alternaba con los restantes agentes, incluidos los partidos políticos, en posición de igualdad ${ }^{78}$.

Así, se construye una visión en la que se contempla que una vez intensificada La Violencia - escenario que permitió al estamento militar tomar las riendas del Estado- se establecieron dos cambios. Uno, la militarización de la sociedad y el involucramiento de la población civil en el conflicto, y dos, la injerencia de las Fuerzas Armadas en instancias decisorias del Estado tras el paso del régimen de Rojas Pinilla.

Por otro lado, se han generado debates entre la profesionalización y la politización de las Fuerzas Armadas, los grados de autonomía de los militares y su independencia con respecto a las autoridades civiles. Estos últimos tópicos han sido abordados bajo el contexto histórico del Golpe de Estado de 1953, y bajo distintas aristas como la violencia de los años 1948 a 1960, los partidos, la intervención extranjera por parte de Estados Unidos y las elecciones.

78 Gallón, La república de las armas..., 15. 
Dentro de los esfuerzos recientes de la universidad colombiana, se encuentran estudios referidos a las Fuerzas Armadas en sí mismas, bajo el abordaje de estrategias militares como la Acción Cívico-Militar (ACM). Al respecto Daniel Castro Morales $^{79}$, dedica especial atención a los procesos de modernización y a las estrategias contrainsurgentes como dos elementos que compusieron la ACM entre los años de 1958 y 1971. Plantea allí la importancia del ejército en la consolidación de la modernización, toda vez que para alcanzar sus objetivos era necesario el mantenimiento de cierto orden. Al tiempo, aleja su debate de las discusiones que ponen en primer lugar a las doctrinas de seguridad, en la medida de que este concepto no es funcional para explicar el actuar del ejército, por obedecer a procesos coyunturales. Además, resalta la influencia de Estados Unidos en la promulgación de una política de contención del comunismo en la que pudieran "ganar las mentes y los corazones», especialmente por medio de la presencia de las Fuerzas Militares como un agente estatal, a la vez que realizaran labores de modernización ligadas al avance social y económico.

Otro trabajo de investigación es el de Pablo Andrés Nieto ¿Subordinación o autonomía? El Ejército colombiano, su relación política con el gobierno civil y su configuración en la Violencia, 1953-1965 ${ }^{80}$. Allí el autor describe el proceso de transformación del ejército colombiano entre 1953 y 1965, a partir del ascenso al poder del general Rojas Pinilla, al indicar cómo la relación entre el cuerpo militar y los cargos ejecutivos no fue unívoca en este periodo. Más bien se dio una reciprocidad pues «... la subordinación política y la autonomía militar del cuerpo castrense fue quebrantada en varios momentos por la intromisión de los militares en las decisiones políticas y [a su vez por] la de los gobernantes [...] en el orden [...] militar». De esta manera, se resaltan las medidas de militarización de la sociedad durante el

79 Castro Morales, «Modernización contrainsurgente...».

80 Pablo Andrés Nieto, «¿Subordinación o autonomía? El Ejército colombiano, su relación política con el gobierno civil y su configuración en la Violencia, 1953-1965» (Tesis de Maestría, Universidad Nacional de Colombia, 2010). 
régimen de Rojas Pinilla con la implementación del concepto de defensa civil y la creación de las autodefensas campesinas, lo que condujo a que civiles se involucraran en el conflicto y a la puesta en marcha del Plan Lazo, el cual incluía la ejecución de acciones cívico-militar con la asesoría de los Estados Unidos en la lucha anticomunista.

En el segundo grupo referido a los estudios sobre el ejército en el departamento de Caldas se encuentra el trabajo de Carlos Miguel Ortiz, quien en su texto Estado y subversión en Colombia, La Violencia en el Quindío años $50^{81}$ dedica una parte a la actuación del ejército. Para ello realiza una periodización que divide en dos momentos. El primero de 1954 hasta 1962, en el que el aparato militar es caracterizado por su composición en recursos humanos, dotación y acciones de mejoramiento por medio de la intervención extranjera, las dificultades que tuvo para enfrentar la guerra no convencional y las tensiones alrededor del enemigo y de la población civil. Y el segundo, a partir de 1962 a 1965, donde la balanza se inclina a favor del despliegue de la acción cívicomilitar en las distintas subregiones del departamento, además de la evidente transformación de la Ejército en términos del perfeccionamiento de sus tácticas antiguerrilla, la dotación y la reorganización de las labores e inteligencia ${ }^{82}$.

Adicionalmente, dicho autor recomienda pensar el ejército más allá de un simple aparato de represión. Idea que se encuentra relacionada con otro documento que, aunque no se trata de una indagación sobre las Fuerzas Armadas, valora los aportes de la presencia de este organismo en la región Caldense durante el periodo de estudio. Se trata del texto De la Violencia a la paz. Experiencias de la Octava Brigada en la lucha contra guerrillas ${ }^{83}$, en el cual se relatan los inicios de esta unidad del Ejército y el despliegue de sus operaciones en Caldas a partir del año de 1962.

81 Ortiz, Estado y subversión...

82 Ortiz, Estado y subversión..., 265-287.

83 VIII Brigada, De la violencia a la paz: experiencias de la Octava Brigada en la lucha contra guerrillas (Manizales: Imprenta Departamental de Caldas, 1965). 
Para ello se expone el punto de vista de los militares alrededor de La Violencia y la incidencia en factores sociales, económicos, e incluso, culturales. Asimismo, relatan lo que significó la ejecución de la pacificación, en particular la ACM puesta en marcha con el Plan Lazo.

Para concluir, se debe señalar que las líneas más desarrolladas al interior de los estudios sobre las Fuerzas Armadas han sido las relaciones entre los militares y el poder político. En ellas se insertan trabajos con un interés marcado por lo que fueron los años de la Dictadura de Gustavo Rojas Pinilla (1953-1957), la Junta Militar Interina (1957-1958) y los años subsiguientes, en los cuales los militares tuvieron un papel importante en la ejecución de las estrategias de contención del comunismo, sobre todo bajo la figura de Alberto Ruiz Novoa.

Sobre las perspectivas poco exploradas en la historiografía de las Fuerzas Armadas se ubican dos elementos. El primero, acerca de los pocos estudios que tienen como objeto el funcionamiento interno del aparato militar, la vida en el cuartel, las relaciones entre los oficiales y soldados, entre otros elementos que constituyen el ethos de lo militar (códigos de honor, obediencia, lealtad, la identidad, el sentido de la colectividad, capacidad operativa, caracterizaciones de la procedencia del personal, entre otros). Y el segundo, sobre la relación de los militares y el poder político en la escala local y regional, lo cual configura el presente esfuerzo investigativo como una oportunidad de indagación para otros interesados en la línea de la historia política y regional.

\section{Sobre el orden de los capítulos}

Este libro, resultado de investigación, se encuentra dividido en cinco capítulos. En el primero se busca revisar la prensa caldense entre 1953 y 1957 —esto es, durante el inicio y el declive de la dictadura del general Gustavo Rojas Pinilla-, con el fin de analizar las distintas etapas de la relación entre los militares y los 
dos partidos políticos tradicionales. Para ello, se seleccionaron los siguientes periódicos: El Diario de Pereira de tendencia liberal; los diarios conservadores La Patria de Manizales y el Diario del Quindio de Armenia; y el semanario Binomio. Fuerzas Armadas y Pueblo, del municipio de Calarcá, adepto al Gobierno militar. Se debe señalar que el cubrimiento periodístico a favor o en contra del Gobierno de Rojas Pinilla varió de acuerdo con el estado de las relaciones de los militares con los partidos y, en especial, de ciertas situaciones como la composición partidista de la Asamblea Nacional Constituyente, la censura de la prensa, la obligatoria transmisión de mensajes oficiales en los medios de comunicación y el recrudecimiento de la violencia en el departamento Caldas. De esta forma, en el acápite se demuestran las líneas de acción de la prensa que, en principio, le dio la bienvenida al régimen militar $\mathrm{y}$, al final del periodo, denunciaron la postura dictatorial de las Fuerzas Armadas en su intento por permanecer en el poder.

En el segundo capítulo se dedica especial atención al análisis de los discursos y la propaganda periodística del coronel Gustavo Sierra Ochoa como gobernador de Caldas entre 1953 y 1956. Tal revisión tiene lugar a partir de sus memorias sobre la gestión al frente del departamento y del semanario El Binomio de Calarcá, en el que, con una muy cuidada edición, se resaltaban las acciones militares tendientes a recuperar la convivencia y la paz en esta región. Al tomar el lema nacional de Rojas Pinilla sobre «Paz, Justicia y Libertad», el régimen militar, a nivel regional, se enfocó en publicar todas las obras de infraestructura y los programas sociales agenciados por el Servicio Nacional de Asistencia Social (SENDAS), con el fin de demostrar que una nueva era para la República se abría con el papel modernizador de las Fuerzas Armadas en el poder, lo cual en su concepto las separaba del sectarismo político característico de la democracia colombiana bajo los gobiernos partidistas. Adicionalmente, fue posible observar la intensificación de las críticas de las altas cúpulas militares acerca de las posturas sectarias y fratricidas de los partidos liberal y conservador, lo que le permitió al Ejército 
vislumbrar una posibilidad de mantenerse en el poder político, lo que a la postre conllevó a crear la imagen del binomio PuebloFuerzas Armadas, también llamada la Tercera Fuerza Política.

Un acercamiento a la acción cívico-militar, la cual tuvo lugar en Caldas entre 1953 y 1964, es el tema que ocupa el tercer capítulo. En este se acude a la prensa caldense, a publicaciones de la Octava Brigada y a la Revista de las Fuerzas Militares con el fin de dar cuenta de la estrategia de pacificación llamada Acción CívicoMilitar, la cual tiene lugar en medio del contexto internacional de la Guerra Fría, lo que sin duda determinó un giro significativo en la doctrina de las Fuerzas Armadas en relación con el tratamiento dado a la violencia y la lucha anticomunista, lo mismo que en torno a la ejecución de obras públicas y programas sociales para el mejoramiento de las condiciones de vida de la población afectada. Además, el propósito principal para el Ejército fue el de «ganar las mentes y los corazones» de la población civil hacia la institución castrense, de modo que se deslegitimara la acción de los bandoleros y se redujeran las cifras de violencia en Caldas. Otro aspecto importante destacado en este es la convergencia de los militares, el clero y la clase política para llevar a cabo este programa, el cual, en 1957, durante la administración del coronel Gerardo Ayerbe Chaux, tomó el nombre de La Batalla por la Paz. Cabe mencionar que este proceso le dio al Ejército la posibilidad de acumular una experiencia militar utilizada luego en contra de los primeros grupos de autodefensa campesina comunista, semillas de los grupos guerrilleros de los años sesenta.

En el capítulo cuarto se analiza a profundidad un sumario consultado en el Archivo Judicial del municipio de Anserma, Caldas, por el delito de "Asociación para delinquir» en contra de trece campesinos de Belalcázar (Caldas) en 1958. En este proceso se rastreó la simultaneidad de las labores agrícolas y armadas de estos personajes de la sociedad rural del Viejo Caldas, los cuales conformaron un grupo embrionario de autodefensa; pero además de esto se delimitaron ciertas relaciones económicas y políticas 
que tensionaron el entramado de violencia bipartidista, todavía en pugna al inicio del Frente Nacional, pero cuyos antecedentes se remontaban a la colonización del valle del río Risaralda a finales del siglo XIX, en donde se enfrentaron terratenientes conservadores y colonos liberales. En este sentido, el análisis propuesto por los autores proporciona un enfoque interpretativo de la documentación, el cual evalúa la experiencia vivida por los protagonistas de los acontecimientos, de forma que, a través de la reconstrucción del contexto de los hechos, se da cuenta del entramado general en el cual estos se articulan, con lo que se puede reconstruir una interpretación más compleja y realista de la racionalidad de estos actores sociales.

Por último, el libro cierra con un capítulo en el que se analizan las acciones administrativas y cívicas del Consejo Administrativo Municipal y la Junta Patriótica Auxiliar en el municipio de Chinchiná (Caldas) durante el Gobierno militar de Gustavo Rojas Pinilla (1953-1957). Esto permite evidenciar los cambios y acuerdos políticos-administrativos realizados por la Dictadura a nivel local para organizar la composición de estos cuerpos colegiados. Así, las acciones de la Junta Patriótica se basaron en la construcción de redes de apoyo al Gobierno militar encabezado por Rojas Pinilla y la adhesión a las políticas departamentales del general Sierra Ochoa. Por su parte, el Concejo Administrativo de Chinchiná se ocupó, entonces, de las acciones legales y de administrar los recursos para la ejecución de políticas sociales bajo el proyecto SENDAS, para orientar así los proyectos y programas de modernización del municipio con el objetivo de construir la paz territorial. 
FIGURA NRO. 5. Infografía: gobernadores militares en Caldas entre 1953-1967.

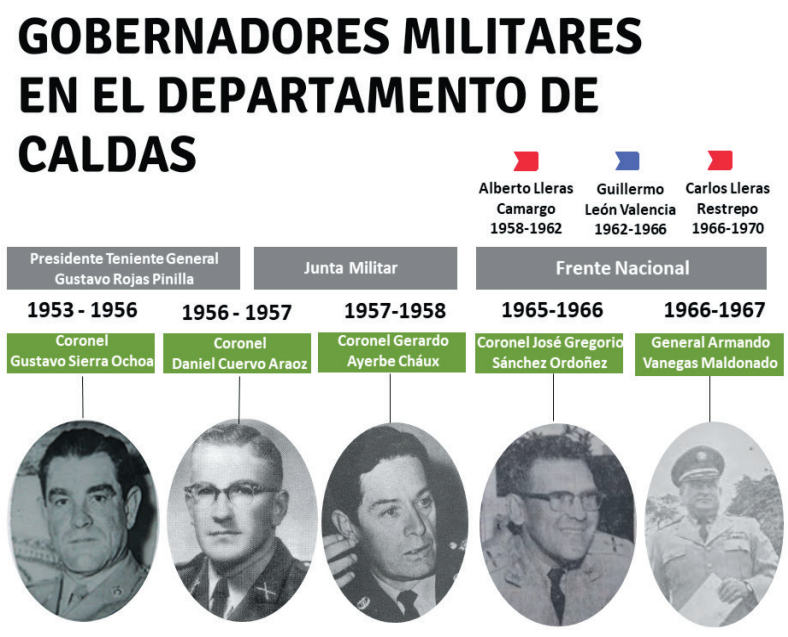

Fuente: elaboración propia.

Figura NRo. 6. Infografía: periodizaciones de La Violencia.

\section{PERIODIZACIONES DE LA VIOLENCIA EN COLOMBIA}

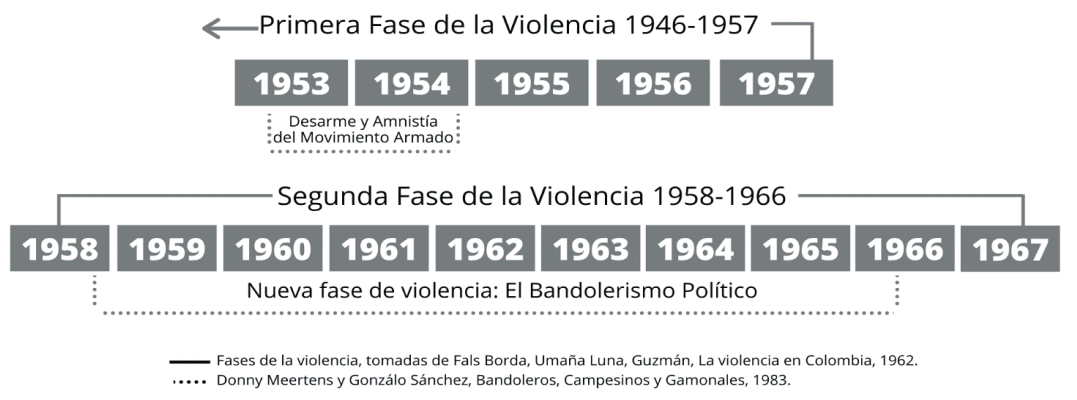

Fuente: elaboración propia. 
Figura NRO. 7. Periodización de la presencia del Ejército.

\section{PERIODIZACIÓN DE LA PRESENCIA DEL EJÉRCITO}

\section{\begin{tabular}{l|l|l|l|l|l}
1953 & 1954 & 1955 & 1956 & 1957 & 1958 \\
\hline
\end{tabular}}

Respuesta del Estado: Conservatización
Pujanza de las Guerrillas vs. Crisis e Impotencia del Ejército

\section{\begin{tabular}{|l|l|l|l|l|l|l|l|l|}
1959 & 1960 & 1961 & 1962 & 1963 & 1964 & 1965 & 1966 & 1967 \\
\hline
\end{tabular}}

Periodo intermedio de lucha Proceso de tecnificación del ejército.Implementación de nuevas militar contra las cuadrillas

Adaptado de Ortiz, Estado y subversión en Colombia. La violencia en el Quindío años 50 (Bogotá: Fondo Editorial Cerec, 1985), 263-287. 


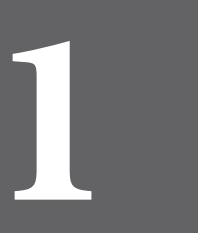

CAPÍTULO

UNO 



\title{
Prensa regional y los gobiernos militares en Caldas (1953-1957): el retorno a la democracia, la censura y la violencia política
}

\author{
Jhon Jaime Correa Ramíre $z^{84^{*}}$ \\ Edwin Mauricio López García ${ }^{85^{* *}}$
}

Este capítulo pretende demostrar, mediante el análisis de la prensa caldense, la relación de varios diarios de la región con el régimen militar del general Gustavo Rojas Pinilla a nivel nacional, y de su representante en el departamento de Caldas, el coronel Gustavo Sierra Ochoa, entre los años 1953 y 1957. Esta relación se vio marcada por los intereses políticos y partidistas de estos periódicos que, en un inicio, mostraron su beneplácito por la llegada de los militares al poder para la pacificación del país, pero

84* Doctor en Ciencias de la Educación de La Red de Universidades de Doctorado en Ciencias de la Educación (RUDECOLOMBIA), Magíster en Ciencia Política de la Universidad de Antioquia e Historiador de la Universidad Nacional de Colombia sede Medellín. Profesor titular de la Universidad Tecnológica de Pereira. Autor de los libros Civismo y educación en Pereira y Manizales (1925-1950) (2015) y Tinta Roja. Prensa política y educación en la República Liberal (1930-1946) (2016).

$85^{* *}$ Licenciado en Etnoeducación y Desarrollo Comunitario y estudiante de la Maestría en Historia de la Universidad Tecnológica de Pereira. Coautor del libro 50/60. Una historia compartida (2016). Ha publicado artículos en revistas especializadas sobre clientelismo durante el Frente Nacional y el proceso de creación del departamento de Risaralda. 
con el desarrollo de la Dictadura y, en especial, el establecimiento de la censura y la intensificación de la violencia en Caldas quitaron su apoyo al régimen y clamaron por el retorno a la democracia y la salida de Rojas Pinilla de la presidencia.

Un resumen del régimen militar en Colombia entre 1953 y 1957 demuestra que este no fue un proyecto político completamente autónomo, sino que por el contrario los militares dependieron del apoyo de los partidos políticos ${ }^{86}$. Su llegada al poder, tras el golpe de Estado en contra de Laureano Gómez, reveló el miedo de ciertas facciones partidistas a que la violencia campesina generalizada en el país le abriera las puertas a una revolución armada ${ }^{87}$. Las Fuerzas Armadas desplegaron en sus primeros años de gobierno una ideología política con elementos de catolicismo y bolivarianismo para llamar a la reconciliación nacional, permitiéndoles ganar cierto grado de autonomía y legitimidad en sectores populares.

Sin embargo, en el momento que los militares intentaron crear una fuerza alternativa distinta al conservatismo y el liberalismo para reelegirse en el periodo de 1958-1962, los partidos se unificaron en torno a un pacto denominado «frente civil» para el retorno de la democracia ${ }^{88}$. De todas formas, la dictadura militar les dejó ciertas enseñanzas a los partidos políticos, las cuales no pasaron desapercibidas. Estas fueron puestas en práctica a partir del Frente Nacional, tales como «la integración bipartidista a nivel burocrático» $\mathrm{y}$ «el control institucional unificado del Estado sobre el conflicto armado» ${ }^{89}$.

En la medida que pasaba la luna de miel de Rojas con los partidos, los gremios, los estudiantes y algunos medios de comunicación, su régimen político empezó a ser señalado como

86 David Bushnell, Colombia, una nación a pesar de sí misma. De los tiempos precolombinos a nuestros días (Bogotá: Editorial Planeta, 1994), 292-293.

87 Guillén Martínez, El poder político ..., 430.

88 Gonzalo Sánchez y Donny Meertens, Bandoleros, gamonales y campesinos (Bogotá: El Áncora Editores, 1985), 41.

89 Leal Buitrago, Estado y politica en Colombia..., 158. 
una dictadura e incluso como «...una revolución de la clase media contra la gente del Country Club» ${ }^{90}$. Esta «revolución militar» se caracterizó por la búsqueda de una base política propia en las capas populares del país. El plan de gobierno para cumplir con este objetivo estuvo marcado por el incremento de los salarios de los trabajadores, las inversiones en salud, la construcción de caminos y carreteras en áreas atrasadas en materia de infraestructura, la titulación de baldíos y la construcción de la paz. Del mismo modo, al inicio de la Dictadura de Rojas Pinilla, fue importante el proceso de pacificación. En junio y julio de 1953 se desmovilizaron grupos guerrilleros en Tolima, Santander, Cundinamarca y Antioquia ${ }^{91}$. En los llanos orientales la mayor desmovilización ocurrió el 12 de septiembre de 1953 con la entrega de armas de Guadalupe Salcedo y 280 de sus hombres al general Alfredo Duarte Blum a cambio de la amnistía para este grupo insurgente ${ }^{92}$.

En este sentido, la Asamblea Nacional Constituyente (de ahora en adelante ANAC), organismo que había sido concebido desde 1951 por Laureano Gómez para llevar a cabo una reforma constitucional de carácter corporativista, y borrar la influencia secular que los liberales, en los años treinta durante la presidencia de Alfonso López Pumarejo, le imprimieron a la Constitución de $1886^{93}$. Este fue luego el punto central en donde se determinaba el apoyo $\mathrm{u}$ oposición de las distintas facciones liberales y conservadoras al régimen castrense de acuerdo con la distribución entre los partidos de los miembros de dicha corporación. Aunque en general el Gobierno militar tuvo mayor cercanía con las fuerzas del partido conservador, en especial con las facciones lideradas por Mariano Ospina Pérez y Gilberto Álzate Avendaño desde

90 Palacios, Entre la legitimidad..., 185.

91 Darío Villamizar, Las guerrillas en Colombia. Una historia desde los orígenes hasta los confines (Bogotá: Debate, 2017), 162.

92 Palacios, Entre la legitimidad..., 186; Orlando Villanueva Martínez, Guadalupe Salcedo y la insurrección llanera, 1949-1957 (Bogotá: Universidad Nacional Colombia, 2012), 491.

93 Diego Nicolás Pardo Motta, Laureano Gómez Castro y su proyecto de reforma constitucional (1951-1953) (Bogotá: Universidad del Rosario, 2008), 64-65; Eduardo Sáenz Rovner, Colombia años 50: industriales, política y diplomacia (Bogotá: Universidad Nacional Colombia, 2002), 127-128; James Henderson, La modernización en Colombia. Los años de Laureano Gómez, 1889-1965 (Medellín: Universidad de Antioquia, 2006), 518. 
1953 hasta 1957, la ANAC fue el termómetro político para revisar el estado de las relaciones con las demás tendencias políticas, pues allí los laureanistas siempre le hicieron oposición; actitud que los liberales asumieron desde finales de $1954^{94}$.

Por esta razón, la composición del personal de gobierno fue un punto nodal de la pugna partidista, ya que se conformó en su mayoría por conservadores, algunos militares y, en menor medida, por liberales; los cuales fueron descalificados por el oficialismo de su partido como «lentejos» por no acatar las órdenes del Directorio Nacional Libera ${ }^{95}$. Este aspecto, de acuerdo con la distribución de puestos oficiales en el Gobierno, fue un elemento de discusión constante en las editoriales periodísticas a nivel regional y llevó a los partidos a disputas para defender su acceso a la administración pública y al manejo de sus respectivas clientelas, lo cual demuestra que a la par de la contienda ideológica discurrió una controversia burocrática en torno a la ANAC.

Los diarios afectos a los partidos Liberal y Conservador siempre demandaron del régimen militar una transición política que permitiera el retorno de la democracia; de allí que en dicho proceso la censura a la prensa fue otro de los puntos sensibles durante la Dictadura. En el cubrimiento noticioso del régimen, los periódicos tuvieron que hallar un balance para emitir sus opiniones políticas de forma que las críticas recayeran en el partido contrario y no en los militares. Es así como la censura fue discutida por la prensa liberal, conservadora y por los medios pro-militares a través de intensos debates, los cuales evaluaban la cuestión entre libertad de prensa y la responsabilidad al emitir juicios sobre el Gobierno. Lo cierto es que las medidas restrictivas sobre los medios de comunicación, a lo largo de este periodo en temas como el orden público y la imposición de notas oficiales, marcaron un punto de inflexión, el cual deterioró la imagen las Fuerzas Armadas hasta el momento de su caída.

94 Palacios, Entre la legitimidad..., 213.

95 Bushnell, Colombia, una nación..., 293. 
A pesar del señalamiento constante de los medios sobre una nueva era política en la que primaban la deposición de los odios banderizos y el sectarismo político, en realidad este periodo estuvo marcado por la intensificación de la segunda fase de La Violencia ${ }^{96}$. Esta nueva ola ocurrida en Caldas y el Valle del Cauca entre 1954 y 1958, estuvo asociada con la cosecha cafetera y el robo de ganado - una de las distintas modalidades estructurales del conflicto armado a mitad del siglo xx descritas por Oquistbajo la complicidad del Gobierno militar, y en la que además, conservadores locales contrataron a pájaros para armar el «negocio de la violencia ${ }^{97}$. Ante la ausencia de elecciones, la violencia no tuvo el matiz político de la primera fase bipartidista en la década de los treinta cuyo fin consistía en conservatizar o liberalizar municipios y/o regiones. Al mediar la década de los cincuenta, bajo un cariz político se desplegó una violencia económica, en la cual, como lo señala Ortiz, mayordomos, fonderos y políticos locales estructuraron el despojo sistemático de fincas, la comercialización de cosechas de café y ganado, y la manipulación bajo amenazas a la mano de obra campesina ${ }^{98}$. La frecuencia y la intensidad de los homicidios, las expulsiones y las masacres aumentaron cada año en las temporadas de la cosecha de cafég9. Precisamente fue en medio de este contexto violento bajo el cual operaron los distintos periódicos regionales, aquellos que editorializaron los hechos cotidianos de exilios, homicidios y robos como un elemento que marcó la disputa editorial a favor o en contra del régimen militar.

\subsection{La prensa regional: actor político y cultural de la sociedad}

Analizar a la prensa como objeto de estudio significa comprender que este medio de comunicación actúa a nivel político y cultural, al cumplir funciones de empresa, de vocero civilizador

96 Palacios, Entre la legitimidad..., 190; Guzmán, Fals y Umaña, La Violencia ..., 52.

97 Paul Oquist, Violencia, conflicto y política en Colombia (Bogotá: Banco Popular, 1978), 309.

98 Ortiz, Estado y subversión..., 291-193.

99 Palacios, Entre la legitimidad..., 234. 
y de tribuna política ${ }^{100}$. Por ello, se resalta que, en lo social, la prensa está interesada en dar a conocer ciertos objetos, autores, temas, percepciones o actitudes, las cuales son publicadas bajo el arbitrio de sus editores ${ }^{101}$. Esta se convierte en un termómetro de la sociedad y en vehículo de expresión y difusión de la ideología que la atraviesa ${ }^{102}$. La prensa como documento histórico puede ser considerada como un dispositivo cultural moderno, el cual representa en cierto grado una democratización de la cultura ${ }^{103}$. En tanto actor político, la prensa

... se convierte en un lugar inestimable para pensar la política y la sociedad $[\ldots]$ inscripta permanentemente en un campo de relaciones que involucra poderes, actores, fuerzas políticas [...] no solo se convierte en un mediador entre la sociedad civil y el estado, sino que reconstruye representaciones del poder y la sociedad en cuyo interior opera [...] la prensa puede cuestionar o consagrar a élites políticas y culturales, poner en tensión o legitimar prácticas políticas y construir su lugar en la esfera pública ${ }^{104}$.

En los archivos de mediados del siglo pasado, y a través de sus páginas, se puede percibir la forma en que los periódicos registraron su adscripción política, la cual se hacía explícita en la mayoría de los casos. Estas publicaciones tenían un trasfondo ideológico con el fin de formar políticamente a sus lectores a través de un conjunto de representaciones simbólicas de la sociedad y la promoción de saberes, valores y normas, las cuales buscaban crear un consenso para ordenar y estructurar el mundo bajo ciertos parámetros $^{105}$. El estudio de la prensa también permite esbozar

100 Álvaro Acevedo y Jhon Jaime Correa. «Empresa, civilización y política: representaciones sobre el oficio periodístico en El Diario de Pereira y Vanguarda Liberal de Bucaramanga durante la República Liberal», Historelo Revista de Historia Regional y Local 5, n. ${ }^{\circ} 9$ (2013): 212.

101 Gustavo Adolfo Bedoya, «La prensa como objeto de investigación para un estudio histórico de la literatura colombiana. Balance historiográfico y establecimiento del corpus», Estudios de Literatura Colombiana, n. ${ }^{\circ} 28$ (2011): 104.

102 Renán Silva, Prensa y revolución a finales del siglo XVIII. Contribución a un análisis de la formación de la ideología de independencia nacional (Medellín: La Carreta, 2004), 16.

103 Bedoya, «La prensa...», 105.

104 Mirta Kircher, «La prensa escrita: actor social y político, espacio de producción cultural y fuente de información histórica», Revista de Historia, n. ${ }^{\circ} 10$ (2005): 116-117.

105 Kircher, «La prensa escrita...», 117-118. 
un perfil identitario de lo político dentro de los periódicos, particularmente en las primeras planas y las editoriales, donde es posible observar las formas textuales en las cuales dicho documento organiza su estrategia y pretende darle visibilidad para que sean fácilmente localizadas y captadas por el lector ${ }^{106}$.

Otro elemento destacable del estudio de la prensa se vincula con la intertextualidad y las múltiples interrelaciones con otras publicaciones partidistas. Estas interacciones dinámicas de los distintos periódicos recrearon los debates y las disputas de los distintos grupos políticos desde sus enfoques ideológicos. Así, estos diálogos periodísticos les permitieron a los editores adelantar intercambios informativos como una forma de convalidarse como tribunas públicas de opinión, no solo en enfrentamiento con las ideologías contrarias de la prensa, sino a su vez, con el afianzamiento y la difusión de los múltiples puntos de vista de un mismo partido sobre ciertas temáticas ${ }^{107}$.

En el caso del estudio de la prensa regional, autores como Acevedo y Villabona explican que estudiar las estructuras y las estrategias de los discursos políticos de la prensa colombiana del siglo XX permite una renovación de la historia política del país, dándole entrada a un enfoque cultural de la política ${ }^{108}$. Por esta razón, al analizar la prensa partidista es de gran importancia evaluar «... las peripecias de la política, las contradicciones, las disidencias y los embates diarios del accionar político» ${ }^{109}$. En cuanto a la región del Viejo Caldas, es pertinente retomar la inquietud de Gil por analizar la forma en la cual «... se construyó la interlocución entre los periódicos de Pereira con los de Manizales, poniendo un énfasis prioritario en la manera como La Patria, el periódico conservador, pudo repeler o contradecir las dinámicas

106 Kircher, «La prensa escrita...», 120

107 Álvaro Acevedo y Jhon Jaime Correa, Tinta Roja. Prensa, politica y educación en la República Liberal (1930-1946). El Diario de Pereira y Vanguardia Liberal de Bucaramanga (Bucaramanga: UIS-UTP-Colciencias, 2016), 328-329.

108 Álvaro Acevedo Tarazona y Juliana Villabona, «Prensa y violencia. El deber y el conservatismo en Santander (1930-1946)», Justicia Juris 12, n. ${ }^{\circ} 1$ (2016), 87.

109 Acevedo y Villabona, «Prensa y violencia...», 98. 
propias de los gobiernos» ${ }^{110}$. En este sentido, uno de los primeros acercamientos a la prensa conservadora regional es el trabajo de López García que analiza en los años cincuenta la ideología católica de aquella y las representaciones creadas alrededor de la violencia y el comunismo como elementos que destruían el orden político de la nación ${ }^{111}$.

\subsection{La llegada de los militares al poder vista desde la prensa regional}

Figura NRo. 8. Publicidad «Caldas saluda».

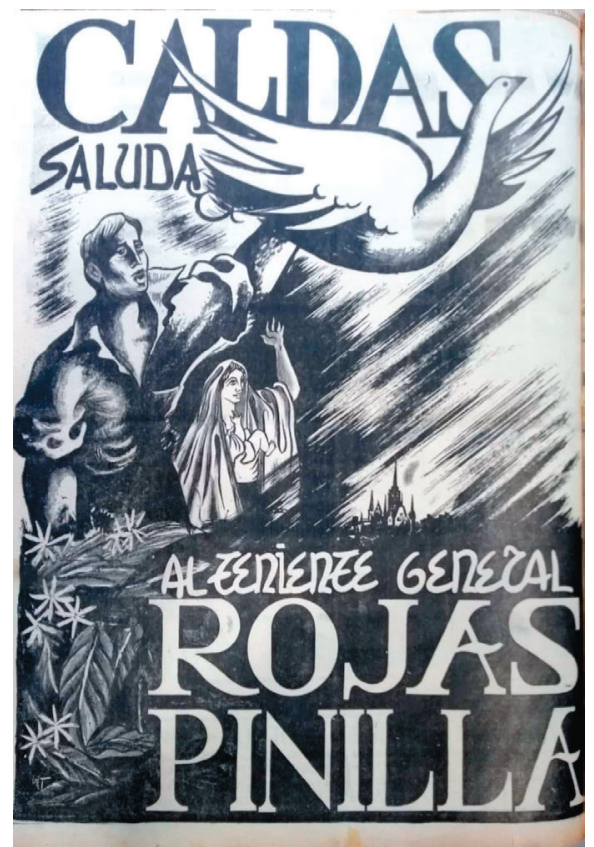

Fuente: La Patria [Manizales], 29 de agosto de 1953.

110 Anderson Paul Gil Pérez. «Miradas historiográficas a la relación prensa e historia en el caso de Pereira», Ciencia Nueva Revista de Historia y Política 2, n. ${ }^{\circ}$ (2018): 148.

111 Edwin Mauricio López García, «El espectro de la violencia y el fantasma del comunismo: Cultura política e ideología conservadora en Caldas. 1953-1956» (Trabajo de grado, Universidad Tecnológica de Pereira, 2019). 
El régimen militar tuvo una legitimidad inicial respaldada por su proyecto de pacificación y reconciliación nacional sustentado en las amnistías a las guerrillas liberales. Además del apoyo irrestricto del ospinismo y el alzatismo en el Partido Conservador, Rojas Pinilla para ganar el favor de los liberales incidió en la composición paritaria de la Corte Suprema de Justicia, tras la renuncia de todos los magistrados de esta en noviembre de $1953^{112}$. De esta forma, el eje discursivo del cubrimiento político de la prensa regional caldense durante 1953 giró en torno a las visiones que tanto el Partido Liberal como el Conservador tenían respecto del Gobierno militar de este mandatario y el golpe de Estado del 13 de junio de dicho año. Ante el nuevo mandato de las fuerzas armadas, El Diario de Pereira, de marcada tendencia liberal; y La Patria de Manizales, periódico conservador, tuvieron disputas en sus páginas. En ellas se observa que la pugna partidista y los recelos políticos se mantuvieron latentes durante el nuevo régimen militar.

Por ejemplo, para El Diario de Pereira con la llegada de Rojas al poder, quedaba atrás el oscuro régimen de Laureano Gómez caracterizado como las sombras, las cuales oscurecieron el ensueño de los antepasados, la anarquía, los atropellos; lo que hacía imposible la concordia, la paz, y la justicia ${ }^{113}$. Los editoriales de este periódico debatían, de manera constante, sobre la pacificación del país cuya solución dependía del desarme de las pasiones políticas y de erradicar el sectarismo, la conjunción del desmonte de las aspiraciones burocráticas de ambos partidos y la inclusión de la oposición en el futuro Gobierno ${ }^{114}$. Estas demandas eran exigidas por el periódico como los propósitos que los partidos Liberal y Conservador debían abanderar.

112 Palacio, Entre la legitimidad..., 212; Mario Alberto Cajas Sarria, «La Corte Suprema de Justicia bajo el gobierno del general Gustavo Rojas Pinilla», Revista de Estudios Sociales, n. ${ }^{\circ}$ 50 (2014), 127-139.

113 El Diario [Pereira], 1 de agosto de 1953: 4.

114 El Diario [Pereira], 23 de julio de 1953: 1. 
La prensa pereirana hacía eco del llamado del general Rojas Pinilla para la reorganización de los partidos. En tal sentido, Emilio Correa Uribe, a la sazón editor de El Diario, pedía que la lucha partidista se desenvolviera por los cauces de una «cultura política democrática y civilizada ${ }^{115}$, al hacer uso del sufragio impío, la proscripción del odio y la incorporación de la oposición en el Gobierno, en lugar de aplastar a los adversarios. Esa cultura política democrática defendida por Correa Uribe implicaba además el receso de los propósitos de partido, al aludir a un concepto difundido por el líder liberal tolimense Darío Echandía, el cual consistía en «...cesar las aspiraciones burocráticas, el afán de dominio de unos sobre otros, la aspiración de los periódicos en convertirse en órganos oficiales, la mentalidad electoral, el caciquismo, [y] todo lo cual conducía al fraude y a la violencia» ${ }^{116}$.

Este caudal de anhelos ciudadanos que representaban los medios de comunicación regionales chocaba con la presencia cotidiana de hechos violentos a lo largo del departamento de Caldas. Los mismos periódicos denunciaban la llegada y asentamiento de los exilados del occidente del departamento a la ciudad de Pereira ${ }^{117}$ tras asesinatos, robos de cosechas, extorsiones y amenazas. Esta situación neurálgica hizo que El Diario se alineara en favor del Gobierno militar y del presidente Gustavo Rojas Pinilla, al solicitar el nombramiento de alcaldes militares en todas las poblaciones del occidente ${ }^{118}$ y reuniones con los exilados en el Batallón San Mateo de la ciudad, para que conocieran de primera mano la situación de dicha población ${ }^{119}$.

Así, se realizó una campaña diaria en favor de este personaje y se publicó una visita que tendría lugar en la ciudad el 31 de agosto de 1953. Además del apoyo al Gobierno, se pedía la ocupación de los militares en todas las ramas del poder público

115 El Diario [Pereira], 15 de julio de 1953: 4. 116 El Diario [Pereira], 29 de julio de 1953: 4. 117 El Diario [Pereira], 24 de julio de 1953: 8. 118 El Diario [Pereira], 23 de julio de 1953: 1 119 El Diario [Pereira], 5 de agosto de 1953: 1. 
del departamento, al argumentar que los caciques y gamonales de los pueblos, en muchos casos autores de la violencia, eran quienes controlaban las alcaldías y los juzgados municipales y no comprendían el cambio ocurrido en el país con el golpe de Estado a Laureano Gómez ${ }^{120}$. Solo con los militares en todos los cargos públicos, la nación podía llegar a tener una «revolución de orden moral» que pacificara el país y trajera consigo el regreso de la democracia ${ }^{121}$. De forma insistente, los liberales apelaron al llamado de estos sujetos al poder; base de la pacificación del país. Así lo dejaban claro:

Es imposible que gentes que otrora hacían alarde los sistemas de planchamiento y de un odio contra ciudadanos que no pertenecían al partido de gobierno, puedan seguir disfrutando posiciones en el nuevo gobierno... La total pacificación del departamento no se logrará sino a base de autoridades militares, no descansaremos de repetirlo ${ }^{122}$.

Esta posición del periódico liberal a favor del Gobierno militar contrastaba con los ataques constantes en contra del Partido Conservador, toda vez que en aquel momento el gobernador del departamento de Caldas era Fernando Londoño y Londoño, dirigente de esta línea política con gran influencia nacional, quien recientemente había sucedido a José Restrepo Restrepo, el cual renunció una semana después del golpe de Estado. Al mismo tiempo que se exigía la presencia de los militares en los cargos públicos, se señalaba a León María Lozano y a Gustavo Salazar García, conservadores del Valle del Cauca, como los autores materiales de las incursiones violentas de los pájaros en las regiones del Quindío y del occidente de Caldas ${ }^{123}$. Además, durante este mes de julio El Diario informó del cierre del periódico El Siglo en Bogotá —el cual era propiedad de Laureano Gómez- por traición a la patria y violación a la censura previa

120 El Diario [Pereira], 4 de julio de 1953: 5; El Diario [Pereira], 8 de julio de 1953: 8.

121 El Diario [Pereira], 1 de agosto de 1953: 4.

122 El Diario [Pereira], 8 de agosto de 1953: 4.

123 El Diario [Pereira], 10 de julio de 1953: 1. 
existente en el momento ${ }^{124}$, sin asumir la defensa de la libertad de prensa. Suceso que sugiere algún nivel de sectarismo político entre la misma prensa nacional.

Detrás de estas denuncias yacía una disputa política bipartidista donde los señalamientos entre liberales y conservadores iban y venían en las páginas de los dos principales periódicos de Caldas. Una de las primeras tensiones en torno al llamado de los militares a ocupar los cargos ejecutivos del departamento se dio entre el gobernador, Fernando Londoño, y el director de El Diario, Emilio Correa Uribe. En una carta fechada el 29 de julio Londoño le comunicó a Correa lo siguiente respecto al pedido de un gobernador militar:

Me siento muy complacido como periodista que he sido y como devoto defensor de las libertades públicas de que la práctica inexistencia de la censura les haya permitido hacer el despliegue del 23 de junio en demanda de un gobierno militar para Caldas, tesis del diario LA PATRIA de Manizales proclamada ya varias veces desde esa alta tribuna del periodismo... Pero debo recordarles que la decisión en estas materias no corresponde a lo que equivocadamente se llama entre vosotros la opinión pública y que a veces no es sino la expresión privilegiada de innobles resentimientos... Sírvanse ustedes, haciendo uso de una libertad que no les será recortada, puntualizar exactamente los cargos contra mi administración. Decir en qué ciudad y por quiénes se están cometiendo atropellos contra los ciudadanos en sus personas o en sus bienes y cuáles son los casos de intranquilidad general, que mueven a su juicio a la opinión para solicitar un cambio de gobierno... Lo que sí es la verdad que tengo la idea de que el actual gobierno no encuentra necesario subvertir el orden constitucional ni el sistema de las leyes, ni el régimen de las ideas esenciales que dominaban en el país el 13 de junio, por voluntad libremente expresada de la opinión nacional ${ }^{125}$.

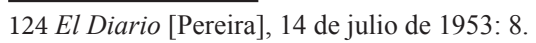

125 La Patria [Manizales], 1 de agosto de 1953: 1. 
La respuesta no se hizo esperar y apareció el 31 de julio en el periódico pereirano, en contra del Gobierno a nivel departamental, responsabilizando a los conservadores como los causantes de la violencia y del nivel de degradación de la vida del país. Uno de los señalamientos puntuales más fuertes desde esta ciudad - tal y como lo había solicitado el gobernador Londoño Londoño en su carta- se refirió al asesinato del joven liberal Ayán Cano Cano tras visitar una de sus propiedades familiares en el municipio de Santuario, pues él y sus padres se encontraban «exilados» en Pereira por la violencia bipartidista ${ }^{126}$. En la editorial de dicho día, titulada «Puntualicemos», se manifestaba el descontento con el primer mandatario caldense, tras dicho asesinato, en los siguientes términos:

¿Quiere asegurarnos el señor Doctor Londoño y Londoño que a las poblaciones del occidente caldense puede llegar tranquilo y sin temores, ni sobresaltos, un hombre que esté ideológicamente compenetrado con el estado de cosas? Porque, sería, quizá, pensar en lo absurdo, considerar que a esos pobres y desventurados poblachos pueda acercarse un individuo que tenga ideas liberales, pues que entonces es con su vida que debe pagar el acceso a cualquiera de esos lugares... Y podría decirnos el señor Doctor Londoño y Londoño si a esos mismos pueblos que son la parte neurálgica de Caldas han regresado ya los miles de exilados [sic] que tuvieron que abandonar sus parcelas... para no pagar con sus vidas el "delito" de pensar diferentemente de cómo piensan los hombres que sirvieron el 13 de junio ${ }^{127}$.

Por su parte, El Diario de Pereira continuó su campaña progobernador militar en Caldas y publicó, los días 3 y 8 de agosto, editoriales tituladas «Seguimos puntualizando» e «Insistimos», en las cuales se solicitaba la llegada de militares a la gobernación de Caldas y a todos los municipios del departamento como fórmula de pacificación de la región y del retorno a la democracia paritaria

126 El Diario [Pereira], 27 de julio de 1953: 8.

127 El Diario [Pereira], 31 de julio de 1953: 4. 
y sin sectarismos. Sin embargo, aunque en efecto fue nombrado gobernador de Caldas el coronel Gustavo Sierra Ochoa en septiembre de 1953, lejos estuvieron de terminarse las disputas políticas en el departamento, pues con el transcurrir del régimen militar, la prensa regional intervino a favor o en contra de los intereses políticos de militares y de los partidos.

\subsection{La disputa en la prensa caldense por el régimen militar a nivel nacional y regional}

En 1954 el apoyo de la prensa caldense al régimen militar se mantuvo, aunque no sobra decir que - con ciertas reservas y recelos-, tal y como se puede observar en las noticias publicadas, que daban cuenta del desarrollo de la relación de los partidos con las Fuerzas Armadas. En este año, Rojas Pinilla convocó la ANAC en el mes de abril y estableció que las condiciones de orden público del país no garantizaban la celebración de elecciones, además decretó la proscripción del Partido Comunista e implantó los consejos administrativos departamentales y municipales en reemplazo de las Asambleas y Concejos ${ }^{128}$. En medio de este proceso y en el mismo mes, el expresidente Alfonso López Pumarejo marcó la iniciativa al buscar el apoyo completo de los liberales hacia el presidente Gustavo Rojas Pinilla. Sus primeros planteamientos remarcaron que dicho apoyo al Gobierno no significaba la renuncia a sus derechos políticos y la solicitud de establecer una paridad entre los integrantes de la $\mathrm{ANAC}^{129}$. En este mismo sentido se pronunció la prensa liberal adhiriéndose a lo planteado por López Pumarejo, pues las Fuerzas Armadas podían tener el apoyo completo de los liberales de forma desinteresada, siempre y cuando los militares no se apartaran del lema de su gobierno: «Paz, Justicia y Libertad». El liberalismo apoyaba al régimen con base en dichos principios y no por «el fulgor de sus espadas» ni por el «brillo de sus charreteras» ${ }^{130}$. A finales de

128 Palacios, Entre la legitimidad..., 214.

129 El Diario [Pereira], 3 de abril de 1954: 1.

130 El Diario [Pereira], 11 de abril de 1954: 4. 
abril, la Comisión de Acción Política del Liberalismo, declaró lo siguiente: «... el partido ha prestado y continúa dispuesto a prestar al Presidente de la República todo el apoyo y cooperación que necesite» en aras de contribuir al afianzamiento de la paz, la restauración del orden democrático y la convivencia de todos los colombianos $^{131}$.

Sin embargo, hacia mediados de 1954, este amparo se empezó a agrietar. A pesar del aval a las Fuerzas Armadas sostenido con la declaración conjunta de los dos directorios políticos nacionales, en respaldo a la convocatoria de la $\mathrm{ANAC}^{132}$, la solicitud de participación de ambos partidos en la misma y la defensa del régimen en la masacre a los estudiantes universitarios del 8 y 9 de junio, El Diario señaló la influencia de elementos del viejo régimen en el nuevo gobierno militar. En este sentido, el apoyo a Rojas Pinilla por parte de los liberales se fracturó por la conformación de la Asamblea Nacional Constituyente y el número de delegados con los cuales contó este partido ${ }^{133}$.

Hacia agosto, luego de que la ANAC reeligió en su cargo como presidente de la República al general Gustavo Rojas Pinilla con sesenta y ocho votos a favor, El Diario hizo eco de las declaraciones de El Espectador en Bogotá al decir:

El partido liberal no podía y no debió de admitir nunca la posibilidad de asistir a la Constituyente en condiciones de inferioridad respecto de un adversario que recurre a todos los extremos para conservar el poder, precisamente porque está seguro de que es una minoría irremediable... Nuestra posición será de patriótica y respetuosa expectativa. Estamos dispuestos, como lo estuvimos siempre hasta el 8 de junio de 1954, a aplaudir todos sus actos de gobierno y todas sus manifestaciones en cuanto ellos contribuyan al afianzamiento de la paz, al restablecimiento de las libertades esenciales y, en fin, a la restauración de los

131 El Diario [Pereira], 27 de abril de 1954: 4.

132 El Diario [Pereira], 8 de junio de 1954: 1.

133 El Diario [Pereira], 9 de junio de 1954: 4; El Diario [Pereira], 10 de junio de 1954: 4. 
auténticos sistemas democráticos. Pero igualmente y dentro de la libertad de prensa incompleta que hoy rige, criticaremos todas [sic] medida, toda decisión y toda declaración oficial que contradiga los postulados conocidos de Paz, Justicia y Libertad ${ }^{134}$.

A nivel regional, otro punto de observación posible para diferenciar la cobertura periodística del régimen se dio en la contrastación entre la postura crítica liberal de El Diario y el apoyo conservador de El Diario del Quindío a partir de la reelección de Rojas Pinilla, lo cual demuestra la disputa dinámica de las tres ciudades principales a nivel departamental respecto a la obra administrativa de los militares. De este modo, el mandato del coronel Sierra Ochoa fue evaluado desde distintas perspectivas, puesto que, para este primer periódico, la administración se enfocaba solo en beneficio de Manizales y, para los segundos, la región del Quindío había visto un cambio total a cerca de las anteriores administraciones.

Figura NRo. 9. Portada Diario del Quindío.

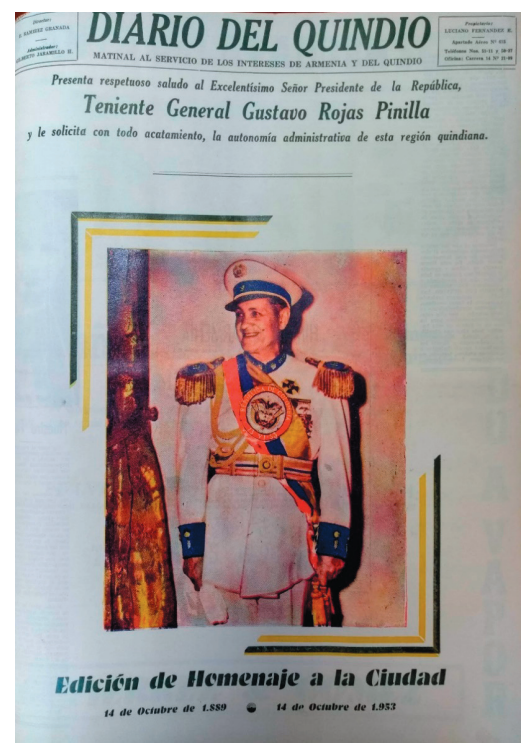

Fuente: Diario del Quindío [Armenia], 14 de octubre de 1953.

134 El Diario [Pereira], 5 de agosto de 1954: 4. 
Las críticas a los militares desde la prensa liberal de Pereira iniciaron con motivo de la publicación de las obras a realizarse para la celebración del Cincuentenario de Caldas durante el año de 1955. Emilio Correa Uribe, en una editorial que tituló «La Eterna Historia», criticó al Coronel Gustavo Sierra Ochoa, gobernador del departamento, pues el anuncio de la construcción del Teatro Municipal, el Hotel de Turismo y el Instituto Universitario de Caldas - todos ellos en Manizales - era la demostración de que para el primer mandatario no existía el resto del departamento. Así se lo hizo saber públicamente:

La historia no ha cambiado en lo más mínimo y bajo el gobierno del señor coronel Sierra Ochoa, como bajo todos los que ha tenido Caldas, desde el año de 1905, el criterio de los mandatarios es absolutamente igual; Caldas no existe y solamente hay una cosa llamada Manizales... [sic] Y Pereira y Armenia, y Calarcá y Riosucio, ¿y Salamina y La Dorada? Eso no existe; al menos no existe para el señor gobernador de Caldas, coronel Sierra Ochoa ${ }^{135}$.

Mientras tanto, en Armenia, el Diario del Quindío, periódico de tendencia conservadora oficialista, resaltaba la labor de Sierra Ochoa. Durante el mes de octubre de 1954, varias noticias y editoriales destacaban el amplio respaldo que este diario otorgó al régimen militar. En primer lugar, en sus páginas se informó que el Gobierno de Caldas había levantado la censura en contra de este medio de comunicación tras las gestiones realizadas por el mayor Carlos Alberto Dousdebés, comandante del Batallón Cisneros, en favor de dicha casa periodística ${ }^{136}$.

A la semana siguiente, tras la visita de dicho gobernador, acompañado por su esposa y varios secretarios de despacho, a la región del Quindío, el seguimiento periodístico en favor del burgomaestre fue extenso. El titular en primera plana del lunes 4 de octubre fue: «Se ha iniciado una nueva política administrativa en

135 El Diario [Pereira], 28 de junio de 1954: 4.

136 El Diario del Quindio [Armenia], 1 de octubre de 1954: 1, 8. 
beneficio de Armenia y todo el Quindío». La crónica periodística detalló la recepción hecha por las autoridades militares, civiles y eclesiásticas del Quindío en el aeropuerto El Edén en donde se le ofreció una copa de champaña a los visitantes, para luego dirigirse a un almuerzo campestre en la hacienda El Cabrero y finalizar con un baile en el Club América de la ciudad de Armenia antes de regresar a Manizales ${ }^{137}$. Durante su estancia el coronel Sierra Ochoa se dirigió a los habitantes del Quindío y aseguró que su Gobierno no era uno de tipo centralista y que todos los municipios de Caldas eran importantes para la Gobernación. Estos elementos de su intervención guardaron clara relación con la campaña esgrimida desde Pereira en meses anteriores, en la cual se señaló que las principales inversiones del departamento eran solo para la ciudad capital. En uno de sus apartes, el coronel Sierra Ochoa expresó lo siguiente:

Nunca he pensado en orientar migobierno por cauces regionalistas, ya que solo me ha animado el deseo vehemente de laborar por Caldas y para Caldas. Todas las regiones, ciudades, veredas han recibido dentro de las posibilidades fiscales del departamento el apoyo necesario. Ahora se ha iniciado la época del municipio de Caldas, y no cesará un solo instante en esta labor, porque mi empeño radica en la atención a los municipios... Si se han dado a conocer palabras de torcida interpretación, debo declarar que ellas no representan ni interpretan el sentido de mi gobierno ${ }^{138}$.

La propia defensa de la labor administrativa de la gobernación continuó en Manizales, lo que fue registrado por El Diario del Quindio al referir una nota hecha al gobernador por La Patria, en la cual hacía un recuento de los programas y las obras que venía adelantando la administración departamental en favor de la ciudad de Armenia y el Quindío. En la entrevista, Sierra Ochoa reseñó el programa de electrificación con el apoyo de la Central Hidroeléctrica de Caldas y el Banco Nacional del Café por 600

137 El Diario del Quindio [Armenia], 4 de octubre de 1954: 1.

138 El Diario del Quindio [Armenia], 5 de octubre de 1954: 1, 8. 
000 dólares a favor de la ciudad de Armenia; el plan de carreteras del Quindío con la elevación de aportes de 7000 a 20000 pesos mensuales, con los cuales se había dotado a la región de volquetas, motoniveladoras y maquinaria para el mantenimiento de las vías; y el mejoramiento de la Casa de Menores y la Casa Correccional. En consideración del Gobernador, esto demostraba que la política de su gobierno tenía como centro primordial la vigorización de todos y cada uno de los municipios de Caldas, tal y como lo había expuesto el presidente Rojas Pinilla con la tesis del fortalecimiento de la vida de los municipios ${ }^{139}$.

Toda esta labor fue alabada en dos editoriales del periódico del Quindío, en las cuales se indicó el gran cambio en la administración pública que marcaba a las Fuerzas Armadas al mando del poder regional. Para el editor Bernardo Ramírez Granada, la notable mejoría del orden público en las zonas rurales quindianas era un hecho incuestionable; el Ejército como guardián de la tranquilidad había restaurado el orden ${ }^{140}$. Dicho cambio era obra de la nueva administración racional y política de los militares, quienes trabajaban por la transformación material y la conciliación espiritual de Armenia y el Quindío bajo el signo del progreso, a diferencia del abandono oficial de todas las administraciones pasadas ${ }^{141}$. De esta forma, puede entenderse la aclamación mesiánica que Vicente Giraldo, reconocido empresario de la ciudad, le dedicó al presidente en su visita el 18 de octubre en el Teatro Bolívar, día del aniversario de Armenia:

Excelentísimo señor: Todos los habitantes del Quindío y en especial los armenios, esperábamos vuestra visita como esperaban los peregrinos de Jerusalén la llegada del Mesías. Jesucristo hizo su entrada triunfal a Jerusalén entre las muchedumbres que portaban palmas y cargando el Divino Redentor en un humilde asno. Pero los tiempos han cambiado y vos, excelencia, habéis llegado por los aires como un ángel con grandes alas, surcando

139 El Diario del Quindio [Armenia], 8 de octubre de 1954: 1, 8.

140 El Diario del Quindio [Armenia], 5 de octubre de 1954: 4.

141 El Diario del Quindio [Armenia], 8 de octubre de 1954: 4. 
los cielos de Colombia en vuestra nave aérea que se envolvió en nubes blancas como las que envolvieron el Divino cuerpo del Señor cuando resucitó y ascendió a los cielos. Así habéis realizado vuestra entrada triunfal a Armenia, como si fuerais un guerrero de la legendaria Roma regresando triunfal de la batalla. Y es que vuestra excelencia está también librando un gran combate contra los malos colombianos y en busca de conseguir el imperio de la paz, la justicia y la libertad, emblema sagrado de vuestro gobierno ${ }^{142}$.

\subsection{Adhesión conservadora y disidencia liberal al régimen a nivel periodístico}

A inicios de 1955, el presidente Rojas Pinilla anunció la continuidad del estado de sitio y la intervención en los medios de comunicación como la prensa y la radio para difundir de forma oficial las opiniones de las Fuerzas Armadas, lo cual desgastó rápidamente la imagen popular de los militares ${ }^{143}$. En mayo de dicho año, la cuestión fundamental para el conservatismo caldense consistía en consolidar la unión de sus distintas facciones, para lo cual se declaraba el apoyo al régimen militar por las afinidades ideológicas existentes. Así lo dejaba saber La Patria en una columna de opinión titulada "Unión o catástrofe», en la que se puede leer el apoyo a las fuerzas armadas al expresar lo siguiente: «... este (gobierno) ha dado sobradas demostraciones de su arraigada fe conservadora y de su profundo respeto y acatamiento a las doctrinas católicas, apostólicas y romanas» ${ }^{144}$.

De hecho, varios dirigentes conservadores del departamento, en notas periodísticas publicadas a lo largo de mayo de dicho año, hicieron un llamado constante a la unión del Partido y el apoyo indiscutible al gobernador Sierra Ochoa y al presidente Rojas Pinilla. Entre los conservadores que sostuvieron esta posición

142 El Diario del Quindio [Armenia], 20 de octubre de 1954: 5.

143 Palacios, Entre la legitimidad..., 214-215.

144 La Patria [Manizales], 3 de mayo de 1955: 5. 
estaba Juan Botero Trujillo, alzatista ${ }^{145}$, oriundo del municipio de Neira, quien solicitaba la unidad conservadora alrededor del Gobierno militar y decía:

La adhesión del conservatismo al gobierno de las Fuerzas Armadas debe ser sincera y leal, ya que es un gobierno nuestro que obra y opera con hombres de nuestra colectividad y con los fundamentos filosóficos que alientan al partido conservador colombiano. Olvido de toda diferencia ${ }^{146}$.

De igual manera se pronunció Luis Carlos Giraldo, líder conservador de Manzanares, al decir que la adhesión a los militares era una necesidad imperiosa para los conservadores. Incluso sostuvo la idea de creación de un órgano periodístico para el régimen dictatorial al expresar lo siguiente:

En primer lugar, es bueno establecer previamente que la adhesión conservadora al régimen de las Fuerzas Armadas no es sólo [sic] una imperiosa, urgente e incontrastable necesidad, sino un deber impostergable e ineludible. Aún más: [sic] estimo que el partido conservador tiene frente al actual gobierno una deuda incancelable [sic] de gratitud y lealtad... Con el mismo derecho con que los partidos políticos fundan editoriales para propagar sus ideas y las casas comerciales para afamar sus productos y las asociaciones religiosas para conseguir prosélitos y las academias para dar a conocer sus labores, etc. [sic], puede el gobierno organizar un periódico para defender ante la opinión pública y frente a la oposición, su gestión administrativa. Si el gobierno tiene el derecho y la obligación de defenderse con las armas de los facciosos que en el Tolima atentan contra la paz pública, también debe tener el derecho para, desde el campo meramente intelectual, defender su obra de gobierno ${ }^{147}$.

145 Los alzatistas estaban liderados por Gilberto Álzate Avendaño y conformaban una de las facciones más fuertes al interior del conservatismo colombiano. Caldas era el departamento con mayor presencia de dicha facción en el territorio nacional.

146 La Patria [Manizales], 4 de mayo de 1955: 1.

147 La Patria [Manizales], 7 de mayo de 1955: 1. 
El mismo Giraldo, una semana más tarde, con motivo de la celebración del cincuentenario de la creación del departamento de Caldas, defendió la labor realizada por el coronel Sierra Ochoa en su cargo como gobernador, lo cual empezaba a marcar una tendencia dentro del conservatismo caldense respecto del Gobierno militar, en donde se asimilaba y se comparaba la ideología de conservadores y militares, al tiempo que controvertía a los críticos del mismo Gobierno. Así se comentaba la situación:

Las generaciones futuras no podrán desconocer que el gobierno de Sierra Ochoa ha estructurado su obra bajo los auspicios del contenido doctrinario bolivariano y católico que preside al partido conservador y al Gobierno de las Fuerzas Armadas.... Está bien que existan discusiones en torno a la eficacia del gobierno de Sierra Ochoa porque este es un derecho democrático, de libre controversia pública, sin penumbras desdorosas. Lo que si resulta paradójico es que un gobernante, con su temperamento y sus condiciones militares, tenga que rendir cuentas al resentimiento, a la politiquería y al odio ${ }^{148}$.

De hecho, algunas de las críticas provenientes desde el propio conservatismo fueron atacadas sin descanso en Caldas. Los partidarios conservadores en este departamento cerraron filas en torno a la figura de Sierra Ochoa, al defender al régimen de toda crítica pudiera surgir al interior del propio conservatismo, como ocurrió con lo dicho por un jefe nacional como Belisario Betancur, quien ponía en entredicho la gestión del gobernador militar en su revista Unidad. Esto refleja niveles de tensión intrapartidista, desde instancias nacionales a niveles locales, y cómo los medios de comunicación eran un escenario activo - $\mathrm{y}$ de mucha circulación- que develaban estas disputas al mostrar la agenda de ciertas facciones. José Jesús Jaramillo, funcionario del régimen militar, defendía así al Gobierno caldense:

148 La Patria [Manizales], 11 de mayo de 1955: 5. 
Se me dio a conocer el número 34 de "La Unidad", semanario bajo su inteligente dirección. "Caldas, paraíso perdido por la administración”, es el título de la página que allí se le dedica al coronel Sierra Ochoa, en su calidad de gobernante de este departamento. Después de aludir a diversos aspectos de la administración pública, de derramar bilis contra el mandatario.... negamos todo derecho a quienes tratan de descalificarnos y tratan de desprestigiar un gobierno tan conservador, tan ecuánime, tan recto y activo como fueron los anteriores ${ }^{149}$.

Para acallar estas voces disonantes, el Directorio Nacional Conservador definió su postura a través de un comunicado en el que hizo un llamado a la unión del partido y a la legitimación del Gobierno de las Fuerzas Armadas, ya que la coincidencia doctrinaria que alimentaba al mandato de Rojas Pinilla se equiparaba a la ideología conservadora. Además, la comunicación llamó la atención en el sentido que la crítica al Gobierno era, cuando menos, una traición a la patria. Así, se descalificaba cualquier tipo de oposición por atentar contra la sacra unidad nacional que representaba el Gobierno militar, tal como lo muestra el siguiente apartado:

El Directorio Nacional Conservador juzga necesarias las siguientes declaraciones: El Directorio reafirma su concepto que la línea política que se debe seguir es la de consolidar la unión conservadora y continuar la norma de respaldo al gobierno. El jefe del estado [sic] respeta las tradiciones colombianas que el partido conservador ha defendido; mantiene el reconocimiento efectivo de todas las garantías y prerrogativas de la iglesia católica como religión de la nación; estimula con empeño perseverante la convivencia civil entre los colombianos, para que las campañas partidistas no se conviertan en conflictos violentos; recalca en el principio de que los servidores del Estado tienen que serlo de todos los colombianos, y lleva a la práctica, con ideas conservadoras y con hombres conservadores, las múltiples iniciativas de su gobierno. Si en esa forma se interpretan y practican los programas conservadores de las distintas épocas, es claro que nuestra

149 La Patria [Manizales], 12 de mayo de 1955: 5. 
doctrina constituye el sólido fundamento de cuanto empeño realicemos en favor del gobernante y de la misión altísima que la Asamblea Nacional Constituyente hubo de encomendarle... Una labor de oposición es la mejor colaboración que pueden ambicionar quienes han llevado la ruina y la orfandad a muchos hogares, luchando por destruir la pacificación alcanzada como fruto de los nobles esfuerzos del gobierno, que no despreció ninguno de los recursos aconsejados para conquistarla... El Directorio considera que una campaña de oposición sólo [sic] se comprendería hoy como determinada por consideraciones personalistas y por ello en pugna con los postulados ideológicos del programa conservador ${ }^{150}$.

En contraposición al apoyo conservador hacia Sierra Ochoa y Rojas Pinilla, las relaciones del régimen con la prensa liberal se deterioraron aceleradamente. Las primeras señales del divorcio entre las Fuerzas Armadas y el liberalismo se encuentran en varios asuntos ocurridos en 1955. Desde la perspectiva liberal, la figura de los militares como salvadores de la patria se fue derrumbando por la participación de los conservadores en el Gobierno de Rojas Pinilla y las denuncias de la ausencia de liberales en cargos administrativos en dicho régimen. Limitados por la censura de prensa, las críticas al Gobierno militar siempre se enfocaban en la influencia del conservatismo al interior de la dictadura. Así lo planteó El Diario al manifestar que el sectarismo político era el principal causante de las desgracias nacionales, pero que la solución de esta cuestión no les atañía tan solo a los partidos con sus afiliados

... el gobierno pierde autoridad para combatirlo si al propio tiempo que lo condena, discrimina entre patriotas para distribuir los beneficios de la administración pública... En la empresa de luchar contra el sectarismo sería muy útil de acostumbrar a los conservadores a ver caras liberales en los puestos de la administración pública ${ }^{151}$. 
En este sentido, los días 22 y 23 de junio desde Pereira, Emilio Correa Uribe reprodujo dos editoriales de El Espectador y El Tiempo, en las cuales se tensionaban las relaciones con el régimen militar. En el primer artículo puso sobre aviso a los conservadores por las críticas y señalamientos que los militares hacían a ambos partidos, a pesar del apoyo de estos últimos al régimen, y a la vez cuestionó frontalmente un mensaje del coronel Sierra Ochoa en el que se utilizó la etiqueta de conspiración para aquellos que desearan un cambio de mando político. Respecto a lo primero, les recordaron a los conservadores la actitud de su partido, la cual «...con verdadera abnegación sigue declarándose partido de gobierno, como si los ataques y los agravios de que a las dos colectividades políticas se hace objeto de personajes como el coronel Sierra Ochoa no los alcanzasen ${ }^{152}$. Sobre este personaje, la publicación mencionó:

Cabe recordar que el señor Gobernador [sic] de Caldas, en su ya célebre discurso declaró lo siguiente: Pensar en la entrega del mandato ejecutivo cuando tenemos la certeza de que el sucesor no tiene ni la nobleza, ni la visión profética del mando, es conspirar abiertamente contra los intereses de la patria ${ }^{153}$.

La segunda editorial, escrita por Calibán (Enrique Santos Montejo), en su distinguida columna «Danza de las Horas», fue una respuesta a un mensaje de Sierra Ochoa transmitido por la Radiodifusora Nacional. En su columna de opinión, Santos le recordaba al gobernador caldense que su estancia en el poder era provisional y que era un imperativo retornar a la Democracia. A continuación, se cita en extenso la editorial para demostrar el talante y el tono de la disputa del liberalismo con el régimen en ese momento:

El señor coronel Sierra Ochoa, gobernador de Caldas, en ardiente arenga conmemorativa del primer cincuentenario de la creación del departamento de Caldas, se dejó arrastrar por el demonio de 
la elocuencia... Está bien y es justo el elogio a cuanto ha realizado el gobierno en el sentido de restablecer la paz, impulsar las obras públicas, favorecer a las clases trabajadoras, y otorgar garantías de que en muchos departamentos se disfruta; pero va demasiado lejos, demasiado aprisa el coronel cuando trata como traidores a la Patria, y conspiradores a quienes piden el retorno a la normalidad... Regresar a la normalidad no es conspirar. Es querer que seamos otra vez lo que fuimos hace diez años. Edén político. Retornar a la normalidad, señor coronel Sierra, no es un crimen. Es la más patriótica y fecunda de las aspiraciones racionales. Desconocerla, sí que es traicionar los verdaderos intereses de la patria. La arenga de mi coronel Sierra Ochoa, suscita otra cuestión, que debe quedar fijada en forma precisa. El movimiento del 13 de junio no se hizo contra todo eso de que habla el coronel. Es decir, contra los partidos tradicionales. Contra el ejercicio de la democracia. Contra los discursos. Ni contra los llamados tahúres electorales, gracias a los cuales, entre otras cosas, el conservatismo tomó el poder, como lo había tomado antes el liberalismo. Se hizo contra un régimen que precisamente había suprimido la política, los discursos y el juego electoral, para reemplazarlo con la oposición y la violencia. El teniente general y presidente Rojas Pinilla definió desde el primer día, y lo ha reafirmado en cien discursos de noble inspiración, el programa del 13 de junio: "No más sangre. No más persecuciones. Colombia para todos los colombianos. Restauración de las instituciones democráticas". No pedimos más. Y por pedirlo, el coronel Sierra Ochoa, nos califica de subversivos. La subversión consistirá más bien, en renegar de los principios de junio y pretender que la misión transitoria confiada a las fuerzas armadas se convierta en permanente dominio antidemocrático ${ }^{154}$.

El siguiente choque de los medios de comunicación liberales con el Gobierno militar - el mismo que con tanto ahínco habían defendido recién ocurrido el golpe de Estado el 13 de junio de 1953 - ocurrió cuando en la conmemoración del segundo aniversario del golpe a Laureano Gómez, una editorial difundida de nuevo por la Radiodifusora del Estado y retransmitida en todas las cadenas radiales del país, declaró lo siguiente: 
El 13 de junio es un día memorable en que acontecimientos solemnes cambiaron el curso de la historia y cuyo sentido no puede torcerse porque la malevolencia que esgrime maza de piedra o puñales burdos, y de los saboteadores y fariseos, han de comprender que en la encarecida defensa de Colombia los militares cuentan con tres argumentos incontrovertibles: patriotismo, inteligencia y ametralladoras ${ }^{155}$.

En especial, el uso de la palabra «ametralladoras» fue tomado por la prensa liberal como una amenaza a la democracia. Entre el 24 y el 30 de junio, El Diario publicó en su página editorial una serie de textos editoriales tomados de otros periódicos copartidarios tales como El Espectador, La Tribuna de Ibagué y El Diario de Medellín, en los cuales manifestaban su inconformidad ante las ametralladoras del régimen ofrecidas como amenaza a los opositores. La primera editorial tomada de El Espectador apareció en la edición del 24 de junio 1955, con el título de «Las Armas y las Letras», y en esta se denunciaba la censura periodística «caprichosa y desconcertante» del Gobierno militar a los periódicos estudiantiles, al diario El Crisol de Cali y al radionoticiero La Opinión de Cúcuta. La crítica enfatizaba la cesión que los medios tenían que hacer al régimen para transmitir comunicados en los cuales se amenazaba a quienes no apoyaran la dictadura militar. En ella expresaban:

Últimamente hemos visto cómo se impone a las radiodifusoras de todo el país la obligación ineludible de ceder dos veces al día sus micrófonos para que desde ella se agravie a los colombianos en forma incalificable pero ya de sobra y merecidamente calificada por la opinión pública. El "editorial" de "Actualidad Nacional" del 13 de junio - no solamente no desautorizado sino explícita y entusiásticamente acogido por el señor presidente, lo que estimula y justifica los desmanes posteriores- y el que anteayer por la noche y ayer al mediodía transmitió ese órgano del Estado, muestran los extremos a los que se puede llegar con el encono contra una prensa que sin duda se ha equivocado pero de buena fe

155 El Tiempo [Bogotá], 15 de junio de 1955: 1, 21. 
y sobre todo en los últimos dos años no ha hecho sino colaborar en la forma más decidida y generosa al restablecimiento de la normalidad. (De El Espectador) ${ }^{156}$.

Al día siguiente, el 25 de junio, apareció en la sección editorial un texto de La Tribuna de Ibagué, la cual llevaba por título «Patriotismo y Ametralladoras» firmado por su editor, el periodista Héctor Echeverri Cárdenas. Dicho escrito era enfático en señalar que era inadmisible que dicha declaración oficial no fuese censurada por Rojas Pinilla, para que se supiera su postura respecto a la brutalidad de sus expresiones, ya que el primer mandatario de la nación no podía, en concepto del periodista, proclamar la apoliticidad del Gobierno y, al mismo tiempo, que sus colaboradores hicieran política partidista. La ferocidad de la crítica liberal quedó consignada en las siguientes palabras:

No entiende nadie eso del antisectarismo cuando es evidente que en la administración no hay sino laureanistas embozados. Nombrar un liberal, ni para que pensarlo... Valdría más en este caso que alguien se quitara la careta y le dijera al país: el poder es para nosotros solos y lo vamos a usufructuar por tiempo indefinido gústele a unos o desazone a otros. Y si no les agrada échense a la calle y protesten que con gritos no nos vamos a caer porque para eso tenemos cañones, tanques y ametralladoras... El radioperiódico oficial cuenta con las ametralladoras para imponerse como último "radio". Ya es bueno saberlo. Y que el ejército tomó el poder no para devolverlo al pueblo, cómo se le ofreció tantas veces sin estarlo pidiendo, también es conveniente que lo sepan todos. Y que cuando haya un reclamo popular contra cualquier injusticia, no habrá otra respuesta que esas mismas ametralladoras, no es improcedente que lo sepa el país. Héctor Echeverri Cárdenas (La Tribuna de Ibagué $)^{157}$.

La última editorial que tocó el tema de las ametralladoras del régimen, publicada el 30 de junio y titulada como «La Verdadera Democracia», fue tomada de El Diario de la ciudad de Medellín. 
Esta publicación señalaba a los conservadores del gobierno como los culpables del comunicado, sin dejar olvidar que el partido liberal contaba con las mayorías del pueblo a nivel nacional. Así lo manifestaba:

Es inexplicable que un radio periódico, representante de un mandatario civilizado y culto, desafíe a la opinión pública en la forma airada que lo ha hecho. Es que a estos godos los asfixia la paz y la tranquilidad, cuando estas no van encaminadas a conseguir sus proditorios fines... A ellos lo que les interesa es el poder por el poder mismo, para poder disfrutar a sus anchas de los presupuestos públicos...En cambio, los otros partidos, aunque tengan mayor número de votos y una excelente hoja de servicios a la república que se los lleve el diablo. Así razonan estos advenedizos de manga ancha, llamados a regir los destinos de este país por una malhadada división liberal, pero nunca por el poder incontrastable de las mayorías. Sépanlo bien. Gustavo Mejía Ángel. (El Diario de Medellín) ${ }^{158}$.

En el caso de la línea editorial propia de El Diario, las opiniones de Correa Uribe, a mediados de 1955, habían estado delineadas por el tema de la censura en Caldas y las relaciones de la prensa con el régimen. En este sentido, se entiende su seguimiento a los mensajes oficiales del Gobierno en los medios de comunicación y ciertas desavenencias tanto con el régimen militar y la prensa conservadora caldense. Respecto a los militares había elevado una queja con anterioridad en las páginas de su periódico, al señalar el trato inequitativo y distinto del Gobierno a las publicaciones partidistas:

Bajo el Estado de Sitio se ha dictado una interminable cadena de decretos-leyes, tendientes casi todos a exterminar o a limitar más de lo que ha sido, la libertad de expresión. Es de tal suerte cierto el enunciado, que, para escribirlo, simplemente, nos tiembla un tanto el pulso, ante el temor que mañana se nos diga a nosotros que abusamos y nos excedimos en la tolerancia de las leyes y las 
autoridades... Entonces meditemos un poco sobre la razón para el trato discriminatorio, con mucha más acentuación en provincia, en donde los periódicos de tremendo odio hacia el gobierno y sincero amor hacia el "gran exilado de España" como ellos mismos lo llaman, tratan sobre todos los temas... utilizando un estilo panfletario $^{159}$.

De igual forma se quejó del cubrimiento desmedido de $L a$ Patria al coronel Gustavo Sierra Ochoa durante la celebración del cincuentenario del departamento, como lo afirmó al escribir: «... recientemente, un periodista de La Patria de Manizales solicita que se muestre más todavía gobiernista de lo que ha sido, pues apenas se limitó a publicar el retrato del señor gobernador, unas treinta y dos veces» ${ }^{160}$. Ese tipo de seguimiento periodístico, según su concepción de la función de la prensa en la sociedad, ni le seducía, ni le convencía. Sus críticas en contra de cierto tipo de prensa se hicieron más mordaces y punzantes, y al mes siguiente, en una de sus últimas editoriales al frente de El Diario, Correa Uribe se fue lanza en ristre contra algunos tipos de periodistas a los cuales llamó "perros falderos», definiéndolos de la siguiente forma:

Perros falderos, pero ya de dos patas, son los que en ciertos lugares de regiones muy cercanas a las nuestras, cumplen la misión de periodistas que agitan la cola y abanican a todos los señores, lamiéndoles miserablemente dentro de una cobardía tal, que aquello debería producir tristeza, sino es que lo que realmente da, es asco... A diario repiten su cantinela y runrunean también su monorrítmico sonsonete, sin que jamás osen siquiera mostrar los dientes, porque se mueren de miedo. De físico miedo, por lo que puedan sufrir sus desvalidas humanidades y por lo que seguramente sufrirían sus bolsas... Para creer que esas musarañas que hoy se auto titulan periodistas, pueden llevar ese nombre que les queda ancho de cuello y fundillón de abajo, como decía el P. Ángel. Porque no son más que "perros falderos" que saben batir la cola y recibir la pitanza. [sic] No más! $!^{161}$

159 El Diario [Pereira], 4 de junio de 1995: 4.

160 El Diario [Pereira], 20 de junio de 1955: 4.

161 El Diario [Pereira], 5 de julio de 1955: 4. 
El distanciamiento y la crítica de los liberales al régimen militar, mediante la discusión partidista, vivió un punto álgido en la región con la ocurrencia de uno de los momentos más críticos del Gobierno de las Fuerzas Armadas en Caldas, tras el asesinato de Emilio Correa Uribe - director de El Diario- y su hijo Carlos Correa Echeverri, ocurrido el 8 de julio de 1955 en el municipio de Obando (Valle del Cauca), cuando regresaban a Pereira de un viaje a Cali. La versión publicada en la crónica periodística sobre el homicidio detalló que tras colisionar con un jeep, Correa Uribe e hijo fueron acribillados con armas de fuego por dos personas que descendieron del otro vehículo ${ }^{162}$. Algunas versiones señalan que los autores materiales, Guillermo Granada Galeano y Luis Lugo Valencia, eran sicarios de la banda de los hermanos Marcos y Onésimo Granada, de la localidad de Sevilla, y que dicho crimen fue organizado por León María Lozano, más conocido como «El Cóndor», y Gustavo Álvarez Villegas, pájaros conservadores del Valle del Cauca ${ }^{163}$. Al primero de estos, El Diario ya lo había sindicado como uno de los principales autores de la violencia en el Quindío y en el occidente de Caldas ${ }^{164}$.

Con ocasión de este asesinato, El Tiempo publicó una editorial titulada "Otra oscura tragedia», en la que denunciaban la ola de asesinatos políticos en contra de personajes liberales ocurridos en los últimos días en el Valle del Cauca. A la muerte de Emilio Correa Uribe y su hijo Carlos se sumaban los crímenes en contra de José Aguilera y Tito Uribe White en Caicedonia, José María Barrios en Buga y Pablo Rebolledo en Andalucía. Ese mismo día, en el municipio de Tuluá, un grupo de diez liberales envió la famosa «carta suicida», al alcalde de la población y al periódico $E l$ Tiempo, en la cual denunciaban los actos delictivos de León María Lozano. El 10 de julio fue asesinado uno de los firmantes de la carta, el señor Arístides Arrieta. Cuatro días más tarde, el 14 de ese fatídico mes de julio de 1955, el director del diario liberal de Ibagué La Tribuna, Héctor Echeverry Cárdenas, uno de los críticos

162 El Diario [Pereira], 9 de julio de 1955: 2.

163 Johnny Delgado Madroñero, El Bandolerismo en el Valle del Cauca, 1946-1966 (Cali: Secretaría Cultura Valle del Cauca, 2011), 64. 164 El Diario [Pereira], 10 de julio de 1953: 1. 
más fuertes de los militares, sufrió un atentado en su contra ${ }^{165}$. Las continuas denuncias de El Tiempo sobre estos ataques contra los liberales le costaron la censura total y el cierre de sus actividades por orden presidencial.

\subsection{El Binomio de Calarcá: la prensa regional del régimen y la sombra del pacto bipartidista}

Cuando se acercaba el final del periodo presidencial para el cual fue elegido Rojas Pinillas por la ANAC, los partidos tradicionales empezaron a moverse para pactar un acuerdo civil que les permitiera enfrentarse de nuevo en elecciones. En febrero de 1956, las diferentes fuerzas políticas del liberalismo se reunieron en una gran convención nacional en Medellín, de la que salió elegido Alberto Lleras Camargo, quien solicitó a los conservadores un candidato de unidad nacional para reemplazar a Rojas Pinilla. Alzatistas y ospinistas como estaban tan comprometidos con la Dictadura militar no atendieron al llamado, razón por la cual el liberalismo acudió a Laureano Gómez para plantear la unión de los dos partidos y exigir el retorno del gobierno civil. Como resultado de ello, Lleras Camargo viajó a España a visitar a Gómez y firmaron el comunicado de Sitges el 24 de julio de 1956. El binomio liberal-conservador buscaba ser más poderoso que el binomio Pueblo-Fuerzas Armadas ${ }^{166}$.

Ante esta sombra de un pacto bipartidista, el régimen castrense se confrontó directamente con ambos partidos. Fue así como en la conmemoración del tercer aniversario por haber llegado al poder, Rojas Pinilla hizo el lanzamiento de un partido militar conocido como la Tercera Fuerza o también como el binomio PuebloFuerzas Armadas ${ }^{167}$. En el departamento de Caldas se reflejó esta tensión entre bipartidismo y Gobierno militar. La aparición del

165 Héctor Echeverry Cárdenas sería asesinado dos años más tarde, el 14 de junio de 1957 en la ciudad de Ibagué.

166 Palacios, Entre la legitimidad..., 216.

167 Cesar Torres del Río, Colombia siglo XX. Desde la guerra de los mil días hasta la elección de Álvaro Uribe (Bogotá: Pontificia Universidad Javeriana, 2015), 185. 
semanario El Binomio. Pueblo y Fuerzas Armadas, en junio de 1956 en el municipio de Calarcá, era prueba de ello. Este impreso, favorable al régimen militar, postuló sus objetivos en su primera editorial de la siguiente forma:

Llenar en esta sección de la Patria un vacío de propaganda y defensa de los postulados y actos de gobierno de las Fuerzas Armadas [...] Por, sobre todo, prestar nuestro contingente modesto, pero decidido y ferviente, a la única causa que nos es común: la salvación de la Patria. Para ello... proclamamos desde ahora que las sagradas cúpulas de Roma vigilan nuestro espíritu y ardemos en la misma pasión que hizo milagros en la espada y mente cósmica del Libertador ${ }^{168}$.

El cumplimiento de estos objetivos fue visible en el primer número, pues en la sección llamada «Información departamental» enumeraron las obras adelantadas en territorio caldense; entre las que sobresalieron la celebración de las semanas cívicas; la entrega del Centro Nutricional Infantil de Calarcá; además de las bibliotecas de Neira, Filadelfia y La Dorada bajo la dirección de la Secretaría Nacional de Asistencia Social (SENDAS) ${ }^{169}$. En la misma dirección, dieron cuenta de los actos de conmemoración del tercer aniversario del 13 de junio, los cuales empezaron con un tedeum en la parroquia de Calarcá, seguido de la instalación de los óleos de los generales Rafael Reyes, Gustavo Rojas Pinilla y el del coronel Gustavo Sierra Ochoa en el salón principal del Concejo Municipal. Estos actos finalizaron con los discursos públicos emitidos desde los balcones del Club Quindío por parte del alcalde local, el teniente Miguel León Almonacid, y los abogados Horacio Naranjo Martínez y Carlos López García, con la asistencia de los estudiantes de las escuelas oficiales y los funcionarios de las entidades públicas ${ }^{170}$. A la par, el nuevo medio hizo un extenso cubrimiento discursivo del régimen para difundir el pensamiento ideológico de esta tendencia política, la cual se

168 El Binomio [Calarcá], 30 de junio de 1956: 3. 169 El Binomio [Calarcá], 30 de junio de 1956: 4. 170 El Binomio [Calarcá], 30 de junio de 1956: 7. 
alimentaba de la doctrina católica y la figura de Simón Bolívar. Se declaraba en sus páginas que con la llegada de los militares al poder habían muerto los gamonales y los caciques, quienes bajo un disfraz político predicaron el odio y la retaliación, llevando la masa ignorante al sacrificio ${ }^{171}$.

Figura NRo. 10. Portada de El Binomio. Pueblo-Fuerzas Armadas.

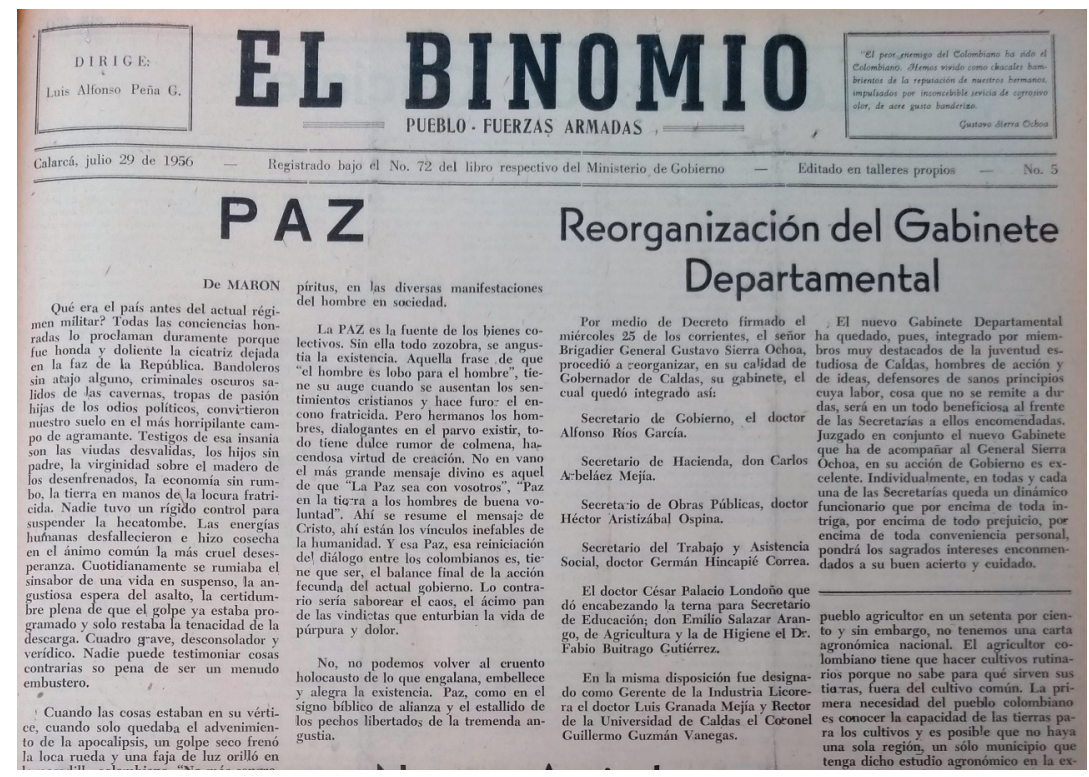

Fuente: El Binomio. Pueblo-Fuerzas Armadas [Calarcá], 29 de julio de 1956.

Meses más tarde, en agosto del mismo año, esta publicación periodística reprodujo dos mensajes del coronel Sierra Ochoa, en los cuales, tal y como lo había hecho el año anterior a través de la Radiodifusora Nacional, denunciaba la forma en que operaba la democracia bipartidista, aquella que el régimen militar con su obra de gobierno había superado. Primero apareció el siguiente mensaje dado por el Gobernador en la inauguración de los Juegos Atléticos Departamentales en Armenia:

171 El Binomio [Calarcá], 30 de junio de 1956: 7. 
El pueblo no tenía la libertad política que se hace figurar como bien supremo del pasado. Sus representaciones en los cuerpos colegiados nacían de punible ayuntamiento entre la voluntad de los poderosos electorales, los dirigentes intelectuales de la barbarie y sus autores físicos en las aldeas y poblados. El gobierno imponía, no solo la lista de elegidos, sino el castigo para los vencidos, la amenaza para los disidentes. El pueblo votaba bajo el apremio sentimental o la presión de los caciques. Y en los cenáculos periodísticos, en los clubes sociales se escogía a los cancerberos del parlamento, a los defensores de la mafia organizada ${ }^{172}$.

Semanas después, durante una visita al municipio de Chinchiná, continuó la arremetida del coronel Sierra Ochoa en contra de los partidos al decir:

Se necesita un espíritu generoso [...] ahora que los líderes de los partidos se lanzan por el camino de la subversión y de la rebeldía a embriagar a las masas con el licor oscuro de sus odios y el jugo venenoso de sus resentimientos; cuando los eternos enemigos se alían en la reconquista del poder, en la conjura contra la patria. Ya no son feroces rivales que, embanderados en la tradición, lanzaron a los hermanos contra los hermanos para satisfacer su gula y para alimentar su gloria con la sangre de los humildes [...] Sobre el siniestro pacto de los caudillos licenciados la matemática electoral hace sus guarismos. No se trata de la unión civil con el espíritu de un mejor servicio a la patria. Se trata de una unión innoble [...] en que cada uno de los firmantes conserva como el tramposo de feria, el as en la manga, el triunfo en la mano de tahúr, el puñal al alcance de la diestra ${ }^{173}$.

Estos agresivos señalamientos de los militares, a los partidos políticos y a los periódicos con tendencias partidistas, se dieron en un momento en el que dichos partidos comenzaban a entablar negociaciones para la restauración de las instituciones y la democracia. Así lo dio a conocer La Patria, en septiembre de 1956, cuando planteó que la unión conservadora era un hecho, pues las

172 El Binomio [Calarcá], 5 de agosto de 1956: 4.

173 El Binomio [Calarcá], 26 de agosto de 1956: 5. 
distintas facciones de esa colectividad emitieron un comunicado conjunto en el cual llamaban con urgencia al restablecimiento «... en el país del régimen democrático ${ }^{174}$.

\subsection{La caída de Rojas Pinilla y la legitimación del pacto bipartidista en la prensa caldense}

En el mensaje de año nuevo de 1957, el general Rojas Pinilla declaró que un nuevo orden republicano se abría paso en el país. Los comentarios en la prensa regional liberal y conservadora no demoraron en aparecer y emprendieron, desde sus páginas, la lucha contra los militares. Silvio Villegas comentó que ese nuevo orden, del cual hablaba el presidente, solo podría serlo si éste era «... sinónimo de adhesión al régimen representativo y el estado de derecho» ${ }^{175} \mathrm{y}$ no de las aspiraciones del general en reelegirse de nuevo. A la vez, para El Diario, el proclamado nuevo orden no era tan desconocido, pues no podían olvidar que aquellos políticos que tanto denigraban de los partidos políticos y de sus integrantes, antes de la dictadura, pertenecieron al conservatismo o al liberalismo. Así señalaron como «volteados», entre estos primeros, a Lucio Pabón Núñez, Gilberto Álzate Avendaño, Castor Jaramillo Arrubla y Luis Carlos Giraldo; por su parte, respecto a los segundos escribieron lo siguiente: «... no queremos ni podemos mencionar siquiera a los llamados "lentejos", que son quienes más gritan y berrean desde los puestos que a su traición han venido entregando a los mandones de la ANAC y de los consejos administrativos» ${ }^{176}$.

Días más tarde aparecieron voces discordantes entre el clero colombiano como las del Obispo de Ibagué, Monseñor Pedro María Rodríguez Andrade, quien manifestó: «... no es orden nuevo lo que necesitamos; lo que nos urge más bien es volver a los CAMINOS ANTIGUOS de nuestros mayores, quienes

174 La Patria [Manizales], 23 septiembre de 1956: 1.

175 El Diario [Pereira], 8 de enero de 1956: 4.

176 El Diario [Pereira], 8 de enero de 1957: 4. 
observaban con más rigor los divinos mandamientos y eran más auténticos cristianos» ${ }^{177}$. En resumen, desde la prensa regional, el denominado «nuevo orden republicano» era nada más que otro trasto inútil de la Dictadura tal como lo fueron otras iniciativas por establecer un proyecto político militar así como «la tercera fuerza», «el nuevo estilo» y «el MAN» ${ }^{178}$. Las Fuerzas Armadas ya no contaban con el beneplácito de muchos sectores de la opinión pública y mucho menos pudieron consolidar un movimiento político el cual agrupara una gran cantidad de simpatizantes a su favor.

Hacia finales de enero de dicho año, se dio un incidente que daba cuenta de la separación total de las facciones de los partidos respecto del régimen de Rojas Pinilla. El 24 de dicho mes, la revista norteamericana Time publicó un artículo titulado «Presidente de la Junta», en el cual informaba de una reunión secreta ocurrida en noviembre de 1956, entre altos funcionarios militares, con el ánimo de reorganizar la imagen de la Dictadura. Entre las exigencias formuladas al presidente por parte de los participantes de la reunión estaban una mayor libertad de prensa, el cierre de la Tercera Fuerza y, la más imperativa de todas, el abandono de cualquier proyecto de reforma constitucional que le permitiera a Rojas Pinilla reelegirse en el cargo ${ }^{179}$. La noticia fue desmentida por el general Gabriel París, quien sostuvo que la determinación de las Fuerzas Armadas era seguir en el poder para el periodo de 1958 a 1962.

Esta situación desató pronunciamientos en ambas toldas partidistas, en contra de la aseveración hecha por el general París. Mariano Ospina Pérez se mostró en desacuerdo con dichas declaraciones y denunció que los militares no podían deliberar en política, más aún cuando la Asamblea Nacional Constituyente no había tomado ninguna determinación sobre dicho tema.

177 El Diario [Pereira], 10 de enero de 1957: 4.

178 El Diario [Pereira], 10 de enero de 1957: 4.

179 El Diario [Pereira], 28 de enero de 1957: 1, 5. 
En este sentido, las declaraciones de los militares viciaban cualquier aspiración de reelección de Rojas Pinilla. Por su parte, Alberto Lleras Camargo concordaba con Ospina y recalcaba que la respuesta de los militares, al artículo de la revista Time, se convertía en una presión indebida para la ANAC y hacía que estos personajes se convirtieran en deliberantes, función que les estaba expresamente prohibida. Lleras tampoco dejó escapar la oportunidad para recordar la posición oficial del liberalismo: no se aceptaba la reelección del actual presidente ${ }^{180}$.

Al día siguiente, el Directorio Nacional Conservador, en cabeza de Guillermo León Valencia, se sumó a la exigencia del liberalismo y declaró su inconformidad con «la inmodificable determinación de las Fuerzas Armadas» sobre la reelección de Rojas Pinilla emitida por París. También manifestaba la disposición de ejercer sus derechos políticos y postular un candidato conservador para el próximo periodo presidencial ${ }^{181}$. Las aspiraciones de Rojas Pinilla por mantenerse en el poder hicieron que finalmente los ospinistas se integraran al frente civil, pues ante los intereses reeleccionistas de este, se disolvió la ANAC y se promovió la creación de una nueva asamblea compuesta por noventa miembros, de los cuales un tercio serían escogidos por el presidente ${ }^{182}$. A partir de esta fecha, la censura ejercida por la Oficina de Información y Prensa del Estado fue extrema y por esta razón los periódicos no pudieron cubrir los acontecimientos que dieron paso a la renuncia de Rojas Pinilla ${ }^{183}$. El 8 de mayo, la ANAC, en reuniones casi clandestinas, nombró de nuevo a Rojas Pinilla como presidente para el periodo de 1958-1962, lo cual fue declarado ilegitimo por la Iglesia ${ }^{184}$. Al fin, el 10 de mayo con su caída, la prensa pudo libremente anunciar el desplome del dictador.

180 El Diario [Pereira], 30 de enero de 1957: 1, 8.

181 El Diario [Pereira], 13 de febrero de 1957: 2.

182 Palacios, Entre la legitimidad..., 217.

183 Torres del Río, Colombia siglo XX..., 535 .

184 Jorge Orlando Melo, Historia mínima de Colombia (Bogotá: El Colegio de México, 2018), 229. 


\section{Conclusiones}

El estudiodela prensacaldensedurantela Dictaduradel general Gustavo Rojas Pinilla permite observar las disputas partidistas a nivel regional en torno a la organización política del país en dicha época. Un elemento destacable está relacionado con la concepción de los partidos sobre la transitoriedad del régimen militar, la cual fue difundida por la prensa entre sus copartidarios durante todo este periodo. Al inicio de la dictadura, el llamado de los militares como salvadores de la nación era funcional en tanto, al ocupar los cargos administrativos del Estado, se reinstauraría el orden y los partidos políticos trabajarían para eliminar los sectarismos políticos y así alcanzar la reconciliación nacional. De esta forma, los periódicos con sus respectivas adscripciones partidistas le dieron la bienvenida al régimen de las Fuerzas Armadas el 13 de junio de 1953. Además, las líneas editoriales de la prensa liberal y conservadora consideraban que esta ocupación del poder político estaba subordinada a los intereses de los partidos, principalmente al solicitar la conformación paritaria de la Asamblea Nacional Constituyente, entidad sobre la cual descansaba la hoja de ruta a seguir a nivel político. Con unas Fuerzas Armadas en el poder ejecutivo, el Congreso, las Asambleas, los Concejos cerrados, y una ANAC con una distribución equitativa, los partidos pensaban que el retorno a la democracia llegaría pronto.

Sin embargo, esta situación distaba mucho de la realidad, ya que, en primer lugar, para Rojas Pinilla no estaban dadas las condiciones necesarias por el estado de alteración del orden público que vivía el país y, en segunda instancia, la cercanía del régimen militar a las facciones ospinistas y alzatistas del Partido Conservador influenció la composición de la ANAC y dejó a los liberales como una minoría al interior de la misma. Con esta desigualdad en la participación de los partidos, en agosto de 1954 se volvió a elegir a Rojas Pinilla como presidente de la República para el periodo de 1954 a 1958. Esta situación marcó el distanciamiento de los liberales, los cuales — con el tiempo- 
irían agudizando sus críticas a los militares. Por su parte, los conservadores se encontraron, por un periodo, satisfechos por las afinidades ideológicas con el régimen y la participación otorgada en los cargos públicos.

Por otro lado, tras las críticas de la prensa liberal a la influencia corruptora del conservatismo dentro del régimen y al cierre de El Tiempo por la denuncia del asesinato político de Emilio Correa Uribe y su hijo, los militares empezaron a contemplar la oportunidad de mantenerse por más tiempo a cargo del poder político al desplegar, desde finales de 1955, una estrategia para conseguir dicho objetivo. En principio, se lanzaron a partir de los medios oficiales a culpabilizar a los partidos como los únicos responsables del caos que vivió la República y a difundir una visión mesiánica de su función como salvadores de la patria. Luego, con el lanzamiento de la Tercera Fuerza y el apoyo de nuevos periódicos pro-militares como El Binomio de Calarcá en 1956, intentaron crear un movimiento político alternativo con antiguos miembros de los partidos tradicionales, los cuales ahora se declaraban leales a las Fuerzas Armadas y pedían el receso de los partidos, considerados la representación del odio y la retaliación. Estos hechos alarmaron a los liberales y a los laureanistas, quienes empezaron a tener acercamientos para restaurar la democracia, al gozar del eco que la prensa partidista empezó a darle a esta idea.

El punto final de la Dictadura estuvo dado por la pérdida de legitimidad de la ANAC, con el retiro progresivo del apoyo a esta por parte de Álzate Avendaño y Ospina Pérez, una vez que se hicieron públicas las aspiraciones de Rojas Pinilla por reelegirse en su cargo y por modificar la composición de la Asamblea a su favor. El papel de la prensa en esta etapa fue fundamental, pues desde sus páginas la imagen de Rojas Pinilla pasó de ser la del excelentísimo teniente, general y presidente de la República a la del dictador. En las columnas de los periódicos se desplegó una campaña por el retorno de la democracia, labor que solo les pertenecía a los partidos. De esta forma, con los partidos y el clero 
en su contra, Rojas renunció a su cargo el 10 de mayo y lo entregó a la Junta Militar. 



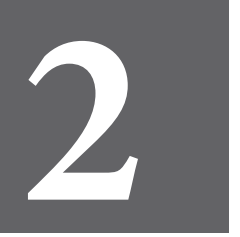

CAPÍTULO DOS 



\section{La pacificación entre la nación y la región: discursos y propaganda periodística del coronel Gustavo Sierra Ochoa, gobernador militar de Caldas (1953-1956)}

Jhon Jaime Correa Ramíre $z^{185^{*}}$

185* Doctor en Ciencias de la Educación de RUDECOLOMBIA, Magíster en Ciencia Política de la Universidad de Antioquia e Historiador de la Universidad Nacional de Colombia Sede Medellín. Profesor Titular de la Universidad Tecnológica de Pereira. Autor entre otros libros de: Civismo y educación en Pereira y Manizales (1925-1950) (2015) y Tinta Roja. Prensa política y educación en la República Liberal (1930-1946) (2016). 
FigURA NRO. 11. Portada de la revista Semana (1953).

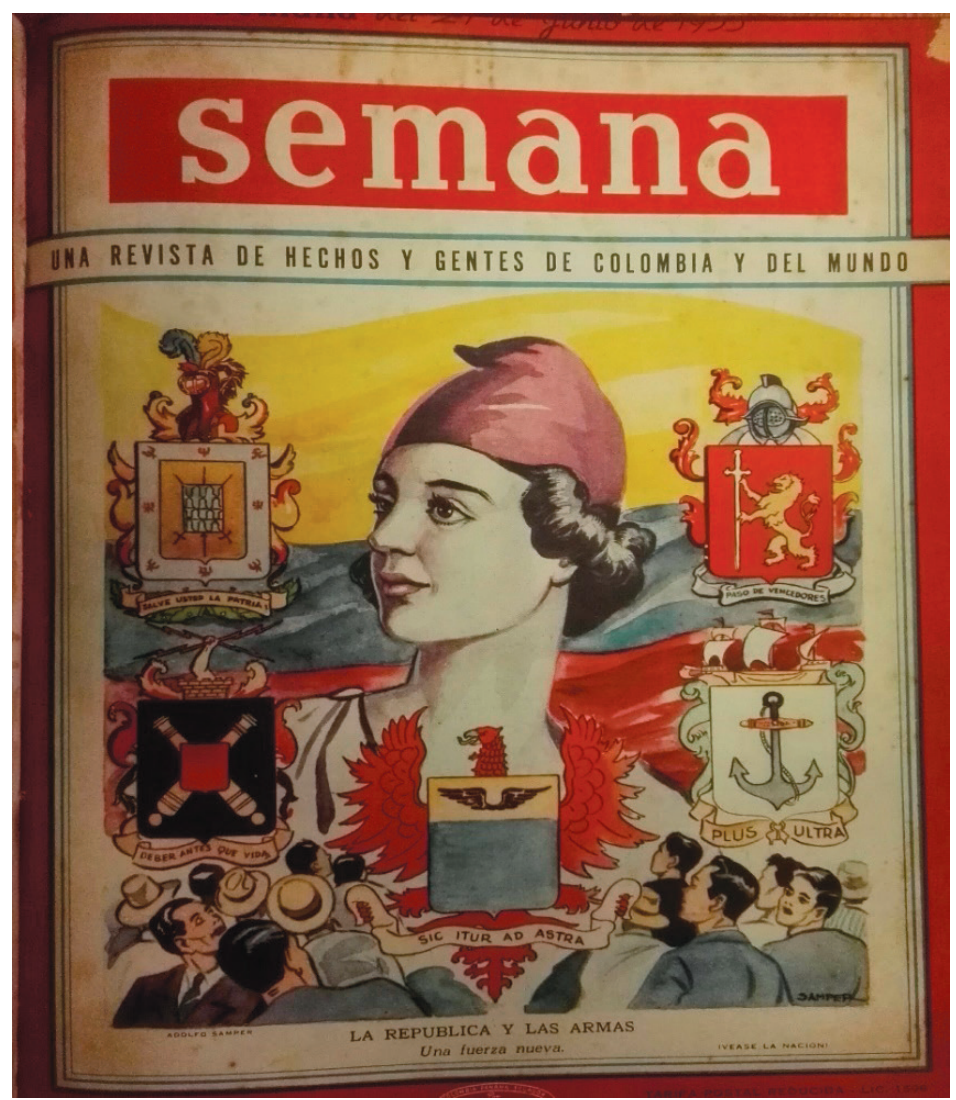

Fuente: Revista Semana [Bogotá], 27 de junio de 1953. La inscripción en latín sic itur ad astra traduce «hasta las estrellas».

El gobierno de las Fuerzas Armadas sólo [sic] desea paz y trabajo; anhela restañar las heridas abiertas por la ferocidad de los odios políticos, aliviar el destrozamiento producido en años anteriores por luchas insensatas que cercenaron las vidas honestas, agostaron la riqueza, y retrasaron el progreso, la cultura de nuestro pueblo por muchos años ${ }^{186}$.

186 Discurso pronunciado por el coronel Gustavo Sierra Ochoa, en Calarcá el 28 de marzo, con ocasión de su visita a la ilustre ciudad del Quindío. Gustavo Sierra Ochoa, Caldas trabaja. Por la patria, la paz y la justicia (Manizales: Imprenta Departamental, 1954), 108. 
En el presente capítulo se hace un seguimiento a los principales discursos realizados por el coronel Gustavo Sierra Ochoa $^{187}$-Gobernador de Caldas 1953-1956- en diferentes actos públicos y durante la entrega de algunas obras de infraestructura y acondicionamientos sociales en diversos municipios del departamento de Caldas, que fueron publicados por periódicos locales como El Binomio (Calarcá, Quindío), El Diario y otras publicaciones oficiales. Se trata de hacer énfasis en esa puesta en escena del poder gubernamental militar, la cual se pueden tomar como una forma de crear poder en el momento mismo de la enunciación, sobre todo, en la forma como cada discurso asumía tonos mesiánicos-salvadores o era un parteaguas entre un pasado reciente tormentoso y un presente futurista más diáfano. Como se podrá observar, mediante exaltados discursos nacionalistas, el gobernador Sierra Ochoa se articulaba con los postulados que desde el orden nacional promulgaba Rojas Pinilla, al reforzar un vínculo político y emocional entre el pueblo y las Fuerzas Armadas.

El 13 de junio de 1953 asumió la jefatura de la presidencia de la República de Colombia el teniente-general Gustavo Rojas Pinilla, mediante un golpe militar al Gobierno del presidente conservador Laureano Gómez, quien había asumido la presidencia en el año 1950 en uno de los momentos más tensos del periodo de La Violencia.

En uno de sus primeros discursos, el nuevo mandatario militar clamaba:

187 Gustavo Sierra Ochoa fue un militar reconocido por sus cualidades culturales y su afición por la buena música. Fue gobernador militar del departamento de Caldas durante los años 19531956 cuando fue trasladado a ejercer la Gobernación de Antioquia. Antes de este cargo público, participó como comandante del Batallón Páez de Sogamoso y fue uno de los encargados en la lucha contra las guerrillas del Llano, experiencia de la que publicó un libro en el año 1954 titulado: Las guerrillas de los Llanos Orientales. Sierra Ochoa murió en un trágico accidente aéreo "cuando se perfilaba como el posible sucesor de Rojas en el Palacio de San Carlos». Crónica del Quindío, «El último gobernador del Viejo Caldas», 10 de julio de 2016, https:// www.cronicadelquindio.com/noticias/region/el-ltimo-gobernador-del-viejo-caldas. 
No más derramamiento de sangre, no más depredaciones a nombre de ningún partido político. No más crímenes entre los hijos de una misma Colombia inmortal. Paz, Justicia, Libertad para todos sin discriminación, y con preferencia para las clases menos favorecidas por la fortuna. La patria no vivirá tranquila mientras sus hijos se hallen pobres y desnudos ${ }^{188}$.

Al igual que en muchos otros pasajes de la historia reciente de Colombia, la valoración y la comprensión histórica del Gobierno de Rojas Pinilla ha sido objeto de muchas controversias. Si bien desde algunas posturas historiográficas oficiales se tiende a ver como una anomalía o un paréntesis en el supuesto discurrir democrático y civilista de la política colombiana en el siglo xx; no cabe duda que en el momento de la posesión, su llegada al poder fue celebrada como un mecanismo de recomposición de la legitimidad del Estado para superar el sectarismo de los partidos políticos, y retomar la senda de la civilización y el progreso que tanto preocupaba a las elites y a los gremios económicos del país ${ }^{189}$.

Una de sus tareas principales, en el momento de asumir el poder, fue tratar de amainar el clima de intemperancia política vivido en muchas regiones del país. En particular, Rojas buscaba conceder una amnistía a los miembros de las guerrillas liberales y desarrollar ambiciosos programas de intervención cívico-militar a cargo de las Fuerzas Armadas para la reconstrucción económica de las zonas afectadas por la violencia bipartidista. Otra de las labores inaplazables para el nuevo régimen era superar la censura de prensa practicada desde años atrás, asunto bastante polémico y que fue objeto de un constante «tira y afloje» entre el Gobierno y algunos medios de comunicación del país ${ }^{190}$.

188 Eduardo Pizarro León Gómez. «La profesionalización militar en Colombia (III): los regímenes militares (1953-1958)», Análisis Político, n. ${ }^{\circ} 3$ (1988): 4.

189 Ronal Fabián Rodríguez Durán, Rojas Pinilla ¿un dictador? De la dictadura positiva a la dictadura negativa (Bogotá: Universidad del Rosario, 2006).

190 Olga Yanet Acuña, «Censura de prensa en Colombia, 1949-1957», Historia Caribe 8, n. ${ }^{\circ} 23$ (2013): 243. 
Para llevar a cabo esta misión, Rojas Pinilla nombró al coronel Gustavo Sierra Ochoa como gobernador del departamento de Caldas, una de las zonas más afectadas por La Violencia en el centro occidente colombiano. Según los estudios de Guzmán, Fals y Umaña, esta jurisdicción era una de las zonas con mayor concentración de grupos armados. Además de ocupar por varios años el primer lugar en cuanto a número de homicidios, amenazas y migración forzada campo-ciudad entre 1946 y $1953^{191}$, los hechos de violencia eran el pan de cada día en las distintas subregiones; al tiempo que se desarrollaban fogosas campañas políticas: Oriente (Marquetalia, Victoria, Samaná, entre otros) ${ }^{192}$, Occidente (Quinchía, Guática, Anserma, Belén de Umbría, Belalcázar, entre otros), pero sobre todo, en la región del actual departamento del Quindío, zona limítrofe con el territorio del Tolima y el norte del Valle del Cauca por donde avanzaban cuadrillas de grupos armados ilegales y bandoleros. De la misma manera, los principales centros urbanos de este, Manizales - como capital departamental-, Pereira y Armenia fueron receptores de una gran cantidad de migrantes ${ }^{193}$.

\subsection{El poder militar como senda para retomar el camino de la convivencia y la paz}

Con un abnegado sentido del deber, Sierra Ochoa, quien recién llegaba de enfrentar las guerrillas de los Llanos Orientales colombianos, se posesionó el 24 de septiembre de $1953^{194}$ en la ciudad de Manizales y reemplazó al gobernador Fernando

191 Guzmán, Fals y Umaña, La Violencia ..., 115.

192 Ramírez y Jiménez. Marquetalia, La Violencia..., 66.

193 Jhon Jaime Correa Ramírez, «La otra Pereira. Migraciones, desborde popular, historia barrial e inclusión». En De la aldea a la ciudad. Personajes y hechos que forjaron a Pereira, ed. por El Diario (Pereira: El Diario, 2019), 103.

194 Orlando Cadavid Correa, «Los nueve gobernadores militares de Caldas», EJE 21, 13 de marzo de 2016, https://www.eje21.com.co/2016/03/los-nueve-gobernadores-militares-de-caldas/. 
Londoño y Londoño ${ }^{195}$. Tras pasar por una calle de honor y recibir los honores de una banda de guerra, llegó al palacio de la gobernación y desde allí dirigió su primer discurso ante una concurrida audiencia ${ }^{196}$.

Figura NRo. 12. Coronel Sierra Ochoa y Lucio Pabón Núñez

Ministro de Gobierno de Rojas Pinilla, acompañados de sus respectivas esposas.

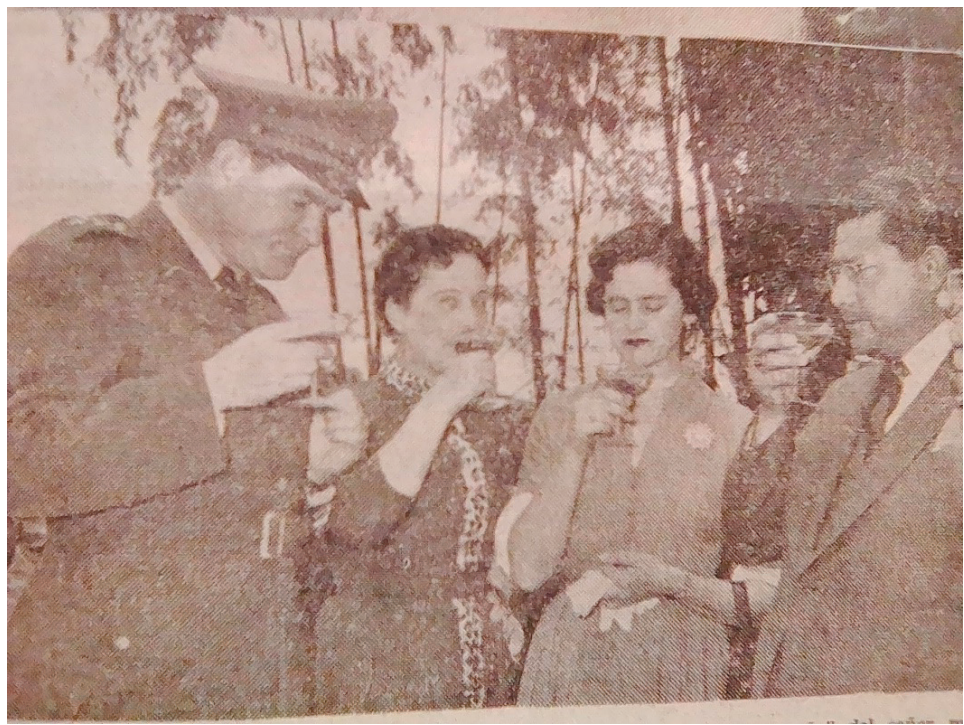

Fuente: La Patria [Manizales], 24 de agosto de 1954.

Desde aquel momento quedó muy clara la consigna de la misión que asumiría Sierra Ochoa en esta zona del país. Al tomar como referentes los lemas nacionales del Gobierno de

195 El Diario [Pereira], 24 de julio de 1953: 1. Londoño Londoño era un destacado dirigente conservador de la ciudad de Manizales. Había sido nombrado por Rojas Pinilla como gobernador de Caldas el 24 de junio de 1953, es decir, a pocos días del golpe contra Laureano Gómez. Sin embargo, duro pocos meses en el cargo, debido a las suspicacias y malestares que su nombre generaba entre los dirigentes liberales de varias secciones del departamento. Además, en una columna de primera plana de El Diario — de la ciudad de Pereira-, del lunes 24 de julio de 1953, se informaba que los exilados del occidente del departamento de Caldas, radicados en Pereira, iban a solicitar una audiencia con el general Rojas Pinilla en su próxima visita a la ciudad, para quejarse de la falta de garantías por parte del gobernador Londoño Londoño de cara a poder regresar a sus parcelas.

196 El Diario [Pereira], 24 de septiembre de 1953: 1. 
Rojas Pinilla — «Paz, Justicia y Libertad»—, se puede hacer una síntesis de los aspectos en los que más hizo énfasis durante su gestión al mando de los asuntos políticos-administrativos y de orden público de la región. La definición de un plan de acción y la elección de un gabinete idóneo de secretarios de despacho, el cual ayudaría a apaciguar los ánimos sectarios de las colectividades políticas en las diferentes municipalidades del departamento «modelo de Colombia», eran las tareas que mantenían en vilo a la opinión pública que se informaba a través de periódicos como La Patria de Manizales y El Diario de Pereira. Otro campo, el cual demandaba la atención del nuevo gobernante, tenía que ver con la educación y la formación técnica de la juventud y, sobre todo, con la búsqueda de una mayor cordura política en las rivalidades de las colectividades partidistas.

El coronel Sierra Ochoa tampoco escatimó el más mínimo esfuerzo en la creación y sostenimiento de un periódico que sirviera como medio de información sobre la gestión de su gobierno y que, a la par, cumpliera con el propósito educativo de arraigar el vínculo político y emocional entre el pueblo cafetero caldense y las Fuerzas Armadas. El Binomio se empezó a editar semanalmente en el municipio de Calarcá, desde el 30 de junio de 1956 bajo la dirección de Luis Alfonso Peña G. ${ }^{197}$. El «binomio nacional» era el rótulo con el cual se autoproclamaban las Fuerzas Armadas como la tercera fuerza política del país, al hacer alusión a sus altos y patrióticos intereses suprapartidistas encarnados en la figura carismática del general Rojas Pinilla, y del grupo de leales gobernadores y alcaldes militares nombrados en los diferentes departamentos. En este periódico se publicaban las principales acciones cívico-militares de las autoridades castrenses al mando de los asuntos públicos del departamento y, además, se resaltaba en pequeños recuadros - a modo de epígrafes o propaganda publicitaria- algunas frases que daban cuenta del anhelo de paz y concordia, el cual movía al gobernador Sierra Ochoa, pues decía: «Demos tregua a los rencores, pausa a la cólera, término a la

197 El Binomio [Calarcá], 30 de junio de 1956: 1. 
matanza, cesación de esa batalla que no tiene banderas ni clarines, himnos ni canciones» ${ }^{198}$.

FigURA NRo. 13. Manizales recibe al general Rojas Pinilla.

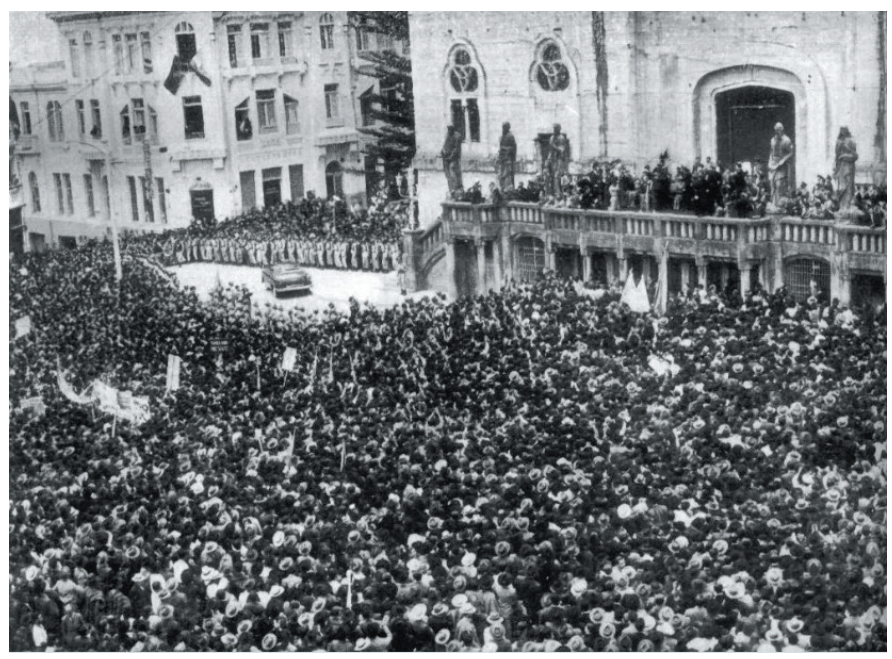

Fuente: «El libro total», https://www.ellibrototal.com/ ltotal $/ ? \mathrm{t}=1 \& \mathrm{~d}=4669$.

Como era de suponerse, los representantes del Gobierno militar a nivel regional debían promover de manera constante los lemas de «Paz, Justicia y Libertad». A la par, Sierra Ochoa mantenía su fiel adhesión a tres elementos claves del orden político y social nacional como la bandera: la Iglesia católica y la Constitución. Se podría decir que, ante todo, se trataba de ganar la simpatía y la adhesión de las diversas capas sociales de las regiones mediante un discurso vitalista de una fe religiosa renovada; no de manera sectaria como la promovieron algunos sectores católicos conservadores. En su lugar la nueva consigna de concordia era superar las «barricadas de odio» y las «... bárbaras enemistades suscitadas entre padres e hijos, entre hijos y hermanos, entre colonos y camaradas de la misma estirpe» ${ }^{199}$.

198 El Binomio [Calarcá], 8 de julio de 1956: 1.

199 Sierra Ochoa, Caldas trabaja..., 14. 
Los periódicos regionales registraron, con un particular interés, los puntos centrales del programa del nuevo gobernante. En El Diario de Pereira se informó, durante varias entregas, acerca del ambicioso programa económico propuesto por el militar de carrera, el cual contemplaba aspectos diversos como la tecnificación de la agricultura, el fomento de la pequeña y la gran industria, la construcción de vivienda, el ensanchamiento y pavimentación de carreteras, la explotación de recursos naturales como el carbón, las industrias cementeras, la electrificación de campos y ciudades, además de «... todo aquello que convenga al capital y al trabajo» ${ }^{200}$. Igualmente, eran constantes los llamados a las autoridades locales para el manejo pulcro del erario y, al mismo tiempo, se convocaba a las entidades cívicas de todo el departamento para contribuir a mejorar la educación moral y técnica de la población, como el medio más expedito y eficaz para estar a la altura de la nueva ruta civilizatoria que querían trazar las Fuerzas Armadas en el país.

Era evidente que la locuacidad del coronel Sierra se daba a la par de una intensa actividad publicitaria para difundir los actos de Gobierno, uno de cuyos ejes era el cuestionamiento sistemático de los odios banderizos de los partidos tradicionales. Del mismo modo, compartía la idea - la cual volvió a cobrar vigencia en aquellos años - de cierto sustrato de barbarie o atavismos en el pueblo colombiano, que había obligado a vivir «...como chacales hambrientos de la reputación de nuestros hermanos, impulsados por inconcebible sevicia de un corrosivo olor ${ }^{201}$. En tal sentido, se justificaba el papel mesiánico de las Fuerzas Armadas como una $« \ldots$ reserva sana de la nacionalidad ${ }^{202}$.

Al cumplir el primer mes de gobierno, Sierra Ochoa mostraba con orgullo que había empezado por organizar la casa, es decir, la estructura y las finanzas del ente departamental tanto en términos de superar los sesgos partidistas como en el manejo de la

200 El Diario [Pereira]. 27 de septiembre de 1956: 4, 8.

201 Sierra Ochoa, Caldas trabaja ..., 15.

202 Sierra Ochoa, Caldas trabaja ..., 15. 
situación fiscal. Todo esto bajo un riguroso sistema de planeación y estadísticas departamentales, las cuales también llevaron a cambios significativos en la organización de la Contraloría Departamental al nombrar al mayor Gerardo Delgado Nieto para reorganizar dicho ente de control ${ }^{203}$. Durante su mandato se creó la Cooperativa de Municipalidades con el fin de atender, de manera planificada, el desarrollo de sus principales obras de servicios públicos. Asimismo, llevó a cabo una importante reforma en la estructura administrativa de la Industria Licorera de Caldas al separar sus funciones de la Administración de Rentas Departamentales ${ }^{204}$.

En las conclusiones de este pronunciamiento proferido tras el primer de gestión al frente la administración departamental, el gobernadordestacabala necesidadde «... sustraerlaadministración pública de la nefanda influencia politiquera». Señalaba, a renglón seguido, la importancia de imprimirle la disciplina y la organización del estamento castrense a la administración pública «... con ascensos, jubilaciones, retiros, sanciones con el más estricto sentido de rendimiento y de justicia» ${ }^{205}$. Consideraba que el servicio público no podía «... seguir siendo botín de las intrigas disolventes y de las interferencias de viejos caciques exclusivistas» ${ }^{206}$.

Al ser muy consciente de las rivalidades políticas en diferentes municipios y de los recelos que muchos poblados del departamento tenían respecto a la capital, Manizales, Sierra Ochoa realizó constantes visitas de inspección a todas las regiones

203 Sierra Ochoa, Caldas trabaja..., 77.

204 Sierra Ochoa, Caldas trabaja..., 33.

205 Sierra Ochoa, Caldas trabaja..., 39.

206 Sierra Ochoa, Caldas trabaja..., 33. Un detalle sobre el que vale la pena hacer hincapié es el llamado que se hacía a los militares desde algunas columnas de prensa para que resolvieran no solo problemas de cuadrillas de bandoleros en el campo, sino también para que pusieran mano dura en las ciudades, como una forma de mantener a raya el desaseo, la delincuencia creciente, la vagancia y las ventas ambulantes. En este se decía: «Que vengan los militares para que la administración pública se sature de sólido elemento en la parte constructiva de la justicia y la equidad [...] Sólo [sic] el militar que tiene una educación de carácter férreo en el cumplimiento de sus obligaciones y deberes puede devolverle al pueblo su moral y su perdida libertad». Labor militar. El Diario [Pereira], 25 de noviembre de 1953: 8. 
del departamento con el propósito de evitar «... las complacencias discriminatorias que rompen la unidad departamental y perjudican notoriamente el progreso uniforme de esta sección ${ }^{207}$.

A la par de esta serie de noticias y comunicados, es muy llamativo palpar el ambiente político de aquel momento, en especial cuando se observa en la prensa - consultada de la épocay en los discursos de Sierra Ochoa - publicados durante tres años consecutivos por la Imprenta Departamental de Caldas-, el despliegue de un amplio repertorio discursivo con el cual se pretendía hacer calar, en las diferentes capas de la sociedad, la labor restaurativa y «sanadora» de las Fuerzas Armadas. De manera especial, se empezó a tomar la fecha del 13 de junio como un hito fundacional de la rehabilitación moral y política de la nación colombiana. Calles, parques, avenidas, escuelas, puentes y centros de salud empezaron a ser bautizados con este nombre, como dispositivos públicos de una labor pedagógica y simbólica con la que el Gobierno del general Rojas Pinilla quería marcar el presente y el futuro histórico por construir de la nación. En efecto, el 13 de junio se mostraba ante la opinión pública no como un simple relevo de mando, sino como una revolución moral, la cual devolvería el país a su alterada fisionomía.

En estos primeros meses, el Gobierno militar de facto mantenía algo así como una luna de miel con los distintos sectores de la sociedad y la opinión pública. Por ejemplo, El Diario de la ciudad de Pereira reprodujo el 25 de septiembre de 1953, la columna de «La Danza de las Horas», del reconocido periodista liberal de El Tiempo, Calibán. En ella se reconocía que tras apenas cien días de gobierno - momentos fecundos de prosperidad y bienestar-, Rojas Pinilla había logrado recuperar el orden público, la normalidad y la legalidad. Con lo cual aprovechó para señalar que en su gobierno solo quedaba «una sombra»: «la injustificable censura de prensa [...] ¿Por qué no eliminarlo? ¿Por qué seguir dando esa falsa impresión de que un régimen popular necesita de recursos como este de la censura de prensa? ${ }^{208}$.

207 Sierra Ochoa, Caldas trabaja ..., 75.

208 El Diario [Pereira], 25 de septiembre de 1953: 4. 
Al parecer, esta columna motivó a que los directores de diferentes periódicos liberales y conservadores le enviaran al presidente de la República sendas en las cuales le solicitaban el levantamiento de la censura en contra del periódico El Siglo, de propiedad de Laureano Gómez. En efecto, el 30 de septiembre de ese mismo año, El Diario publicó en primera plana la noticia que tanto se esperaba. En la comunicación se señala lo siguiente:

El director de Información y Propaganda del Estado, en uso de sus facultades legales y especiales [...] y considerando:

Que distinguidas personalidades se han dirigido al excelentísimo señor Presidente [sic] de la República, solicitándole la reconsideración de la sanción ordenada a El Siglo de Bogotá. Que a dicho periódico se le sancionó por resolución número 0057 de fecha 24 de los corrientes, en vista de que violó la censura de prensa con la publicación de un manifiesto subversivo contra la orden expresa y reiterada de la censura y no obstante ello el gobierno para dar una nueva demostración de que sólo [sic] lo guía el propósito de robustecer el clima de la convivencia nacional, accede a la solicitud que se le ha formulado en esperanza de que esa actitud será correspondida por el periódico El Siglo, absteniéndose de publicar todo aquello que pueda alterar la paz pública o dificultar la obra del gobierno en pro de la reconstrucción nacional.

En consecuencia, resuelve:

Artículo único: A partir de la fecha suspéndese la sanción impuesta a El Siglo de Bogotá y autorizase su libre circulación en todo el territorio nacional ${ }^{209}$.

Este tema de la libertad de prensa constituía un asunto público que movía profundas fibras políticas y emocionales tanto en el gobierno militar como en la prensa hablada y escrita de todo el país. Al cabo de un tiempo, entre los años 1955 y 1957, el tema de la censura a los medios de comunicación fue uno de los 
factores que ayudó a desencadenar un recelo profundo entre los principales medios difusivos de todo el país hacia el régimen de Rojas Pinilla y su posterior caída ${ }^{210}$.

No obstante, como se señaló anteriormente, durante el primer año de Rojas en el poder, la prensa nacional y regional logró superar una serie de mutuos recelos y recriminaciones las cuales se hacían entre los directores y jefes de partido, para ponerse a marchar al lado de las filas del gobierno militar. El primer mandatario había logrado inculcar la idea de que la opinión pública no era la que, quizás de manera amañada, podían crear algunos periodistas para defender intereses personales, fueran estos económicos o políticos. Según su criterio, «... la verdadera opinión pública es la que el primer mandatario ve y palpa cuando llega a las calles y plazas de las poblaciones a oír la voz del pueblo» ${ }^{211}$. A tal punto llegaba el entusiasmo con la figura de Rojas Pinilla que, en una columna de El Diario, fechada a finales de noviembre de 1953, se empezaba a mencionar el ambicioso plan de rehabilitación con el cual se atendería a los «exiliados» por la violencia en los campos de Colombia, no dudaban en llamarlo - en un tono bastante mesiánico- el «segundo Libertador de Colombia», quien había reintegrado el país «... a su estado de sosiego, de paz y tranquilidad, de que había disfrutado por muchos años, a contar desde 1910 hasta $1948 »^{212}$.

Tal vez motivados por este buen ambiente político, uno de los editores de El Diario, J. T. H., se atrevió a solicitar al «excelentísimo

210 Álvaro Tirado Mejía, «Rojas Pinilla: de golpe de opinión a exilio», En La Nueva Historia de Colombia (Tomo II: Historia política 1946-1986), ed. por Álvaro Tirado Mejía (Bogotá: Editorial Planeta), 112.

211 Declaraciones de Rojas Pinilla, Revista Sábado 10 (1953): 7-8.

$212 \mathrm{Al}$ año siguiente, se creó en Pereira la Oficina de Rehabilitación y Socorro. El Diario [Pereira], 26 de noviembre de 1953: 8. Según esa misma información, se calculaba que en ese momento había en Pereira una población cercana a los 2500 «exiliados» provenientes de los municipios del occidente caldense como Santuario, La Celia, Belén de Umbría, Apía, Belalcázar, Mistrató, Viterbo, Anserma, Guática, San Clemente y Pueblo Rico; así como de otras poblaciones del Norte del Valle del Cauca como Ulloa y Alcalá; además de varias poblaciones del Quindío «tales como Génova, Pijao, Montenegro, Salento, etc. [sic]». 
presidente», como aguinaldo para los colombianos, que levantará el estado de sitio que aún prevalecía en el país. Por tanto, dijo lo siguiente:

Ahora cuando ya este año de 1953 toca a su fin y todos sentimos el deseo de exteriorizar la felicidad que traen consigo las fiestas navideñas, y anhelamos comenzar el año nuevo con horizontes más halagadores que los que vislumbramos al comenzar el año presente, se nos ocurre que el General Presidente [sic] podría darnos a todos los colombianos el mejor y más preciado de todos los regalos, levantando el estado de sitio en que ya casi creemos que se tiene al país injustamente ${ }^{213}$.

En su deseo de devolverle la paz a las diferentes regiones del país y el goce pleno de los derechos a la ciudadanía, el tema del estado de sitio seguía siendo un tema inobjetable para las Fuerzas Armadas a pesar de promover a los cuatro vientos una acción cívico-militar que autoproclamaban como una verdadera tercera fuerza política nacional. Frente a la idea promovida por los militares acerca de «la fuerza de las armas al servicio del pueblo», era evidente el deseo que tenían las fuerzas castrenses por imponer sus dictados a toda la población colombiana como único medio para superar los «odios insanos de secta» del pasado reciente.

No se entiende de otra manera el discurso que Sierra Ochoa ofreció en Armenia el 27 de marzo de 1954, en el cual señalaba que el único camino que quedaba para restablecer el orden era la «adaptación política o violencia». Al hacer uso de una particular metáfora, el gobernador militar de Caldas planteaba que lo correspondiente era «Adaptarnos al vaso de la autoridad, ajustarnos a las modalidades del mando sin manifestaciones de violencia, sin tratar de destruir el recipiente... ${ }^{214}$.

213 El Diario [Pereira], 16 de diciembre de 1953: 4.

214 Sierra Ochoa, Caldas trabaja..., 95. 
Lo anterior era otra forma de justificar que se mantuviera el estado de sitio en el país. Sierra Ochoa hacía una constante alusión en sus declaraciones públicas sobre una serie de organizaciones las cuales actuaban al margen de la ley y fomentaban en algunas veredas de Caldas «nuevos odios, [y] nuevas pasiones violentas, con objetivos que apenas [...] [podían] disfrazar tenuemente». Con ello se refería a las alineaciones comunistas, las cuales engañaban y sobornaban al pueblo a través de «satánicos planes de acción con calculada maña y [...] [abrían] las puertas del caos $\mathrm{y}$ del desconcierto social en donde menos se [pensaba]...» ${ }^{215}$.

Lo más llamativo de esta denuncia era que el coronel Sierra Ochoa relacionaba los «oscuros» propósitos de las «prácticas infernales» del comunismo con la desmembración del departamento - tema del que ya se hablaba con cierta frecuencia en estos años-. En realidad, lo que se logra observar es que el Ejército se valía de un discurso en el cual hacían referencia a la población campesina como si aún no ejercieran su mayoría de edad. Tanto por engaño, como por los odios viscerales casi «salvajes» o por su incapacidad para comprender los riesgos de ideologías foráneas como el comunismo. En un discurso pronunciado por Sierra Ochoa en la ciudad de Armenia, el 27 de marzo de 1954, él señalaba: «No os dejéis engañar por las patrañas miserables que se os espetan. Vosotros sois fuertes, pero muchas veces demasiado ingenuos ante el enemigo diestro y avezado que os ataca desde la sombra $»^{216}$.

215 Sierra Ochoa, Caldas trabaja..., 96. Llama la atención en esta declaración del coronel Sierra Ochoa, que pretendía simplificar los hechos de violencia en la región, achacándoles su origen y motivación a la penetración del comunismo entre el campesinado de la región — como quizás sí sucedía en otras regiones del Tolima y Cundinamarca - o que desconocía profundamente las motivaciones políticas —nexos entre cuadrillas liberales con políticos o caciques de las localidades - , sociales e incluso psicológicas — entre odios, adhesiones y temores - de muchos hechos de sangre, de venganzas personales y de retaliaciones políticas que, rápidamente, dieron lugar a la creación de cuadrillas armadas de pájaros, chusma o de «cachiporros». Al respecto ver: Ortiz, Estado y subversión..., 224-262.

216 Sierra Ochoa, Caldas trabaja..., 97. 
Este era el llamado generalizado hecho a la ciudadanía de Caldas para que despertará del letargo político en el cual permanecía sumida. La proclama buscaba que todas las personas acompañaran a las autoridades de las FF. AA. en su labor de extirpar las "células cancerosas», las cuales amenazaban con invadir el organismo sano y de buenas costumbres cristianas de los campesinos que habitaban en las montañas cafeteras de esta región del país. En ella se decía:

No olvidéis que las células enfermas, si se les deja actuar dominan a las sanas, y el cáncer se va extendiendo por todo el organismo. Eso ocurre en el cuerpo humano y también en las masas, en las multitudes, en las colectividades. Cuando la infección no se ataja; cuando a los cancerosos los aceptamos; cuando permitimos a los enfermos estar con nosotros, aún en minoría, éstos nos colocan en permanente situación de peligro ${ }^{217}$.

De esta manera, el Ejército realizaba una intensa labor publicitaria de sus gestiones y de su ideología orgánica, la cual proclamaba el vínculo indisoluble entre las FF. AA. y el pueblo por encima de los partidos tradicionales, a quienes no se cansaba de acusar por sembrar el sectarismo y por carecer de una organización política más responsable que los alejara de su fratricida "carrera de relevos» por alcanzar el poder. En lugar de esto, los militares colombianos proclamándose como una fuerza política suprapartidista, nacionalista, popular, modernizadora, católica y anticomunista, planteaban una serie de ideales -ideas fijas, decían - que estaban en consonancia con los gobiernos populistas liderados por militares en otros países de América Latina como era el caso de Argentina, Brasil, Perú y Guatemala ${ }^{218}$.

Así lo denunciaba Sierra Ochoa de manera enfática, el 28 de marzo de 1954, en la población de Calarcá, al expresar un profundo espíritu de cuerpo en las Fuerzas Armadas colombianas bajo el liderazgo de Rojas Pinilla:

217 Sierra Ochoa, Caldas trabaja..., 97.

218 Renzo Ramírez Bacca, Apuntes sobre historia socio-política y económica de América Latina en el siglo XX (Pereira: Editorial Universidad Tecnológica de Pereira, 2020). 
Las Fuerzas Armadas no han llegado al poder inspiradas en este manido proceso, atadas a esta conceptiva forma de turno; ellas no están participando en ningún caso en el poder como una nueva clientela partidista, sobre los viejos moldes una política de campanario. El país debe entender que las Fuerzas Armadas han llegado a la primera magistratura, no para cumplir un ciclo político más en el relevo de rigor [...] El ejército, a diferencia de los partidos políticos, se mantiene a una prudente línea de respeto de los valores consagrados en el espíritu permanente de la nacionalidad. Por eso, la política del ejército indefectiblemente tiene que ser la política del Estado ${ }^{219}$.

Esta serie de discursos dejan ver una reiterada justificación y autolegitimación de las FF. AA. para proseguir en el poder por tiempo indefinido al mando del Estado colombiano. Las referencias ideológicas tanto de Rojas Pinilla como de Sierra Ochoa evadían los senderos formales de la Constitución y el respeto de los derechos liberales consagrados en ella. Es decir, los fundamentos políticos promovidos por los militares al poder del Estado estaban fuertemente anclados en nociones más tradicionales de la nación, a saber, el catolicismo, los valores morales conservadores, el orden público, entre otros y, demás, adjetivos espumosos propios de las convicciones del buen patriota soldado. Sin embargo, no hacían una clara referencia a principios claves y modernos de la organización estatal tales como la democracia, la constitución y la división de poderes. Quizás por ello, poco a poco, se iría acabando la luna de miel con algunos sectores de la vida pública nacional, tal como sucedió con los estudiantes universitarios; aquellos que fueron masacrados por tropas oficiales en Bogotá el 9 de junio de 1954, descontento que le abrió paso a la radicalización del descontento de los movimientos estudiantiles. ${ }^{220}$.

219 Sierra Ochoa, Caldas trabaja..., 104.

220 Absalón Jiménez, «Una mirada al movimiento estudiantil colombiano. 1954-1978», Boletín Cultural y Bibliográfico 51, n. ${ }^{\circ} 93$ (2017): 8. Ver también: Ciro Quiroz Otero, La Universidad Nacional en sus pasillos, y fuera de ellos. 2. ${ }^{\mathrm{a}}$ edición (Bogotá: Universidad Nacional de Colombia, 2018), 108-109; Pedro Luis Belmonte, Antecedentes históricos de los sucesos del 8 y 9 de junio de 1954 (Bogotá: Imprenta Nacional, 1954); Carlos Medina Gallego, 8 y 9 de junio, «Día del estudiante»: crónicas de violencia, 1929 y 1954 (Bogotá: Ediciones Alguimia, 2004); José Abelardo Díaz Jaramillo, «El 8 y 9 de junio y las disputas por la memoria 1929-1954», Historia y Sociedad, n. ${ }^{\circ} 22$ (2012): 157-189; Miguel Ángel Beltrán, «La Federación de Estudiantes Colombianos (FEC) y las luchas universitarias bajo la dictadura del general Gustavo Rojas Pinilla», Cardinallis, n. ${ }^{\circ}$ 10 (2018): 16-40; Manuel Ruiz Montealegre, Sueños y realidades: Procesos de organización estudiantil 1954-1966 (Bogotá: Universidad Nacional de Colombia, 2002). 
Figura NRO. 14. «Sucesos de ayer en Bogotá».

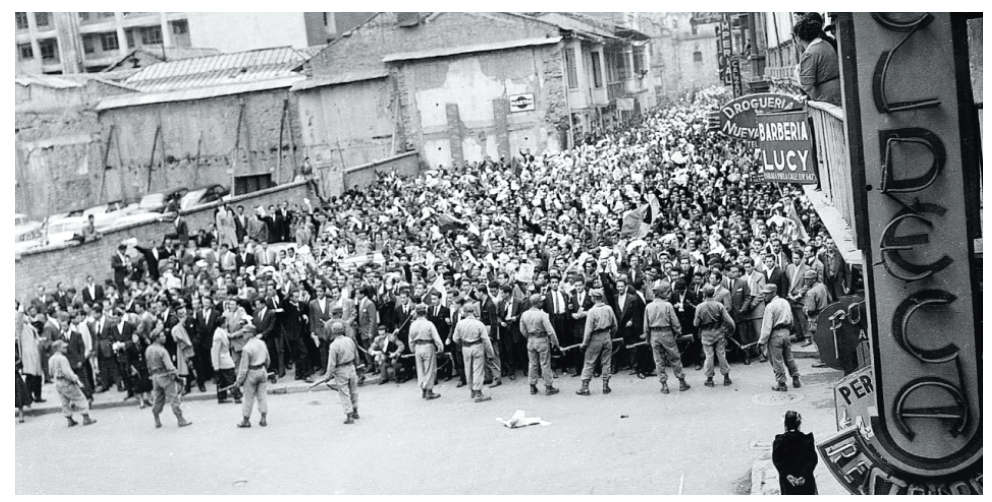

Fuente: El Tiempo [Bogotá], 10 de junio de 1954.

La marcha se encontró con los soldados del Batallón Colombia en la calle 13 con $7 .^{\text {a }}$, hacia las 11 de la mañana.

Otras actuaciones de Rojas empezaron a preocupar a los dirigentes políticos y gremiales del país. A finales del año 1953, dicho personaje había contribuido decididamente a la conformación de la Confederación Nacional del Trabajo (CNT) como una gran asociación sindical que hacía contrapeso a la Confederación de Trabajadores de Colombia (CTC) — de origen liberal, creada durante el Gobierno de López Pumarejo - y a la Unión de Trabajadores de Colombia (UTC) — de origen conservador y sobre la cual la jerarquía eclesiástica ejercía un enorme poder-. Además, siguiendo los pasos de su homólogo militar argentino, el líder populista Juan Domingo Perón, conformó un nuevo movimiento político, el Movimiento de Acción Nacional (MAN), en el que participaban algunos políticos de los dos partidos tradicionales e incluso un grupo de socialistas. Tanto desde la CNT como desde el MAN se realizaban marchas de apoyo al general Rojas y demás gobernantes militares en el resto del país, con arengas que revivían las proclamas gaitanistas contras las oligarquías, lo cual no dejaba de preocupar a los sectores de la elite del país ${ }^{221}$.

221 Tirado Mejía, «Rojas Pinilla: de golpe de opinión a exilio»..., 112. 
Tras el leve respiro de la censura de prensa a finales del año 1953, a partir del 6 de marzo de 1954, se reactivó esta orden sobre los medios de comunicación de todo el país. Posteriormente, el 7 de agosto de 1954, la Asamblea Nacional Constituyente, que había sido remozada con simpatizantes del Gobierno militar, reeligió a Rojas para ejercer el poder en la Presidencia de la República, al ratificar la necesidad de fijar límites muy precisos para los partidos, la prensa y la ciudadanía en general ${ }^{222}$. Con el correr de los días, las críticas hacia el régimen se incrementarían. Tras los resultados electorales de la ANAC, en el seno del Partido Liberal empezaron a surgir ciertas sospechas sobre la manera como Rojas Pinilla manejaba la composición de la misma para satisfacer, en la mayoría de los casos, los caprichos del Partido Conservador ${ }^{223}$.

Otras importantes iniciativas del Gobierno empezaron a ser objeto de reiteradas críticas como en el caso de la Secretaría Nacional de Asistencia Social (SENDAS) —-dirigida por la hija del general, María Eugenia Rojas Pinilla-, el Instituto Nacional de Abastecimiento (INA), El Diario Oficial - que fue la propia tribuna rojaspinillista por un buen tiempo, muy criticado por El Tiempo y El Espectador-, e incluso, la construcción del aeropuerto El Dorado y la Televisora Nacional, sobre los cuales recaía un manto de sospecha por los altos costos en los que incurría Rojas Pinilla para su propaganda oficial y por el manejo personalista que se le dio a estas entidades, a través de las cuales se hacía un constante despliegue publicitario sobre las ejecuciones de este polémico personaje de la historia reciente de Colombia, quien prontamente dejó de ser considerado redentor nacional para convertirse en dictador ${ }^{224}$.

A pesar de estas críticas, la idea de sostener el binomio Ejército-pueblo seguía el rumbo político que el general Rojas había trazado desde un comienzo. En las regiones, el proyecto cobraba sentido mediante las ejecutorias de los respectivos gobernadores. Juan David Robledo, secretario de Gobierno de Sierra Ochoa

222 Tirado Mejía, «Rojas Pinilla: de golpe de opinión a exilio»..., 115.

223 El Diario [Pereira], 15 de septiembre de 1954: 4.

224 Tirado Mejía, «Rojas Pinilla: de golpe de opinión a exilio»..., 121. 
en el departamento de Caldas, en una alocución radial del año 1954, defendía la labor llevada a cabo durante el primer año de gestiones. Del mismo modo, validaba la idea de llevar a cabo una gestión con un gobierno fuerte y sin privilegios al decir:

El ejecutivo departamental es alérgico a los favoritismos, a los grupos privilegiados [...] Mientras el coronel Sierra Ochoa y yo estemos en el gobierno de Caldas no habrá ni "contemplados" ni "caciques" $[\ldots]$ Gobierno fuerte sí, pero para todos, para imponer el imperio del orden, para prevenir los desbordamientos anárquicos, para asegurar el libre ejercicio de los derechos a la universalidad de los ciudadanos, para realizar una justicia social a tono con los tiempos y con la realidad nacional ${ }^{225}$.

La dinámica política de aquellos años se debe analizar con suma atención ya que si bien se advertían unos primeros síntomas de recelo frente al posible autoritarismo del presidente Rojas Pinilla, era evidente que, aún a mediados del mes de septiembre de 1954, su Gobierno contaba con el respeto y la confianza de una buena parte de los medios de comunicación, los gremios, los partidos políticos y la ciudadanía. En un editorial del 13 de septiembre de 1954, que los propietarios de El Diario reprodujeron del periódico capitalino El Tiempo, se reconoce el buen papel político desempeñado por los gobernadores militares en las diferentes regiones del país consideradas como violentas. En este se decía: «Se puede confiar en su ecuanimidad, en su decisión de servicio, en su alejamiento de la beligerancia partidista». Pero, a renglón seguido, se hacía un llamado a trabajar con «cierto discreto orden, dejando de lado lo espectacular, lo superfluo, lo que pudiera resultar excesivamente gravoso e inútil» ${ }^{226}$. Todo ello en una clara alusión al despilfarro del erario en manos de Rojas Pinilla.

225 Sierra Ochoa, Caldas trabaja..., 104.

226 El Diario [Pereira], 13 de septiembre de 1954: 4. 
De esta manera avanzaba la gestión del gobernador militar Sierra Ochoa en Caldas, una región donde a pesar de los esfuerzos del Ejército por asegurar la paz y «la concordia» — como se decía en aquellos días - entre los partidos políticos, eran numerosos los homicidios, los heridos por arma de fuego y machete, y todo tipo de riñas tanto en las zonas urbanas como rurales del departamento; noticias que a diario mostraba la prensa en su página principal y en la página roja. De manera dramática, los editoriales registraban con preocupación que la violencia y la barbarie se habían desatado nuevamente en los campos colombianos, como si en realidad no se hubiera avanzado mucho en la pacificación prometida por los militares $^{227}$.

De la misma forma, desde los partidos políticos tradicionales se hacían llamados a renovar los pactos de concordia política, mientras que, desde las páginas de El Siglo, el expresidente Laureano Gómez descalificaba de manera vehemente los integrantes y las decisiones de la ANAC. A su vez, los editores de El Diario invitaban a sus lectores a cerrar filas con el Gobierno militar para enfrentar las fuerzas oposicionistas del veterano jefe conservador.

227 El Diario [Pereira], 8 de junio de 1954: 4. En el referido editorial se dice lo siguiente respecto a la ola de violencia que resurgía en la región: «Influyen para esta molesta situación varios factores adversos, sobre todos los cuales es necesario alertar a la ciudadanía: el primero de ellos — y desde luego el más grave - es el de la pavorosa herencia que aún subsiste en el país, de las calamitosas épocas que antecedieron a la llegada del actual gobierno; los bandoleros que infestaban a la República y que vivían del crimen, [...], no han sido definitivamente aislados del ambiente social; todavía quedan restos por ahí de esa basura miseranda que dominaba el país, porque tenía en sus manos las armas y las usaba en la emboscada y en la traición; segundo factor, la falta de una tenaz campaña de desarme que se ejerza sin timideces en los poblados y en los campos; cada individuo lleva con sin igual desenfado un revólver, dos cuchillos y cuatro peinillas, [...], y mientras tal labor no se realice, es imposible evitar la mortandad trágica que tanto nos consterna y duele. Tercer factor: el excesivo consumo de licores destilados, pues que a ello contribuye en forma incalculable el alto precio del café que es el elemento básico de entradas para todo el mundo, pero especialmente para los campesinos y finalmente $-\mathrm{y}$ esto hay que escribirlo sin rodeos y tapujos - la poca o la ninguna acción de las autoridades cuya ausencia de los lugares de farra, disipación y riña es tan notoria como la salida del sol». Por la misma razón, desde estas columnas editoriales le exigían al comandante del Batallón Nro. 4 San Mateo - que tomara medidas más enérgicas que ayudaran a contener «la pavorosa ola de violencia desatada en las últimas horas». 
FigURA NRO. 15. Pereira adhiere y respalda al Excelentísimo Sr. Presidente Rojas Pinilla.

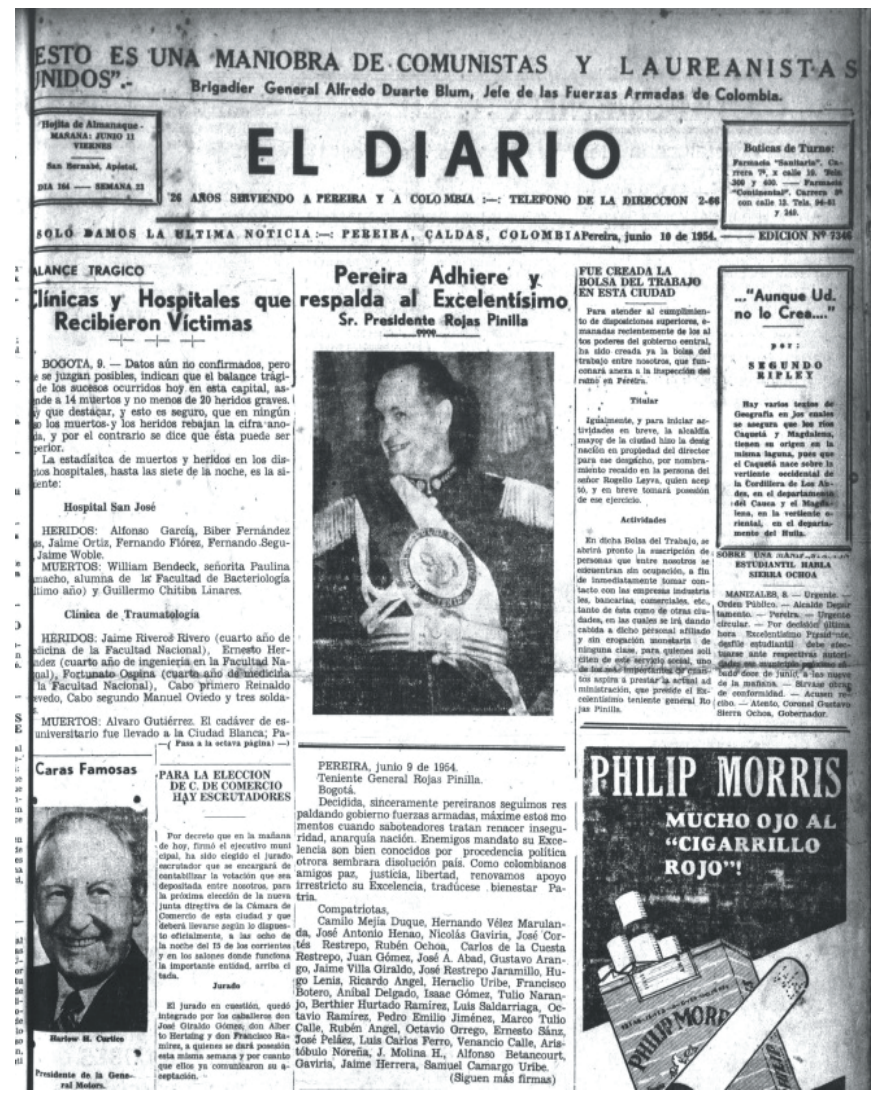

Fuente: El Diario [Pereira], 10 de junio de 1954.

En medio de esta deriva política y del recrudecimiento de los hechos de sangre, los medios y algunos sectores de la sociedad civil empezaron a retomar las posturas extremas y sectarias que se habían buscado apaciguar un año atrás con la llegada de las botas militares a la presidencia de la República. Las noticias y las notas editoriales de los periódicos regionales daban cuenta de las nuevas discordias políticas entre liberales y conservadores, las cuales surgen de la conformación de la ANAC, de los nombramientos de alcaldes y gabinetes de gobierno departamental, e incluso, por los procesos de paz adelantados por parte del gobierno nacional 
en varias regiones del país como los Llanos Orientales, Tolima y Antioquia ${ }^{228}$.

Figura NRo. 16. Portada del periódico El Diario.

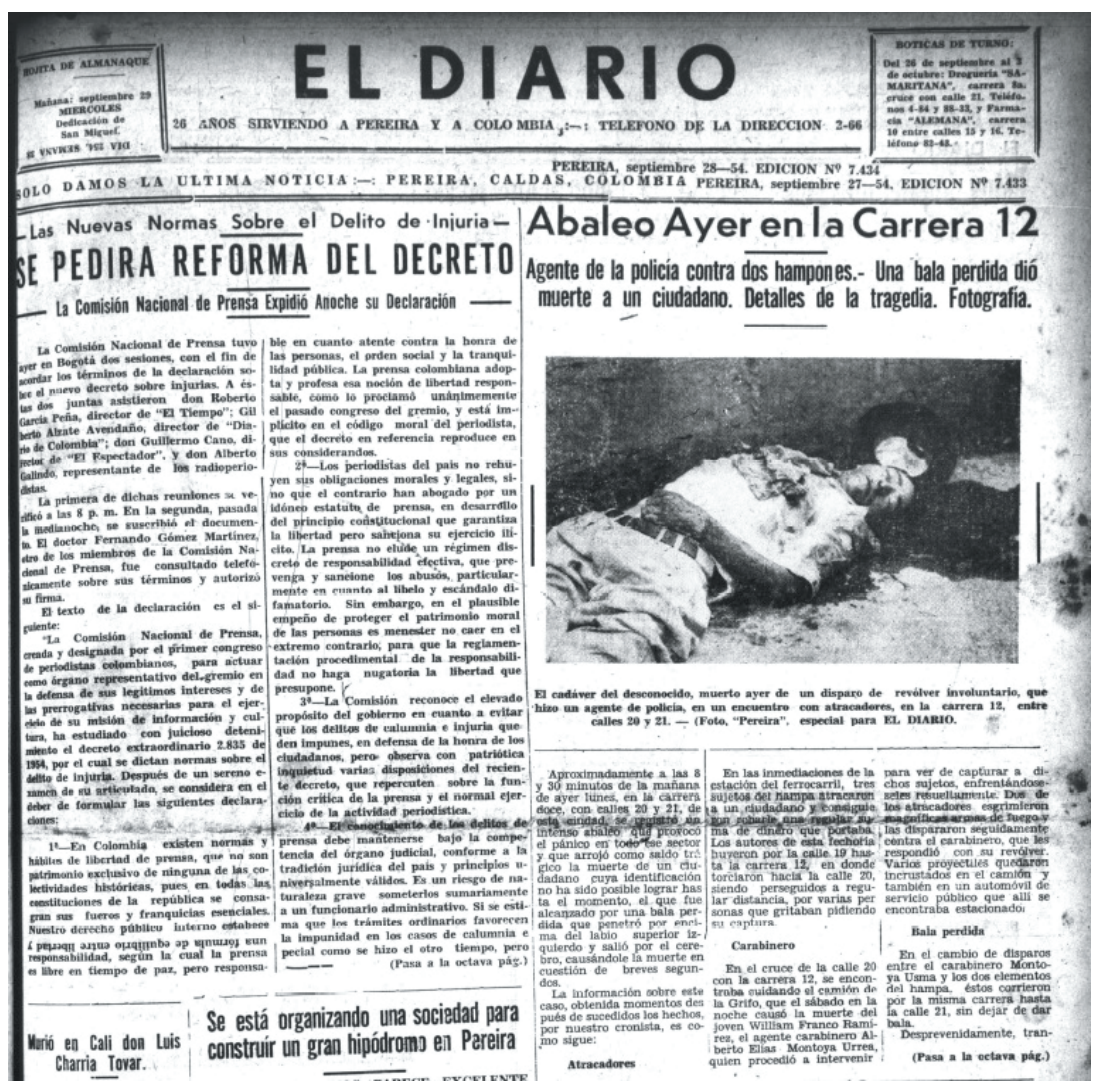

Fuente: El Diario [Pereira], 27 de septiembre de 1954.

\subsection{El Binomio y la Tercera Fuerza en marcha}

Así nació el 13 de junio de 1953, es decir una Nueva Era para la Patria que agonizaba clavada en los maderos de la más incruenta lucha fratricida ${ }^{229}$.

228 Rocío Londoño, Juan de la Cruz Varela. Sociedad y política en la región de Sumapaz (19021984) (Bogotá: Universidad Nacional de Colombia, 2014), 507.

229 El Binomio [Calarcá], 30 de junio de 1956: 2. 
Como se señaló al comienzo, El Binomio era un periódico de circulación semanal que se editaba desde el municipio de Calarcá (Caldas) con el propósito de divulgar con «encendida devoción» las labores del Gobierno militar a nivel nacional y departamental. Cabe señalar que entró en funcionamiento cuando el mandato de Rojas Pinilla acusaba un cierto desgaste político que se expresaba en un inconformismo creciente en diversos estamentos y sectores de la población civil, los cuales empezaban a señalarlo como un caudillo personalista y dictador autárquico. De ahí que la tarea del periódico se concentrara en hacer una defensa fervorosa de la labor pacificadora de las Fuerzas Armadas al frente de los destinos de la nación. No es mera casualidad que hubiera empezado a circular un 30 de junio de 1956, después de la celebración de los tres años de la llegada de Rojas al poder.

Desde la primera editorial se hizo manifiesto el interés propagandístico del semanario. Bajo el título «Objetivos», los editores enunciaron claramente que buscaban «llenar en esta sección de la Patria un vacío de propaganda y defensa de los postulados y actos de un gobierno que, como el actual, lucha sin tregua por salvar a Colombia de su aniquilamiento». La publicación también cumplía con un propósito «esperanzador», en tanto buscaba

... levantar la moral de los que débiles, se sienten zozobrar porque aún quedan humos de los vivacs de las guerrillas que con malos hijos de la Patria han querido herirla en su propio corazón, o de aquellos que locos o perversos, sueñan con el retorno de las preeminencias políticas, para implantar la persecución y el atropello ${ }^{230}$.

Así mismo, en la primera entrevista con la cual abrió el primer número del semanario "oficialista», el general Gustavo Sierra Ochoa se mostraba muy complacido por el tiempo que llevaba al frente de la administración departamental, a lo que 
señalaba: «... se había alcanzado una transformación saludable en las costumbres ciudadanas del pueblo de Caldas [el cual había] correspondido sin reservas el movimiento restaurador del Gobierno de las Fuerzas Armadas» ${ }^{231}$.

En la misma entrevista, el referido militar expresó cómo entendía el concepto de Tercera Fuerza. Para el mandatario se trataba de un movimiento de unidad en torno a los más altos y nobles ideales de la República, muy distinto al espíritu de partido que identificaba como «agrupaciones de secta que han envenenado la conciencia de los colombianos». Esta opción política era, según sus palabras,

... una fuerza poderosa de las gentes capaces y honestas en busca de los derroteros supremos de la Patria tradicional [...] una fuerza para respaldar al Gobierno en su programa de renovación pública. Para que haya una Patria amable y para que no haya ningún colombiano sin techo, educación y pan $^{232}$.

En síntesis, eran los postulados de una nueva vía que se abría para transformar a Colombia. Sin embargo, era evidente que la situación de orden público distaba del ambiente de pacificación que promovían las autoridades militares. En la página final de la primera edición de este periódico se publicaba, de manera amplia, una oferta de amnistía para los bandoleros y guerrilleros que aún seguían delinquiendo en las veredas del departamento. En el mismo anuncio se comentaba que dos bandoleros (a. «Nivel»y a. «El Gringo») se habían sometido a las autoridades y, por tanto, gozaban de libertad ${ }^{233}$. 
Figura NRO. 17. Noticia sobre el orden público en Calarcá.

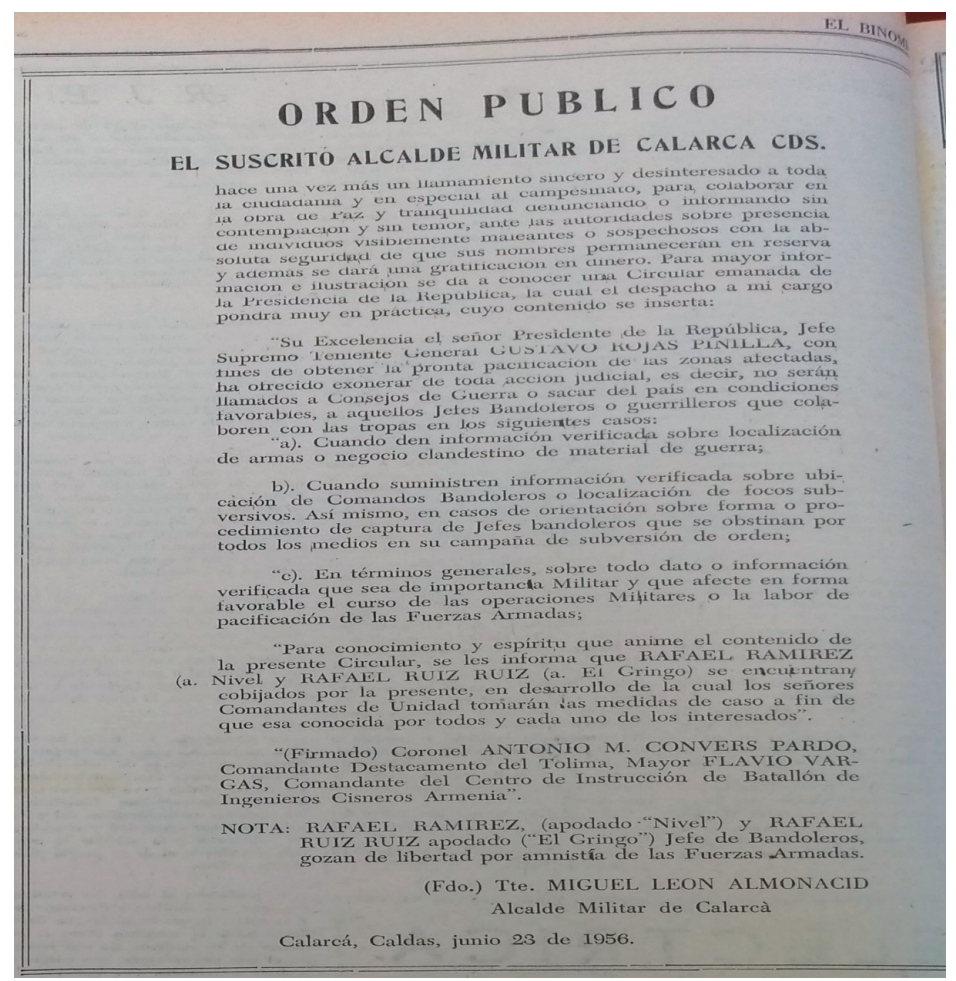

Fuente: El Binomio. Pueblo-Fuerzas Armadas [Calarcá], 23 de junio de 1953.

Pero, al parecer, la labor de pacificación no daba los resultados esperados, lo que podría poner en cuestión la eficacia de la presencia de las FF.AA. en la región. Aparentemente, no era suficiente apelar al recurso de la amnistía ni de la delación, incluso al anunciarse la gratificación en dinero. Lo anterior motivó a los redactores de El Binomio a señalar la «complicidad punible» de muchas personas en las zonas rurales respecto al accionar de la denominada chusma, lo cual puso en cuestión los ideales de unidad y compenetración entre la sociedad civil y sus fuerzas armadas. La denuncia hecha en el periódico sobre esta situación, en la que se señalaba abiertamente y sin tapujos la complicidad - fuera por miedo o simpatía - de los campesinos con las organizaciones 
violentas, invitaba a pensar en los secretos y estrechos lazos que mantenían los grupos armados ilegales con la población civil, lo cual fue sin duda uno de los obstáculos más grandes que trató de superar el Ejército mediante la acción-cívico militar para poder penetrar entre aquella población. Así lo expresaba el periódico:

Se puede afirmar que una gran mayoría de las gentes de cada región, saben cuándo va a atacar la chusma, que tiene la juiciosa y amable atención de avisar a sus copartidarios sobre los hechos trágicos que van a suceder. Entonces los copartidarios agradecidos se retiran de la comarca y les guardan el secreto, mientras en una acción rápida y aciaga los asesinos dejan desolada una región, tendidos y muertos muchos inocentes. Apenas ocurrido el hecho, con una tregua prudente, la comarca se puebla de nuevo y continúa la vida ${ }^{234}$.

Sin embargo, la idea de la Tercera Fuerza que buscaba encarnar El Binomio en sus páginas se asentaba sobre una concepción muy cercana al Partido Conservador, en sus valores morales católicos y en la mística de un patriotismo que no cesaba de reivindicar la memoria de Simón Bolívar como fundador de la República ${ }^{235}$.

Estas ideas de unidad eran pronunciadas con vigor y con una fuerza autoritaria, propia del régimen disciplinario del Ejército que enseñaban a obedecer y a mandar y decía: «Somos una especie de frente nacional contra todos aquellos que han ido matando la Patria. A ello se agrega que confesionalmente la TERCERA FUERZA [sic] es un movimiento de derechas para rescatar los auténticos valores en peligro» ${ }^{236}$.

En su labor propagandística, en los sucesivos números de la publicación gobiernista, no deja las hipérboles políticas con las que los periodistas de El Binomio buscaban ilustrar el paso de la

234 El Binomio [Calarcá], 8 de julio de 1956: 1.

$235 \mathrm{Al}$ respecto, es útil referenciar el artículo de Rubén Sierra Mejía, «La lectura conservadora de Bolívar». En La restauración conservadora, ed. por Rubén Sierra Mejía (Bogotá: Universidad Nacional de Colombia, 2012), 81.

236 El Binomio [Calarcá], 8 de julio de 1956: 3. 
oscuridad a la luz que se dio con la llegada del nuevo régimen de Rojas, como si se tratara de una lectura sacra e iluminadora de la historia de Colombia, la cual defendían los editores del periódico tres años después del golpe militar en contra de Laureano Gómez. Un ejemplo de esto se encuentra en una colaboración de Michaelo para El Binomio, en la que se afirmaba lo siguiente: «El colombiano fue lobo para el colombiano, ambiente abonado para la anarquía, cordero propicio para las doctrinas comunistas. En estos veinte años hemos recogido los frutos de lo que hemos sembrado: muerte miseria y degeneración» ${ }^{237}$. En ese ambiente lúgubre y desesperanzador refulgía con luz propia el Ejército de Colombia - casi que libre de pecado original—, para contribuir a dar una nueva personalidad al ser colombiano y a sus modos de relacionamiento social. Por tanto, se decía:

Disuelto el colombiano en su concepto interior, disuelto en su concepto de relación con sus semejantes, sólo [sic] quedaba un organismo, el Ejército, nacido en las entrañas del pueblo, aislado de la vida pública y política, en donde se ha ido guardando las reliquias de la Patria y conservando la memoria de ellas: la Bandera, el Escudo y el Himno Nacional. Allí se guardaba el amor por la Patria [sic]y se moldeaba una personalidad en los principios fundamentales de la Religión [sic], se enseñaba a obedecer y a mandar. Y ese organismo fue el escogido por Dios para que el 13 de junio salvara al país ${ }^{238}$.

Lo cierto es que, a pesar del lenguaje pacificador promovido en las páginas del periódico y su plena identificación con el régimen restaurador - también pacificador - de Rojas Pinilla, en sus columnas, se llevaba a cabo un ataque frontal contra cualquier fuerza política o medio de comunicación de oposición. En esa medida, se puede decir que este diario buscaba movilizar sentimientos y pasiones mediante la construcción de una identidad política que, como se ha visto, sentaba sus bases en la fecha del 13 de junio de 1953, en el fervor religioso y la fidelidad 
a los símbolos patrios. Pero, al mismo tiempo, otro elemento que ayudó a configurar las identidades políticas y las adhesiones a Rojas Pinilla a través de las páginas de este periódico fueron los reiterados señalamientos a los enemigos del Gobierno que, por antonomasia, también eran enemigos del pueblo, como se puede ver en el recorte de prensa de la FIgURA NRO. $18^{239}$.

Figura NRO. 18. Los enemigos del gobierno y del pueblo.

\section{ENEMIGOS DEL GOBIERNO Y DEL PUEBLO}

Defendemos con ahínco la obra paci- to y la desolación en los hogares colomficadora del Gobierno de las Fuerzas Ar- bianos.

madas. Defendemos su obra administra- Tercero: Son enemigos del Gobierno tiva subrayada de encendido afán y calli- y del pueblo, los predicadores de retado sabor humano. Defendemos su ejerci- liación y de venganza, que patrocinan la cio justiciero que emprende con "santa infernal empresa de asesinar a sus semeira" la vapulación de los vicios y la en- jantes.

mienda moral del pueblo, castigando sus Cuarto: Son enemigos del Gobierno y desvíos sin blanduras de conveniencia ni del pueblo, los saqueadores e incendiaprivilegios irritantes. Y lo defendemos rios que arruinan la Patria, destruyendo con coraje y con razón porque nos asis- a fuego nuestras empresas cafeteras y ten la tazón y el coraje.

Por tal motivo, denunciamos ante el acumulado de muchos años y de muchas Gobierno y el pueb'o, a los enemigos de generaciones.

la epopeya restauradora, emprendida con Quinto: Son enemigos del Gobierno alborozo mesiánico y tintes de cruzada y del pueblo, y además, traidores al Gomística desde el 13 de junio de 1953.

Primero: Son enemigos del Gobierno y del pueblo, los bandoleros que asesinan en emboscadas cobardes a los agentes y funcionarios del Gobierno y a los campesinos humildes.

Segundo: Son enemigos del Gobierno y del pueblo, los "pájaros" de todos los
matices políticos, que siembran el espany del, pueblo, los "pájaros" de todos los
matices políticos, que siembran el espanbierno $\mathrm{y}$ al pueblo, los que aprovechan ciestas ventajas para cometer toda clase de depredaciones y desafueros contra la vida y los bienes de los asociados.

Sexto: Son enemigos del Gobierno y del pueblo, los empleados indolentes; los desidiosos y los tolerantes que se cruzan Pasa a la página 8

Fuente: El Binomio. Pueblo-Fuerzas Armadas [Calarcá], 22 de julio de 1956.

239 El Binomio [Calarcá], 22 de julio de 1956: 1, 8. 
Bajo esta lógica, no cabía duda de que todo ciudadano de bien debía estar profundamente comprometido con la nueva senda pacificadora iniciada por el gobierno, la cual incluso llegó a ser valorada, en no pocas ocasiones, una verdadera revolución social. Estar en oposición de las actuaciones del gobierno, tanto a nivel nacional como regional, era hallarse en contra de la paz, sobre todo de esa paz cristiana que decía: «la paz sea con vosotros». De igual modo, a pesar de la larga lista de potenciales y reales enemigos del pueblo, lo interesante es observar que en esta columna se reproducía el tono crítico que algunos sectores de la cúpula militar empezaron a enfilar en contra de las oligarquías tradicionales del país, las cuales querían — según los columnistas y editores de El Binomio - «torpedear» la gestión de las administraciones militares regionales y, por supuesto, la del Gobierno nacional en cabeza del líder Rojas Pinilla. En el tono mesiánico de muchas de las columnas del semanario se argumentaba que, bajo ningún motivo, ni ninguna nueva causa nacional, se debería volver al pasado, ya que eso significaría generar una nueva "zozobra», la cual podría volver al país al pasado y detener el rumbo hacia el futuro promisorio que representaba el régimen de marras. En ese sentido, la labor de El Binomio se enfocó en la faceta de mostrar al pueblo «quiénes eran sus defensores y quiénes sus explotadores» ${ }^{240}$.

Número tras número, la defensa de las acciones del gobierno no cesaba de aparecer en El Binomio, al mostrar una clara vocación política conservadora, de derecha y anticomunista. En un editorial del 29 de julio de 1956, titulado «Receso Obligado» ${ }^{241}$, se hacía un balance muy preocupante sobre la situación del país en el cual, como se dice coloquialmente, "no quedó títere con cabeza». Lo anterior también daba muestra de la frustración que, en muchos instantes, embargaba los ánimos de los editores al momento de dirigirse a sus lectores. 
Se cuestionaba, en primer lugar, el desarrollo capitalista de corte liberal que, bajo las «ideas del predominio del capital sobre el trabajo, la jornada de seis a seis, el salario bajo, la miseria del pueblo [...] vio en las doctrinas de Marx su tabla de salvación ${ }^{242}$. Pero, a renglón seguido, también arremetían contra ciertos intelectuales -en una visión un tanto exagerada- que recorrían los campos y ciudades de todo el país para influenciar las clases populares con su «criterio disociador». Así mismo, y en un tono bastante moralizante, se cuestionaban las reformas políticas llevadas a cabo durante la República Liberal (1930-1946) las cuales, en su aparente afán modernizador, quitaron «... de en medio todo lo tradicional» y llevaron a que «los maestros no enseñaran religión y a que tampoco los niños asistieran a misa en comunidad los domingos». Estas imágenes propias de una sociedad basada en los vínculos de solidaridad mecánica planteaban muy serios cuestionamientos a la inminente ruptura del orden social y señalan que en Colombia «el materialismo se había entronizado en la sociedad colombiana» y había posibilitado la formación de un pueblo sin Dios ni principios de autoridad, el cual atravesaba por una especie de Edad Pagana en la que, como se expresaba en el periódico El Binomio,

... los derechos reinaron sin tener en cuenta los deberes [...] y se revelaron los de abajo y de todas las capas sociales salieron unidades para ingresar al ejército de descontentos, creando una fuerza contra la fuerza misma del Estado, llevando el exterminio sobre los que no querían ingresar en su grupo ${ }^{243}$.

Aunque también cuestionaban la incapacidad de los partidos políticos para reaccionar contra la situación de violencia política que ellos había generado; es claro que los editores de El Binomio atribuían la mayor responsabilidad sobre el comunismo referenciado así en términos bastante genéricos-, como la causa principal de la violencia y contra la cual luchaba, denodadamente, el régimen militar en las distintas regiones del país.

242 El Binomio [Calarcá], 29 de julio de 1956: 3 243 El Binomio [Calarcá], 29 de julio de 1956: 3. 
No obstante, a pesar de los múltiples altibajos en el proceso de pacificación territorial, el Consejo Administrativo del departamento de Caldas, reunido en la ciudad de Manizales el 6 de julio de 1956, le brindó una total adhesión al general Rojas Pinilla y postuló su candidatura presidencial para el periodo 19581962. En un comunicado que salió publicado por diversos medios de prensa, dicho Consejo le solicitaba al gobernador Sierra Ochoa que aceptara ser el mensajero del comunicado y el «... portavoz de los sentimientos que el pueblo caldense tuvo para elaborarla y presentarla a la consideración de la nación ${ }^{244}$.

En ese momento, la batalla política y publicitaria que libraba El Binomio ya estaba casada. En aquellos meses el ambiente político del país se puso más tenso debido a las disconformidades con el régimen autoritario de Rojas y su eventual candidatura a la presidencia, lo cual despertaba el temor entre liberales y conservadores. El 24 de julio de 1956 se habían reunido en la ciudad española de Sitges el líder conservador — en el exilio Laureano Gómez y el líder del Partido Liberal, Alberto Lleras Camargo para crear una alianza política entre ambos partidos, la cual les permitiera desplazar a Gustavo Rojas Pinilla, al que consideraban un dictador y, así, retornar a la institucionalidad democrática y republicana ${ }^{245}$.

Lo anterior mereció los comentarios más ácidos por parte de los periodistas de El Binomio. Estos denunciaron, de la siguiente forma, aquello que ellos consideraban una nueva treta política de la oligarquía:

Nunca se había visto más al desnudo la lacería de nuestros estamentos políticos o mejor politiqueros. Porque ese coctel amorfo, hibrido, revoltura de intereses, no será, no puede ser, ni conservatismo ni liberalismo. Para atacar a la Tercera Fuerza no va a ser posible coalición de clase alguna. El pueblo ya tiene conciencia de cómo se están manejando sus destinos y está contento ${ }^{246}$.

244 El Binomio [Calarcá], 22 de julio de 1956: 5.

245 Gabriel Silva Luján, «El origen del Frente Nacional y el gobierno de la Junta Militar». En Nueva Historia de Colombia, ed. por Jorge Orlando Melo (Bogotá: Editorial Planeta, 2001), 197. 246 El Binomio [Calarcá], 5 de agosto de 1956: 1. 
En los meses siguientes, El Binomio mantuvo una especie de rifirrafe con otros medios de comunicación regionales y nacionales. Convirtieron sus noticias y columnas de opinión en trincheras periodísticas para defender el modelo militar pacificador que ya proyectaba con perpetuarse en el poder. En medio de la información sobre un sinnúmero de actos públicos, fiestas patrias y otros rituales políticos, el periódico no desaprovechaba la oportunidad de acentuar la idea de un enemigo interno que, en este caso, ya no era el comunismo, sino lo que con tono irónico denunciaban como el ejercicio demagógico de «manes mitológicos», refiriéndose a «los lopistas, lleristas, gomistas, ospinistas y alzatistas». Es claro que, a la vez que los editores de El Binomio cuestionaban los personalismos de los cuales hacían gala ciertas facciones políticas de ese momento, tanto en el partido liberal como en el conservador, tampoco se medían en hacer una ponderación excesiva respecto a los méritos reales de Rojas Pinilla y su régimen de gobernadores militares. La cultura política del momento se debatía en múltiples frentes y uno de ellos tenía que ver con la idea del «carisma» político que encontraba, en las portadas y en las páginas editoriales de la prensa nacional y regional, un escenario clave para el despliegue de las exaltaciones propias del culto a la personalidad, así como los anatemas en contra de aquellos que se asumían como el enemigo visceral a vencer. No cabe duda de que la construcción de la relación amigo-enemigo era fundamental en la arena política. De esta manera, tiene sentido pensar en términos de lo que Angelo Ventrone define como «la execración» del adversario o rival político que, según él, es algo usual a muchas culturas políticas modernas donde, como parte de su estrategia política y publicitaria, construyen su «propia identidad en negativo» al llamar la atención, de la comunidad que representan, sobre los 
peligros que pueden representar en un momento dado aquellos que tienen una concepción diferente u opuesta del mundo, del orden social o del cambio político ${ }^{247}$.

\subsection{El Binomio durante la etapa de Daniel Cuervo Araoz}

El 29 de septiembre de 1956, cuando Sierra Ochoa había cumplido tres años al mando de la Gobernación de Caldas, este fue enviado por Rojas Pinilla a la Gobernación de Antioquia, en reemplazo del mayor general Pioquinto Rengifo. Cuatro meses después, el 28 de enero de 1957, Sierra Ochoa fallecería en un «oscuro» accidente aéreo, según afirma Orlando Cadavid Correa, «... cuando se perfilaba como el posible sucesor de Rojas en el Palacio de San Carlos» ${ }^{248}$.

Al momento de su partida de tierras caldenses, El Binomio, con una emotiva consigna de «SIEMPRE FIRMES, MI GENERAL [sic]», señaló lo siguiente: «Sierra Ochoa sembró en un pueblo que sabrá hacer de su nombre un programa y una bandera ${ }^{249}$. Una semana antes, al conocerse la noticia de su nuevo nombramiento para la Gobernación de Antioquia, se afirmó que Caldas volvía «... a ser el Departamento Modelo [sic] [bajo su mando] por su incasable denuedo y empeñoso [sic] laborar infatigable» ${ }^{250}$.

Tras la partida del reconocido militar Sierra Ochoa, llegó a asumir las riendas del conflictivo departamento de Caldas el

247 Angelo Ventrone, «El enemigo interno. Perspectivas historiográficas y metodológicas». En Historia cultural de la política contemporánea, ed. por Jordi Canal y Javier Moreno Luzón (Madrid: Centro de Estudios Políticos y Constitucionales, 2009), 243. Según este mismo autor, la figura del enemigo se construye - en la prensa, por ejemplo- mediante la «circulación notable de los mismos eslóganes, los mismos símbolos y las mismas representaciones» (245). Y, además, otro elemento que aparece constantemente en las representaciones del enemigo interior son las acusaciones - con distinto grado de acritud - sobre el peligro que encarna el triunfo o la llegada al poder de dicho enemigo, el cual pondría en riesgo los cimientos de la sociedad constituida o el pacto político sellada entre sus líderes y seguidores (246).

248 Cadavid Correa, «Los nueve gobernadores...», https://www.eje21.com.co/2016/03/los-nuevegobernadores-militares-de-caldas/.

249 El Binomio [Calarcá], 29 de septiembre de 1956: 4.

250 El Binomio [Calarcá], 22 de septiembre de 1956: 1. 
coronel Daniel Cuervo $\mathrm{Araoz}^{251}$, quien permaneció en el cargo hasta el 12 de mayo de 1957, cuando Rojas Pinilla tuvo que abandonar el solio presidencial y en su reemplazo asumió la Junta Militar ${ }^{252}$. Al asumir Cuervo Araoz - quien venía de desempeñarse como ingeniero militar en el plan de carreteras y en la construcción de una pista de aterrizaje en la zona del Sumapaz- ${ }^{253}$, El Binomio también cambió de dirección. Con la posesión del antiguo director Luis Alfonso Peña en el cargo de alcalde de Calarcá, fue nombrado sucesor Antonio J. López García.

El nuevo encargo de la dirección del semanario a López García no significó un cambio drástico en la orientación del periódico, ya que se mantuvo el apoyo irrestricto a la gestión del nuevo gobernador Cuervo Araoz y, por supuesto, a la labor de Rojas Pinilla. Sin embargo, el ambiente político y la situación de orden público estaban bastante caldeadas a nivel nacional y regional. Los editores del rotativo registraban, con bastante excitación y emotividad, las problemáticas y debates que se estaban presentando a finales del año 1956; sin dejar de apoyar frontalmente la causa de la Tercera Fuerza. Desde la página editorial se continuaba haciendo constantes llamados a la unidad y a no desfallecer ante la misión que la historia le había asignado a su generación.

No obstante, la tarea periodística e ideológica distó mucho de ser exitosa. Como se mostró anteriormente, los hechos de violencia no daban tregua en las diferentes subregiones del departamento, especialmente en los municipios del sur, los cuales, más adelante,

251 Daniel Cuervo Araoz se desempeñó en el año 1943 como alcalde mayor y jefe civil y militar de Cúcuta. Fue director de la Escuela de Cadetes General Santander en el año 1951 y gobernador de Caldas entre el 29 de septiembre de 1956 y el 12 de mayo de 1957. Su gobernación se caracterizó por las medidas represivas que utilizaba para disolver manifestaciones, las cuales le costaron el apodo de «Cuervo Atroz», especialmente entre los manizaleños. A su salida de la Gobernación no obtuvo otros cargos de relevancia. Ver: Cadavid Correa, «Los nueve gobernadores...», https:// www.lapatria.com/columnas/70/los-nueve-gobernadores-militares-de-caldas; Héctor Álvarez Mendoza, «La Policía Nacional el 9 de abril de 1948», EJE 21, 11 de marzo de 2018, https://www. eje21.com.co/2018/03/el-senor-de-las-culebras/.

252 Adolfo León Atehortúa, «El golpe de Rojas y el poder de los militares», Folios, n. ${ }^{\circ} 31$ (2010): 33-48.

253 Londoño Botero, Juan de la Cruz Varela..., 522. 
formarían el departamento del Quindío a partir del año 1966. En una editorial titulada "Qué épocas y Qué gentes», a propósito del recrudecimiento de la violencia en Génova, Pijao y Calarcá, el director del periódico evidenciaba una mezcla de desazón y desmotivación por la pobre respuesta que obtenían los llamados de pacificación de las autoridades militares entre la población civil. Sin hacer una mínima referencia sobre las denuncias acerca de los posibles abusos de la fuerza pública en la región, El Binomio optó por denunciar públicamente la falta de sensibilidad de los pobladores ante el drama de muchos de sus vecinos, así como el poco apoyo, el desapego y la falta de respeto a las autoridades militares en su propósito de pacificar la región. En este sentido decían:

Y no hay que echar a las autoridades la culpa. La culpa la tiene una sociedad ya insensible y egoísta que ni vigila ni se espanta deseosa de que las cosas se agraven para poder hablar mal de los gobernantes. Un odio cerrado a nuestras instituciones convierte en altanería la angustia y no hay sinceridad ni humildad cristiana para clamar ayuda, pedir socorro y defender los restos que nos van dejando los asesinos. [...]

Es preciso convencernos de que la salvación, inclusive la física, no nos viene de nadie sino de nosotros mismos. Mientras no reformemos nuestros hábitos y no hagamos una nueva conciencia, la podre $[s i c]$ seguirá cundiendo como una peste incontenible. Tenemos que empezar por reformarnos a nosotros mismos, si queremos ver reformada nuestra sociedad, pacíficos los campos, productoras las cosechas. Los actuales son síntomas de esterilidad moral y de esterilidad material. Los tiempos que corren sólo [sic] son jugosos para los usureros, para los prostibularios y para los que negocian con la muerte. [sic] ¡iQué época, qué tierra y qué gentes!! $[s i c]^{254}$.

254 El Binomio [Calarcá], 20 de octubre de 1956: 3. 
El cuadro anterior no podría ser más dramático. La opinión de El Binomio daba cuenta de una sociedad diluida, sin una personalidad social clara en medio de una esterilidad moral y material. Entre líneas se puede evidenciar cierto desdén y distanciamiento de las autoridades militares. La tarea emprendida por Rojas Pinilla y sus lugartenientes en las regiones no había alcanzado los propósitos que se buscaban y, en muchos aspectos, terminaron por deslegitimar la propia acción cívico-militar del Ejército en las diferentes localidades de la región. Las autoridades tomaban una serie de medidas que a la larga se mostraban infructuosas, como cuando se levantó la prohibición de andar con ruanas en los poblados ${ }^{255}$.

$\mathrm{Al}$ respecto, se hace útil referenciar las conclusiones opuestas a las cuales llega Carlos Miguel Ortiz, quien señala que a pesar del lenguaje de unidad propagado en los discursos públicos y en la prensa regional, los militares a cargo de la gobernación, las alcaldías y las diferentes guarniciones militares «fueron presa, en buena parte, del gamonalismo local con sus fragmentarias querellas provincianas». También señala que, las fuerzas del Ejército se prestaron para «... la discriminación sectaria, [la] cohonestación oficial de actos delictivos, [la] interferencia de diferente suerte de pugnas localistas dentro del ejercicio de la autoridad, y, en términos genéricos, [la] arbitrariedad en la administración de justicia, tanto civil como militar» ${ }^{256}$. Incluso, dicho autor cita una versión de un mayordomo de una vereda de Pijao, en la cual algunos miembros del Ejército se prestaban para actos de bandolerismo en la zona.

\footnotetext{
255 El Binomio [Calarcá], 3 de noviembre de 1956: 7. Al respecto, en la columna «Comentarios Breves» se señala lo siguiente: «... creer que todo tipo que se arropa con la clásica ruana lleva oculta debajo de ella o un revólver presto a disparar o un puñal con el cual se dispone a herir, es no conocer absolutamente nada de la psicología de las gentes y más cuando éstas [sic] son caldenses de nacimiento o antioqueños raizales. Al antioqueño y al caldense, [...]les fascina usar la ruana, adminículo que entre otros muchos usos tiene el de servir de abrigo contra el frío y, en no contadas ocasiones, de cobija. Hay personas para quienes la ruana es una necesidad imperiosa y carecer de ella es sentirse teóricamente desnudas».

256 Ortiz, Estado y subversión..., 275, 277.
} 
El Binomio continuaría defendiendo hasta el final su tarea pacificadora del régimen de Rojas Pinilla. Según los periodistas de este medio, Rojas tenía el mérito de haber logrado «recomponer», desde el punto de vista político y social, las jerarquías anquilosadas entre las clases populares subyugadas y las «elites agonizantes», las cuales querían volver al poder ${ }^{257}$. A pesar de la ola incontenible de violencia que azolaba - como una cabeza de hidra- diferentes regiones del departamento, el referido periódico no dudaba en calificar a Cuervo Araoz como un apóstol de la paz, a quien el pueblo de Caldas y en especial del Quindío le debían una enorme gratitud por recuperar la calma social y el orden público ${ }^{258}$.

El 10 de mayo de 1957 llegaría a su fin la presidencia de Rojas Pinilla quien pasó, de manera vertiginosa, de salvador a dictador. Los periódicos daban cuenta del hecho con letras de molde en primera plana, y hacían referencia a las enormes manifestaciones de beneplácito en ciudades capitales y ciudades intermedias, en las cuales se vivió un júbilo inmortal con la llegada al poder de la nueva Junta Militar. Como señala Adolfo León Atehortúa:

La historia debate si la Junta fue creada con el propósito de restablecer al General cuando las condiciones de gobernabilidad lo permitieran, o si fue instaurada de manera momentánea en el poder para asegurar la realización inmediata de elecciones presidenciales, como el mismo Rojas lo ordenó en su alocución de retiro ${ }^{259}$.

Mientras la ANAC se disolvía, las autoridades religiosas de Pereira convocaban a las masas a celebrar el acontecimiento con un solemne Te Deum en la Plaza de Bolívar (ver Figura NRo. 21) como acción de gracias, pero no sin antes advertir sobre la

257 Sobre esta lectura particular de la historia de Colombia se hicieron muchas referencias. Jorge Villaveces, uno de los más conspicuos defensores del régimen de Rojas Pinilla decía: «El binomio Pueblo-Fuerzas Armadas ha derrotado las oligarquías políticas que dominaron el país por más de 140 años») Citado por Fernando Gómez Martínez, director del periódico antioqueño El Colombiano, a quien El Diario le publicó un editorial bastante sarcástico titulado «Durante más de 140 años». El Diario [Pereira], 1 de abril de 1957: 4.

258 El Binomio [Calarcá], 12 de enero de 1957: 3.

259 Atehortúa, «El golpe de Rojas...», 44. 
necesidad de hacer presencia en dicho lugar con «paz, cordura y máxima tranquilidad. Ese es el deseo de las gentes de bien y así lo exigen los títulos de la ciudad $»^{260}$. En este nuevo orden de cosas, la Junta Militar se asumió como un paréntesis para permitir el regreso de los dos partidos políticos tradicionales a la jefatura del Estado colombiano. Varios medios de comunicación que habían sufrido la censura de parte de los militares abogaban por que volviera a tomar las riendas del departamento un gobernante civil, tal como apareció en El Diario, el 11 de mayo de $1957^{261}$ (ver Figura NRO. 19).

Figura NRo. 19. Se solicita el cambio de Gobernador Militar por un Elemento Civil.

\section{Sábado, Mayo 11 de 1957. - EDICION No. 8.359}

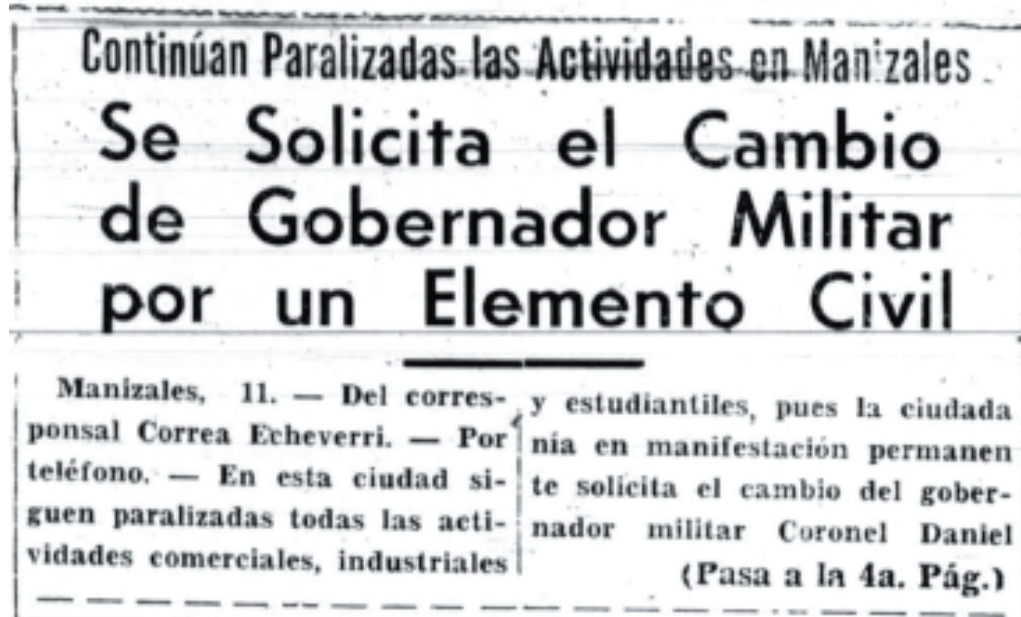

Fuente: El Diario [Pereira], 11 de mayo de 1957.

260 El Diario [Pereira], 11 de mayo de 1957: 8.

261 «El fin de la dictadura fue celebrado en ciudades y pueblos por multitudes que coreaban la consigna: “¡Un civil, botas no!”. Entre las manifestaciones de euforia popular, fueron destruidos los bustos de Rojas Pinilla puestos en las plazas de no pocos pueblos por orden de la Odipe o por iniciativa de alcaldes que buscaban congraciarse con el jefe supremo. Un curioso ejemplo de este gesto simbólico fue la decapitación del busto de la plaza de Silvania; la cabeza fue arrojada al río Chocho, de donde varios niños la rescataron para jugar con ella». Londoño Botero, Juan de la Cruz Varela..., 562. 
No obstante, la Junta Militar procedió a nombrar gobernador de Caldas al general Gerardo Ayerbe Chaux - a través de la Radiotelevisión Nacional- en reemplazo de Cuervo Araoz, de quien se rumoraba que había salido de manera sigilosa en un helicóptero desde el Aeropuerto Matecaña ${ }^{262}$.

\section{Conclusión}

Finalmente, la revisión de los discursos y la propaganda periodística del coronel Gustavo Sierra Ochoa como Gobernador de Caldas entre 1953 y 1956 tuvo lugar a partir de sus memorias sobre la gestión al frente del departamento y del semanario $\mathrm{El}$ Binomio, en el que con una muy cuidada edición se resaltaban las acciones militares tendientes a recuperar la convivencia y la paz en esta región. Al tomar el lema nacional de Rojas Pinilla de «Paz, Justicia y Libertad», el régimen militar se enfocó a nivel regional en publicar todas las obras de infraestructura y los programas sociales agenciados por el Servicio Nacional de Asistencia Social (SENDAS) con el fin de demostrar que una nueva era para la República se abría con el papel modernizador de las Fuerzas Armadas en el poder, lo cual, en su concepto, las separaba del sectarismo político que caracterizó a la democracia colombiana bajo los gobiernos partidistas. Sin embargo, los militares no pudieron mantener su neutralidad dentro del conflicto y actuar como garantes de la restitución de aquella, pues fue posible observar la intensificación de las críticas de las altas cúpulas militares acerca de las posturas sectarias y fratricidas de los partidos liberal y conservador, lo cual le permitió al Ejército vislumbrar una posibilidad de mantenerse en el poder político, situación que a la postre conllevó a crear la imagen del binomio pueblo-Fuerzas Armadas, también llamada la Tercera Fuerza Política.

A partir de 1958 y entrada la década de los años sesenta vendrían nuevos aires con el Frente Nacional, donde el Ejército

262 El Diario [Pereira], 11 de mayo de 1957: 5. 
adquirió cierto nivel de autonomía para restablecer el orden público, y eliminar el fenómeno bandoleril y guerrillero. A medida que se dejaba atrás un pasado reciente más bien ignominioso, quizás no digno de recordarse, la nación se abría a un futuro lleno de esperanza gracias al pacto firmado por arriba entre las principales figuras de los partidos tradicionales con el beneplácito de las elites del país. En general el Ejército y, en particular - para el caso que interesa - la VIII Brigada con sede en Armenia proseguían desplegando en los campos diversas estrategias militares, tal como se hizo posteriormente con el Plan $\mathrm{LAZO}^{263}$, en el cual se desarrollaban operaciones psicológicas de inteligencia dentro de la población civil. Paralelamente, se empezó a promover formas de autodefensa como el «servicio de vigilancia en las veredas y fincas; señales de alarma en las áreas rurales para dar aviso a las Bases de Patrullaje, y facilidades para adquisición y porte de armas» ${ }^{264}$.

El Ejército proseguiría en su labor de persecución de bandoleros y comunistas al destacar la eliminación física de estos primeros como el temido Chispas (Teófilo Rojas Varón) en enero de 1963, bajo el fuego de la tropa del Batallón Cisneros, en la vereda La Albania, zona rural del municipio de Calarcá.

No obstante, persistía la desconfianza ante la población campesina de la región por parte de las fuerzas militares, fuera por su complicidad con los grupos de bandoleros, por su poco apoyo a las Fuerzas Armadas, o por lo que algunos periodistas de El Binomio señalaban como una "atávica ignorancia» que los hacía presa fácil de los engaños de cualquier demagogo, fuera este un gamonal o un jefe de cuadrilla. Esta situación es un indicio de las dificultades con las cuales se encontró la Dictadura para conseguir la anhelada pacificación al igual que la politización de los militares que aspiraban construir un proyecto político más

263 Sigla utilizada por las Fuerzas Militares colombianas para hacer referencia al plan de pacificación diseñado por el teniente general Alberto Ruiz Novoa en el año de 1962. Sin embargo, en algunos documentos aparece como LASO (Latin American Security Operation), asunto que ha sido debatido en la historiografía y que gira en torno a la intervención norteamericana. Ver referencia ampliada en el tercer capítulo de este libro.

264 VIII Brigada, De la violencia..., 46. 
allá de los partidos, y de los problemas de gobernabilidad de los mismos que - en algunos casos - incurrieron en ilegalidades y abusos de autoridad.

La transición de Rojas a la Junta Militar fue recibida con beneplácito por diversos sectores políticos, gremiales, estudiantiles y de la Iglesia católica. El jolgorio colectivo dio lugar a nuevos pronunciamientos que auguraban un nuevo futuro para la nación y el renacer de la democracia extraviada y maltratada. Tras la euforia inicial, la cual trajo consigo la llegada de los militares al poder, vino la decepción y la crítica que permitió a los antiguos rivales políticos darse la mano y sellar el pacto que condujo al Frente Nacional. El Ejército persistiría en su lucha contra el bandolerismo y el comunismo. Pero queda claro que esta institución no alcanzó la pacificación total que buscaba establecer en las diferentes regiones del país, las cuales habían sufrido los flagelos de La Violencia. Por el contrario, sus unidades efectivas quedaron inmersas en la dinámica conflictiva de la época. Este reconocía sus limitaciones cuando analizaba que muchos de los recursos que el Estado colombiano debía destinar para el progreso y bienestar de la población; para atender servicios como salud, vivienda, higiene y educación; se debían dirigir principalmente «... a dotar la fuerza pública de los medios necesarios para combatir a los violentos», en una situación que, como se ve, no dista mucho del presente ${ }^{265}$.

265 VIII Brigada, De la violencia..., 24. 
FiguRA NRO. 20. Denuncias por infiltraciones de billetes comunistas.

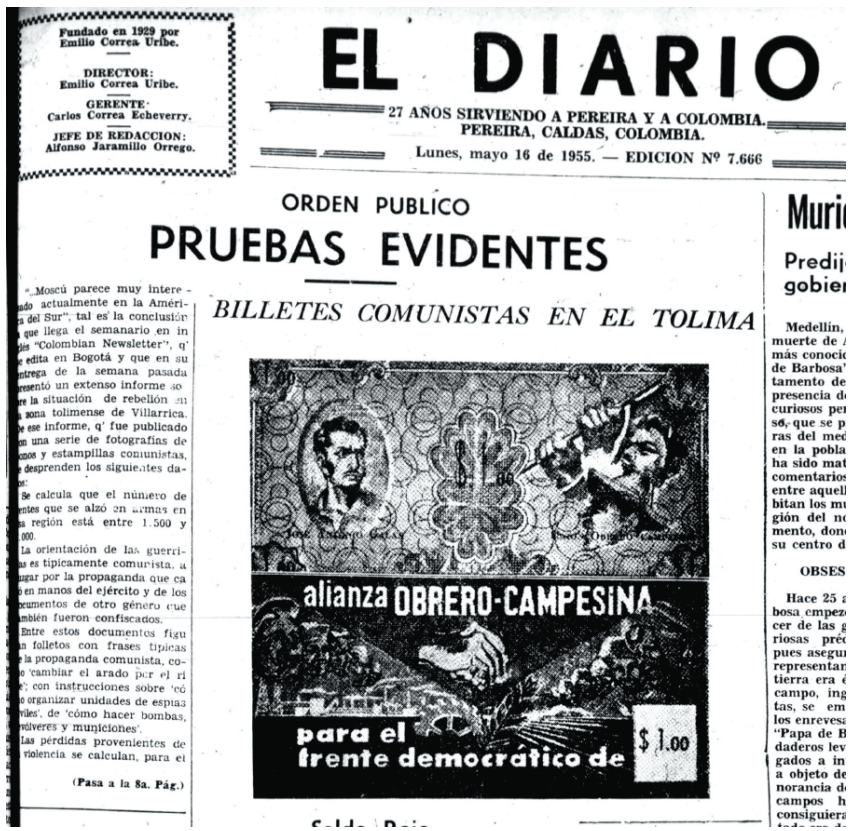

Fuente: El Diario [Pereira], 16 de mayo de 1957.

Figura NRO. 21. Te-Deum en acción de gracias por salida de Rojas Pinilla.

\section{PEREIRANOS:} En la Plaza de Bolívar. 4las 3 p. m.

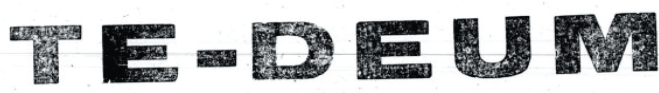
En acción de gracias. al TODOPODEROSO.

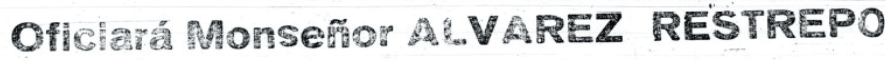

Fuente: El Diario [Pereira], 11 de mayo de 1957. 



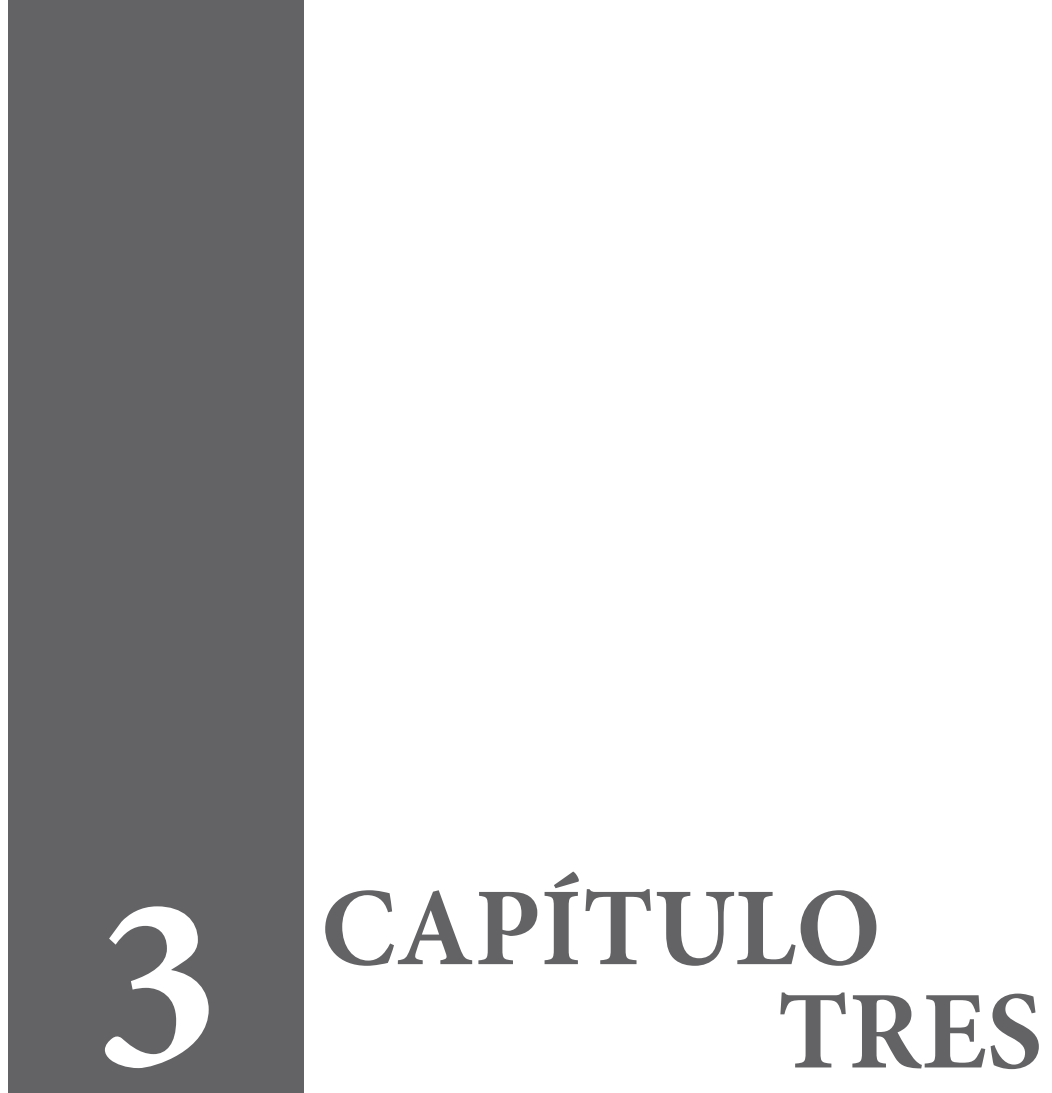





\title{
Un acercamiento a la Acción Cívico- Militar (ACM) en el departamento de Caldas (1953-1964)
}

\author{
Jhon Jaime Correa Ramírez $z^{266^{\circ}}$ \\ Natalia Agudelo Castañeda ${ }^{267^{* *}}$
}

[...] contra bandoleros y seres rebeldes y desnaturalizados, la única solución está en el fuego eficaz de las armas.

General Ayerbe Chaux ${ }^{268}$.

Este capítulo se ubica en el periodo que inicia con el ascenso al poder del teniente-general Gustavo Rojas Pinilla (1953), quien bajo el lema de «Paz, Justicia y Libertad» desarrolló una serie de

\footnotetext{
266* Doctor en Ciencias de la Educación de RUDECOLOMBIA, Magíster en Ciencia Política de la Universidad de Antioquia e Historiador de la Universidad Nacional de Colombia Sede Medellín. Profesor Titular de la Universidad Tecnológica de Pereira. Autor entre otros libros de: Civismo y educación en Pereira y Manizales (1925-1950) (2015) y Tinta Roja. Prensa politica y educación en la República Liberal (1930-1946) (2016).

$267^{* *}$ Licenciada en Comunicación e Informática Educativa y Candidata a Magíster en Historia de la Universidad Tecnológica de Pereira. Coautora del libro Facultad de Ciencias de la Educación 50 años en la construcción de un proyecto educativo para una nueva región (1967-2017) (2018) y de Resignificando la historia de la UTP. Memorias que no se jubilan (2020). Ha publicado artículos en revistas especializadas en la línea de historia de la educación.

268 Meertens y Sánchez, Bandoleros, gamonales y..., 169.
} 
acciones encaminadas a darle fin a La Violencia que azotaba al país desde varios años atrás. Luego de su mandato, el poder fue asumido por una Junta Militar interina (1957), la cual abonó el terreno para el retorno de los gobiernos civiles en el país, bajo una estrategia diseñada por parte de los dos partidos tradicionales Liberal y Conservador- que dio como resultado lo denominado, en la historia colombiana, como Frente Nacional (1958-1974). El cierre de la etapa de estudio corresponde al año 1964, momento en el cual se produjo la «Operación Marquetalia» y se vislumbraron los resultados del Plan Lazo. Así, a mediados de los años sesenta, se dio la transformación de lo que hasta ese momento se había entendido como una violencia bandoleril, hechos que, en su conjunto, le abrieron el paso a la lucha contra las nacientes guerrillas comunistas.

Para la realización de este capítulo se acudió a la revisión de los periódicos La Patria de Manizales y El Diario de Pereira; como también al escrutinio de otros documentos oficiales entre los que se encuentra la Revista Criminalidad, publicada por la Policía Nacional. Esta información fue contrastada con fuentes secundarias entre las que se encuentra la bibliografía especializada reciente y los «clásicos» que han abordado el fenómeno de La Violencia en el país y la región que nos ocupa.

El tratamiento de La Violencia por parte de los militares estuvo marcado por la intención de consolidar un concepto particular de paz. Entendida como la ausencia de confrontaciones que se lograría mediante la implementación de una serie de estrategias de pacificación, entre las que se destacaron las amnistías y la Acción Cívico-Militar (ACM). Esta estrategia les permitió a los sectores castrenses hablar de una pacificación que mezcló el uso de la fuerza y medidas políticas en los distintos departamentos, los cuales se vieron afectados por la violencia bipartidista y luego insurgente. 
En el departamento de Caldas dicha pacificación se desarrolló mediante la organización de juntas, planes de desarme, planes generales de orden público, capturas o bajas a los actores armados que se combatían - bandoleros y guerrilleros comunistas-. Ello fue posible gracias a las facultades político-administrativas, obtenidas por los militares una vez alcanzaron el poder ejecutivo, es decir, cuando el Ejército se asumió como árbitro político ${ }^{269}$ con la potestad de nombrar gobernadores, alcaldes y/o corregidores militares en los departamentos y municipios considerados prioritarios.

Así, con el estudio de las acciones cívico-militares emprendidas en el periodo mencionado- fue indispensable tomar en consideración el papel de los agentes armados y la lucha por la simpatía y la colaboración de la población civil. Como se ha visto en otros capítulos, durante esta época se le adjudicó relevancia al binomio Pueblo-Fuerzas Armadas. En este, la población se convirtió en elemento central de la confrontación entre el Estado, los bandoleros y guerrilleros con el propósito de contener el supuesto avance del comunismo internacional, concepción inscrita en los primeros años de la Guerra Fría (1945$1990)^{270}$. De hecho, en un pasaje que aparece en el periódico $L a$ Patria, el 14 de marzo de 1954, se informó en primera plana lo siguiente:

... la declaración de la décima Conferencia Panamericana estaba destinada "a salvar" a las Américas del mal más amenazante que la haya confrontado. La conferencia Interamericana aprobó por 17 votos contra uno [Guatemala] y dos abstenciones [México y Argentina], el proyecto de resolución de Estados Unidos por el cual se previenen al comunismo internacional que no trate de penetrar en el hemisferio occidental ${ }^{271}$.

269 Palacios, Entre la legitimidad..., 138.

270 Vanni Pettina, Historia Mínima de la Guerra Fría en América Latina (México: Colegio de México, 2018), 31.

271 La Patria [Manizales], «La Décima Conferencia Panamericana: Prevención al comunismo, enmienda propuesta por Colombia, aceptada», 14 de marzo de 1954. 
De acuerdo con Ugarriza y Pabón, uno de los aspectos que contribuye al entendimiento del abordaje dela amenaza guerrillerabandoleril es «... la implantación del discurso anticomunista, que ya había sido promovido por los partidos políticos desde los años veinte e instalado en la cultura militar durante los años de la dictadura hasta el año de $1958{ }^{272}$. De esta forma y como se verá más adelante, la acción cívico-militar ha sido narrada por los militares como una "operación psicológica», la cual consistía en hacerle entender - especialmente- al campesinado que la persecución por parte de las Fuerzas Armadas era cosa el pasado y en cambio se trataba de "hacer presencia del Estado» en las comunidades abandonadas a través de obras públicas y asistenciales.

Según Robert Karl, estas acciones fueron parte del intento por realizar una "paz a la criolla» ${ }^{273}$ entendida como la ausencia de fuerza física, pero en la que también estaba presente una idea de progreso local y regional relacionada directamente con la modernización. Como se sabe, el escenario internacional en el cual tuvo lugar La Violencia estuvo marcado por las teorías del desarrollismo, promovidas por intelectuales norteamericanos, cuya tesis fundamental consistía en el paso obligado de la mayoría de las sociedades tradicionales a sociedades modernas, donde los países del primer mundo tenían un papel central para asegurar este tránsito entre una etapa y otra ${ }^{274}$.

En materia de fuentes, este capítulo se basa en la revisión sistemática de La Patria de Manizales y El Diario de Pereira, con el fin de rastrear información sobre los gobernadores militares en Caldas, concretamente sobre sus intervenciones públicas a través de comunicados o noticias acerca de sus visitas a municipios, reuniones políticas y declaraciones. Además, la prensa local permitió recopilar datos respecto a las acciones de bandoleros en

272 Juan Esteban Ugarriza y Nathalie Pabón Ayala, Militares y guerrillas: La memoria histórica del conflicto armado en Colombia desde los archivos militares, 1958-2016 (Bogotá: Editorial Universidad del Rosario, 2017), 25.

273 Robert Karl, La paz olvidada (Bogotá: Editorial Nomos S.A, 2018), 78-79.

274 Arturo Escobar, La invención del desarrollo trad. por Diana Ochoa. 2. ${ }^{a}$ edición (Popayán: Universidad del Cauca, 2014), 105. 
lo que se refiere a hechos violentos, así como a las denuncias de los campesinos. También, se tomó como fuente primaria la Revista Criminalidad, la cual ofrece la visión oficial de la Policía frente al problema de orden público - durante el periodo de estudio- y un vasto material estadístico con el que apoyan sus análisis y la eficacia de las estrategias implementadas para el mantenimiento del orden.

La revisión de esta documentación y el tema mismo del presente capítulo cobran relevancia pues a la fecha no existen estudios que dediquen su atención a la evaluación de las estrategias de pacificación implementadas entre 1953 y 1965, periodo en el cual se presenta un declive en la ejecución del Plan Lazo y, en particular, en la acción cívico militar. En esta medida, el estudio de los programas de esta última se ubica en la línea de análisis sobre el papel del Ejército en La Violencia, en tanto agentes destinados para el desarrollo de la nación por medio de la ejecución de misiones distintas a las de la defensa; esto es, más enfocadas a reafirmar la presencia del Estado en territorios afectados por los actores armados.

\subsection{Presencia bandoleril y primeros años del Gobierno militar en Caldas}

La situación de "orden público», como fue denominada en principio la problemática de violencia política que vivía el país, podía resumirse en el drama de cinco departamentos, a saber, Tolima, Santander, Antioquia, Caldas y Valle; identificados como los más afectados debido a la creciente cifra de delitos que en ellos tuvieron lugar, con un saldo de miles de víctimas por las acciones perpetradas a manos de distintos actores armados, en particular, por bandoleros. Al respecto, las cifras recopiladas por Paul Oquist pueden ser ilustrativas. Este autor plantea que, de un total de 57 048 muertos, entre 1951-1960, que afectaron en especial los cinco departamentos mencionados, 2606 correspondieron a Caldas. El Tolima fue la jurisdicción que ocupó el primer lugar con 5257 
muertos $^{275}$. En cuanto a esto, la Revista Criminalidad anotaba lo siguiente para el año de 1958:

Las ciudades de Pereira y Armenia, ambas del departamento de Caldas arrojan un total de 2.502 [sic] y 1.757 [sic] delitos respectivamente, superando en forma alarmante a la misma capital del departamento, que solo registra 845 delitos. Si bien es cierto, que esta irregularidad en el aumento de la delincuencia puede tener en parte su explicación en el desplazamiento de grandes masas campesinas del occidente de Caldas y la región del Quindío, por acción de la violencia, no es menos cierto que las cifras denotan un estado de descomposición que merece atención preferencial por parte de las autoridades ${ }^{276}$.

Figura NRo. 22. Mapa de zonas afectadas por

La Violencia 1948-1953.

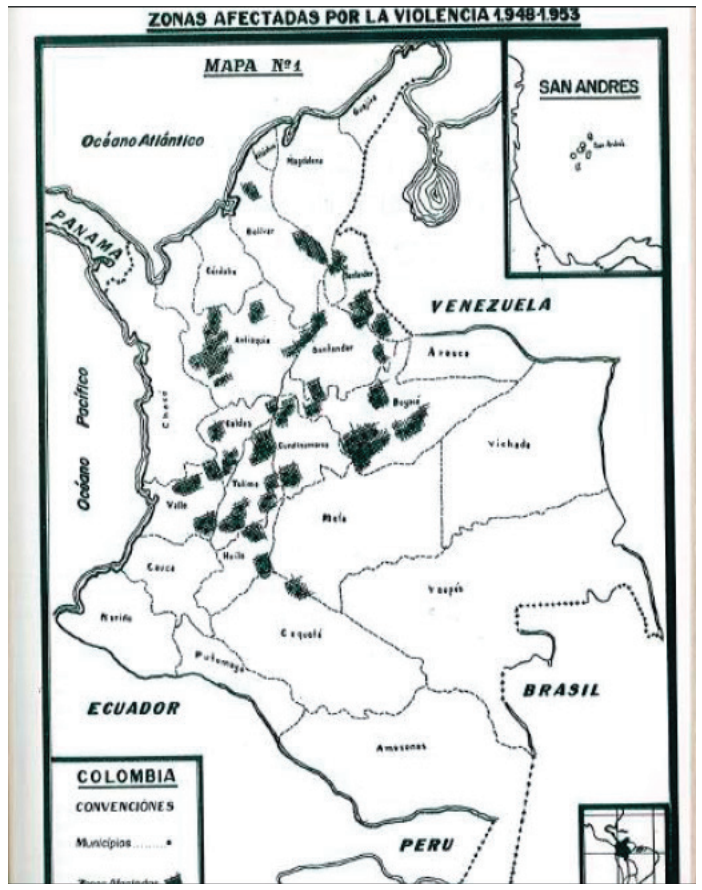

Fuente: Policía Nacional, Revista Criminalidad

(Bogotá: n/a, 1959), 63.

275 Paul Oquist, Violencia, conflicto ...,18.

276 Fuerzas Armadas de Colombia, Estudio criminológico (Bogotá: Ministerio de Guerra, 1958), 9. 
Adicionalmente, la Revista Criminalidad hizo una clasificación de delitos recurrentes para la época en los cuales ubicó, entre otros, los que atentaban contra el comercio, la moral, los bienes materiales, la vida e integridad personal, la soberanía nacional y la seguridad del Estado. En este último se agrupaban la apología del delito, la asociación para delinquir, la asonada, el contrabando de armas, el encubrimiento, el fraude, la fuga de presos, las huelgas, la perturbación de la paz de la nación o delitos contra ella, el porte de armas, la rebelión y la traición. La mayoría de estas infracciones eran cometidas por los bandoleros, así lo decían las Fuerzas Armadas:

... venidos de los departamentos del Valle y Tolima, todos de alta peligrosidad, como Elviro Matilla (Veneno), Jesús Quintero (Venganza) y Noel Parra (Tiro Fijo) que tomaron especialmente las regiones de la cordillera vecina a los municipios de Calarcá y Salento como centro de sus operaciones ${ }^{277}$.

Entre los actos violentos que configuraron este periodo se encuentran asesinatos, amenazas, hurto, atentados, abigeato, extorsiones y otras acciones que eran ejecutadas a nombre propio por parte bandoleros organizados en cuadrillas y motivados por factores de índole económica y política.

La aparición de bandoleros se produjo en medio del desconcierto suscitado entre liberales, conservadores y comunistas armados luego de que la organización campesina e insurgente hubiera sido desarticulada, tanto por las amnistías que ofreció el gobierno de Rojas Pinilla, como las que luego ofreciera el gobierno del presidente Alberto Lleras Camargo en $1958^{278}$.

277 Fuerzas Armadas de Colombia, Estudio criminológico..., 20.

278 Ugarriza y Pabón, Militares y guerrillas..., 57. 
Como se pudo ver anteriormente, los bandoleros eran reconocidos, en la mayoría de los casos, por sus alias ${ }^{279}$ como «Desquite», «Venganza», «Chispas», «La Gata», «Zarpazo», «Cariño», «Paticortico», «Cenizas», «Peligro», entre otros; y por sus acciones que, en principio, fueron vistas como luchas justas y temerarias que llegaron a recibir el apoyo de los pobladores de las regiones ${ }^{280}$.

Luego de las amnistías del año 1953, muchos de los antiguos guerrilleros conservaron sus armas, pero sin tener un vínculo político partidista; razón por la cual empezaron a verse en aquellos territorios en los cuales estaban asentados como una especie de autoridad que, ocasionalmente, maniobraba como justiciera en las disputas contra los poderes económicos locales. En otras ocasiones, tal autoridad actuó de manera vengativa, lo cual generó efectos negativos en cuanto apoyo de la población:

¿Quiénes eran los "bandoleros"? Un ministro estimaba que "el $80 \%$... [eran] adolescentes con edades que oscila[ban] entre los 15 y 20 años". Aunque la estimación podía ser exagerada, era ampliamente aceptada: "los hijos del monte" —esa generación de muchachos del campo que habían quedado huérfanos por el conflicto de los años cuarenta y cincuenta- se habían hecho hombres de muy mala manera ${ }^{281}$.

279 Los Alias han sido objeto de estudio en el país, especialmente por Orlando Villanueva, autor del libro Guerrilleros y bandidos. Alias y apodos de la violencia en Colombia (Bogotá: Fondo de publicaciones de la Universidad Distrital, 2007), y de artículos en revistas especializadas como «Delincuentes: alias y vida cotidiana en Bogotá, 1963», Revista Historia Caribe 6, n. ${ }^{\circ} 18$ (2011): 105-125; «Por sus alias los conoceréis» Edición especial Revista Semana (2005): 66-68; «Los alias, más que una simple chapa» El País (2005): 2-2. Trabajos en los cuales se ha logrado determinar la escogencia de los apodos que, en el caso de aquellos que ocupan este trabajo, dan cuenta del contexto rural del que eran parte los bandoleros, como también de las deficiencias en la organización militar de los mismos.

280 Esto se encuentra relacionado con la idea de «Bandolero» que desarrolla el historiador Eric Hobsbawm en sus textos «Rebeldes primitivos» y «Bandidos» en los que, por primera vez, se adjudicó una teoría y una tipología bandoleril. Entre los elementos que Hobsbawm destaca, se encuentra: «... el bandolerismo es un fenómeno marginal, no sólo [sic] desde el punto de vista de su asentamiento geográfico — regiones aisladas, despobladas e incomunicadas—, sino también desde el punto de vista del volumen de efectivos humanos que normalmente integran las bandas». Sánchez y Meertens, Bandoleros..., 22.

281 Karl, La paz..., 222. 
Figura NRo. 23. "El Montañero" se fugó anoche del cuartel de la policía.

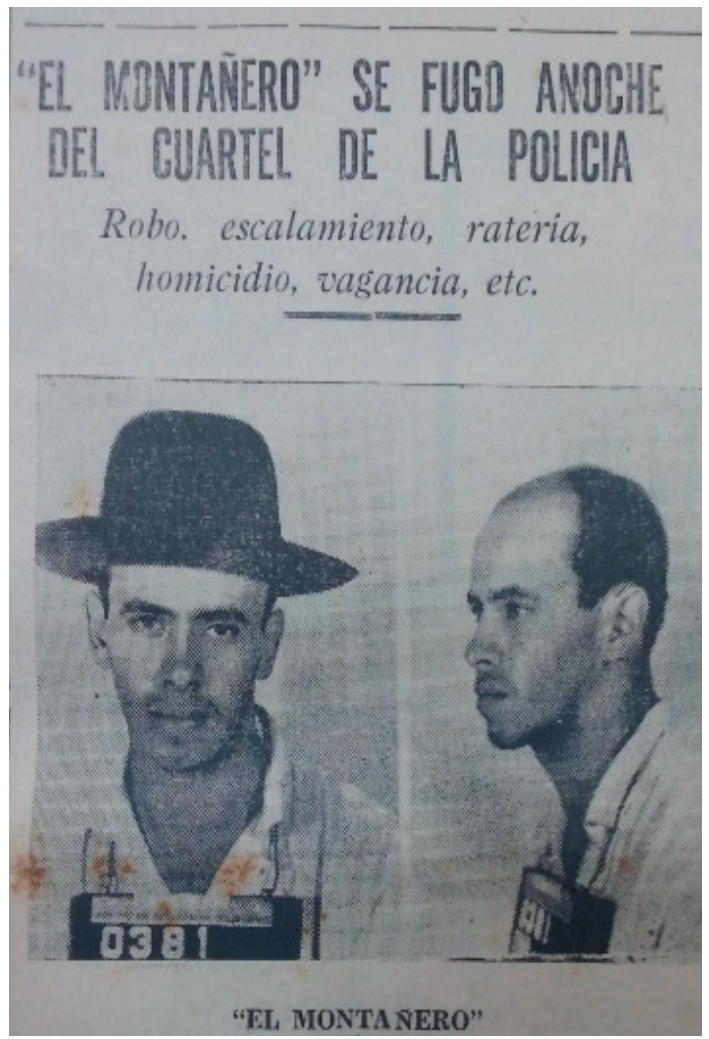

Fuente: El Diario [Pereira], 5 de abril de 1957.

Con la aparición de estos actores hubo un cambio en la práctica de la violencia. Se pasó de una violencia política a una violencia bandoleril cuya principal motivación escapaba de la jurisdicción política ligada al bipartidismo. Sin embargo, estos fueron influidos ideológicamente por las disputas pasadas entre las dos fuerzas políticas tradicionales. Se debe señalar que algunos de ellos sí tenían filiación con el Partido Comunista, aspecto que posteriormente va a determinar el desarrollo del conflicto colombiano $^{282}$.

282 Ugarriza y Pabón, Militares y guerrillas..., 79-134; Ver también: Jacobo Arenas, Diario de la resistencia de Marquetalia (Bogotá: Ediciones Izquierda Viva, 2015), 7-11. 
Alrededor de la procedencia de estos sujetos como de sus cuadrillas, se había establecido que varios de ellos provenían de las antiguas guerrillas liberales, del conservatismo, eran hombres fugados del Ejército $\mathrm{u}$ «... otros que terminaron involucrados por el espíritu de aventura que la situación y el contexto político y social generaba ${ }^{283}$. Cabe señalar que, respecto a este punto en la búsqueda en archivos se encuentra que como sinónimos del adjetivo «bandoleros» se halla el de «antisociales», una palabra la cual da a entender que sus actuaciones violentas los habían distanciado de los intereses sociales y del orden institucional. Situación que abonaba la idea enunciada por los militares de que el país enfrentaba una «descomposición moral». Además, el término antisocial desconocía el tinte político de quienes ejercían la violencia; de forma que el Ejército podía proceder sin ser culpabilizado de atacar a los miembros de algún partido.

Al lado de la violencia bandoleril, también se encontraba la generalización de la violencia bipartidista en los territorios, situación que era explicada por las fuerzas militares debido a la influencia ejercida por actores armados de los departamentos contiguos. Estos decían lo siguiente:

... la mayor intensidad de la violencia la que multiplicó la actividad de las cuadrillas de bandoleros se debió más que todo a la influencia de la violencia reinante en los departamentos de Tolima y Valle. Quedando Caldas en medio de los dos departamentos, en medio de la influencia de las cuadrillas de bandoleros del Tolima, y en tanto que la zona lindante con el departamento del Valle recibió la influencia de los llamados "pájaros". Tan cierto es esto que los municipios de Calarcá, Pijao, Salento y Génova bien pronto se vieron congestionados en sus zonas rurales por los bandoleros. Por su parte los municipios limítrofes con el Departamento [sic] del Valle del Cauca como Balboa, Viterbo, Belalcázar, Santuario,

283 Ugarriza y Pabón, Militares y guerrillas..., 56. 
La Celia y La Virginia sentaron sus reales los "Pájaros" procedentes en su mayor parte de Sevilla, Tuluá, Caicedonia y Cartago ${ }^{284}$.

Ahora bien, pasados dos meses de la instauración del Gobierno militar, la constante denuncia en la prensa sobre las actuaciones de bandoleros propició el nombramiento de militares en la Gobernación de Caldas con el fin de llevar la paz al departamento que había sido denominado como «modelo» de Colombia.

De esta manera, en 1953 inició la administración del coronel Gustavo Sierra Ochoa con una duración de tres años. Este personaje había sido designado por mandato del Gobierno nacional con la tarea inmediata de retornar del sosiego al departamento. El inicio de esta «nueva» etapa en Caldas se abrió paso con un discurso de legitimación del ejercicio político, por parte de los militares, con mensajes recurrentes que buscaban ilustrar la distancia que había entre la acción del poder ejecutivo - en manos del personal castrense- y las prácticas políticas de conservadores y liberales. En la perspectiva del nuevo mandatario regional no cabían «... los intereses feroces del partidismo, las luchas parroquiales, la caza de votos» ${ }^{285}$. En un segundo momento, fueron las obras cívicas y modernizantes emprendidas por Sierra Ochoa lo que le otorgaría una imagen distintiva a su mandato y, en general, al de las Fuerzas Armadas - por lo menos así se quiso mostrar a la opinión pública y la posteridad-.

Llegados a este punto, se hace importante darle una mirada a la estrategia de ACM, cuya comprensión se puede dar a la luz de las doctrinas contrainsurgentes que, en parte, fueron diseñadas por los Estados Unidos luego de la Segunda Guerra Mundial y

284 Fuerzas Armadas de Colombia, Estudio criminológico..., 29. Jhon Jaime Correa, Natalia Agudelo Castañeda y Edwin Mauricio López. «Los gobernadores Militares en Caldas». Corporación Piedramaní, 28 de septiembre de 2018, https://www.slideshare.net/ CorporacinPiedraman/los-gobernadores-militares-de-caldas.

285 Gerardo Jiménez Tobón, Gobernantes de Caldas 1905-1955 (Manizales: Imprenta Departamental de Caldas, 1955), 283. 
estuvieron utilizadas con resultados exitosos -antes que en Colombia - en Corea y Filipinas ${ }^{286}$. De esta manera,

Estados Unidos utilizó el concepto de acción cívica, en Filipinas, cuando se enfrentaron a la tarea de gobernar y modernizar una antigua colonia española, así como enfrentarse a la lucha contra una insurgencia guerrillera. Como un medio para ayudar a poner fin a la guerra de guerrillas, los Estados Unidos llevaron a cabo un programa a gran escala de desarrollo económico y construcción de la nación que consistió en edificación de centros educativos, médicos y de salud, construcción de carreteras, y mejora de la administración gubernamental. Este programa de acción cívica benefició enormemente a la población y ayudó a poner fin a la guerra de guerrillas ${ }^{287}$.

Al lado de esta experiencia, en el caso colombiano fue importante el envío del Batallón Colombia a Corea, expedición en la cual hizo presencia el teniente coronel Alberto Ruiz Novoa, quien sintetizó los cambios más importantes de la Guerra Fría con base en el conflicto coreano. Allí, analizó la importancia de la modernización del Ejército y los cambios tácticos, particularmente, en cuanto al fortalecimiento de la rama de ingenieros y la infiltración guerrillera «... como un aspecto de la guerra total difundida por los comunistas, en la que las reglas convencionales se desdibujan, y [se vuelve importante] el papel que la guerra psicológica» ${ }^{288}$.

286 Aún cabe señalar que el primer ejemplo del empleo del concepto de acción cívica por parte de los Estados Unidos, fuera de la nación, fue en la guerra mexicana estadounidense (1846-1848). En ella el comandante de los Estados Unidos, general Winfield Scott, llevó a cabo programas de acción cívica durante el período anterior a la caída de Chapultepec, en septiembre de 1847, hasta la promulgación del tratado de Guadalupe Hidalgo en febrero de 1848. Aunque este fue un período relativamente corto, el general Scott tomó estudios de atención médica, apoyó a las agencias sociales de la Iglesia y alentó la reapertura de las instituciones educativas. Con la eliminación de las fuerzas de los Estados Unidos de México, los Estados Unidos no emplearían nuevamente el concepto de acción cívica fuera de la nación hasta el cambio de siglo. David Edison Malott, «Military Civic Action in Colombia» (Tesis de máster, Universidad de Florida, 1985), 10.

287 Malott, «Military Civic Action in Colombia»..., 10.

288 Castro Morales, «Modernización contrainsurgente...», 57. Para ampliar el tema alrededor del Ejército en la guerra contra el Perú, ver: Carlos Camacho Arango, El conflicto de Leticia (19321933) y los ejércitos de Perú y Colombia (Bogotá: Universidad Externado de Colombia, 2016). 
La adopción de un programa formal de acción cívico militar en Colombia se produjo oficialmente en el año de 1963 durante la campaña del Gobierno de los Estados Unidos para apoyar en América Latina el establecimiento de este proyecto, con el fin de ayudar en el desarrollo nacional. Esta situación no quiere decir que tal concepto haya sido completamente ajeno o nuevo para el país ${ }^{289}$.

En este sentido, es interesante ver cómo la Octava Brigada ${ }^{290}$ reflexionaba alrededor de las causas fundamentales que llevaron al inicio de La Violencia. Para los militares, además del enfrentamiento partidista, influyeron de manera determinante los siguientes aspectos: a) la expansión de este fenómeno en el territorio colombiano -que anteriormente fue llamado generalización de la violencia-, especialmente en la población campesina quienes «acogieron sin menor duda las tesis y argumentos de los abanderados intelectuales de las luchas partidistas, hasta llegar a la persecución y muerte de sus adversarios»; b) el surgimiento de jefes y capataces de cuadrilla, quienes infundieron el miedo y el terror con lo que lograron adhesión y apoyo moral de personas del campo y moradores de las respectivas regiones donde hicieron presencia; c) el «comunismo internacional», doctrina que habría servido de base a los jefes bandoleros para aumentar los crímenes y el «genocidio» ${ }^{291}$.

\footnotetext{
289 Sobre ello se puede dar cuenta de dos ejemplos: el primero, el final de la Guerra de los Mil Días en enero de 1905, cuando el presidente Rafael Reyes comenzó a emplear a la milicia en proyectos de construcción pública. Y el segundo tiene que ver con el ascenso al poder político del partido liberal en cabeza de López Pumarejo, quien cambiaría la orientación de la misión del Ejército después del conflicto de Leticia con Perú. Este cambio se hizo evidente en 1935 cuando el presidente Alfonso López declaró que la sociedad colombiana no podía permitirse un ejército que no tuviera utilidad social en tiempos de paz.

290 La VIII Brigada es producto de la segregación de la Tercera y Cuarta Brigada, con sede en Cali y Medellín respectivamente. Esta fue creada en septiembre de 1962 por la resolución nro. 3877 del Ministerio de Guerra. Hasta su creación, «... las áreas de Pereira, Armenia y zonas cafeteras de la cordillera central estaban bajo control de la Cuarta Brigada [...]. Las zonas de Sevilla, Caicedonia, Cartago y en general lo que es el Norte del Valle eran controladas por la Tercera Brigada». VIII Brigada, De la violencia..., 30. Su jurisdicción comprende 32 municipios de Caldas, 19 municipios del Valle y 1 municipio de Chocó.
}

291 VIII Brigada, De la violencia ..., 18-20 
De allí se emprendieron labores de pacificación en el territorio caldense con la combinación de estrategias militares y cívicas, por lo que la VIII Brigada decía:

Las Fuerzas Militares comprendieron que la acción-cívica sería la mejor manera con que los hombres de armas podrían contribuir a la pacificación. Civiles y militares cansados ya en la lucha sin razón, emprendieron obras que han venido en tiempo relativamente corto a beneficiar con su acción a gran parte de la población [...] La acción cívica no es otra cosa que la realización de obras que en verdad inciden en el mejoramiento de las condiciones de vida de las gentes más necesitadas e indispensables para subsistir modestamente; dichas obras son: construcción de puestos de salud, construcción de escuelas, construcción de carreteras y construcción de caminos, instalación de plantas eléctricas, construcción y reparación de alcantarillado, construcción de puentes, etc. [sic], es decir realizaciones de carácter permanente de las cuales benefician y contribuyen al bienestar individual y colectivo de la comunidad ${ }^{292}$.

A la realización de las obras cívicas se le sumó el uso de la prensa como un mecanismo de difusión de resultados, tanto en el aspecto cívico (edificación e instalación de obras) como en el militar (bajas, capturas, recompensas a los bandoleros). Este medio, como un instrumento fundamental de la acción cívico-militar, aludía al mismo tiempo a la creación de un ambiente político en el cual se acogieran, por parte de la población, los planes de las Fuerzas Militares con el fin de que fueran estas acciones las que se vieran como prioritarias por parte del Estado. Este proceder, sin duda, contribuía a legitimar el ejercicio político del Ejército.

292 VIII Brigada, De la violencia ..., 85. 
Figura NRo. 24. Acción-cívico militar en Balboa.

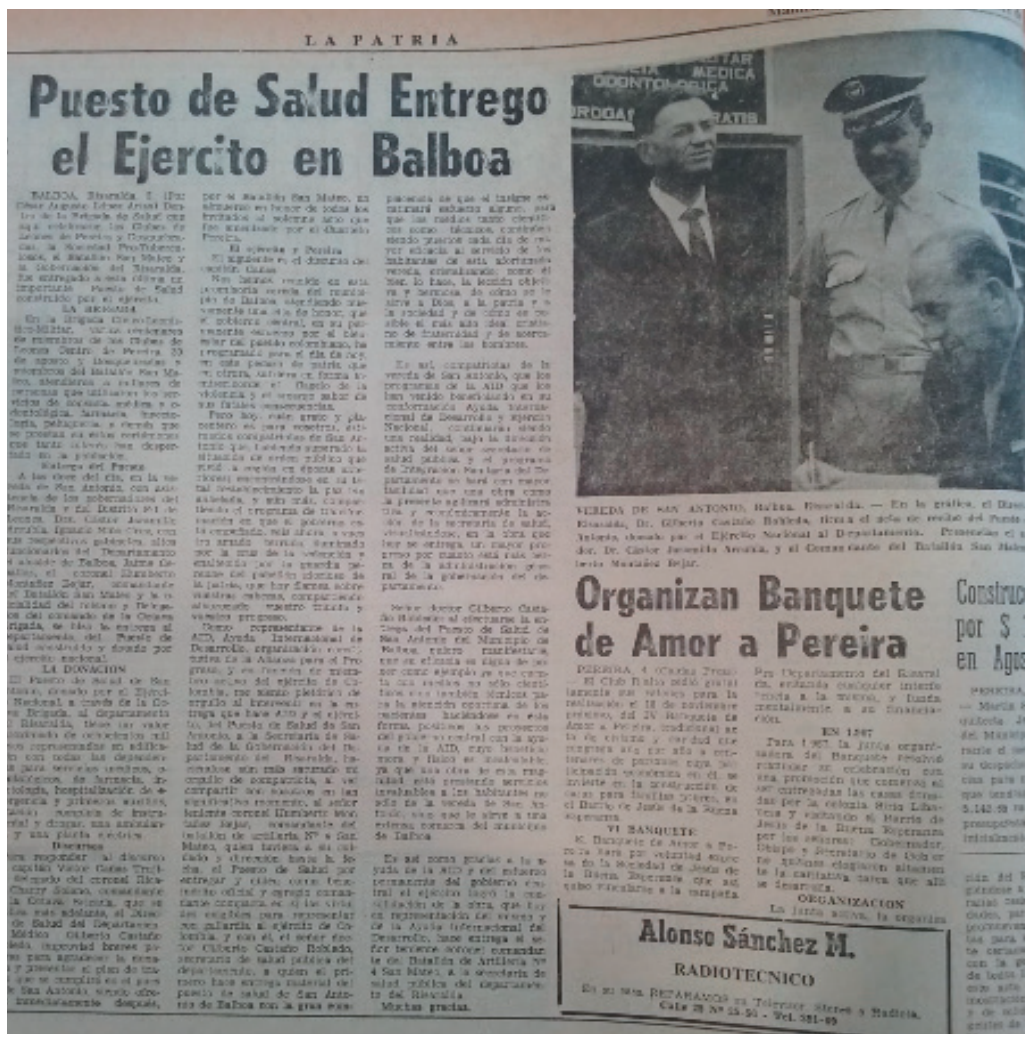

Fuente: La Patria [Manizales], 5 de septiembre de 1976.

Otro aspecto relevante en la definición de lo que significó este tipo de acción para el poder castrense fue la concepción desarrollada por los militares sobre la acción cívico-militar como parte de un cambio en la misma doctrina militar colombiana. Al respecto, el teniente general Alberto Ruiz Novoa ${ }^{293}$ —la voz más autorizada en el tema- ofreció una definición más detallada y elocuente en la Revista de las Fuerzas Militares, al decir:

293 Llegó «... al Ejército de Colombia a los 16 años, cuando en medio de la Guerra [sic] contra el Perú [...] Aunque no combatió, continuó su carrera militar con relativa normalidad hasta que sirvió en Corea, junto con otros oficiales [...] Sirvió [...] como Contralor General de la Nación entre 1953-1957». Castro Morales, «Modernización contrainsurgente...», 61. Fue comandante del Ejército entre 1960 y 1962 y ministro de guerra entre 1962 y 1965. 
La acción cívico-militar tiene el objeto de llevar a vastos sectores de la población la ayuda del gobierno [sic], especialmente en el campo de la asistencia social, aprovechando para ello la organización militar de la nación. Su acción se basa en la idea de emplear los medios militares para llevar a cabo programas de mejoramiento económico y social que despierten en la población beneficiada la confianza y las simpatías hacia el gobierno [sic] y hacia las Fuerzas Militares [...] Además de lograr un efectivo mejoramiento de la situación de la población, la acción cívico-militar acrecienta el apoyo popular hacía el régimen legítimamente constituido y hacia las instituciones armadas, da una nueva muestra de utilidad de éstas [sic] y ayuda a desvirtuar los ataques de quienes ven en los gastos militares solo un drenaje inútil de los dineros públicos y niegan la importancia de la misión de las Fuerzas Militares dentro del Estado ${ }^{294}$.

Cabe resaltar que las obras realizadas durante este periodo coinciden con la necesidad de modernización de las provincias y la manera de coadyuvar al desarrollo industrial del país. Por ello, las gestiones realizadas, en principio por el gobernador Sierra Ochoa y por otros militares, revisten especial relevancia en materia de infraestructura y obras públicas, particularmente, la terminación de carreteras que comunicarían a Manizales - la capital del departamento- con los municipios periféricos como Riosucio y la vía hacía el Líbano (Tolima) con el fin de acortar la distancia con Bogotá. Otro tipo de obras - significativas para la población - adelantadas durante la administración militar fue la construcción de campos deportivos, la reconstrucción de alcantarillados en diversas zonas rurales, el montaje de la segunda unidad de la Hidroeléctrica de Caldas, el aeropuerto La Nubia y otra serie de proyectos diseñados desde el Gobierno nacional alrededor de la educación y la higiene ${ }^{295}$.

294 Alberto Ruiz Novoa «La acción cívica en movimientos insurreccionales», Revista de las Fuerzas Militares, n. ${ }^{\circ} 21$ (1963): 493.

295 Jiménez Tobón, Gobernantes de Caldas ..., 281-282. 


\section{2. «Caldas volverá a ser modelo»: la Gobernación de Gerardo Ayerbe Chaux}

El trámite para darle fin al Gobierno militar del teniente general Rojas Pinilla fue el nombramiento de una Junta Militar de Gobierno. Esta estuvo compuesta por cinco altos oficiales de las Fuerzas Armadas y de la Policía Nacional: Gabriel París, ministro de guerra, quien presidió la Junta; el mayor general Deogracias Fonseca Espinosa, director de la Policía Nacional; el contralmirante Rubén Piedrahita Arango, ministro de obras públicas; el brigadier general Rafael Navas Pardo, comandante del Ejército y el brigadier general Luis Ernesto Ordoñez Castillo, director del Servicio de Inteligencia Colombiano (SIC) ${ }^{296}$.

En el departamento de Caldas ejercía el mando el coronel Gerardo Ayerbe Chaux (1957-1958) ${ }^{297}$, quien al igual que sus antecesores en el cargo, además de su agenda pública como gobernador, prosiguió con la ejecución de acciones cívicomilitares; esta vez bajo la consigna de «Batallas de la Paz». Con este lema se llevaron adelante acciones tendientes a la normalización del orden público, el retorno de la paz y la lucha por el renombre que reclamaba el departamento, el cual se veía opacado por la grave ola de violencia. Como se ha mencionado anteriormente, Caldas y, en particular, la zona del Quindío - en los municipios de Génova, Pijao, La Tebaida, Circasia y Calarcá- fueron territorios altamente afectados por la violencia de bandoleros y pájaros. Para julio y agosto de 1957, se iniciaron los nombramientos de nuevos alcaldes en varios municipios, lo que ayudó a fortalecer las acciones para disminuir los niveles de dicha violencia desde

296 Sandra Patricia Rodríguez Ávila, Memoria y olvido: usos públicos del pasado en Colombia, 1930-1960, (Bogotá: Editorial Universidad del Rosario, 2017), 206.

297 Durante el año de 1957 hubo dos gobernadores militares: los coroneles Daniel Cuervo Araoz (1956-1957) y Gerardo Ayerbe Chaux. El primero salió de la Gobernación acusado de haber dado la orden de disparar a los agentes del SIC contra una manifestación de estudiantes en la Plaza de Bolívar el 10 de mayo de 1954. Respecto al segundo, su motivación más fuerte fue su presunta intención de obtener ventajas personales en su gestión como gobernador. EJE 21, «El rincón de la memoria», 8 de junio de 2009, https://www.eje21.com.co/2009/06/el-rincn-de-lamemoria/. 
la institucionalidad, esta vez no solo por parte de los alcaldes de distintos municipios y el gobernador del departamento, sino también por representantes de la Iglesia y en particular de las élites.

Al seguir esta línea explicativa, el 1 de julio de 1957 iniciaron sus visitas a los departamentos más afectados, los ministros de agricultura, fomento, salud pública y educación: Jorge Mejía Salazar, Joaquín Vallejo, Juan Pablo Llinás y Próspero Carbonell, respectivamente ${ }^{298}$. Estas reuniones políticas, a las cuales asistió el gobernador Ayerbe Chaux en los municipios, tuvieron como propósito un nuevo intento por desarrollar «... un plan conjunto con la Nación [sic]» que, además de la pacificación, tenía en la mira el proceso de «rehabilitación» entendida como el fomento al desarrollo y la modernización.

Vale la pena mencionar que mientras se realizaban aquellas reuniones en las regiones, el discurso de las Fuerzas Militares alrededor del «Binomio» ya referido, el cual era declarado una Tercera Fuerza, había generado la adhesión de la población en varios municipios a través de autodefensas campesinas que contaron con el apoyo táctico y estratégico de dichas fuerzas. Esto se evidenció en distintos hechos relatados en la prensa, en los cuales la población tomaba la justicia por sus manos, al estar agobiada ante el fenómeno del bandolerismo, la violencia de los pájaros y, en general, por las constantes pérdidas económicas que revestía para ellos el robo de la producción agrícola, el ganado y el asesinato de otros campesinos por medio de engaños. La prensa jugó un papel importante como mediador del discurso militar al mostrar como héroes a quienes se defendían de los violentos en esta «Batalla de la Paz». El relato periodístico iba desde la captura hasta la baja de bandoleros, operación bastante útil al cuerpo castrense debido a sus limitaciones para hacer presencia en la totalidad del territorio.

298 La Patria [Manizales], "Cuatro ministros visitaran focos de violencia mañana», 2 de julio de 1957. 
FigurA NRO. 25. «Balboa da la "Batalla de la Paz"».

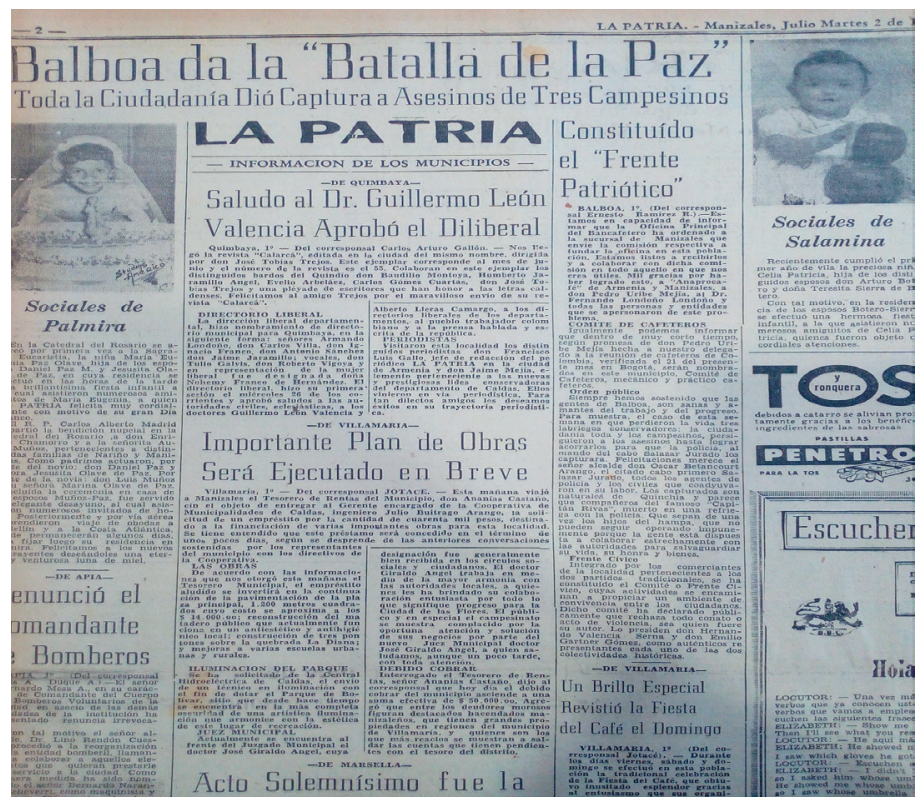

Fuente: La Patria [Manizales], 2 de julio de 1957.

El clima político de este desarrollo sobre La Violencia y su contención era azuzado por lo que se estaba generando en Sitges, lugar donde se reunieron los principales representantes de los partidos políticos -Alberto Lleras Camargo y Laureano Eleuterio Gómez - con el fin de establecer un acercamiento entre las dos colectividades y enarbolar cimientos duraderos para la coexistencia pacífica. Ello daría lugar al pacto político que, entre otras cosas, «restauraría el régimen democrático y exterminaría la violencia del país», con lo cual, sin duda, los militares volverían a la subordinación del poder civil. Entre tanto se había aumentado el pie de fuerza en el Quindío, debido al repunte de hechos violentos. Frente a ello, se daban expresiones como la siguiente:

... como inspector de Génova, Quindío, se me encargó este desempeño como alcalde para el efecto de perseguir de cerca a los que perturbaban la paz y el orden. En desarrollo de este cometido me consagré a las investigaciones pendientes con estos resultados: 
Enviamos a Pereira con acta de detención por delitos de asesinato, robo, etc. [sic], los individuos Mauro A. Álzate Gil, Guillermo Cortés Gutiérrez, Alfonso Ospina Marín, Herber Ospina Franco, José M. Correa, Paulo E. Flor Tabares. Puestos a órdenes de los jueces de instrucción los sujetos Alciden Yacuna, Abel Jurado y Gilberto Agudelo, estos tres hacen parte de la chusma del Tolima, o sean guerrilleros o bandoleros. Se perfeccionan las investigaciones contra Ubaldino Lucuara y Marcos Mendieta [...]. Mis actividades prácticamente las he dedicado a que la impunidad que reinaba antes en ese municipio desaparezca. Entre estos sindicados figuran elementos que nadie osaba perseguir en días pasados; no hoy cuando las autoridades de Génova procedemos sin contemplaciones sin más norte que la tranquilidad del municipio y que los delincuentes vayan a sitios que les señala la justicia como perturbadores de la sociedad ${ }^{299}$.

De la misma forma que el coronel Sierra Ochoa buscó la eliminación de los brotes de violencia en el departamento, Ayerbe Chaux se trazó como objetivo fundamental evitar que Caldas fuera un foco de violencia; además de llevar a cabo la tarea de restauración de la confianza pública en los militares. Para ello, ratificó una pacificación en sentido político y militar, intensificó el desarme y se afianzaron lazos institucionales para generar estructuras en todos los municipios y veredas que pudieran contener la violencia. De allí la importancia de la concreción de alianzas en los municipios del departamento con cada alcalde, corregidor e inspector, todo ello con el fin de ejecutar estrategias conjuntas, las cuales les permitieran avanzar en el propósito común de lograr la paz, y aumentar la confianza de la población en el gobernador. En palabras del entonces secretario de Gobierno, Marino Jaramillo Echeverri se expresaba: «Estamos dispuestos a tomar medidas para restablecer la seguridad social del departamento porque Caldas no será modelo de violencia. Antes de resolver cualquier asunto administrativo, nos dedicaremos al problema de orden público ${ }^{300}$.

299 La Patria [Manizales], «Lucha contra la impunidad adelanta el alcalde de Génova», 26 de julio de 1957.

300 La Patria [Manizales], «Caldas volverá a ser "Modelo”: secretarios de gabinete inspeccionarán los últimos cocos de violencia de esta sección», 16 de julio de 1957. 
Para ello fue indispensable el mantenimiento de las comunicaciones entre los mandatarios municipales y el gobernador por medio de mensajes telegráficos, como también las constantes campañas de desarme y la vigilancia de los miembros de las Fuerzas Armadas de la Policía, en el cumplimiento de sus obligaciones y de las órdenes impartidas desde las mismas alcaldías $^{301}$.

A finales del mes de julio de 1957 apareció en La Patria un comunicado titulado "Creadas Juntas Cívicas para Luchar Contra la Impunidad $[s i c] »^{302}$, por iniciativa del alcalde de Pereira, Bernardo Londoño Villegas. El artículo consignó seis puntos en los cuales se explicitaron los pasos a seguir en la lucha contra La Violencia que, para la fecha, apuntaba como puede observarse en la TABLA NRO. 1.

TABLA NRo. 1. Totales de delitos por secciones del país 1955-1959.

\begin{tabular}{|c|c|c|c|c|c|c|c|c|}
\hline $\mathbf{N}^{\circ}$ & Caldas & 1955 & 1956 & 1957 & 1958 & 1959 & Total & Promedio anual \\
\hline 6 & & 4218 & 4948 & 5982 & 9013 & 9391 & 33552 & 6710 \\
\hline
\end{tabular}

Fuente: Revista Criminalidad (1959).

Además de la creación de una Junta Cívica Central en Pereira, en el primer punto se reglamentó su composición por cuatro personas que debían estar en contacto permanente con el alcalde de la ciudad, quien a su vez sería su presidente. Los integrantes de la Junta fueron Oscar Drews, Luis Sanint, Alberto Ocampo, Arturo Ocampo y José Calle. Estos tendrían como misión colaborar «... activa y vigorosamente en el restablecimiento de la paz y la seguridad en los campos». De allí, el segundo punto trató la creación de una Junta Cívica en cada vereda o zona, la cual tuviera una estructura igual a la anteriormente descrita, pero que - de acuerdo con la localización- debía mantener contacto con los

301 La Patria [Manizales], «Caldas volverá a ser "Modelo"», 16 de julio de 1957.

302 La Patria [Manizales], «Creadas las Juntas Cívicas para luchar contra la impunidad», 26 de julio de 1957. 
inspectores locales o con los colaboradores que correspondieran y, por supuesto, con la Junta Cívica Central. En el tercero se exigía el restablecimiento de todos los retenes en las carreteras por las cuales se pudiera transportar ganado. El cuarto, giraba alrededor de la creación de una bolsa de trabajo para la organización de las Juntas Cívicas en las veredas o zonas rurales. En el penúltimo punto se planeaba la situación en la cual

... para acabar con el miedo entre las gentes de bien e ir eliminando la impunidad, los patronos rurales se [comprometían] a apoyar las juntas cívicas y, de acuerdo a ellas, a denunciar siempre, sin vacilaciones, todos los casos de abigeato y cuatrerismo que descubran, señalando, si los saben, los nombres de los culpables, para que las autoridades apliquen sanciones oportunas ${ }^{303}$.

Finalmente, en el sexto punto se explicaba que el plan tenía un carácter cívico y voluntario, en el cual podrían participar, eventualmente, todos los hacendados y patronos rurales que quisieran acogerlo.

Es necesario recalcar que este tipo de medidas del ejecutivo estaban acompañadas de acciones militares que tenían como objetivo el restablecimiento de la paz por medio, entre otras formas, del exterminio de los bandoleros. Como bien lo dijo en un comunicado a los medios el coronel Ayerbe Chaux:

Contra estos criminales trashumantes que han llegado al departamento de Caldas, no hay más remedio que la acción decidida y eficaz de la autoridad y de todos sus medios coercitivos. También es necesario en esta campaña la presencia moral de toda la ciudadanía y una actitud valerosa de todas las gentes de bien para delatar al delincuente y coadyuvar con las autoridades [...]. Un ambiente de pánico o desconfianza sería el mejor caldo de cultivo para que prosperen los maleantes. Por fortuna la gobernación ha contado con el respaldo unánime del pueblo y de sus auténticos dirigentes, para llevar a feliz término la campaña de pacificación ${ }^{304}$.

303 La Patria [Manizales], «Creadas Juntas Cívicas para luchar contra la impunidad», 26 de julio de 1957.

304 La Patria [Manizales], «Caldas será la gran central de la paz», 27 de julio de 1957. 
A las bajas de bandoleros se debe agregar el papel jugado por otros grupos sociales, quienes colaboraron de cerca con el gobernador de Caldas en el desarrollo de las acciones de corte cívico para el retorno del «orden público» bajo la coordinación de los militares. De esta forma, la integración entre el cuerpo castrense, la Iglesia católica ${ }^{305}$ y las élites del departamento, fueron primordiales en el desarrollo de la acción cívico-militar que, años después, se configuraría como uno de los elementos determinantes para la promulgación y puesta en marcha del Plan Lazo y la conformación de una comisión investigadora de la violencia en 1958. Como parte de los esfuerzos de pacificación sin armas a través de micropactos en las regiones que visitó tal comisión, se atendía la directriz que el nuevo presidente de la República ya en el Frente Nacional-, Alberto Lleras Camargo, enunció en su posesión sobre la conciliación nacional y la pacificación de los espíritus ${ }^{306}$. Al ser uno de sus principales objetivos del régimen bipartidista, se abría paso una idea de la paz ligada a la modernización y a la reducción de la violencia.

Pese a las acciones de las Fuerzas Armadas, Caldas siguió encabezando, por largo tiempo, la lista de los departamentos más violentos de la geografía colombiana (ver FIGURA NRO. 28), por lo menos a partir del criterio del número de muertos producto del accionar bandolero. De allí que entre 1958 y 1959 fuera necesaria la ejecución de otra serie de medidas, las cuales involucraron a la Iglesia católica, a las elites políticas y al Ejército. Estas eran:

$1^{\circ}$ [sic]. Restablecimiento inmediato del principio de autoridad, castigando sin consideración a los delincuentes. $2^{\circ}[$ sic]. Erradicar la impunidad: para extirpar en forma definitiva la violencia y la criminalidad recientes, hay que combatir sin discriminación la impunidad. La paz que se fundamenta sobre la impunidad no

305 Esta, por medio del Boletín Arquidiocesano de Manizales, en el año de 1958, daba cuenta de la importancia que para la Iglesia católica tenía la «obra educativa», en particular la Acción Cultural Popular, donde «Los gravísimos males que aquejan a nuestra patria exigen de todos los sacerdotes y fieles una actitud positiva y un ánimo esforzado para enfrentarse serenamente con los problemas, descubrir y aprovechar las posibilidades existentes de solución, asumiendo la parte de responsabilidad que a cada cual corresponde». «Boletín Arquidiocesano», 398.

306 Karl, La paz olvidada ..., 54. 
podrá ser duradera, porque los cimientos de lo bueno no pueden estar contaminados. La impunidad es una forma de injusticia, de inmoralidad, tratar de estabilizar la sociedad actual sobre bases de impunidad, es un contrasentido, sencillamente, un absurdo. $3^{\circ}$ [sic]. Combatir el comunismo con obras, demostrando la eficacia y superioridad de los sistemas basados en la libertad dentro del orden, sobre los que propugna la dictadura comunista. $4^{\circ}[s i c]$. Apoliticidad y tecnificación en la policía, en el DAS y en el Órgano Judicial. $5^{\circ}[$ sic $]$. Llevar a la conciencia del pueblo colombiano, por todos los medios el convencimiento de que la solución de la violenciaesimposible sin su colaboración. $6^{\circ}[$ sic $]$. Recristianización del pueblo con base en un clero docto y apolítico [...] $11^{\circ}[$ sic $]$. Responsabilidad y cooperación de la prensa hablada y escrita: a) abstenerse de publicar balances de muertos y filiaciones políticas de los mismos, lo cual estimula la paridad en los muertos. b) No ensordecer ni alarmar los ánimos con estruendosos noticieros, que con el ruido nunca se ha conseguido la solución de ningún problema. c) Evitar un criterio cambiante en las apreciaciones lo cual es desmoralizador y desconcertante para la opinión. d) Abstenerse de llenar páginas enteras de corresponsabilidades que no consultan fuentes oficiales o dignas de crédito, con lo cual se evitan seguras ratificaciones ${ }^{307}$.

Entre todas las medidas citadas, saltan a la vista varios elementos que no solo responden a recomendaciones para seguir combatiendo la violencia, sino también al reconocimiento de las fallas al interior de las Fuerzas Militares asociadas a su politización y a la pretensión de reforzar el poder judicial para que fueran condenados los crímenes en proceso. Finalmente, se hace explicito el papel trascendental que cumple la prensa en función de generar un ambiente político equilibrado y de seguir ganando la confianza de la población. Este último elemento llama la atención si se tiene en cuenta que este medio de comunicación estaba incapacitado para formular opiniones que arrojaran responsabilidades o que pudieran alarmar a las gentes.

307 Policía Nacional, Revista Criminalidad (1959): 35. 
FigURA NRO. 26. Muertes violentas en departamentos afectados por el bandolerismo: 1958,1959 y 1960.

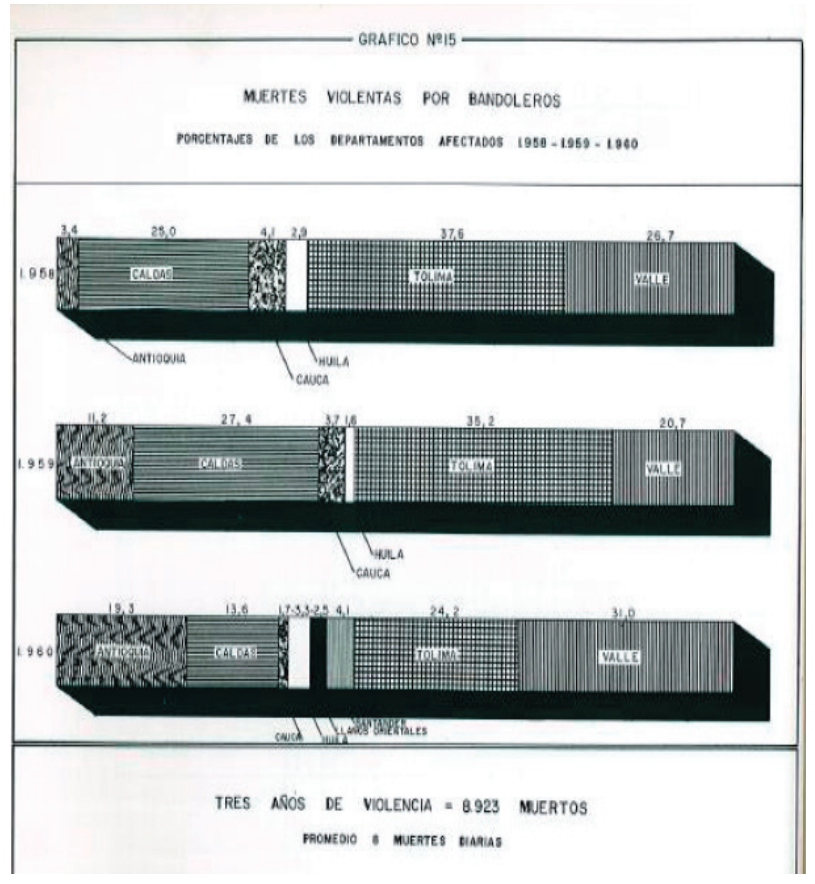

Fuente: Revista Criminalidad, 1960.

\subsection{4: entre el exterminio de la violencia bandoleril y el surgimiento de la guerrilla comunista}

En 1962, el entonces comandante del Ejército, Alberto Ruiz Novoa, apoyó y desarrolló un plan táctico denominado Plan $\mathrm{Lazo}^{308}$, con la ayuda de otros militares — comprometidos con el final de la violencia colombiana- como Álvaro Valencia Tovar, Gabriel Rebeiz y Jaime Fajardo; además de los Estados Unidos, país que ofrecía beneficios al Gobierno colombiano por medio de

308 El general Ruiz apoyó especialmente los hallazgos del Informe Lebret: Estudio sobre las condiciones del desarrollo de Colombia, publicado en el año 1958. Aquel, en las Perspectivas para una reforma profunda, dedicó un apartado a las funciones de los militares en el desarrollo nacional. De allí que Ruiz Novoa fuera un convencido de estas propuestas y respaldara firmemente el inicio y la ejecución del Plan Lazo. 
la Alianza para el Progreso ${ }^{309}$. Esta cooperación internacional se expresó en el envío de un equipo de investigación estadounidense bajo el mando del brigadier general William Yarborough, quien en su visita tuvo como objetivo evaluar la efectividad de las operaciones de contrainsurgencia. La finalidad de esta inspección técnica era determinar los requisitos, cualitativos y cuantitativos, para la formación de efectivos de guerra especiales; evaluar la situación colombiana para integrar la doctrina y las técnicas viables en la instrucción contra la insurgencia y; finalmente, desarrollar las recomendaciones específicas que tuvieran lugar para la mejora en la lucha contrainsurgente en el país ${ }^{310}$.

Entre otras motivaciones están las relaciones entre Colombia y Estados Unidos, las cuales se plantearon en términos de alcanzar la modernización del país, el afianzamiento del modelo económico capitalista y los objetivos ligados a la política anticomunista. Es decir, en los planes de militares y políticos de ambos países se entretejía, al mismo tiempo, el fin la violencia, la contención del comunismo y la posibilidad de abandonar el subdesarrollo ${ }^{311}$.

\section{Con el plan se trazaron cuatro objetivos centrales:}

309 La Alianza para el Progreso fue un programa de ayuda externa propuesto por Estados Unidos para América Latina, con el fin de crear condiciones para el desarrollo y la estabilidad política en el continente durante los años sesenta. «Con este programa Estados Unidos inauguró un tipo de intervención sistemática, a largo plazo y a escala regional, con miras a orientar el cambio social en América Latina e impedir el avance del comunismo en el marco de la Guerra Fría». Diana Marcela Rojas, «La Alianza para el Progreso de Colombia», Revista Análisis Político, n. ${ }^{\circ}$ 70 (2010): 91-124.

310 Malott, «Military Civic Action in Colombia»..., 71.

311 Entre los académicos no existe claridad sobre la denominación exacta de este plan militar. ¿Se llamó Plan Laso o Lazo? «Para las Fuerzas Armadas, el proyecto fue elaborado por la propia institución castrense y se denominó Plan Lazo, dado que se trataba de "enlazar", de llevar a cabo un cerco militar para desactivar las regiones de influencia comunista. Esta postura ha sido defendida con pasión por el general Álvaro Valencia Tovar, uno de los protagonistas de la toma de Marquetalia. Para sus críticos, en especial de izquierda, el proyecto se llamó, por el contrario, Plan Laso (en razón de su denominación en inglés, Latin American Security Operation), debido a que el ataque a Marquetalia se habría inscrito en un proyecto contrarrevolucionario global para toda América Latina agenciado desde Washington». Eduardo Pizarro Leongómez, «Marquetalia el mito fundacional de las Farc», U.N Periódico, 9 de mayo de 2004, http://historico.unperiodico. unal.edu.co/ediciones/57/03.htm. 
1. Reforzar e integrar la estructura de mando de todas las fuerzas que participaran en misiones de orden público, para establecer claramente la responsabilidad militar de todas las operaciones. 2. Crear unidades tácticas más versátiles y sofisticadas capaces de realizar operaciones de guerra no convencionales exitosas. 3 . Expandir las unidades militares de relaciones públicas y guerra psicológica para mejorar las actitudes de los civiles hacia la misión de orden público del ejército [sic]. 4. Empoderar a las fuerzas armadas en tareas destinadas a contribuir al desarrollo económico y al bienestar social de todos los colombianos, especialmente los que están sujetos a la actividad guerrillera de los bandidos ${ }^{312}$.

Frente al modo de proceder, el plan contemplaba una serie de fases. La primera consistió en operaciones de rastreo, localización y hostigamiento de los grupos de bandoleros; la segunda, implementación de programas de inteligencia y contrainteligencia que tenía como finalidad captar todo tipo de información sobre la situación de los bandoleros, lo cual se complementaba con una campaña psicológica para obtener el apoyo de la población; la tercera y cuarta, centradas en las operaciones de localización y exterminio de los grupos ilegales. Finalmente, se debía proceder en la implementación de todos los programas que fueran necesarios para generar un ambiente político, social y económico favorable a la población y adverso a los grupos armados ${ }^{313}$.

Al respecto, vale la pena citar un fragmento de una declaración del coronel Valencia Tovar que dio para La Patria, dos años después de la puesta en marcha del Plan Lazo, cuando ya era presidente Guillermo León Valencia y recién comenzaba a ser construida la figura de «Tiro Fijo» como un enemigo central en la confrontación por la paz:

El fenómeno violento, una vez producido necesita un clima favorable para subsistir, y un carburante para mantenerse en actividad. En consecuencia, un proceso de pacificación requiere

312 Richard Maullin, Soldiers, Guerrillas and Politics in Colombia (Santa Mónica: RAND Corporation, 1971), 73.

313 Ugarriza y Pabón, Militares y guerrillas..., 71-72. 
un doble tratamiento, al cual debe preceder necesariamente un reflexivo estudio de las causas que alteraron el orden normal así: eliminación de las razones que produjeron y alimentan el problema, una vez determinadas con precisión. Y reducción por los medios coercitivos que aparezca indicado emplear en cada caso, de quienes persistan en el hecho violento ${ }^{314}$.

Un elemento medular en la lucha por la paz desde la perspectiva oficial era la labor cívica. De manera reiterada, la comandancia militar resaltaba la importancia de recabar en la acción cívico-militar para acrecentar la confianza en el Ejército y del Estado mismo e impulsar - de paso-un papel distinto para las Fuerzas Militares. Aunque durante la primera mitad de los años sesenta se había logrado cierta tranquilidad, persistía la acción guerrillera con la novedad de disputar el poder político del país debido a la influencia de la Revolución Cubana en 1959, aspecto que sin duda cambiaba el panorama militar y político de La Violencia, y propicia un viraje frente a la contención y al combate frontal contra el nuevo enemigo: el comunismo en su forma más radical. Debido a esto, se decía lo siguiente:

"Se derrumba el tenebroso imperio del bandolerismo", titula La Patria de Manizales, en abril de 1964, cuando cae "Sangrenegra" y efectivamente, entre 1963 y 1965 se desenvuelve el ciclo fatal de decadencia y derrota definitiva del fenómeno bandoleril. Una simple ojeada hacia atrás es suficientemente elocuente: "Chispas" cae en enero de 1963, "Melco" en marzo, el "Capitán Ceniza" en mayo y "Pedro Brincos" en septiembre del mismo año; "Desquite" y "Sangrenegra" en marzo y abril de 1964, seguidos rápidamente por "Tarzán", primero y luego por "Joselito" en septiembre; el turno es para "La Gata" en febrero de 1965 y para Efraín González en junio. La muerte de "Zarpazo", acribillado dos años después, fuera de su zona de apoyo, es hasta cierto punto, una muerte tardía. También el "Estado bandolero" del "Capitán Venganza", cuya temprana muerte en 1961 no había borrado su presencia mítica entre el campesinado, es paulatinamente reincorporado a la soberanía nacional ${ }^{315}$.

314 La Patria [Manizales], «La sociedad ha contribuido a crear el monstruo del bandolerismo, afirma el coronel Valencia T.», 1 de junio de 1964.

315 Sánchez y Meertens, Bandoleros..., 169. 
Este plan mostró resultados en la reducción significativa de los crímenes en las regiones más afectadas, como también en la desaparición física de bandoleros como «Chispas», «Desquite», «Tarzán» $\mathrm{y}$ «Sangrenegra»; este último considerado el bandido más peligroso de Colombia. De acuerdo con la Revista Criminalidad del año de 1964:

De todos los hechos cumplidos en el lapso que comentamos, ninguno que haya contribuido tanto al afianzamiento de la paz pública como el referente a la liquidación de los más antiguos y peligrosos ejecutores de la violencia. La caída de estos cabecillas fue en tal forma decisiva, que por sí sola bastó para que de manera inmediata se desintegraran sus bandas y cesaran o se redujeran notablemente los genocidios en las áreas que les habían servido como escenario de sus depredaciones. De allí precisamente, que en 1964 el número de víctimas hubiera bajado a menos de la mitad, en relación con el anterior, y que extensas zonas del territorio hasta ayer invivibles, como en el caso de Caldas y Antioquia, se encuentren totalmente libres del azote bandolero ${ }^{316}$.

Estos discursos de sosiego y el «éxito» inmediato de la implementación del Plan Lazo en el Tolima, el Valle del Cauca y Caldas - en particular en la zona del Quindío- se facilitó gracias a los avances en la construcción de carreteras y caminos que favorecían la movilidad del Ejército, aunque aún era necesaria la acción tendiente a lograr la confianza de la población. A ello se suma el accionar de algunas autodefensas campesinas como las lideradas por Ciro Castaño Trujillo y Manuel Marulanda ${ }^{317}$, quienes desde finales de los años cincuenta habían ganado cierto apoyo de la gente y logrado acumular algunas armas con el fin de resistir, «... antes de verse obligados a desplazarse a nuevos territorios dada la ofensiva militar en su contra desatada en $1964 »^{318}$.

316 Policía Nacional, «Introducción», Revista Criminalidad, n. 7, 1964: 3.

317 Su nombre real era Pedro Antonio Marín. Para ampliar información sobre este personaje ver: Arturo Alape, Las muertes de Tirofijo (Bogotá: Ediciones Abejón Mono, 1972); Las vidas de Pedro Antonio Marín Vélez Tirofijo (Bogotá: Editorial Planeta, 1989); Tirofijo: Los sueños y las montañas 1964-1984 (Bogotá: Editorial Planeta, 2002).

318 Ugarriza y Pabón, Guerrillas y militares..., 77. 
En 1964 se desarrolló la famosa «Operación Marquetalia» que el Ejército denominó "Operación Gama Soberanía». Esta tuvo un despliegue militar con el que se pretendió acabar con las «Repúblicas independientes», nombre acuñado por el senador Álvaro Gómez Hurtado, quien en una intervención en el Senado señaló que había grupos de campesinos armados en dieciséis puntos geográficos, los cuales escapaban al control del Estado. Ante ello, el Gobierno de Guillermo León Valencia decidió recuperar los territorios por la fuerza, lo que generó resultados inesperados y puso en evidencia sus problemas de gobernabilidad. El bombardeo mencionado configuró años más tarde el mito fundacional de las Fuerzas Armadas Revolucionarias de Colombia-Ejército del Pueblo (FARC-EP). Igualmente, inició la transformación en el entendimiento de La Violencia, toda vez que se presentó un cambio en la forma de nombrar a los actores contra los cuales se lucharía, de bandoleros a guerrilleros. A partir de allí se abriría una nueva época en el repertorio de acciones violentas, todo esto en un momento de retorno al gobierno civil. De esta manera, el año de 1964 ha sido visto por otros estudiosos del tema, como un referente obligado para la compresión del conflicto armado en Colombia y su expresión más reciente, dado que expresan:

Es también, un acontecimiento en el que se evidencia el final de un ciclo y el comienzo de otro: el final de un ciclo de violencia, 19461953, que encuentra un fin aparente en el proceso de pacificación propuesto por el gobierno del general Gustavo Rojas Pinilla en 1953 — siendo Marquetalia, en cierto modo, resultado de esa primera violencia y etapa de pacificación - y el comienzo de la violencia que se vivió durante el periodo de 1958-1964 ${ }^{319}$.

Dentro de estos cambios, en el fenómeno de La Violencia vivido en el país, se encuentra la sofisticación táctica y estratégica

319 Lucia Estévez Pedraza, «Marquetalia: El mito fundacional de las Farc y la construcción del enemigo a través de la prensa». En: La Prensa: un actor sempiterno. De la Primera Guerra Mundial a la Posmodernidad, coord. por Rosa María Vallez Ruíz, Rosa María González y Patricia Vega Jiménez (México: Universidad Autónoma del Estado de Hidalgo, 2014), 229. 
de las guerrillas con la puesta en marcha de una guerra de guerrillas móvil que tenía como finalidad el impulso de la revolución comunista. Todo ello, en principio, rebasó la capacidad del Ejército en la medida que este seguía utilizando estrategias propias de la guerra convencional ${ }^{320}$. Esta debilidad por parte del Ejército fue compensada con la acción cívico-militar que cumplió un papel determinante en la contención del accionar insurgente. Según el mismo Manuel Marulanda Vélez en el Diario de la Resistencia de Marquetalia:

Las agencias radiales y la gran prensa truenan todos los días pidiendo una batida a determinado grupo de "bandoleros" y con especialidad a la materialización del Plan LASO. Un aspecto de la guerra psicológica y de ablandamiento y corrupción de la conciencia de la gente vacilante, es el ofrecimiento de grandes sumas de dinero por el asesinato de los dirigentes más destacados del movimiento. Se lanzan infames calumnias todos los días por la prensa y la radio, así como por carteles y hojas volantes, acusando a los dirigentes de todos los delitos, precisamente cometidos por las fuerzas armadas oficiales [...]. Distribución de centenares de miles de hojas volantes y carteles dirigidos a la población, solicitando respaldo para la "acción cívico-militar" mostrando [...] fotografías de los soldados suboficiales y altos oficiales ayudando al campesino en sus quehaceres domésticos, librándolos de los peligros y acechanzas de los bandoleros, prometiendo paz, tierra, escuelas carreteras y ayudas en general ${ }^{321}$.

A propósito de la cita, Marulanda planteó, en un capítulo del Diario de la Resistencia de Marquetalia, la separación inmediata con el adjetivo de bandolerismo, toda vez que esta clasificación rebajaba la estatura de cuadros políticos y militares de los guerrilleros. Como se sabe, al interior de su organización tuvo un papel importante la formación de estos en función del desarrollo 
de una guerrilla comunista y de la toma del poder ${ }^{322}$. Otra característica de ruptura, representada por las nuevas guerrillas, fue la filiación abierta al Partido Comunista Colombiano. De esta manera, se afirmó como su principal enemigo el imperialismo norteamericano, situación que hacía parte de la polaridad reinante en el mundo entre los Estados Unidos y la Unión Soviética. Por ello decían:

Los enemigos que combatimos aquí en estas selvas no son más que la tropilla al mando de los imperialistas. Además, esa tropilla está compuesta por otros hombres que no vienen aquí a enfrentarse con nosotros. Los altos mandos militares, los banqueros, los grandes industriales y comerciantes, los grandes latifundistas, los políticos de alto coturno [...] mandan a sus tropas engañadas [y para ello] se apoyan en la fuerza del imperialismo. Si no fuera por la ayuda norteamericana, pronto daríamos buena cuenta de la oligarquía ${ }^{323}$.

Ahora bien, estos hechos que tuvieron lugar en Marquetalia desde el mes de junio de 1964 fueron seguidos por la prensa nacional y local. Esta construyó un relato en el cual se planteaba un nuevo enemigo, «Tiro Fijo». Este nuevo personaje fue concebido como representante único de los rezagos de violencia de los años cincuenta en el país, a aquel le adjudicaron una imagen de monstruo, de enemigo de la patria, de bandolero e «inmoral»; incluso antes de haber sido publicado su rostro. Una vez más, la prensa jugó un papel determinante en la puesta en marcha de la acción cívico-militar, esta vez alrededor del exterminio de las zonas llamadas «Repúblicas Independientes», en particular de Marquetalia $^{324}$.

322 Aunque el tema de estudio no es la historia de las Fuerzas Armadas Revolucionarias de Colombia (FARC-EP), es necesario mencionar que su proceso de conformación fue largo al iniciar la ruptura con el Partido Liberal y su posterior adscripción al Partido Comunista; y al proseguir con el perfeccionamiento de la táctica y estrategia guerrillera, el apoyo del comunismo internacional, entre otros aspectos que no han sido estudiados con suficiencia en el país.

323 Arenas, Diario de la resistencia ...,45.

324 Marquetalia es un pequeño territorio del corregimiento de la Gaitanía, municipio de Planadas en el departamento del Tolima en Colombia. Es una zona situada sobre la Cordillera Central y entre las sierras de Atá e Iquira. Allí se levanta una de las mayores alturas geográficas de Colombia: el Nevado del Huila con 5750 metros de altitud. Arenas, Diario de la resistencia... 
En los años subsiguientes a la operación en esta zona del país, según Guillermo León Valencia, se logró dar de baja a veinte cuadrillas de bandoleros de las veintinueve existentes en el momento, con un número importante de capturados. Por su parte, los guerrilleros se dedicaron a la expansión del proyecto político, lo cual representó para el departamento de Caldas la presencia de Ciro Trujillo ${ }^{325}$ en el Quindío, al tiempo que fue designado como comandante de la Octava Brigada el coronel Armando Vanegas Maldonado - quien posteriormente fue gobernador de Caldas-. Dicha operación se extendió en el tiempo hasta el año de 1968, con numerosos combates y en distintos lugares de la geografía nacional en los cuales, finalmente, la guerrilla de las Farc logró resistir, mantenerse y modificar sus tácticas de ataque. En suma, durante la década de los años sesenta, el fenómeno de la violencia siguió teniendo lugar en el país, pero esta vez bajo la forma de la guerra insurgente con el fortalecimiento de los nuevos actores: guerrillas y Ejército.

\section{Conclusiones}

Pese a los esfuerzos por parte del teniente-general Alberto Ruiz Novoa, la acción cívico-militar tuvo un desarrollo desigual y con poca coordinación a lo largo y ancho del país. Las obras públicas que se desarrollaron no estaban necesariamente conectadas con los requerimientos de las regiones, a lo cual se suma que la presencia del Ejército, en las diferentes zonas de conflicto, se encontraba ligada a la duración de las labores de construcción de las obras y no a un plan que se extendiera en el tiempo. Estas acciones no tendían a la generación de procesos de democratización, se trataron realmente fue de la disputa del monopolio estatal de la violencia, el cual se veía en vilo con la existencia de guerrilleros en las distintas regiones. Adicionalmente, la salida de Ruiz Novoa

325 Ciro Trujillo fue un campesino liberal nacido en Calarcá, Quindío. Este se adhirió a las guerrillas liberales del sur del Tolima como reacción a la persecución conservadora. Tuvo presencia en la región del Pato (1963) y en Riochiquito, noreste del Cauca, en un movimiento agrario hasta la ofensiva militar en 1965. Posterior a ello se incorpora a las FARC. Ver Ciro Trujillo, Ciro: Páginas de su vida (Bogotá: Ediciones Izquierda Viva, 2015). 
del Ministerio de Guerra en el año de 1965 —durante el Gobierno de Guillermo León Valencia- hizo que la ejecución del Plan Lazo perdiera el ritmo y el curso llevado hasta la fecha.

A modo de evaluación de la puesta en marcha de la acción cívica y de las estrategias de pacificación, se puede decir que uno de los logros más importantes del Plan Lazo en la región caldense fue la activación de la Octava Brigada; específicamente, la operación de unidades de infantería, artillería, ingenieros, lanceros (fuerzas tipo guardabosques), inteligencia y guerra psicológica - «que tuvo como finalidad la separación de la población del guerrillero, por medio de técnicas de propaganda en la que se realzaban las debilidades y faltas morales de los insurrectos armados» ${ }^{326}$ Además, las cuadrillas de bandidos fueron penetradas por infiltrados militares particularmente entrenados para obtener información, reducir el número de ataques y, finalmente, conseguir su desaparición.

Alrededor de las obras públicas, con el empleo de un batallón de ingenieros - en la región caldense: el Batallón Cisneros-, para el año 1963, «... se habían reparado deterioros en una longitud total de 600 millas en vías de Santander, Caldas, Valle y Boyacá», lo cual contó con el apoyo económico de Estados Unidos a través de la Agencia para el Desarrollo Internacional (AID) ${ }^{327}$. También realizaron los siguientes trabajos: la compañía «A» inició trabajos de construcción de la carretera en el sector de Calarcá, La Rochela, Quebradanegra, edificación del puesto de salud de Quebradanegra. La compañía «B» desarrolló la construcción de cinco kilómetros de carretera en el eje La María-Riveralta-Miravalles, afirmado de seis kilómetros de carretera en el eje Pueblo Tapado-La María entre los departamentos de Caldas y Valle, y la construcción del Estadio de Montenegro ${ }^{328}$.

326 Ortiz, Estado y subversión..., 282.

327 Russell Wilcox Ramsey, Guerrilleros y soldados (Bogotá: Ediciones Tercer Mundo, 1981), 312.

328 VIII Brigada, De la violencia..., 93. 
Por su parte, las acciones dedicadas a la educación fueron, de acuerdo con la Octava Brigada, uno de los aspectos más importantes de la acción cívica debido a que, como ellos lo expresaban, «... la falta de educación fue un factor decisivo para que los bandoleros se aprovecharan de las gentes campesinas, obteniendo como resultado su adhesión y apoyo a sus criminales empeños ${ }^{329}$. En este sentido, destacan la alfabetización realizada con los conscriptos que llegaban a prestar su servicio militar; las escuelas radiofónicas; la construcción de escuelas - que para el año 1965 se habían entregado ocho-; y el desarrollo de cursos de «cívica» para jóvenes entre los trece y los dieciséis años, en los cuales se inculcaba «amor por los símbolos patrios» por medio de materias como historia patria, religión, higiene, primeros auxilios, nutrición, deportes y canto. Cabe señalar que para la selección de un joven fuera en estos cursos, este debía cumplir una serie de requisitos entre los que se encuentran:

Pertenecer a familias necesitadas de todos los municipios de la jurisdicción de la Unidad Operativa, presencia de cupos a los jóvenes oriundos de las zonas más afectadas por la violencia o que se encontraran en zonas de consolidación de la paz, debía contar con la aprobación de los padres o tutores, y los jóvenes seleccionados no debían registrar antecedentes policivos ${ }^{330}$.

A continuación, en la Figura NRO. 27, se da cuenta del número de acciones cívico militares llevadas a cabo en el país entre 1962 y 1969, como parte de la tarea emprendida para ganar la adhesión de la población que en otro momento encubría a las cuadrillas. 
Figura NRO. 27. Programa de acciones cívico- militares logradas (1962-1969).

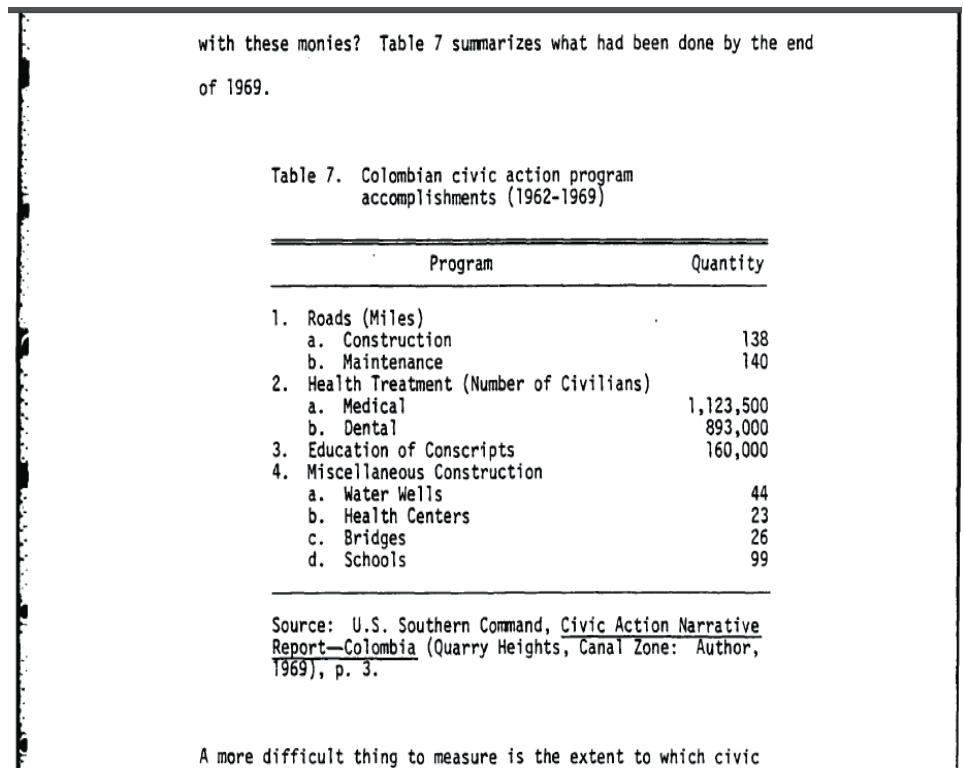

Fuente: Malott, «Military Civic Action in Colombia...», 99.

Al lado de estas acciones, otros elementos que contribuyeron a la pacificación fueron los patrullajes permanentes; las campañas psicológicas adelantadas en lugares considerados como focos bandoleros; la colaboración de la población civil; el pago de recompensas en dinero a quienes dieran información sobre el personal buscado por la justicia - lo que reducía la complicidad generada por temor o simpatía-; y la estrecha cooperación entre gobernadores, alcaldes e inspectores de policía. Al respecto, la Revista Criminalidad ofrece dos mapas comparativos, para dar cuenta de la reducción de la violencia en el país entre 1962 y 1965 y de los cambios obtenidos con la aplicación del Plan Lazo. El mapa número uno (ver FIgURA NRO. 28) muestra la localización de la violencia para el año 1962, momento en el cual se inició la ejecución del plan mencionado. En ese momento, el departamento de Caldas estuvo bajo el flagelo de la violencia; especialmente, en 
los municipios de occidente donde se presentaban entre 51 y 100 muertes a manos de los bandoleros. El mapa número dos (ver FIGURA NRO. 29) muestra el resultado de la acción ejercida por la pacificación, en el cual -claramente- se ve una reducción respecto a la presencia de la violencia en el territorio colombiano y en el que, de manera particular, Caldas aparece sin ningún brote de esta y se muestra una sola convención referida a los «municipios donde hubo entre 10 y 50 muertes por acción de bandoleros». 
FIGURA NRO. 28. Localización de la violencia en 1962.

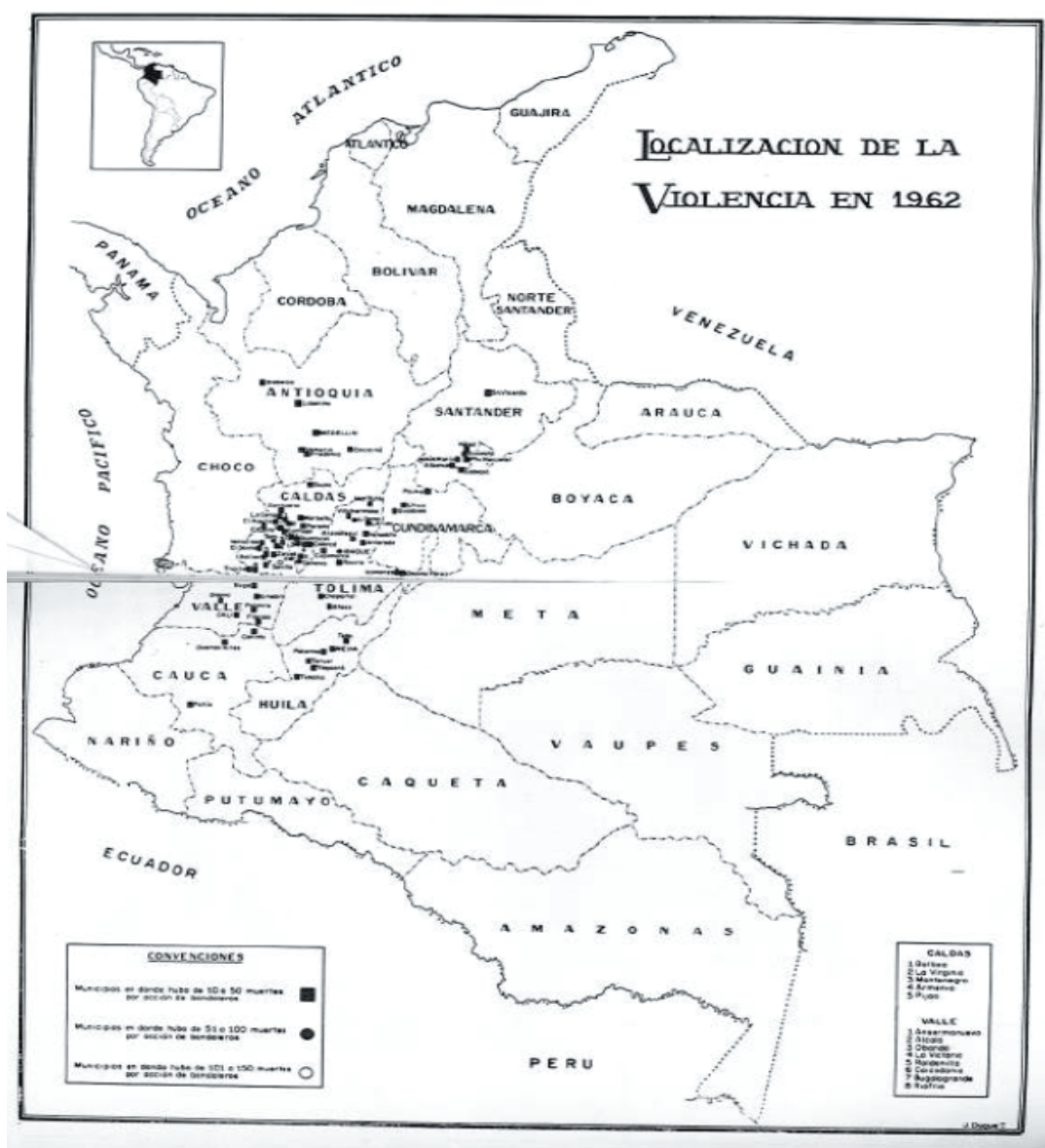

Fuente: Revista Estadística de Criminalidad, n. ${ }^{\circ} 8$ (1965): 24. 
FIGURA NRO. 29. Localización de la violencia en 1965.

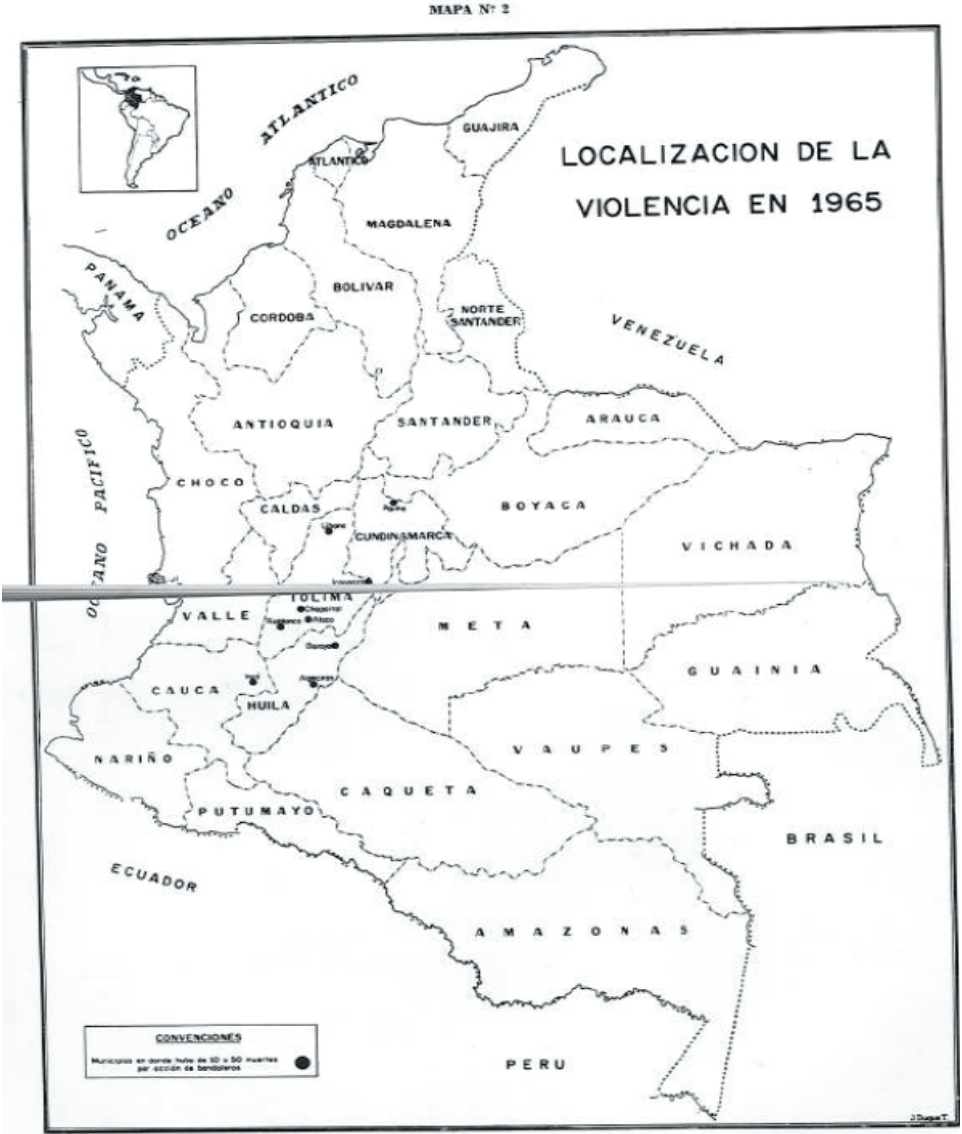

Fuente: Revista Estadística de Criminalidad, n. ${ }^{\circ} 8$ (1965): 25. 



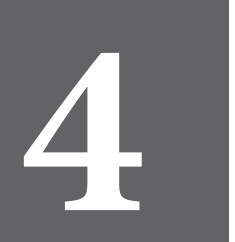

CAPÍTULO CUATRO 



\title{
Bandidos y campesinos. La Banda del Negro Cadena en Belalcázar, Caldas (1958)
}

\author{
Jhon Jaime Correa ${ }^{331^{*}}$ \\ Edwin Mauricio López García ${ }^{332^{* *}}$
}

El presente capítulo analiza a profundidad un sumario judicial — consultado en el Archivo Judicial del municipio de Anserma- por el delito de «Asociación para delinquir» en contra de trece campesinos de Belalcázar (Caldas) en 1958. Esto con el propósito de demostrar, a nivel local, las repercusiones que tenía

$331^{*}$ Doctor en Ciencias de la Educación de RUDECOLOMBIA, Magíster en Ciencia Política de la Universidad de Antioquia e Historiador de la Universidad Nacional de Colombia Sede Medellín. Profesor Titular de la Universidad Tecnológica de Pereira. Autor, entre otros libros, de: Civismo y educación en Pereira y Manizales (1925-1950) (2015) y Tinta Roja. Prensa política y educación en la República Liberal (1930-1946) (2016).

$332^{* *}$ Licenciado en Etnoeducación y Desarrollo Comunitario, y estudiante de la Maestría en Historia de la Universidad Tecnológica de Pereira. Coautor del libro 50/60 Una historia compartida (2016). Ha publicado artículos en revistas especializadas sobre clientelismo durante el Frente Nacional y el proceso de creación del departamento de Risaralda. 
la vinculación a alguno de los partidos políticos para acceder a laborar en una finca de la región. Así, a través de este caso se abre una puerta para echar un vistazo al pasado, observar algunas vivencias de La Violencia y poder rastrear la simultaneidad de las labores agrícolas y armadas de los personajes de la sociedad rural del Viejo Caldas, las cuales demuestran la conformación de un grupo embrionario de autodefensa con jornaleros foráneos de este municipio, quienes fueron contratados en periodo de cosecha por un terrateniente liberal y cuyas actividades de vigilancia, junto con el mayordomo de la hacienda, dieron lugar a la propagación del rumor sobre la presencia de un reconocido bandolero en dicha finca.

Luego, durante el desarrollo del litigio ante un juez militar en la ciudad de Pereira, la justificación de las labores de autodefensa fue argumentada como consecuencia de las continuas amenazas y robos en contra de la hacienda, además de la casi inexistencia de la defensa del derecho a la propiedad del dueño por parte de las Fuerzas Armadas y la justicia a nivel local. La defensa de los jornaleros explicó que las denuncias realizadas por un vecino del municipio y una familia de agregados de la hacienda obedecieron a los intereses del primero, quien supuestamente era un "pájaro» del municipio, el cual quería apropiarse de la finca y había manipulado a los agregados para conseguir dicho fin. Esto devela los móviles económicos de la segunda fase de La Violencia en Caldas ocurrida entre 1954 y 1958, los cuales también son señalados en otros estudios.

En este sentido se demuestra, desde acontecimientos cotidianos, la importancia que jugaba todavía la adscripción partidista en las relaciones económicas de producción a los inicios del Frente Nacional, pues la escogencia y selección de la mano de obra en sus diferentes modalidades, ya fuesen jornaleros, aparceros o agregados, dependía de la confirmación de la pertenencia de los trabajadores a uno de los dos partidos tradicionales, lo cual llevaba 
a que estos campesinos se involucraran en juegos de identidades partidistas a través de elecciones racionales para acceder a un trabajo y obtener su sustento económico.

Se destaca así que tanto las experiencias de pacificación de la Dictadura con sus énfasis en los operativos militares, combinados con las acciones cívico-militares; como el pacto consociacionalista del Frente Nacional hecho por lo alto para la distribución paritaria de la burocracia nacional; no terminaron por completo la violencia partidista a nivel local y demostraron, al mismo tiempo, la precariedad y la arbitrariedad de la presencia estatal en el territorio. Además, como resultado se demuestra la autonomía conquistada por los militares en el tratamiento del orden público al ser estos los encargados, en primera instancia, del proceso judicial que concluyó cuando el Tribunal Superior de Manizales cerró la investigación en 1964, al no encontrar elementos que confirmaran la realización del delito sindicado.

\subsection{Una mirada cultural a La Violencia}

En 1963, Eric Hobsbawm caracterizó el periodo de La Violencia como «... la mayor movilización armada de campesinos ([...] [fuera] como guerrilleros, bandoleros o grupos de autodefensa) en la historia reciente del hemisferio occidental con la posible excepción de determinados periodos de la Revolución mexicana ${ }^{333}$. Por ello, es importante hacer explícito el interés de indagar las vivencias de esa sociedad rural y la manera en que sus campesinos experimentaron el sectarismo político de la época, de forma que, se pueda reconstruir una interpretación más compleja y realista de la racionalidad de estos actores, además de evaluar el tipo de relaciones sociales de producción económica de la sociedad campesina del país a mediados del siglo xx para observar si la violencia política de dicho periodo fue llevada a cabo solo por los campesinos azuzados por los líderes políticos ${ }^{334}$. Sendero que

333 Eric Hobsbawm, «La anatomía de La Violencia en Colombia». En Eric Hobsbawm sobre América Latina ;Viva la revolución!, ed. por Leslie Bethell (Bogotá: Crítica, 2018), 84-85.

334 Mónica Zuleta, «La Violencia en Colombia: avatares de la construcción de un objeto de estudio», Nómadas (Col), n. ${ }^{\circ} 25$ (2006): 57. 
la historiografía nacional ha explorado desde hace varios años de manera disímil y en la que se inscribe este ejercicio a escala local.

Una de las temáticas más evaluadas dentro de la historiografía de La Violencia y que se aproxima a la cotidianidad del enfrentamiento bipartidista, ha sido la del bandolerismo. A partir del estudio de Sánchez y Meertens se han desarrollado trabajos que analizan las características, formas de organización y compenetración con la población civil; e incluso, con las mismas autoridades del Ejército y la policía. En este trabajo sale a relucir la evolución de las relaciones de los bandoleros con el poder central y demás actores sociales como gamonales, hacendados y campesinos que, hacia mediados de los años sesenta, llevaron al aislamiento y a la derrota de estas cuadrillas ${ }^{335}$. Con base en los estudios de Eric Hobsbawm y su definición del bandolero social como «... aquel o aquellos campesinos fuera de la ley, a los que el señor feudal y el estado consideran criminales, pero que permanecen dentro de la sociedad campesina y son considerados por sus gentes como héroes, paladines, vengadores, y luchadores ${ }^{336}$ que además provienen de sociedades arcaicas o primitivas ${ }^{337}$; Sánchez y Meertens definen un nuevo tipo de bandolerismo, el cual denominan político debido a su dependencia total o parcial a la estructura dominante de poder como los gamonales y los partidos políticos en aras de legitimar el orden establecido ${ }^{338}$.

La regionalización de dicho fenómeno, en la obra de estos últimos autores mencionados, fue profundizada en textos como Estado y subversión en Colombia de Carlos Miguel Ortiz. Por ejemplo, en el capítulo dedicado a las cuadrillas liberales, demostró cómo en el Quindío estos grupos armados sirvieron de defensa a los liberales en una suerte de venganza sectaria para robustecer los lazos en las veredas con la comunidad rural ante el accionar de aplanchadores, policías de tendencia conservadora y pájaros,

335 Sánchez y Meertens, Bandoleros..., 15.

336 Eric Hobsbawm, Bandidos (Barcelona: Crítica, 2001), 33.

337 Eric Hobsbawm, Rebeldes primitivos (Barcelona: Ariel, 1983), 12-13.

338 Sánchez y Meertens, Bandoleros..., 26. 
quienes arremetieron en las zonas liberales de dicha región. De este modo, en muchos casos jugaron un papel primordial en la conformación de las cuadrillas y en la ejecución de asesinatos (homicidios con alevosía); cosecheros flotantes; personajes de extracción campesina, pero sin perspectivas de seguridad ni ascenso en el campo; habitantes rurales sin tierra ni residencia fija y desarraigados de sus familias ${ }^{339}$. En el caso del Valle del Cauca, hacia finales de los años cincuenta, también se dio un proceso de retaliación liberal tras el proceso de conservatización durante las presidencias de Ospina, Gómez y Rojas Pinilla, comandado por León María Lozano, alias «El Cóndor» ${ }^{340}$. La organización de las cuadrillas liberales en el norte del Valle que tuvieron el apoyo de las del Quindío y el Tolima estuvieron conformadas por grupos pequeños de refugiados, remontados y perseguidos, campesinos y habitantes de las poblaciones cordilleranas, los cuales fueron instruidos militarmente y apoyados por los directorios políticos, los jefes locales, los finqueros, los hacendados y los comerciantes ${ }^{341}$.

Algunos estudios sobre el bandolerismo para otras zonas del país se han enfocado en poner en entredicho la categoría de «bandolero social» desarrollada por Hobsbawm, y demarcar ciertas divergencias respecto a la aparición de estos actores sociales. A manera de ejemplo, en el caso del Palomo Aguirre en el Tolima se muestra el camino inverso de su conversión en bandolero, de forma que al haber iniciado en un movimiento revolucionario, pasó después a ser líder de una cuadrilla, para terminar siendo un ladrón de ganado ${ }^{342}$. En la misma dirección, se puede mencionar un estudio para la zona del Bajo Cauca, Magdalena Medio y Nordeste Antioqueño entre 1953 y 1958 —elaborado por Diana Henao-, en donde se analiza la fuerte presencia de cuadrillas en dicha región geográfica y se caracterizan como un «bandolerismo

339 Ortiz, Estado y subversión..., 209-260.

340 Delgado Madroñero, El Bandolerismo..., 91.

341 Darío Betancourt, «Las cuadrillas bandoleras del Norte del Valle, en la violencia de los años cincuenta», Historia Crítica, n. ${ }^{\circ} 4$ (1990): 60.

342 Armando Moreno Sandoval. «El bandolerismo social revisitado. El caso del Norte del Tolima», Historelo Revista de Historia Regional y Local 4, n. ${ }^{\circ} 7$ (2012): 304. 
rural». Es clave reseñar que en este texto se describe la participación de campesinos en las cuadrillas de bandoleros. Al respecto decían:

Algunos de ellos (bandoleros) trabajaban en las haciendas, por tanto, presionaban a los mayordomos y administradores para establecer las condiciones de trabajo que ellos suponían correctas... Este aspecto resulta interesante, pues indica que los bandoleros eran campesinos que en sus tiempos libres se dedicaban a las bandas, no eran bandoleros de tiempo completo. En esta zona los trabajos eran estacionales, por tanto, podían combinar ambas actividades, o en el interín [sic], entre un trabajo y otro, podían dedicarse a las bandas. Este aspecto indica que los antiguos guerrilleros, si bien se insertaron de nuevo a las faenas del campo, igual siguieron ejerciendo presión en las haciendas, especialmente en lo que tiene que ver con las condiciones laborales en las mismas, lo cual pudieron llevar a cabo dada su reputación de guerrilleros ${ }^{343}$.

Por otro lado, para el presente capítulo es de suma importancia evaluar la conformación de los grupos de autodefensa y de las cuadrillas, pues se debe recalcar que estas agrupaciones se componían mayoritariamente de campesinos, lo cual hacía estériles los esfuerzos del Ejército en el proceso de pacificación de estas regiones y de su acción cívico-militar. De hecho, esta es una de las razones que alimenta el mito de ciertos bandoleros y su capacidad de mimetizarse, desaparecerse y hacerse invisibles ante el enemigo como en los casos del Capitán Venganza ${ }^{344}$ y de Efraín González ${ }^{345}$.

Este elemento da una pista para comprender los distintos grados de desarrollo de estas bandas, los cuales podían ir desde una etapa rudimentaria de autodefensa campesina, en donde

343 Diana Holguín Henao, «Bandolerismo rural en el Bajo Cauca, Magdalena Medio y el Nordeste antioqueño (Colombia), 1953-1958», Historelo Revista de Historia Regional y Local 7, n. ${ }^{\circ} 14$ (2015): 300-301.

344 Álvaro Acevedo, «El símbolo de un Robin Hood vengador en el occidente de Colombia», Estudios humanísticos. Historia, n. ${ }^{\circ} 3$ (2004): 59.

345 Claudia Steiner, «Un bandolero para el recuerdo: Efraín González también conocido como "El Siete Colores"», Antípoda. Revista de Antropología y Arqueología, n. ${ }^{\circ} 2$ (2006): 238. 
a los trabajadores rurales se les asignan labores de defensa y vigilancia - como en el presente caso - ; hasta la conformación de un grupo con unidad de mando dedicado a la extorsión, el robo, el secuestro y el asesinato con móviles políticos y/o económicos. $\mathrm{Al}$ analizar los procesos de creación de grupos de autodefensa se observa que estos tienen una separación respecto de las cuadrillas de bandoleros. Un testimonio que sirve para captar esta diferencia se encuentra en las memorias del suboficial Evelio Buitrago, quien en su juventud formó un grupo de autodefensa con familiares y la ayuda del Ejército en la localidad de Sevilla (Valle del Cauca) para vengar la muerte de su padre. En concepto de este personaje, la autodefensa era la protección de la población por sí misma al facilitar y validar las tareas de las Fuerzas Armadas ${ }^{346}$. Luego, esto contrasta con su infiltración en la cuadrilla de bandoleros de Zarpazo en el municipio de Cartago, en la cual relata cómo la banda seleccionaba los hacendados a quienes se les exigían pagos forzosos por medio de los boleteos y eran contratados por políticos locales para cometer asesinatos con el fin de apropiarse de fincas cafeteras $^{347}$.

En este sentido, tampoco se puede pasar por alto el tipo de relaciones que se daban entre el terrateniente, los agregados y los jornaleros. Como lo señaló Arocha, los segundos jugaron un papel determinante dentro de la economía cafetera, pues al asegurar el dominio de la tierra al dueño y dar la cara a las posibles amenazas de las cuadrillas; podía en contraprestación maximizar la producción de café sin compartir los excedentes con el patrón. De esta manera, se podía mostrar la pérdida de cantidades del grano como contribuciones forzadas a las cuadrillas. Se debe mencionar también que los agregados o mayordomos podían ser forzados a dejar la propiedad rural para que la cuadrilla impusiera a alguien de su conveniencia ${ }^{348}$.

346 Evelio Buitrago Salazar, Zarpazo. Otra cara de la violencia (Bogotá: Fuerzas Militares, 1967), 17. 347 Buitrago, Zarpazo..., 54-60.

348 Jaime Arocha, La Violencia en el Quindio. Determinantes ecológicos y económicos del homicidio en un municipio caficultor (Bogotá: Ediciones Tercer Mundo, 1979), 177-184. 


\subsection{La población rural de Belalcázar en los años de La Violencia}

Caracterizar la sociedad rural del Antiguo Caldas, durante la década de los años cincuenta del siglo pasado, permite comprender el marco contextual bajo el cual se desarrolló La Violencia y descifrar el orden jerárquico y el tipo de mentalidad tradicional y católica en que estaba organizada dicha sociedad. Hacer esta revisión deja en entredicho tanto las evocaciones de una comunidad rural manipulable y sumisa políticamente, como la concepción del campesinado como grupo social homogéneo en el cual no hay distinciones económicas de acuerdo con el tipo de adscripción con la tierra. Se debe recalcar que al interior de esta masa de campesinos hubo o existían diferencias substanciales respecto de su pertenencia a distintos grupos étnicos, a su vinculación económica de acuerdo con la modalidad de la tenencia de la tierra y a factores culturales ${ }^{349}$.

De acuerdo con el Atlas Socioeconómico de Caldas de 1956, Belalcázar, escenario en el que tuvieron lugar los hechos del sumario en contra de la Banda del Negro Cadena, estaba dentro del radio de influencia de la ciudad de Pereira junto con los municipios de Filandia, Santa Rosa de Cabal, Marsella, Balboa, Viterbo, Santuario, Apía y Pueblo Rico. Esta subregión se caracterizó —en el periodo de estudio- por el auge de la industria cafetera como primer renglón económico, seguida por una ganadería bastante desarrollada en los valles de los ríos Cauca, La Vieja y Risaralda ${ }^{350}$.

349 Christie, Oligarcas..., 98.

350 Ministerio del Trabajo, Caldas. Memoria explicativa del «Atlas» socio-económico del departamento (Bogotá: Ministerio del Trabajo, 1956), 73. 
FigURA NRO. 30. Familia campesina caldense.

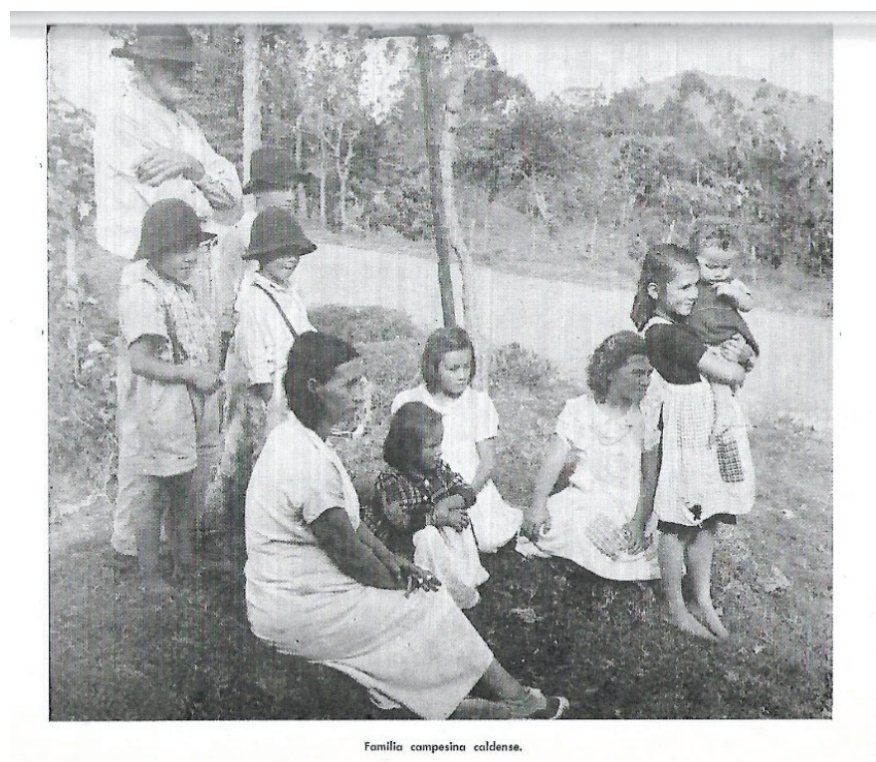

Fuente: Ministerio del Trabajo, Caldas. Memoria explicativa del Atlas Socio-económico del departamento (Bogotá: Ministerio del Trabajo, 1956), 96.

Estas actividades económicas fueron aprovechadas por la estratégica ubicación geográfica y las vías de comunicación que ofrecían las mejores condiciones para el ejercicio de transacciones económicas en el departamento. Esto facilitó «... más bajas tarifas de transporte, mejores precios para los artículos de compra y venta, mayor abundancia de entidades de crédito, más amplios plazos, etc. $[$ sic $] »^{351}$. Esta primera descripción permite enlazar a la geografía natural las actividades socioeconómicas del territorio, en las cuales van a estar insertas las actividades delictivas de los bandoleros de la región y se dará cuenta del comportamiento de la lucha bipartidista de este periodo.

351 Ministerio del Trabajo, Caldas. Memoria..., 73. 
Cabe mencionar que para el caso del departamento de Caldas, hacia el año 1951, las pequeñas fincas - menores de cinco hectáreas - conformaban la mayoría de las propiedades rurales con un porcentaje del $56 \%^{352}$, y se estimaba que de 346 751 personas económicamente activas, 213206 se dedicaban a actividades agrícolas o de ganado, o sea el $61.50 \%$, los cuales se dividían en jornaleros temporales y de tiempo completo, aparceros, arrendatarios de varias clases y pequeños propietarios.

En 1953, el municipio de Belalcázar tenía una extensión de $134 \mathrm{~km}^{2}$ y 1122 fincas rurales ${ }^{353}$ con un tamaño promedio de 11.9 hectáreas y predominio de espacios cafeteros y ganaderos de tierra cálida ${ }^{354}$. Entre 1945 y 1953 se presentó un aumento de la finca raíz en el área rural de dicha localidad al ocupar el $76.9 \%$, gracias a la apertura de nuevos frentes de colonización $\mathrm{y}$, principalmente, por la presión demográfica producto de la violencia y la consiguiente parcelación de las propiedades ${ }^{355}$. Su población había crecido significativamente en la primera mitad del siglo XX, al pasar de 3107 habitantes en 1912, a 13425 en 1938, para alcanzar la cifra de 16378 en $1951^{356}$. De esta cifra d la inmensa mayoría correspondía a una población rural con 15600 personas ${ }^{357}$. En términos de distribución de los pisos térmicos, el municipio contaba con un suelo templado de 11600 hectáreas, las cuales se dedicaban al cultivo del café y unas 2000 hectáreas a otros cultivos. 1500 personas laboraban en el piso térmico cálido en actividades agrícolas y 500 se ocupaban en labores correspondientes a la ganadería ${ }^{358}$.

No obstante, este escenario socioeconómico caldense estaba acompañado de grandes tensiones sociales en donde el conflicto bipartidista tomó cauces violentos, en un proceso que tenía sus

352 Christie, Oligarcas ..., 59.

353 Ministerio del Trabajo, Caldas. Memoria ..., 95.

354 Ministerio del Trabajo, Caldas. Memoria..., 98.

355 Ministerio del Trabajo Caldas. Memoria..., 100.

356 Ministerio del Trabajo Caldas. Memoria..., 101.

357 Ministerio del Trabajo, Caldas. Memoria..., 103.

358 Ministerio del Trabajo, Caldas. Memoria..., 274-275. 
antecedentes en la colonización de dichas tierras a finales del siglo xIx y que alcanzó su punto máximo a mediados del siglo xx. Para comprender mejor el carácter conflictivo de la región, en torno a la tenencia de la tierra y la producción agrícola, debe tenerse en cuenta que dicha simiente fue sembrada desde el proceso mismo de poblamiento y fundación de la localidad. El conflicto inicial entre colonos y empresarios agrícolas estuvo presente desde la época de colonización de dicho territorio

Donde las compañías comerciales de Medellín se disputaban diez mil hectáreas de tierra con unos dos mil colonos antioqueños, quienes habían emigrado hacia el sur en la década de 1890 para fundar el municipio. Esta disputa, en la cual la mayor parte de la población de Belalcázar tomó parte, no se resolvió sino hasta después de $1925^{359}$.

Es más, el conflicto desde sus inicios tuvo visos partidistas, pues los colonos -en su mayoría liberales - respaldaron electoralmente a los abogados que los representaron en los litigios en contra de los terratenientes de filiación conservadora ${ }^{360}$. De esta manera, el repertorio de acciones de los terratenientes cubría lo legal y lo delictivo. Legalmente en 1904, varios de ellos entablaron un litigio en contra de Bonifacio Torres Peña, líder de los colonos, por falsificación de firma en Anserma ${ }^{361}$; dicho personaje fue encarcelado durante seis meses por las autoridades locales ${ }^{362}$. Por fuera de la ley en 1907, un terrateniente dejaba en claro lo siguiente: "Aquí, donde es ineficaz la acción de la autoridad, tendrán los propietarios no muy tarde que organizar cuadrillas para hacer respetar lo que tan legítimamente han adquirido» ${ }^{363}$.

359 Catherine LeGrand, «De las tierras públicas a las propiedades privadas: acaparamiento de tierras y conflicto agrarios en Colombia, 1870-1936», Lecturas de Economía, n. ${ }^{\circ} 13$ (1984): 36. 360 Catherine LeGrand, Colonización y protesta campesina en Colombia (1850-1950) (Bogotá: Ediciones Uniandes-Universidad de Los Andes, 2016), 109.

361 Diario Oficial, República de Colombia, Bogotá, miércoles 29 de 1913: 183.

362 LeGrand, Colonización..., 114.

363 LeGrand, Colonización..., 127. 
Las tensiones y conflictos entre terratenientes y colonos siguieron desarrollándose en la región hacia la década de los años treinta. Así, en 1935 se registró el desalojo de unos ciento cincuenta colonos en zonas aledañas al río Cauca, quienes se habían instalado allí desde 1920. El desalojo tuvo como base jurídica una resolución del Ministerio de Industria, en 1935, que le otorgó derechos de propiedad sobre dichas tierras a un importante hacendado. Esta situación se repitió en la Hacienda El Retiro, la cual fue ocupada y de donde también fueron expulsados los invasores ${ }^{364}$. Una década más tarde, para 1947, la confrontación bipartidista ya tenía lugar en dicha población con la conservatización armada de la localidad. Por eso decían:

En el occidente de Caldas se decomisa gran cantidad de armas y aparecen en Santuario y Belalcázar los primeros grupos de violentos, que posteriormente se llamarían pájaros, organizados por un alto y prestigioso jefe político. Estos con sus incursiones produjeron el destierro de elementos liberales de las poblaciones para extender luego su acción depredatoria sobre el área rural, causando numerosas víctimas y alterando así la composición política de provincias enteras ${ }^{365}$.

Prueba de la intensidad de La Violencia fue el incremento de la tasa de asesinatos durante el transcurso de los años cincuenta en Caldas, elevándose desde dicho año de 30 homicidios por 100000 habitantes, a 52 homicidios por cada 100000 habitantes en 1955; cifra que llegó a 60 asesinatos en $1961^{366}$. Tres zonas del departamento se destacaban por la intensidad de la violencia durante este periodo; la primera era la zona del Quindío delimitada por los municipios de Calarcá, Salento, Pijao y Génova donde operaban «Chispas» y Efraín González; la segunda correspondía al noroeste caldense en las localidades de Quinchía, Riosucio, Guática, Mistrató y Belén de Umbría bajo el

364 Christie, Oligarcas..., 78.

365 Campos, Fals y Umaña, La Violencia ..., 47.

366 Christie, Oligarcas..., 70. 
dominio del «Capitán Venganza» y «Pedro Brincos»; y la tercera zona concernía al occidente del departamento, el cual reunía las poblaciones de Belalcázar, Marsella, Viterbo, Balboa y Santuario, espacios azotados por Bernardo Gutiérrez y el «Pollo Idárraga» ${ }^{367}$. Al mismo tiempo, ocurrió un fenómeno de migración forzosa hacia las poblaciones de Pueblo Rico, Anserma, Riosucio, Pereira y Manizales con un número cercano a las 180000 personas $^{368}$. Este es el escenario bajo el cual van a acontecer los hechos que se presentan a continuación. En este las vías de hecho se consolidaron como uno de los mecanismos utilizados para resolver las tensiones sociales sobre la tenencia de la tierra en esta localidad.

\subsection{La Banda del Negro Cadena: jornaleros o chusmeros.}

El 16 de junio de 1958, en el despacho de la Alcaldía de Belalcázar, el comandante de la Estación de Policía del municipio, el cabo primero Armando González U., bajo la gravedad del juramento ratificaba el informe en el cual se daba cuenta de la captura - el día anterior, en la hacienda La Moravia de la región de San Isidro- de trece sujetos «... que parece que fueran integrantes de la famosa banda del Negro Cadena la cual ha venido sembrando el pánico en estas regiones por repetidas ocasiones» ${ }^{369}$.

La captura se había dado por dos informaciones que mencionaban la posibilidad de apoyo en dicha hacienda a la Banda del Negro Cadena. Los indicios se podrían entender más como rumores, pues en todo caso no existían denuncias concretas, lo cual daba lugar a muchas dudas. El supuesto apoyo a la banda de malhechores fue corroborado tres días después por dos testigos: el primero, Enrique Torres Ramírez de cuarenta años, natural de Anserma y vecino de Belalcázar, quien en su versión ante el alcalde

367 Policía Nacional, «Análisis general situación orden público-Caldas». Revista Criminalidad, n. ${ }^{\circ} 1$ (1958): 14-27.

368 Christie, Oligarcas..., 71.

369 Alcaldía Municipal Belalcázar, Sumario Penal. Delito de la asociación e instigación para delinquir. Sindicados Alejandro Sotelo, Gonzalo Torres y otros. Ofendida la sociedad (Belalcázar: Archivo Judicial Anserma, 1958), folio 2. 
de la población mencionó: "yo he oído decir que a esa cuadrilla la están sosteniendo en la hacienda La Moravia ese señor de Pereira ${ }^{370}$. Torres Ramírez además agregó que, para ese tiempo, el dueño de dicha propiedad

... les proporciona escopetas para coger café con dichas armas terciadas y los auxilios que atrás dejé narrados y también tengo conocimiento que en la finca La Moravia el dicho Negro tiene dos bestias de su propiedad y en las cuales se moviliza ${ }^{371}$.

El segundo testimonio que dio lugar a la detención de los campesinos fue la declaración de Dolores Galvis de Salazar de cuarenta y nueve años, viuda y natural de Jardín (Antioquia). Esta señora señaló que el primero de junio del mismo año, al desplazarse a vivir y trabajar en dicha hacienda junto con sus hijos como agregados, hacia las ocho de la noche un grupo de más o menos catorce hombres armados irrumpió en su casa para averiguar la filiación política de sus hijos, advirtiéndole que si ellos «eran liberales podían ir a trabajar, porque de lo contrario serían un bocao para esa lionera de la región ${ }^{372}$. El grupo de hombres se habría basado en una persona del pueblo, la cual les contó que la familia de la viuda era muy conservadora. Para Galvis dos hechos delataron a estos personajes como bandoleros, pues en primera instancia cuando una de sus hijas le agradeció a uno de los visitantes por un cigarrillo obsequiado, el hombre respondió con la siguiente frase: «No soy digno de las gracias señorita, porque soy un chusmero ${ }^{373}$. Acto seguido, el mayordomo de la finca, Gonzalo Torres, le dijo «que era que él tenía varios chusmeros para cuidar la hacienda, los cuales enviaba el señor Teófilo Pulgarín, dueño de la misma» ${ }^{374}$.

Al revisar detenidamente en el sumario judicial la procedencia de los sujetos señalados de pertenecer a la cuadrilla, después de

370 Alcaldía Municipal Belalcázar, Sumario penal..., folio 18. 371 Alcaldía Municipal Belalcázar, Sumario penal..., folio 18. 372 Alcaldía Municipal Belalcázar, Sumario penal..., folio 21. 373 Alcaldía Municipal Belalcázar, Sumario penal..., folio 22. 374 Alcaldía Municipal Belalcázar, Sumario penal..., folio 22. 
las indagatorias, las ruedas de reconocimiento y los careos en el despacho de la alcaldía, se desprende que el grupo de trece hombres detenidos estaba conformado por el mayordomo de la hacienda y doce trabajadores de la misma, sus edades comprendían entre los dieciocho y treinta y ocho años de edad, sin propiedades o bienes de valor, en su mayoría analfabetas que tan solo sabían escribir su nombre y quienes hacía tres meses trabajaban en la hacienda La Moravia de propiedad del señor Teófilo Pulgarín. El grupo se dividía en seis trabajadores nacidos en Belalcázar, uno en Risaralda - localidad vecina-, cuatro de Supía, uno de Honda y otro de Caramanta ${ }^{375}$. En el proceso, los cinco sujetos a quienes se les dictó auto de detención preventiva por el delito de asociación e instigación para delinquir eran de municipios foráneos; estos fueron identificados como Gonzalo Torres Palacio (mayordomo, Caramanta), Ramón Velarde (Supía), Alejandro Zotelo (Honda), Guillermo Torres (Supía) y Gildardo Orozco (Supía). El resto de los campesinos sindicados fueron liberados el 22 de junio ${ }^{376}$.

Respecto a la sindicación del delito de asociación para delinquir y de la pertenencia o no de estos agricultores a la Banda del Negro Cadena se sacan las siguientes conclusiones. La primera es el aura de misterio de la figura del Negro Cadena y la dificultad de demostrar fehacientemente que en dicha hacienda operaba la cuadrilla mencionada. Dicha persona, en realidad, parecía ser un fantasma debido a que, en las declaraciones hechas, tanto por los testigos como por los campesinos sindicados, se señalaba que todos habían oído de él, pero nadie lo conocía, por lo cual cabía la posibilidad de que rondara un enorme temor entre los habitantes o incluso complicidad. Denunciantes y denunciados se entremezclaban en un contrapunteo de testimonios sobre este personaje, ya que los primeros afirmaban haberlo reconocido sin

375 Alcaldía Municipal Belalcázar, Sumario penal..., folios 3-17.

376 Los trabajadores liberados con sus respectivos lugares de procedencia fueron: Luis Arturo Buitrago Urrea (Belalcázar), Dorance Henao Grajales (Belalcázar), Odulfo Vásquez (Belalcázar), Marco Tulio Montoya Buitrago (Belalcázar), Luis Aníbal Bedoya Buitrago (Belalcázar), Argemiro Arenas Porras (Belalcázar), Israel Castañeda Rivera (Risaralda) y José María Orozco (Supía). 
poder señalarlo de forma cierta y los últimos negaban conocerlo, aunque afirmaban que sus andanzas eran vox populi.

En los interrogatorios de los trabajadores, una y otra vez, se lee que simplemente le habían oído mentar o hablar mucho de su cuadrilla; que era un asesino, un tipo muy malo y peligroso pero que no le conocían personalmente. De hecho, estas versiones demuestran, entre los capturados, un ánimo de reafirmar que no tenían ningún tipo de vínculo con el Negro Cadena, aun cuando tuviesen que contradecirse como lo hizo Gonzalo Torres, mayordomo de la finca en careo con el denunciante Enrique Torres, quien declaró tajantemente sobre el bandolero al mencionar lo siguiente: «ese señor nunca visita la finca La Moravia» ${ }^{377}$, esto a pesar de manifestar un poco después: «yo no conozco a tal sujeto, pues únicamente lo he oído mentar mucho». ¿Si no lo conocía porque estaba seguro de nunca haberlo visto en la finca? Todas las fuentes de información sobre el Negro Cadena y su cuadrilla de bandidos parece que obedecían a murmuraciones, a algo que oyeron, a lo que se dice por ahí, al chisme y a la delación. Debido a esto, se creó una cultura del rumor, en la cual cada uno de estos personajes trataba de salvar sus propios intereses.

Sin embargo, una declaración de Ramón Velarde, uno de los sindicados, deja entrever un indicio de mayor luz. Al preguntar sobre cómo podía explicar el motivo de habitar dicha región y no saber nada del mencionado bandolero, tras haber negado tener conocimiento del mismo, dijo: "Yo sí le he oído mentar a él, es decir El Negro Cadena, a El Gurre y al Sirineo [sic] nada más» ${ }^{378}$. Los nombres de estos otros dos bandoleros de la región si eran reconocidos por la Policía Nacional, pues ese mismo año habían sido reseñados en un informe sobre el orden público en el departamento de Caldas:

377 Alcaldía Municipal Belalcázar, Sumario penal..., folio 19-20.

378 Alcaldía Municipal Belalcázar, Sumario penal..., folio 5. 
En la región propiamente occidental comprendida por los municipios de Marsella, Belalcázar, Balboa, Viterbo y Santuario [...]. Igualmente fue importante en este sector hasta hace cerca de seis meses la cuadrilla comandada por el Negro GREGORIO LEDESMA [ sic] (Cirineo) con sus segundos LEONARDO RIVERA [sic] (El Gurre) y HUMBERTO RAMÍREZ [sic] (Tínguaro). Esta última cuadrilla se disolvió (por acción de la policía) ${ }^{379}$.

En este caso, con la información disponible la justicia local no consiguió determinar que estos campesinos conformaran la Banda del Negro Cadena. Otro tanto se advierte en el veredicto del Tribunal Superior de Manizales, el cual los absolvió del delito del que se les sindicaba porque su comportamiento no cumplía con los elementos que tipificaban la acusación de asociación e instigación para delinquir. Esta situación no indica que sea imposible constatar el accionar de ciertos maleantes como parte de la violencia acaecida durante aquellos años en esta zona de Caldas.

Por otro lado, se puede observar que mediante la revisión detallada de los comportamientos visibles en las labores agrícolas de estos campesinos en el sumario, se da un proceso rudimentario y preventivo de autodefensa de la propiedad rural ${ }^{380}$. Se hace referencia a una serie de acciones y situaciones que insertaron a unos cuantos jornaleros de la hacienda La Moravia en labores de vigilancia y de cuidado, con tintes partidistas, con el fin de mantener fuera del territorio personas del partido político adversario. Situación que concuerda con una de las tipologías señaladas por Sánchez y Meertens para el bandolerismo político en el país, que tiene que ver con la forma en la cual:

La dominación oligárquica a través del bipartidismo, en regiones en cuya estructura agraria predominan las relaciones precapitalistas, con particular incidencia de la aparcería, adquieren una dinámica de ruptura gradual, aunque inconclusa, respecto a propietarios y jefes políticos de la zona ${ }^{381}$.

379 Policía Nacional, «Análisis general...», 22.

380 Sánchez y Meertens, Bandoleros..., 39.

381 Sánchez y Meertens, Bandoleros..., 62. 
Es así como, entre 1958 y 1965, tuvo lugar en el occidente caldense, una fase de bandolerismo político en el que las bandas activas, constituidas por grupos de campesinos armados más o menos organizados con el apoyo militante o pasivo de las comunidades rurales de su misma identidad partidaria y con orientación de gamonales, reflejaban la tensión por el poder local o regional ${ }^{382}$. Al examinar las diligencias judiciales llevadas a cabo en este caso, se puede advertir sobre sectarismo político vivido en la cotidianidad de la región, pues la selección y vinculación de los agregados en la hacienda pasaba por un tamiz partidista. En el caso de la señora Dolores Galvis y su familia descrito por Alejandro Zotelo, jornalero de la finca, tras oír los cargos de aquella mencionó:

Yo no me fui con ella, sino que me fui más tarde y como yo me quedé me preguntó un tipo que no conozco y no se dar la filiación: Que, si era cierto que me había llevado a la familia de Galvis, le dije que sí, que por qué me hacía esa pregunta, entonces me respondió él: Que él sabía que allá en La Moravia le hacían viajes a uno, y que no convenía porque estos muchachos Galvis eran muy conservadores y muy sectarios.

La confirmación de la adscripción partidista era un elemento primordial en dicha sociedad rural ante la constante y fluida movilización de mano de obra a lo largo del territorio en periodos de cosecha. Ante el rumor de la pertenencia de los nuevos agregados al conservatismo, seguramente, a Gonzalo Torres (mayordomo) le fue comunicado esto por parte de Zotelo en cuanto llegó a la hacienda; y más tarde en la noche - cuando visitaron a la familia Galvis - tuvo lugar la averiguación por la filiación política de los hijos declarada por la señora Dolores, quien incluso fue advertida de la visita nocturna a la que iban a verse sometidos por otra mujer, Soledad Mejía.

382 Sánchez y Meertens, Bandoleros..., 42. 
Sin embargo, el desarrollo de esta indagación tuvo un progreso particular, ya que una vez arribó el grupo de hombres a la casa asignada a los Galvis, al tomar la vocería el señor Torres Palacio, este le preguntó a la señora Dolores que si ella había recibido la razón que él le había enviado con Zotelo. Ella respondió que no. Acto seguido, en la versión de ella se señala que el mayordomo Gonzalo Palacio le estudió el «físico de liberal», a lo cual le contestó que si ella lo era igualmente lo serían sus hijos. De allí, Zotelo se dirigió donde Evelio, hijo de la señora Galvis, y le preguntó por la filiación política, a lo cual el joven respondió que él no tenía papeles de ninguna clase porque era menor de edad ${ }^{383}$.

Ello podría significar que la develación sobre la supuesta inclinación política de esta familia hacia el conservatismo fuera un elemento desconocido para Zotelo, quien no lo supo en el mes anterior que la señora Dolores le estuvo pidiendo trabajo y, por lo tanto, fue una cuestión a averiguar en la ronda nocturna del grupo de trabajadores de la hacienda La Moravia. Difícilmente, se podría creer que una información tan relevante se le hubiese pasado por alto a Zotelo cuando recogió a la familia en el perímetro urbano de la localidad. Por ello, se tiene la sensación de ser una reacción instantánea ante el conocimiento de dicha información. Además, cabe resaltar que este punto de la declaración sobre la amenaza partidista en contra de la familia Galvis no fue desmentido ni se encuentra alusión alguna por parte de los sindicados en el sumario, lo cual abre la posibilidad de que la misma haya sido cierta. Toda la trama de testimonios en el caso se diluyó en incongruencias y evidencias acomodadas, lo cual da cuenta del peligro inminente, del uso de silencios y de versiones distintas.

Otro punto crucial durante las averiguaciones preliminares por la sindicación de asociación para delinquir y, específicamente, por ser ayudantes de la Banda del Negro Cadena, giró en torno a la denuncia del porte de armas en las rondas de cuidado del ganado por la noche. Este era un punto sensible, pues podía ser un elemento

383 Alcaldía Municipal Belalcázar, Sumario penal..., folio 22. 
de juicio para comprobar el delito del cual fueron acusados los trabajadores de la hacienda. En su declaratoria, Gonzalo Torres mencionó que sí «iba en compañía de los trabajadores pero como dice ella, ahí no iba el negro cadena, iba por ahí por la casa y darle vuelta al ganado, pues yo cuido ese ganado constantemente» ${ }^{384} \mathrm{y}$ que quienes lo acompañaron fueron según él «el señor Alejandro Zotelo, Guillermo Torres, Ramón Velarde, Aníbal Bedoya, no recuerdo el nombre de los otros pero en total éramos cinco y de ellos el único que portaba armas era yo» ${ }^{385}$, lo cual concordaba parcialmente sobre el cuidado del ganado pero no en el número de integrantes con la versión de Zotelo, quien dijo: «claro que si le hicimos visita unos ocho, pero armas no se llevaban, porque nosotros no íbamos en persecución de ellos, le íbamos a dar una vuelta al ganado» ${ }^{386}$; y con la de Velarde que expresó: «nosotros sí fuimos pero a cuidar el ganado» ${ }^{387}$.

De hecho, Velarde, en una declaración posterior, da entender que el grupo de trabajadores que hacían la ronda nocturna para cuidar el ganado, los cuales habían llegado de Supía, cumplían con labores de vigilancia dentro de su trabajo agrícola. Así, describió las actividades que llevaba a cabo diariamente dentro de la hacienda con sus compañeros:

Nosotros nos mantenemos es cuidando el ganado de noche y después ya nosotros nos vamos a dormir pero ya es tarde de la noche y al otro día madrugamos a cuidar las bestias, picando cuido y ordeñando las vacas y por la tarde nos vamos a encerrar ${ }^{388}$.

La reconstrucción del contexto social, político y económico en el cual se insertan estos acontecimientos narrados en el sumario y reseñados anteriormente concuerdan con la periodización propuesta por Betancourt para el fenómeno bandolero en el

384 Alcaldía Municipal Belalcázar, Sumario penal..., folio 23. 385 Alcaldía Municipal Belalcázar, Sumario penal..., folio 23. 386 Alcaldía Municipal Belalcázar, Sumario penal..., folio 24. 387 Alcaldía Municipal Belalcázar, Sumario penal..., folio 25. 388 Alcaldía Municipal Belalcázar, Sumario penal..., folio 25. 
Norte del Valle del Cauca -zona limítrofe con el municipio de Belalcázar- en el cual, hacia 1955, se configuró la resistencia liberal manifestada en la conformación de cuadrillas armadas como respuesta a la arremetida conservadora que desde 1946 se llevó a cabo a cargo de los pájaros y la policía política. En consecuencia, se dio una respuesta violenta desde la población campesina que, amparada en las filiaciones partidistas, reivindicó el aspecto económico en el caso de las cuadrillas y los bandoleros ${ }^{389}$.

La Banda del Negro Cadena, real o no, era parte de una sociedad rural compuesta por campesinos que se encontraban bajo diferentes relaciones sociales de producción en una hacienda cafetera y ganadera. En ella se hallaban o interactuaban el mayordomo, los jornaleros estacionales y los aparceros venidos de otras localidades de la región para desempeñar labores agrícolas que alternaban con actividades de seguridad y defensa. A ello se sumaban las familias de nuevos agregados, a veces encabezadas por mujeres viudas con sus hijos, cuya inclusión en la finca dependía, en gran medida, de ser copartidarios del dueño de la hacienda. Estas funciones de vigilancia se debían a los constantes ataques a los que estaba sometido dicho espacio, para lo cual se conformó un grupo rudimentario y embrionario de autodefensa del que se hablará a continuación.

Igualmente, se destaca en las respuestas dadas por los involucrados en la reconstrucción de los hechos, cómo todos estos personajes tenían que aprender a desarrollar elecciones racionales para obtener y salvaguardar su sustento económico. En el caso de los jornaleros el acceso a un puesto de trabajo temporal durante la cosecha, además de la adscripción partidista, estaba mediado por recomendaciones de personajes reconocidos de la localidad ante el agregado o mayordomo de la finca. De la misma manera, ocurrió con la familia de agregados, quienes tuvieron que ponerse a salvo de los señalamientos de pertenencia al partido político contrario para poder trabajar en la hacienda $y$, en el mismo sentido, el

389 Betancourt, «Las cuadrillas bandoleras...», 58-59. 
mayordomo de la finca tenía que estar al tanto del conocimiento del personal contratado. Así, las dinámicas sociales del mundo rural caldense de los años cincuenta dan cuenta de personas racionales que defendían sus intereses y se involucraban en juegos de identidades partidistas para poder trabajar y sobrevivir.

Figura NRO. 31. El cañón del río Cauca en Belalcázar.

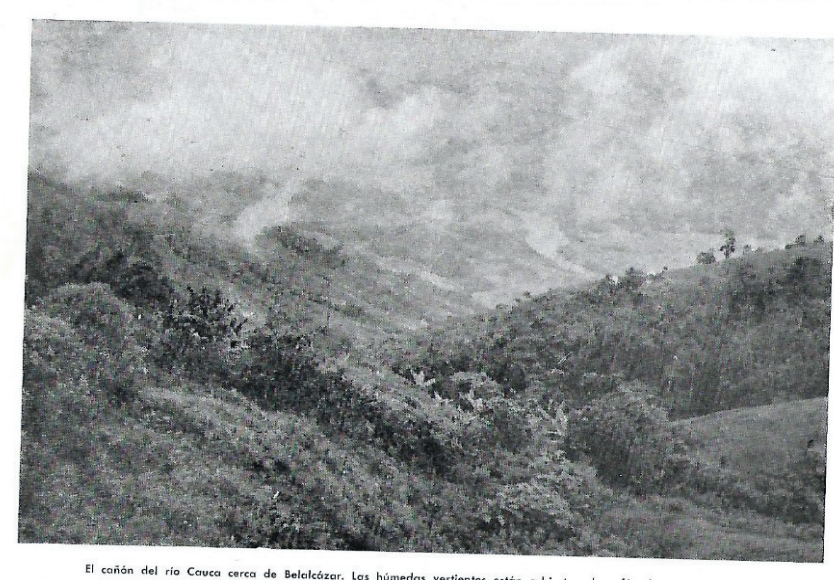

Fuente: Ministerio del Trabajo, Caldas. Memoria explicativa del «Atlas» socio-económico del departamento (Bogotá: Ministerio del Trabajo, 1956), 353.

\subsection{Un pájaro, la chismografía y un hacendado liberal asediado}

La agrupación de la finca La Moravia fue objeto de rumores difundidos por algunos vecinos y el mismo mayordomo, razón por la cual fueron asociados como chusmeros de la Banda del Negro Cadena; cuadrilla que, en dicha época, realizaba operaciones delictivas en la zona rural de dicho municipio. Al llegar esta información a oídos de las autoridades, la policía local procedió a detener los trabajadores sin existir una denuncia penal o la orden de un juez. Acto seguido, las investigaciones y los interrogatorios 
fueron conducidos por el alcalde del municipio quien, tras expedir auto de detención contra cinco de ellos, los trasladó al Batallón San Mateo de Pereira para su judicialización ante un juez penal militar. Cabe recordar que los delitos de orden público eran competencia de la Justicia Militar bajo la declaratoria de estado de sitio desde 1950. En julio de 1958 dichos delitos pasarían a consejos verbales de guerra sin la necesidad de haber sido declarado el estado de guerra, de turbación del orden público o de conmoción interior ${ }^{390}$.

La defensa de la acusación en contra de los trabajadores estuvo a cargo del abogado Marco Antonio Rojas. En las comunicaciones enviadas al alcalde de Belalcázar y demás jueces encargados del caso solicitó la liberación de los sindicados y salieron a la luz la contracara de los múltiples ataques recibidos por el hacendado Teófilo Pulgarín. De esta forma, dicho abogado defensor denunció que Enrique Torres, primer testigo, era conocido ampliamente en el municipio como un "pájaro» y que Dolores Galvis había sido obligada a dar falso testimonio en contra de los trabajadores. Las denuncias sobre el supuesto apoyo a la Banda del Negro Cadena en la hacienda La Moravia, en consideración del abogado Rojas, obedecían a una estrategia que, a pesar del tinte partidista, tenía como objetivo obligar al dueño de la hacienda a vender la misma.

Además de lo anterior, el abogado también puso en conocimiento, tanto del alcalde Corzo como del Juez Penal Militar, la investigación adelantada por Pedro Nel García, investigador departamental del Gobierno, con motivo del atentado que sufrió el dueño de la hacienda, Teófilo Pulgarín, cuando este acudió a la localidad de Belalcázar para estar pendiente del proceso judicial en contra del grupo de trabajadores. De la siguiente manera lo expresó:

390 Martha Perdomo Chamucero, «De La Violencia al Frente Nacional: evolución de la Justicia Penal Militar como instrumento de represión política y sanción de la protesta social» (Tesis de Maestría en Estudios Políticos, Universidad Nacional de Colombia, 2010), 50. 
Algunos individuos, que el veinte de los corrientes y poco más o menos a eso de las cuatro de la tarde asaltaron la camioneta en que viajaba el Sr. Teófilo Pulgarín y varios de sus hijos, asalto este que no tuvo las consecuencias que los atacantes deseaban, debido a la presencia del señor Alcalde [sic] de la población y a una patrulla de cinco agentes que lo acompañaban. Que tales hechos tuvieron ocurrencia en la carretera que de esta cabecera conduce al corregimiento de La Virginia, en el punto denominado La Vuelta del Diablo ${ }^{391}$.

Este atentado era una de las acciones que, de tiempo atrás, se sumaban a una campaña de hostigamiento en contra de Teófilo Pulgarín para forzar la venta de la hacienda a un precio irrisorio $^{392}$. La víctima había tenido que abandonar su propiedad como resultado de otro atentado anterior en el cual fue herido. Así, desde aquel primer incidente en el que casi pierde la vida, el reporte mencionaba lo siguiente:

... le han quemado cinco casas para trabajadores, le han robado no menos de 200 cabezas de ganado y unas 100 cargas de café, y heridos varios mayordomos. Muchos de estos robos eran hechos solidariamente con los mayordomos que atemorizados por los bandoleros accedían a ello ${ }^{393}$.

391 Alcaldía Municipal Belalcázar, Sumario penal..., folio 43.

392 Junto a la descripción de estos hechos, el abogado defensor adjuntó copia de las denuncias de los robos y hostigamientos que desde el año anterior sufría Pulgarín. La primera denuncia hecha el 24 de mayo de 1957 relataba en orden: primero el robo de catorce reses durante el año de 1956; luego, el ataque en contra de su antiguo mayordomo Julio César Vásquez, quien fue herido al recibir disparos desde un monte ocurrido el 6 de abril de dicho año; días más tarde, el 27 del mismo mes, el incendio de una de las casas de la hacienda; y posteriormente, el ataque de un grupo de hombres armados «quienes disparando continuamente, pusieron en fuga a mis trabajadores, amenazándolos de muerte si presentaban resistencia, llevándosen [sic] 50 arrobas de café». Sobre la incursión armada en la misma denuncia, los trabajadores de la finca señalaron como autores materiales del robo de café a los señores «Obed Londoño, Gildardo Agudelo, Silvio Gallego Valencia, Jorge Gallego, Jesús Zaraza y Rafael Correa (a. Lelo). Jesús y Luis C. Valencia-Rómulo Vásquez». En el resto de los comunicados con fechas de mayo 30, junio 2 y 22 de 1957, el señor Teófilo Pulgarín acusó el robo continuo de reses en su hacienda.

393 Alcaldía Municipal Belalcázar, Sumario penal..., folio 46. 
Este escenario de amenazas y persecución se había recrudecido debido a que el mayordomo de La Moravia, Gonzalo Torres, no se había prestado a intimidaciones de ladrones de la región, «sino que junto con sus trabajadores se ha[bían] enfrentado a la defensa de la finca, hecho que le produjo enemistades, odios y persecución armada de parte de los antisociales» ${ }^{394}$. En este sentido, habían

... apelado últimamente a la chismografía, valiéndose de la atención que la Policía les presta, como el caso en que nos estamos ocupando, donde quieren hacer creer que él tiene en su finca una cuadrilla para delinquir, sin que hasta el momento haya el primer denuncio o sumario contra él y sus peones ${ }^{395}$.

\section{Conclusiones}

Estudios anteriores han señalado la importancia de las motivaciones e intereses políticos y económicos de las distintas clases sociales subyacentes en el periodo de La Violencia en la zona cafetera. Entre los temas más conocidos están el papel primordial de la figura del mayordomo quien «disponía, entonces de todos los medios de producción y decidía sobre el destino de las cosechas» ${ }^{396}$, del sistema de aparcería, del camuflaje social de los bandoleros entre los campesinos, entre otros. Pero al evaluar este caso desde una perspectiva local, es posible vislumbrar toda una trama de estrategias de los distintos actores en dicha sociedad rural.

Así, en primer lugar, no se puede verificar completamente si los campesinos en realidad conformaban la cuadrilla del Negro Cadena en la hacienda La Moravia, pero al estar armados estos jornaleros y agregados, quienes cumplían con labores de vigilancia ante las amenazas y robos continuos de ganado y café, sí se advierte un rudimentario proceso de autodefensa campesina.

394 Alcaldía Municipal Belalcázar, Sumario penal..., folio 47. 395 Alcaldía Municipal Belalcázar, Sumario penal..., folio 47.

396 Sánchez y Meertens, Bandoleros..., 58. 
Además, no sobra recordar que en esta época el Ejército ayudó a preparar escuadrones de aquellas en una de las modalidades de la intervención cívica-militar bajo una estructura jerárquica, la cual llegaba hasta las mismas brigadas ${ }^{397}$.

Estas actividades de vigilancia se esparcieron como rumores en la zona rural de San Isidro en Belalcázar, en forma de la existencia de una cuadrilla de chusmeros liberales al mando del Negro Cadena, la cual todos decían haber oído que existía pero que nadie conocía a ciencia cierta. La propagación de estos señalamientos por ciertos vecinos y la confirmación, ambiguamente, por el mayordomo de la hacienda llegó a oídos de las autoridades, todo ello por parte de un sujeto que fue acusado de ser un pájaro conservador, el cual quería apropiarse de la hacienda y, quizás, hacía parte de una estructura delincuencial mayor; y por una mujer viuda, cabeza de familia con tres hijos, los cuales fueron interrogados por su filiación política — de forma amenazante - al vincularse en la hacienda por otro rumor que los señaló como partidarios del conservatismo.

Estas denuncias ambiguas dieron pie a que el alcalde de la localidad detuviera a trece trabajadores de la hacienda, sin la existencia de una denuncia formal, y los enviara ante un juez militar para su juzgamiento por el delito de asociación para delinquir. Luego, en la defensa jurídica contratada por el hacendado se recalcaron todos los atentados, hostigamientos, robos y ataques armados sufridos en el espacio en cuestión, los cuales obligaron al dueño de la hacienda a armar a sus trabajadores.

De esta forma, se contrasta el mito de la sociedad campesina igualitaria del Viejo Caldas producto de la colonización antioqueña, pues la conformación de la tenencia de la tierra

397 Jhon Jaime Correa Ramírez, Edwin Mauricio López García y Natalia Agudelo Castañeda, «Botas para salvar la democracia en la Gobernación de Caldas 1953-1967». En Apropiación social del conocimiento investigación, innovación y extensión en 2019 (Vicerrectoría de Investigaciones, Innovación y Extensión (Pereira: Universidad Tecnológica de Pereira, 2019), 356. 
y las relaciones de producción económica de dicha sociedad demuestran un orden jerárquico rural de hacendados, agregados y jornaleros móviles que se trenzan en relaciones económicas y políticas asimétricas. Además, estos dispares vínculos de poder económicos y sociales, traspasados por tintes partidistas, ponen en cuestión ciertas explicaciones culturales mecanicistas del campesinado como un grupo social sumiso y manipulable, pues permiten entrever la racionalidad de la mano de obra campesina para defender sus propios intereses durante los interrogatorios del sumario tanto en el caso de Dolores Galvis, y su familia como en el del mayordomo y los jornaleros foráneos. El proceso judicial duró desde 14 de junio de 1958, momento de la captura de los trece campesinos, hasta el 30 de noviembre de 1964, fecha en la cual el Tribunal Superior de Caldas con ponencia del doctor Clímaco Sepúlveda, declaró que en esa diligencia no se cometió ningún delito y se cesó todo procedimiento. 



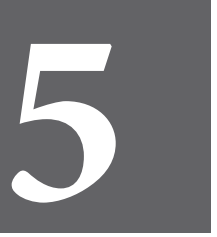

CAPÍTULO CINCO 



\title{
Gobernación militar y pacificación: el caso de Chinchiná (1953-1957)
}

\author{
Jhon Jaime Correa Ramírez $z^{398^{*}}$ \\ Wilton Holguín Rotavista ${ }^{399 *}$ \\ Anderson Andrés López Urrea ${ }^{400^{* * *}}$
}

La paz está dando a Chinchiná, una posición eminente en los destinos de Caldas que es menester conservar como el más alto patrimonio de civismo ${ }^{401}$.

Venimos de la noche política y vamos hacía el amanecer de la Patria ${ }^{402}$.

$398^{*}$ Doctor en Ciencias de la Educación de RUDECOLOMBIA, Magíster en Ciencia Política de la Universidad de Antioquia e Historiador de la Universidad Nacional de Colombia Sede Medellín. Profesor Titular de la Universidad Tecnológica de Pereira. Autor, entre otros libros, de: Civismo y educación en Pereira y Manizales (1925-1950) (2015) y Tinta Roja. Prensa política y educación en la República Liberal (1930-1946) (2016).

$399^{* *}$ Licenciado en Ciencias Sociales de la Universidad de Caldas. Estudiante de la Maestría en Historia de la Universidad Tecnológica de Pereira.

$400{ }^{* * *}$ Licenciado en Ciencias Sociales de la Universidad de Caldas. Es autor del libro Breve historia de Chinchiná. Una historia compartida desde las imágenes (2019).

401 Gustavo Sierra Ochoa, Una política: discursos y alocuciones de Gustavo Sierra Ochoa (Manizales: Imprenta Departamental, 1956), 251.

402 Fabricio Restrepo, «Discurso de Sierra Ochoa en Anserma», Revista Candilejas (1954): 2632. 
Alrededor dela violencia política del siglo xx sehan construido en los espacios locales un sinfín de historias que incluyen las hazañas de bandoleros con actuaciones similares al estilo Robin Hood $^{403}$; los desplazamientos de «Pájaros» conservadores, las leyendas urbanas de hombres con rezos especiales, y muchas descripciones de asesinatos violentos con técnicas terroríficas como el corte franela ${ }^{404} \mathrm{y}$ la ley de fuga ${ }^{405}$. Varias de estas anécdotas han sido parte de la historia política de la cual se habla en las monografías municipales, pero otras han quedado relegadas en la memoria de adultos mayores que cuentan, como historia de vida, su papel y sus acciones durante la época.

Preguntar por La Violencia en el contexto local, según Carlos Miguel Ortiz, es encontrar muchas historias producidas desde un enfoque partidista, con la marca de la censura moral y el lastre de aspectos intolerantes reflejados a través de un esquema binario del lenguaje $e^{406}$ en el que los discursos giran alrededor de los buenos y de los malos, de los azules y de los rojos, y de los pobres y de los ricos.

Este corpus de conocimiento empírico y oral, el cual se escucha en los cafés del Eje Cafetero, responde a la ausencia de una tradición archivística en la región que ha limitado el desarrollo de más estudios locales sobre La Violencia, los cuales respondan a las visiones y a las experiencias de los protagonistas. $\mathrm{Al}$ respecto, en la literatura existente sobre el tema, la cual trata la región en la que se ubica el actual municipio de Chinchiná, se encuentra el libro

403 Sánchez y Meertens, Bandoleros..., 18. Los autores relacionan las acciones del bandolerismo social con el mito inglés de Robin Hood. Sin embargo, las anécdotas locales no están fundamentadas en la categoría de «bandolerismo» con todas sus implicaciones, sino en la acción de quitarle a los ricos para darle a los pobres.

404 El corte franela comprometía la aorta en el paso por el cuello, una cortada allí hacía morir a la víctima lentamente. María Victoria Uribe Alarcón, Matar, rematar y contramatar Las masacres en La Violencia en el Tolima 1948-1964 (Bogotá: CINEP, 1990), 174.

405 La ley de fuga es una práctica que surgió durante la Guerra Civil Española, consistía en dar de baja a los adversarios capturados bajo afirmación de que el acusado había intentado fugarse. En América Latina está práctica fue común especialmente en Colombia y Argentina. Manuel Bravo Portillo, «La ley de fugas» Historia de Iberia Vieja, nº 86 (2012): 93.

406 Carlos Miguel Ortiz, «Los estudios sobre La Violencia en las tres últimas décadas», Boletín Socioeconómico, n. ${ }^{\circ}$ 24-25 (1992): 46-52. 
Estado y subversión en Colombia, publicado en 1986 por Carlos Miguel Ortiz. Este autor conjuga sucesos del orden nacional a la región y el desarrollo en la zona del Quindío para dar cuenta de las dinámicas estatales durante este periodo ${ }^{407}$.

En virtud de un contexto marcado por los debates historiográficos e ideológicos alrededor de la construcción de la paz, tal como los que se dieron durante la presente investigación debido a la firma del acuerdo entre las Farc-Ep y el Gobierno Nacional en cabeza de Juan Manuel Santos, y la insuficiente exploración a nivel local de estudios sobre el régimen político durante La Violencia en el departamento de Caldas; el objetivo de este capítulo es analizar las acciones cívicas de paz y algunas de sus consecuencias emprendidas durante el gobierno militar de Rojas Pinilla (1953-1957) en el municipio de Chinchiná, con el fin de apreciar el desarrollo e implementación de las políticas nacionales y regionales en materia de pacificación desde el ámbito local.

De esta manera, dicho capítulo es el resultado de un ejercicio de investigación formativa que permitió el acercamiento, de manera teórica y práctica, a las labores del oficio de hacer historia. En este proceso de aprendizaje, la aproximación a las pocas fuentes que se conservan en los municipios aportó a la construcción de una historia poco explorada desde los archivos locales, la cual se suscribe a las características de la «historia matria» propuesta por Luis González y González, en la que se reconoce la importancia de la historia familiar, del terruño, de la historia pueblerina y de la historia parroquial ${ }^{408}$.

\subsection{Coronel Gustavo Sierra Ochoa: «el ánimo pacificador» en Caldas}

El 13 de junio de 1953, ante la hostilidad de las mayorías liberales y de la unión de los ospinistas a la oposición, Laureano

407 Ortiz, «Los estudios sobre...», 46-52.

408 Luis González y González, Nueva invitación a la microhistoria (México: Fondo de Cultura Económica, 1982), 32. 
Gómez se convirtió en el tercer presidente depuesto por medio de un golpe de Estado $^{409}$. En medio de una profunda división del partido de gobierno y una situación de orden público aparentemente intolerable-, el general Gustavo Rojas Pinilla asumió el poder como «...el único que podría ponerle fin al derramamiento de sangre ${ }^{410}$.

El 14 de junio el periódico La Patria anunció «en una maratón informativa» ${ }^{411}$ que el país en menos de doce horas había tenido tres presidentes. El diario caldense adhirió su línea editorial al nuevo gobierno sin cuestionamiento alguno hacía la figura militar, porque este era respaldado por Mariano Ospina Pérez. En las páginas interiores del diario, la noticia era la aceptación de las «ideas conservadoras» que promulgaba Rojas Pinilla, postura que compartían los directorios conservadores de los municipios de Belén de Umbría, Anserma, La Celia, Santa Rosa de Cabal y Chinchiná, aquellos que se suscribieron públicamente por medio de telegramas enviados al medio.

Aunque era evidente la relación entre el nuevo Gobierno y los conservadores, los liberales de varios municipios del departamento $^{412}$ vieron en la figura militar la posibilidad de conseguir la paz que reclamaban. En un principio, Rojas Pinilla fue considerado un agente neutro dentro del conflicto, lo cual favoreció el inicio - en los primeros meses de su mandato- de un periodo de amnistías y desarme del movimiento armado especialmente en la zona de los Llanos Orientales-, por lo que el beneplácito de Rojas Pinilla se vio favorecido porque, a la par de

409 El conservador Laureano Gómez fue el tercer presidente depuesto desde la consagración de Colombia como Republica en la Constitución Política de 1886. Antonio Álvarez Restrepo, Los golpes de Estado en Colombia (New York: Nook Press, 2017).

410 David Bushnell, Colombia una nación..., 292.

411 La Patria [Manizales], 14 de junio de 1953: 1.

412 La idea de que Rojas Pinilla podía acabar con La Violencia y dar paso a procesos más democráticos también fue aceptada por los liberales de la región. Pedro Rojas Valencia militante del Partido Liberal escribió un documento testimonial titulado «Porqué la violencia», en este señala, desde un enfoque partidista, que los liberales del occidente de Caldas dieron visto bueno la posición militar del nuevo presidente. 
los procesos de amnistía, este generó políticas sociales, las cuales beneficiaron directamente las regiones del país.

Figura NRo. 32. Chinchiná, la ciudad luz de Colombia.

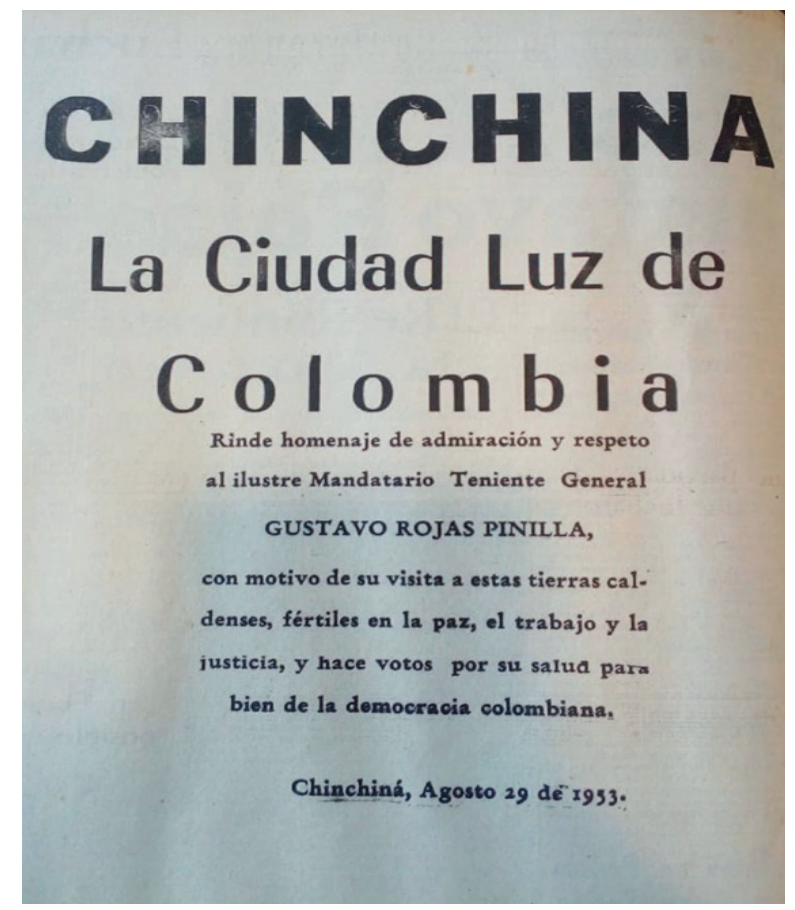

Fuente: La Patria [Manizales], 29 de agosto de 1953.

Con relación a las políticas sociales, el gravado constante a los diferentes sectores económicos permitió el financiamiento de los programas ofertados por la Secretaría Nacional de Asistencia Social (SENDAS) — creada en $1954^{413}$ - , lo cual se tradujo, para el caso de Chinchiná, en obras puntuales como la entrega de mercados y ropa, guarderías para niños, aguinaldos navideños para los más pobres, ayudas a madres y la construcción de casas de bienestar para los menos favorecidos ${ }^{414}$. La precariedad de la

413 Atehortúa, «El golpe de Rojas...», 33-48.

414 Concejo Municipal de Chinchiná, «Acta N²3 Junta Patriótica de Chinchiná» (Chinchiná: 1955). 
población a causa de La Violencia ofrecía grandes oportunidades para llevar a cabo los programas de intervención social de SENDAS $y$, a su vez, promover la figura del presidente «pacificador».

Los medios de comunicación cubrieron durante los primeros años «el apoyo popular» ${ }^{415}$ que obtuvo el Gobierno militar, a nivel regional, por el gran despliegue de las estrategias de pacificación en los territorios. Estas acciones fueron promovidas desde los medios locales como un avance significativo en la paz prometida por Rojas Pinilla. Varios factores priorizados por las Fuerzas Armadas como el despliegue de las operaciones militares en las zonas rurales le dieron fuerza al lema del régimen militar «Paz, Justicia y Libertad», lo cual generó que en las áreas urbanas la paz fuese discutida como un estado a punto ser alcanzado ${ }^{416}$.

En un escenario de aceptación de la gestión militar, por parte de diferentes medios de comunicación de la región, y la discusión periodística entre La Patria y El Diario ${ }^{417}$ debido a las consecuencias de La Violencia en el departamento se dio el nombramiento del primer gobernador militar para Caldas. El coronel Gustavo Sierra Ochoa quien reemplazó al abogado y politólogo Fernando Londoño Londoño ${ }^{418}$, el cual solo duró tres meses en el cargo.

El 24 de septiembre de 1953 se dio el nombramiento de Sierra Ochoa, asunto que fue celebrado en los medios locales, porque que, según el periódico de Anserma, Renovación - de tendencia conservadora-, la idea era nombrar un gobernador militar independiente de la clase política de Manizales. Por lo que decían:

415 La Patria [Manizales], 29 de agosto de 1953: 8.

416 Sánchez y Meertens, Bandoleros..., 29.

417 La Patria [Manizales], 1 de agosto de 1953: 4.

418 El nombramiento de Fernando Londoño Londoño se dio diez días después de la instalación del gobierno de Rojas Pinilla. Su filiación política era conservadora. La Patria [Manizales], 24 de junio de 1953: 6 . 
Cuando ciertos sectores de la opinión pública se dedicaron a pedir al gobernador militar para Caldas, se pensó en un oficial que por apellidos, orgullo y tradición estaba fuertemente aliado a la camarilla manizaleña que a control remoto trata de guiar al departamento todo. Pero en el dicho oficial pensaron algunos, menos los encargados de nombrar gobernadores. Ellos pensaron en el pundonoroso oficial Sierra Ochoa. Sierra Ochoa, a no dudarlo será el fiel exponente de la política del teniente general Rojas Pinilla. Estamos seguros de que obrará justamente sin entender al núcleo de oligarcas de Manizales ${ }^{419}$.

La figura de Sierra Ochoa en la prensa local se vio favorecida por su relación de colegaje con Rojas. Según la opinión pública, su condición de militar iba a facilitar la canalización de los lineamientos de «desarrollo y progreso» del Gobierno. De hecho, el mismo Sierra siempre aclaró ser «seguidor fiel de las políticas de paz, justicia y libertad $»^{420}$, promulgadas por este. En ese sentido, empezó a configurar discursos como el de la paz, el del restablecimiento del orden público y el de la promoción del desarrollo de los territorios para ponerle fin a las décadas violentas; las cuales habían tenido en vilo al país. Esto era entendido por la opinión pública como el ánimo pacificador, tal como se puede ver en el siguiente párrafo:

\begin{abstract}
$\mathrm{Al}$ arribar las fuerzas militares el 13 de junio del Capitolio, todos los colombianos miran hoy una brillante luz en el horizonte de la patria; en el alma popular se enarbola la fe más alta que nunca en los destinos de la nacionalidad, se afirma la esperanza en que vendrá necesariamente una transformación del orden político, una vigorosa modificación de las malas costumbres; un sano escrupuloso respeto a la ley, única ruta para el efectivo y rápido restablecimiento de la achacosa vida institucional de Colombia ${ }^{421}$.
\end{abstract}

419 Renovación [Anserma], 23 de septiembre de 1953: 3.

420 Gustavo Sierra Ochoa, Discursos y declaraciones [del señor gobernador de Caldas, coronel Gustavo Sierra Ochoa] 1953-1954 (Manizales: Imprenta Departamental Caldas, 1954), 6.

421 Gustavo Sierra Ochoa, Una política ..., 3 . 


\subsection{Acciones y cambios político-administrativos: creación de la Junta Patriótica Auxiliar y el «Consejo Administrativo» de Chinchiná}

Las gestiones y los cambios político-administrativos, promovidos por el Gobierno militar, se llevaron a cabo en el municipio de Chinchiná, en un periodo de inestabilidad política local ocasionado, entre otras razones, por el constante cambio de alcaldes ${ }^{422}$. En medio de este aparente desequilibrio, las élites locales comenzaron a figurar en el plano político porque su presencia permitía darle continuidad a las políticas nacionales y departamentales en el municipio y, a la vez, asegurar un conocimiento de las necesidades locales que ningún otro mandatario ofrecía.

Con la llegada del coronel Gustavo Sierra Ochoa al Palacio Amarillo, se hizo oficial la participación de estos grupos e individuos que servían de enlace entre el municipio, sus mandatarios y el departamento. Estas personas se vieron favorecidas por las reformas administrativas del ámbito nacional y departamental.

En las estrategias adaptadas por el Gobierno militar caldense para el municipio de Chinchiná se evidencian dos líneas de acción: una política que responde a las dinámicas nacionales, y una cívica y social para la gestión local. La participación de las élites fue fundamental y estratégica en la creación de dos cuerpos colegiados: el Consejo Administrativo Municipal y la Junta Auxiliar Patriótica.

El primero de estos respondió a las reformas políticas del Gobierno militar tras la cancelación de las elecciones nacionales. La figura de Consejo Administrativo fue reglamentada en el Acto

422 Entre 1953 y 1957 hubo cuatro mandatarios: 1953, Francisco García Vélez; 1954, Gerardo Londoño Vargas; 1955, Zabulón Marín Salazar; 1956, Educardo Arbeláez Salazar. Jesús Elías Pérez, Historia de Chinchiná Reminiscencias (Pereira: Papiro, 1996), 316. 
Legislativo nro. 2 de 1954, al expresarse:

A partir de la vigencia del presente Acto legislativo [sic], y hasta que puedan realizarse las elecciones correspondientes para Asambleas y Cabildos [sic], funcionarán en cada uno de los Departamentos [sic] y Municipios [sic] Consejos[sic] exclusivamente administrativos, que ejercerán, respectivamente, las funciones atribuidas por la Constitución y las leyes a las Asambleas Departamentales y a los Concejos Municipales ${ }^{423}$.

El segundo correspondió a la Junta Patriótica creada en 1953, mediante el Decreto 647 de la Gobernación de Caldas. Esta se definida como un órgano administrativo asesor de la alcaldía:

Proposición 3: La Junta Patriótica Auxiliar en su sesión inaugural, presenta un atento saludo a las autoridades Civiles [sic], y eclesiásticas de la Ciudad [sic] de Chinchiná, y les manifiesta su deseo de colaborar en todas y cada una de las obras que contribuyan al municipio ${ }^{424}$.

Estos organismos cívico-administrativos tuvieron como propósito la búsqueda de la paz. Las acciones y las obras fueron focalizadas y redirigidas hacia la intervención en la zona urbana del municipio donde se desarrollaba una violencia citadina, motorizada, ejecutada por sicarios y de finalidad marcadamente económica con pretexto de móviles políticos ${ }^{425}$. Para este momento las políticas de ampliación urbana fueron fundamentales en Chinchiná. En el informe del Departamento Técnico de la Seguridad Social Campesina para Caldas, direccionado por Ernesto Guhl, se señalaba lo siguiente desde 1954:

423 Concejo Municipal Chinchiná. «Acto legislativo $N^{\circ} 2$ de 1954». Asamblea Nacional Constituyente (Bogotá: Imprenta de la Nación, 1954).

424 Concejo Municipal Chinchiná, «Acta de instalación de la honorable Junta Patriótica de Chinchiná del 8 de Julio de 1955» (Chinchiná: 1955).

425 Campos, Fals y Umaña, La Violencia ..., 172 
Las reservas territoriales son, escasas, están siendo ocupadas rápidamente, y no representan una solución adecuada y definitiva para el problema espacial del campesino caldense; las posibilidades comerciales y portuarias de la Dorada, hoy por hoy el centro de mayor atracción demográfica, son limitadas y su saturación no tardará en presentarse, para continuar con un ritmo normal en su crecimiento, que no permitirá la absorción humana del momento; y la industrialización y el desenvolvimiento general y natural de ciudades como Manizales, Pereira, Armenia, y Santa Rosa de Cabal, no pueden asimilarse por ahora al crecimiento demográfico vegetativo del Departamento $[s i c] \mathrm{y}$, por lo mismo, no son suficientes para solucionar el problema económico-laboral de los excedentes campesinos ${ }^{426}$.

Es importante señalar que el municipio de Chinchiná presentó un crecimiento demográfico por encima de otros municipios del departamento ${ }^{427}$. Durante los años de La Violencia, entre 1951 y 1963, según el informe estadístico del DANE, la población urbana de Chinchiná pasó de 7577 a 15944 personas. Investigaciones locales han identificado esto como un desborde demográfico; el cual produjo violencia, informalidad y miseria ${ }^{428}$.

Para comprender las acciones e ideales cívico-militares dentro del funcionamiento de la Junta Patriótica Auxiliar, es necesario identificar los actores de la élite local chinchinense que hicieron parte de esta organización y, desde sus trayectorias de vida, construyeron las bases para las relaciones sociales que, en su mayoría, estuvieron enfocadas a construir confianza entre los mandatarios y el programa de gobierno con los procesos de trasformación y pacificación desarrollados en la época, a través de personas que eran reconocidas y validadas por la población del municipio.

426 Ernesto Guhl, Caldas: estudio de su situación geográfica, económica y social como base para el establecimiento de un régimen de seguridad nacional (Bogotá: Ministerio del Trabajo, 1956-1957), 189.

427 DANE, Monografía del municipio de Chinchiná (Manizales: Editorial Colorgráficas, 1991). http://biblioteca.dane.gov.co/media/libros/LD_5521_1991.PDF.

428 Anderson Andrés López Urrea, Breve historia de Chinchiná: una historia compartida desde las imágenes (Manizales: Manigraf Grupo Editorial GM SAS, 2019), 53. 
Entre los individuos integrantes de la Junta Patriótica Auxiliar de Chinchiná y el Consejo Administrativo se encontraban: médicos, comerciantes, maestros, hacendados cafeteros con avanzada formación intelectual —que iban más allá del promedio local-, lo cual permitía el desenvolvimiento en las acciones administrativas de índole público y privado, como también, unir esfuerzos con otros sectores estratégicos para continuar con el restablecimiento del orden público y el desarrollo de procesos de modernización.

Algunas de estas personas fueron Vicente Zapata Muñoz ${ }^{429}$, Luis Carlos Marín ${ }^{430}$, Elías Trujillo ${ }^{431}$, Rosendo León Gómez ${ }^{432}$, Alfredo Londoño ${ }^{433}$, Naún González Vargas, Santiago Marín Vargas, Nayib Jozame Taleb ${ }^{434}$, Fuad Jozame Taleb ${ }^{435}$ y Humberto

429 Vicente Zapata Muñoz fue elegido primer presidente de la Junta Patriótica Auxiliar de Chinchiná, fue un galeno quien trabajo para el Hospital San Marcos en el municipio del mismo municipio.

430 Luis Carlos Marín, recaudador de la Hacienda Nacional en el distrito de San Francisco de Paula (Chinchiná), entre 1914 a 1922, fue concejal de la localidad en 1921; personero de 1933 a 1935, nuevamente recaudador en 1950 y, otra vez, personero en 1963. También fue comerciante de víveres de primera necesidad e importante activista deportivo. Murió en Chinchiná a la edad de noventa y dos años en mayo de 1992. Pérez, Historia..., 230.

431 Elías Trujillo era oriundo de Palestina y tenía la profesión de carnicero. Importante comerciante de café y dueño de extensas tierras y propiedades campestres en Palestina. También fue dueño del Bar Pompeya y, además, jefe y concejal por el partido conservador en varias oportunidades en el municipio de Chinchiná. Dicho personaje era muy popular, apreciado y respetado por las gentes, dado que sobresalía en los campos del civismo. Pérez, Historia ..., 234.

432 Rosendo León Gómez se desempeñó como maestro en la Escuela General Francisco de Paula Santander, fue comerciante y pionero de las artes en el municipio de Chinchiná. Todo ello mientras era propietario del Teatro Municipal y, años más tarde, fundaba el teatro El Currumbay. Fue líder deportivo y fundador de La Cancha San Cristóbal - hoy plaza de mercado Chinchiná-. También se desempeñó como el primer presidente de la Sociedad de Mejoras Publicas de Chinchiná. Pérez, Historia ..., 241.

433 Alfredo Londoño fue un importante comerciante, productor y vendedor de café. Contaba con su propio depósito de grano y era dueño de los bares Chinchiná y El Rancho, la Heladería la Palma y Tipografía Chinchiná. De igual manera, era dueño y chalan de hermosas bestias finas y de una flota de camión, jeep y automóvil. Político que se desempeñó como concejal. Pérez, Historia..., 222.

434 Nayib ocupó altas y diferentes posiciones. En lo local fue concejal varios periodos y alcalde municipal cinco años, de 1969 a 1974. Se desempeñó como secretario de hacienda de Caldas, representante a la cámara, senador de la República, comerciante, urbanizador, cafetero, cívico, político y hombre de empresas varias. Pérez, Historia..., 219.

435 Fuad fue un ciudadano cívico, en toda la extensión de la palabra, y un hombre de empresa. Tuvo almacenes y el café Póker. Administro el Club Social local en sus dos etapas, cuando tenía el nombre Chinchiná y cuando se llamaba Monterrey. Fue concejal y dos veces personero municipal entre 1960 y 1974. Sobre todo, sobresalió como eminente ciudadano. Pérez, Historia..., 217 
Armel Ocampo ${ }^{436}$ - los últimos tres con descendencia siriolibanesa-.

La Junta Patriótica Auxiliar fue instalada formalmente el día 22 de julio de 1955 en el despacho de la alcaldía municipal de Chinchiná, tal como lo registra el acta de posesión de cargos. Adicionalmente, se resalta que en principio fueron parte de ella varios integrantes de la Sociedad de Mejoras Públicas de Chinchiná — la cual fue fundada el 3 de diciembre de 1953-.

El propósito principal trazado por dicha Junta fue la administración y ejecución de todo lo concerniente a las actividades sociales, cívicas, y de ornato que permitían tener un control, desarrollo y resguardo de las buenas prácticas. De esta manera, la Junta Patriótica Auxiliar de Chinchiná cumplió labores que a la fecha se desarrollaban las Sociedades de Mejoras Públicas en otras ciudades como Medellín, Manizales y Pereira.

Alrededor de las redes estratégicas de la Junta Patriótica Auxiliar de Chinchiná para el logro de sus objetivos, se incluyeron alianzas con sectores y comunidades religiosas entre las que se destacaban la Congregación de las Hermanas de la Divina Providencia y la Inmaculada Concepción de María — radicadas en Chinchiná desde el año de 1929 hasta el día de hoy-. Estas han sido pioneras en la educación del municipio con la Institución Educativa Santa Teresita. ${ }^{437}$

436 Humberto Armel Ocampo fue ese ciudadano epónimo el cual se desempeñó como personero municipal en 1953, tuvo una vinculación directa con la realización de las más hermosas procesiones de semana santa y la semana eucarística de Bodas de Oro en 1958, de la traída de Barcelona España, de la imagen del señor caído, las fiestas cívicas, los reinados, los flabelos, la fundación del Hotel San Francisco, la fundación de con la madre Matilde de la Cruzada Eucarística, el estadio 13 de junio, cuartel de bomberos, galería de mercado cubierto. Diseñó la bandera y escudo oficial del municipio de Chinchiná. Pérez, Historia ..., 189.

437 Institución Educativa Santa Teresita, «Un poco de historia», acceso el 15 de Noviembre de 2019, https://www.ie-santateresita.edu.co/un-poco-de-historia/. 
FigURA NRO. 33. Institución Educativa Santa Teresita Chinchiná 1950.

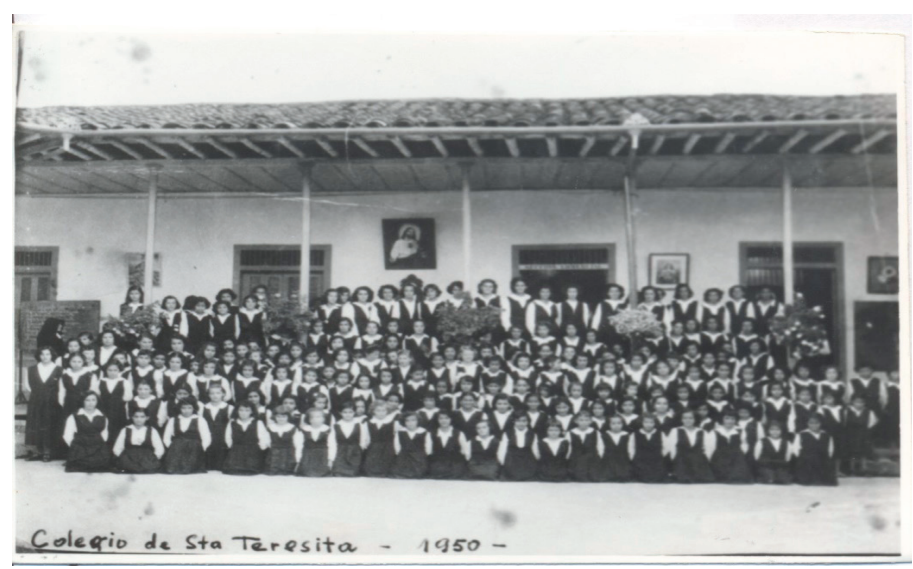

Fuente: Fotografía tomada del archivo de la Sociedad de Mejoras Públicas de Chinchiná.

Otra comunidad religiosa aliada fue la Congregación de las Hermanas Vicentinas, quienes se radicaron en Chinchiná el 27 de diciembre de 1947 con la fundación del Hospital San Marcos. Estas eran procedentes de la Casa General en Cali y se habían adherido al Gobierno militar bajo la administración de dicho hospital, principal centro de salud del Municipio de Chinchiná.

Entre las funciones realizadas por la Junta Patriótica estuvo la creación de campañas de recaudo de dinero y materiales de uso clínico que permitieran continuar con el buen funcionamiento del de este espacio hospitalario, el cual carecía de recursos frente al crecimiento exponencial de la población del municipio. Ante la situación comentada en medio de la sesión realizada el 20 de agosto de 1955 se tomaron disposiciones para suplir la necesidad del Hospital a través de acciones cívicas como la recolección de fondos, la solicitud de aportes por parte de la «Granja», hoy Cenicafé. 
Así, el Hospital San Marcos de Chinchiná inició una etapa de continuo progreso y modernización gracias a cada una de las campañas realizadas por las juntas de beneficencia. Los recursos recolectados se destinaron como lo indica el informe de la Junta Patriótica de la siguiente manera:

La construcción del Pabellón de pensionados, obra verificada el año pasado gracias al auxilio extraordinario dado por el actual gobierno [sic] departamental y en el cual tuvo su valiosa influencia el coronel Sierra Ochoa ${ }^{438}$.

Por otro lado, la Junta entendió la modernización, las comunicaciones y el ornato como los objetivos más importantes de su gestión. En el plano de estas segundas, se realizaron distintas reuniones con el único fin de unir esfuerzos para la instalación de un conmutador con quinientas líneas, misión que se configuró como prioritaria por varios meses. Con relación al último entendían, como lo indica Correa Ramírez en su libro sobre el civismo en el siglo $\mathrm{xx}$, que las calles, los parques, los edificios, los almacenes y las fachadas de las viviendas privadas constituían una especie de trípode sobre el que se podrían exhibir los cambios a nivel infraestructural de cada ciudad ${ }^{439}$. Por ello en un acta se decía:

Por su parte el señor presidente de la Corporación agrego que en esta ocasión se da la oportunidad de acordar al Dr. Bernardo Mejía Rivera, presente y nos ayude con su concurso en influencia ante el señor Administrador General [sic] de los Ferrocarriles [sic] nacionales, a fin de que sea concedido el permiso que en tantas ocasiones se le ha solicitado, para la construcción del parque RAFAEL REYES [sic], en los predios que actualmente posee aledaño a la estación de ferrocarril de la Ciudad $[\text { sic }]^{440}$.

438 Concejo Municipal Chinchiná, «Correspondencia del Hospital San Marcos enviada al consejo Administrativo de Chinchiná, 1 de septiembre de 1955» (Chinchiná, 1955).

439 Jhon Jaime Correa Ramírez, Civismo y educación...

440 Concejo Municipal Chinchiná, «Acta del 20 de agosto de 1955» (Chinchiná, 1955). 
Al pensar en la conexión regional, la Junta Patriótica de Chinchiná inició la construcción de redes de trabajo con las demás juntas del departamento para realizar campañas de ornato, religiosidad, campañas cívicas y sanidad con el fin de alcanzar el éxito de este nuevo proceso cívico militar. Así lo evidencia la correspondencia del 23 de julio de 1955, donde

La Junta Patriótica de la ciudad de Chinchiná, en su segunda sesión envía un atento y respetuoso saludo a las juntas patrióticas de los municipios del departamento y hace votos porque las labores a ellas encomendadas, sea benéfica en pro de la administración pública, que cada junta patriótica dignamente representa ${ }^{441}$.

Figura NRo. 34. Desfile del Colegio Bartolomé Mitre Chinchiná, años 50 .

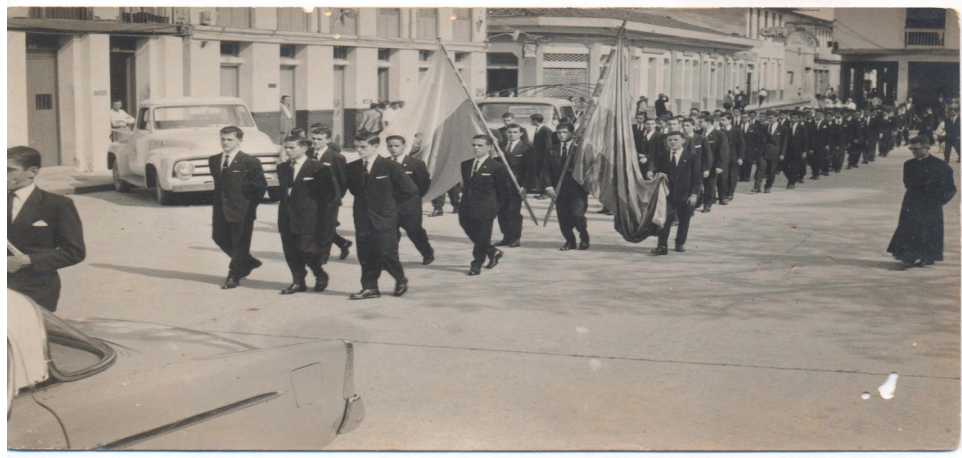

Fuente: Fotografía tomada del Archivo de la Sociedad de Mejoras Públicas de Chinchiná.

\subsection{Los consejos administrativos}

A la par del desempeño social, caritativo y cívico que realizaba la Junta Patriótica, el Consejo Administrativo de Chinchiná se ocupó de las acciones legales. Esta fue la corporación creada por el

441 Concejo Municipal Chinchiná, «Acta n. 2 de la Honorable Junta Patriótica Auxiliar de Chinchiná, Correspondiente al 23 de Julio de 1955» (Chinchiná, 1955). 
régimen militar como el remplazante de los concejos municipales cerrados en todo el país por orden del presidente Mariano Ospina Pérez en 1949. Lo anterior no significaba que las labores de la Junta Patriótica fuesen ilegales, sino que tenían un carácter más de tipo social, de mediación o de representación de los intereses locales cuya concreción debía pasar al terreno formal. Por su parte, las funciones realizadas por el Consejo Administrativo tenían que ver con todo lo concerniente a la ley. Fue una corporación, con una mayor responsabilidad, encargada de dar tránsito y financiación a las solicitudes realizadas por parte de la Junta Patriótica. Esta tenía las tareas ligadas al mantenimiento del orden, a la emisión de información oficial, a la realización del control fiscal, a la aprobación de presupuesto de funcionamiento, y al control y nombramiento de los funcionarios públicos solicitados por el gobierno local y departamental.

Dicha corporación tenía una constante comunicación con el gobernador militar Sierra Ochoa, quien -en últimas por su cargo - era la persona que debía aprobar cada una de las propuestas emitidas por el Consejo; todo ello a partir de decretos. Igualmente, el Consejo Administrativo controló los recursos para la ejecución de políticas sociales bajo el proyecto SENDAS en el que participaba, como actor protagónico, al lado de las instituciones cercanas a la Junta Patriótica Auxiliar de Chinchiná.

Pese a que el funcionamiento del Consejo Administrativo en Chinchiná empezó un año más tarde que el mandato de Sierra Ochoa, él ocupó mayor protagonismo dentro del ámbito oficial, pues tenía la potestad de administrar los recursos monetarios y bienes muebles del municipio, además de planificar la creación de cargos. De la misma forma, trabajó por la continua protección de los menos favorecidos en temas de educación. A la vez se caracterizó por las buenas relaciones con sectores obreros en el municipio y gestionar políticas que beneficiaran a los mismos y al lograr mayor apoyo al Gobierno militar. 
En las políticas educativas el Consejo Administrativo tuvo una constante y buena comunicación con los centros educativos del municipio de Chinchiná, tales como el colegio privado para mujeres, Institución Educativa Santa Teresita -bajo administración de las Hermanas de la Divina Providencia- como el recién creado colegio Bartolomé Mitre - bajo la rectoría del Sacerdote Santiago Marín Vargas-. El Consejo Administrativo no solo se preocupó por la educación básica de los pobladores de Chinchiná, también procuró conservar la enseñanza de las buenas costumbres, de las artes y del civismo como pilar fundamental de los procesos educativos de Chinchiná. Por lo tanto, cabe señalar que muchas de las políticas que permitieron la educación de la población fueron posible gracias a las becas o subsidios para «las niñas pobres», en el caso del colegio femenino, o la gestión de mayor número de recursos ante el gobierno departamental y el programa SENDAS.

Así, el Consejo Administrativo dentro de sus funciones tuvo el compromiso de realizar la planificación urbana del municipio, por ejemplo, en el año 1957 realizó varios procesos de planificación territorial al delimitar la zona de tolerancia llamada «El Morro»; lugar donde se encontraban la mayoría de los expendios de licor, lugares dedicados a los juegos de azar y lupanares o zonas de prostitución. Esta delimitación territorial se realizó ante las continuas solicitudes y quejas de los habitantes, las cuales expresaban:

... en el lugar donde está ubicada la zona de tolerancia hay hogares adyacentes de buen vivir y por lo tanto se hace preciso aislar un poco más tales corográficos. Que el municipio de Chinchiná está urbanizándose paulatinamente y el gobierno municipal está empeñado en limitar la zona que corresponde al barrio de tolerancia y así no afecte los barrios residenciales construidos o que posteriormente se construirán. Que, a partir del 6 de marzo de 1957, el lugar donde quedará ubicada la zona de tolerancia, la 
cual quedará delimitada en la siguiente forma: de la calle 1a hasta la calle $4 a$ entre carreras 4 a. $5 a$. 6a., de la nomenclatura actual ${ }^{442}$.

Otra de las responsabilidades del Consejo Administrativo giró alrededor de mantener una continua comunicación con las autoridades militares, eclesiásticas y civiles de la región. Seguidamente, fueron los encargados de elegir, idóneamente, el personal para diferentes cargos de importancia y responsabilidad como el personero municipal que, para el caso local de Chinchiná, fue nombrado en 1956 el célebre líder civil y fundador de la Sociedad de Mejoras Publicas, el señor Humberto Armel Ocampo.

Así, la comunicación encontrada en los archivos del Consejo Municipal de Chinchiná, respecto al programa SENDAS y su actuar, expresaba constantes mensajes de gratitud por las políticas sociales realizadas en este municipio cafetero. En ella decían:

De gran trascendencia ha sido para Nuestro Pueblo Colombiano, la sin par obra que SENDAS ha llevado a efecto en estos días de Navidad, al hacer un sin número de donativos con destino a todos los niños pobres de la Nación ${ }^{443}$.

No cabe duda que el programa «aguinaldo para el niño pobre» requería de grandes apoyos locales, regionales y nacionales. Por tal motivo, fue reiterativa la presencia de SENDAS como actor protagónico de la movilización social de la élite regional y local. Desde allí estos grupos locales construyeron un caudal político, ya que el mensaje de las personas con mayor capital económico era bien recibido por las clases menos favorecidas.

A lo largo de este capítulo se han intentado entender las dimensiones políticas del Gobierno militar desde una perspectiva local en el municipio de Chinchiná. Fueron abordadas dos instituciones que evidencian la actuación de dicho Gobierno

442 Concejo Municipal Chinchiná, «Acuerdo No. 001 de marzo 6 de 1957» (Chinchiná, 1957). 443 Concejo Municipal Chinchiná, «Correspondencia del Hospital San Marcos enviada al concejo Administrativo de Chinchiná, 1 de septiembre de 1955» (Chinchiná: 1955). 
a escala local. En este sentido, la Junta Patriótica Auxiliar y el Consejo Administrativo fueron protagonistas en el proceso de legitimación del régimen, al tiempo que fueron participes del control, vigilancia y buen uso de los recursos públicos entre 1953 y 1957. Ambas corporaciones tomaron parte en el proceso de modernización de Chinchiná con la realización de obras públicas como la pavimentación de la plaza principal y otras calles, la creación de un cuerpo de bomberos, la inauguración del estadio 13 de junio y la construcción de la plaza de mercado. 



\section{Epílogo}

Tras este diverso recorrido, a través de los diferentes capítulos, buscábamos aportar nuevos enfoques interpretativos que ayudarán a comprender el periodo de La Violencia en Colombia a una escala regional; específicamente, en el departamento de Caldas entre los años 1953 y 1964. Durante este lapso, dicha zona del país estuvo entre los lugares más afectados por el flagelo de la violencia liberal-conservadora, a la cual se intentó poner remedio con la llegada de los militares al poder ejecutivo - nombramiento de gobernadores y alcaldes militares- y con la intervención cívico-militar de las Fuerzas Armadas en diferentes localidades de la región.

Pese a las múltiples publicaciones que hay alrededor de los inicios de la violencia política, del periodo presidencial de Gustavo Rojas Pinilla y del Frente Nacional, teníamos la pretensión de escarbar en diferentes fondos documentales, los cuales permitieran establecer la forma en que los representantes del Ejército trataron por diversos medios $-\mathrm{y}$ muchas veces de manera infructuosa- 
pacificar la región, apaciguar las pasiones sectarias bipartidistas y contener el avance de las organizaciones de bandoleros y de las ideas comunistas.

En este sentido, se ha querido dar relevancia a una serie de hechos y medidas llevadas a cabo por los gobernadores militares designados desde el Gobierno de Rojas Pinilla. Dichas medidas se daban con el fin de retornar el control social y a la paz en una región, conocida a nivel nacional por la prosperidad de sus tierras cafeteras. Sin embargo, este territorio, a su vez, era escenario de hechos sangrientos y de enfrentamientos entre grupos armados ilegales con las Fuerzas Armadas.

Así mismo, a través de este estudio, ha sido posible vislumbrar el papel de la prensa en la configuración de relaciones entre los militares y los partidos políticos tradicionales. Estos y aquellos tuvieron momentos de auge y de tensión en el acelerado contexto político de esta época - tanto a nivel nacional como regional y local-; particularmente, en momentos como la llegada de Rojas Pinilla a la presidencia de la República, el establecimiento de la Asamblea Nacional Constituyente, la posterior salida de Rojas del poder y la imposición de una Junta Militar como medida transitoria para dar luego paso a la instauración del régimen político del Frente Nacional. Del mismo modo, es muy interesante ver la forma cómo los periódicos de circulación regional se constituían en un referente esencial para orientar el comportamiento político de los ciudadanos. No cabe duda que la prensa asumía una labor de tribuna pública que alimentaba el espíritu sectario con el cual se vivía la política en aquellos años. Esta situación era más notoria a partir del mutuo recelo existente entre la prensa de ciudades como Pereira (a través de las páginas de El Diario, el cual contaba con una gran filiación de seguidores del Partido Liberal) y Manizales (de talante conservador, que tenía en el periódico La Patria un gran bastión político e ideológico). 
A través del análisis de las publicaciones impresas se pudo resaltar la visión del primer gobernador militar de Caldas durante el periodo de estudio-, el coronel Gustavo Sierra Ochoa, quien asumió con mucho vigor y responsabilidad la tarea de pacificación que le fue encomendada directamente por Rojas Pinilla. Se destacó la aplicación de planes y estrategias clasificadas como acciones cívico-militares a través de las cuales el organismo castrense buscaba ganar una mayor confianza y legitimidad política entre los pobladores de la región mediante el desarrollo de distintos tipos de obras públicas como la creación de escuelas, puestos de salud, carreteras, entre otras. Bajo esta lógica, no fue extraño que los gobernadores militares trataran de proponer el denominado binomio Pueblo-Fuerzas Armadas, el cual sirvió de base al proyecto político de la «Tercera Fuerza Política» de Rojas, en una clara alusión a la generación de una nueva fuerza de corte popular que estuviera por encima de los partidos políticos Liberal y Conservador.

De esta manera, se logró evidenciar que el retorno a la democracia bajo la égida de los militares quedó en vilo. Por un lado, algunos miembros de la cúpula militar asumieron su labor de restauración del orden político, y de los ánimos sectarios de la población de manera mesiánica y redentora. De esta índole, propusieron un nuevo partido político de corte militar-populista muy a tono con los procesos populares que se llevaban a cabo en otras latitudes en América Latina (Juan Domingo Perón en Argentina, Manuel Odría en el Perú, Getúlio Vargas en Brasil, Marcos Pérez en Venezuela, entre otros). Además del recelo de los líderes de los partidos políticos tradicionales, ante el temor de que Rojas Pinilla se atornillara al poder, se sumaron las restricciones que se impusieron a la libertad de prensa. Esta situación le valió el calificativo de dictador desde distintos ámbitos de la opinión pública nacional. Así, al descrédito político, se vinculó el hecho de que en muchas regiones los agentes de las Fuerzas Armadas -y también de la Policía Nacional- se vieron inmersos en una cantidad de denuncias por atropellos, violaciones, abuso de fuerza 
y diferentes hechos de sangre que pusieron en cuestión el papel pacificador del Ejército. De igual modo, en el contexto de la Guerra Fría, era factible señalar que la dirigencia política de Colombia tomó partido por la causa norteamericana de contención del comunismo, lo cual derivó en que el ejercicio de pacificación de las poblaciones y zonas rurales se asumiera en términos de una lucha antiguerrillera o de guerra de guerrillas; factor determinante para que el Ejército quedara constituido en un elemento más del conflicto armado y social que vivía el país por aquellas décadas.

Dentro de los hallazgos que consideramos importantes para destacar, reiteramos la idea de una pacificación sin paz, la cual permite aseverar que la calma y el retorno de la democracia se dieron con un entramado de intereses, conflictos y prevenciones que legitimaban posturas autoritarias como el cierre de órganos legislativos y de control político, además de las declaratorias de estado de sitio y restricciones a la libertad de prensa bajo la pretensión de salvaguardar el orden público y la democracia. Si bien se hace referencia a ciertas medidas como amnistías, desarmes, programas de rehabilitación de zonas afectadas por La Violencia y las acciones cívico-militares con las que el gobierno de Rojas Pinilla pretendió acabar con la violencia partidista; es claro que la paz no retornó, que muchas personas tuvieron que huir a causa del accionar de los miembros de organizaciones armadas - legales e ilegales - y que la añorada democracia quedó endosada durante dieciséis años a nombre del Partido Liberal y del Partido Conservador - con serias exclusiones a nivel político e ideológico-, lo cual dio lugar a un fuerte sentimiento de malestar e insurrección política. Si bien se logró dar de baja por parte del Ejército a algunos de los principales cabecillas de las cuadrillas de bandoleros, a través de diversos estudios se ha demostrado la transformación de estas en las bases de organizaciones guerrilleras de orientación marxista. 
Otra conclusión importante de este texto gira alrededor del cuerpo castrense y la transformación de la doctrina de la Fuerzas Armadas experimentada, durante este periodo, bajo la influencia de la doctrina de seguridad nacional de los Estados Unidos y la formación de oficiales colombianos en el exterior. Esto les permitió tener una mayor autonomía en el manejo del orden público del país, frente al poder civil, pese a su posterior salida del poder ejecutivo. A lo largo de estas dos décadas estudiadas, ocurrió una transformación radical en la que el Ejército acumuló una experiencia de combate físico y de acciones cívico-militares, las cuales prepararon para combatir, a partir de los años sesenta, las guerrillas de corte marxista. El departamento de Caldas se convirtió en un escenario para aplicar la nueva doctrina militar. Resultado de ello, convergieron, por ejemplo, la experiencia de lucha antiguerrillera en los Llanos Orientales que el coronel Sierra Ochoa sistematizó y aplicó como gobernador del departamento; la creación de la VIII Brigada para luchar contra las cuadrillas de bandoleros y el apoyo logístico y militar para la formación de grupos de autodefensa campesina.

Reconocemos que, al igual que en el desarrollo de las pesquisas, en el proceso de sistematización, clasificación y análisis de las fuentes quedó un amplio material de consulta por abordar, el cual nos hubiera permitido atar con mayor claridad una serie de cabos sueltos y sobre los cuales esperamos plantear futuras investigaciones.

Tiene pleno sentido, entonces, la preocupación por revisitar al pasado con el fin de darle una nueva lectura desde un presente en el que aún se reiteran las negaciones, las polarizaciones y las distorsiones en torno a las causas y los efectos de la violencia, en medio de una incesante fuga de la paz. Aunque quedan una diversidad de temas pendientes como estudiar las Fuerzas Militares - en una perspectiva comparada con otras regiones y en este mismo periodo de estudio-, los procesos electorales, los movimientos estudiantiles, la presencia de las organizaciones de 
izquierda en la región, la violencia en el occidente caldense - que fue tan intensa y cruda como en la zona del Quindío-, los diversos tintes de la cultura política bipartidista y sus múltiples facciones, el papel del clero - tanto en su participación en la violencia como en los procesos de amnistía y paz regionales-, el programa de rehabilitación en los años cincuenta y sesenta, y del papel de los jueces en este mismo periodo; consideramos que hemos logrado hacer un significativo aporte al conocimiento histórico de este periodo y de esta región, sobre la cual aún se desconocen muchos trasfondos históricos. Sin duda, es un referente clave en la comprensión de ciertas dinámicas políticas regionales que, en el contexto actual, cobran plena vigencia y pertinencia para entender los inicios de los procesos de violencia y las propuestas de paz que lamentablemente han quedado en el camino y han sido casi olvidadas por parte de muchas generaciones en el presente. 


\section{Referencias bibliográficas}

Fuentes primarias

\section{Archivos}

Archivo General de la Nación.

Biblioteca Nacional.

Alcaldía Municipal de Pereira.

Alcaldía Municipal de Chinchiná.

Alcaldía Municipal de Neira.

Alcaldía Municipal de Anserma.

Archivo Judicial de Anserma.

Archivo Gobernación de Caldas.

Archivo Histórico de Manizales.

Archivo de la Sociedad de Mejoras Públicas de Chinchiná.

Concejo Municipal de Chinchiná.

Hemeroteca Biblioteca Municipal de Pereira Ramón Correa Mejía.

Hemeroteca Área Cultural Banco República-Armenia.

Hemeroteca Área Cultural Banco República-Manizales.

Hemeroteca Área Cultural Banco República-Pereira. 


\section{Publicaciones periódicas}

Diario Oficial República de Colombia. Bogotá. 1913-1964.

El Binomio. Fuerzas Armadas-Pueblo. Calarcá. 1956.

El Diario. Pereira. 1929-1957.

El Diario del Quindío. Armenia. 1928-1954.

El Tiempo. Bogotá. 1954-1955.

La Patria. Manizales. 1921-1967.

Renovación. Anserma. 1953.

Revista Estadística de Criminalidad. Bogotá. 1965.

Revista Criminalidad. Bogotá. 1959-1964.

Revista Sábado. Bogotá. 1953.

\section{Documentos impresos}

Alcaldía Municipal Belalcázar. Sumario Penal. Delito de la asociación e instigación para delinquir. Sindicados Alejandro Sotelo, Gonzalo Torres y otros. Ofendida la sociedad. Belalcázar: Archivo Judicial Anserma, 1958.

Boletín Arquidiocesano. Tomo XXI, n. ${ }^{\circ}$ 240. Manizales, noviembre de 1958.

Departamento Administrativo Nacional de Estadística (DANE). Censo nacional de población 1951. Caldas. Bogotá: DANE, 1951. 
. XIII Censo de población y II de edificios y viviendas. Julio 15 1964. Caldas. Bogotá: DANE, 1964.

- Monografía del municipio de Chinchiná. Manizales: Editorial Colorgráficas, 1991.

Contraloría General de la República. Censo general de la población 1938, departamento de Caldas. Bogotá: Editorial Minerva, 1941.

Fuerzas Armadas de Colombia. Estudio criminológico. Bogotá: Ministerio de Guerra, 1958.

Ministerio del Trabajo. Caldas. Memoria explicativa del «Atlas» socio-económico del departamento. Bogotá: Ministerio del Trabajo, 1956.

Policía Nacional. "Análisis general situación orden públicoCaldas». Revista Criminalidad, n. ${ }^{\circ} 1$ (1958): 14-27.

Presidencia de la República. «Decreto 328 de 1958 (noviembre 28) por el cual se dictan unas disposiciones tendientes a facilitar el afianzamiento de la paz en los Departamentos en donde subsiste el estado de sitio». Bogotá: Imprenta Nacional, 1958.

Teniente Coronel Cayo Eduardo Jiménez Mendoza. «Autodefensa». Revista de las Fuerzas Armadas XII. n. ${ }^{\circ} 35$. Bogotá: Noviembre y diciembre, 1965. 


\section{Fuentes Secundarias}

\section{Libros}

Acevedo, Álvaro y Jhon Jaime Correa. Tinta Roja: Prensa, política y educación en la República Liberal (1930-1946). El Diario de Pereira y Vanguardia Liberal de Bucaramanga. Bucaramanga: UIS-UTP-Colciencias, 2016.

Alape, Arturo. Las muertes de Tirofijo. Bogotá: Ediciones Abejón Mono, 1972.

Las vidas de Pedro Antonio Marín Vélez Tirofijo. Bogotá: Editorial Planeta, 1989.

. Tirofijo: Los sueños y las montañas 1964-1984. Bogotá: Editorial Planeta, 2002.

Álvarez Restrepo, Antonio. Los golpes de Estado en Colombia. New York: Nook Press, 2017.

Arenas, Jасово. Diario de la resistencia de Marquetalia. Bogotá: Ediciones Izquierda Viva, 2015.

Arocha, Jaime. La Violencia en el Quindío. Determinantes ecológicos y económicos del homicidio en un municipio caficultor. Bogotá: Ediciones Tercer Mundo, 1979.

Belmonte, Pedro Luis. Antecedentes históricos de los sucesos del 8 y 9 de junio de 1954. Bogotá: Imprenta Nacional, 1954.

Buitrago Salazar, Evelio. Zarpazo. Otra cara de la violencia. Bogotá: Fuerzas Militares, 1967. 
Bushnell, David. Colombia, una nación a pesar de sí misma. De los tiempos precolombinos a nuestros días. Bogotá: Editorial Planeta, 1994.

Camacho Arango, Carlos. El conflicto de Leticia (1932-1933) y los ejércitos de Perú y Colombia. Bogotá: Universidad Externado de Colombia, 2016.

Christie, Keith H. Oligarcas, campesinos y política en Colombia: aspectos de la historia sociopolítica de la frontera antioqueña. Bogotá: Universidad Nacional de Colombia, 1986.

Correa Peraza, Hernando. Los rostros de la violencia. Colombia 1930-1958. Historias para refrescar la memoria de los liberales y los conservadores. Bogotá: Universidad Sergio Arboleda, 2009.

Delgado Madroñero, Johnny. El bandolerismo en el Valle del Cauca, 1946-1966. Cali: Secretaría Cultura Valle del Cauca, 2011. http://cvisaacs.univalle.edu.co/cav/images/ Convocatorias/2010_2011/El_Bandolerismo_en_el_Valle_ del_Cauca_1946-1966_Libro.pdf.

Escobar, Arturo. La invención del desarrollo, Traducido por Diana Ochoa, 2. ${ }^{\text {a }}$ edición. Popayán: Universidad del Cauca.

Gallón Giraldo, Gustavo. La república de las armas. Relaciones entre Fuerzas Armadas y Estado en Colombia, 1960-1980. Bogotá: Centro de Investigación y Educación Popular, 1983. https://www.coljuristas.org/documentos/libros_e_informes/ la_republica_de_las_armas.pdf.

García Nossa, Antonio. Geografía económica de Caldas. Bogotá: Banco de la República, 1978. 
GONZÁLEZ y GoNZÁLEZ, LuIs. Nueva invitación a la microhistoria. México: Fondo de Cultura Económica, 1982.

Guillén Martínez, Fernando. El poder político en Colombia. Bogotá: Ariel, 2015.

Guhl, ERnesto. Caldas: estudio de su situación geográfica, económica y social como base para el establecimiento de un régimen de seguridad nacional. Bogotá: Ministerio del Trabajo, 1956.

Guzmán Campos, Germán; Orlando Fals Borda y Eduardo Umaña Luna. La Violencia en Colombia (Tomo I). Bogotá: Prisa Ediciones, 2012.

Hartlyn, Jonathan. La política del régimen de coalición. La experiencia del Frente Nacional en Colombia. Bogotá: Tercer Mundo Editores, 1993.

Henao, Jesús María y Gerardo Arrubla. Historia de Colombia. Bogotá: Librería Colombiana, 1936.

Henderson, James D. La modernización en Colombia. Los años de Laureano Gómez, 1889-1965. Medellín: Universidad de Antioquia, 2006.

Hobsbawm, Eric. Bandidos. Barcelona: Crítica, 2001. . Rebeldes primitivos. Barcelona: Ariel, 1983.

Jiménez Tobón, Gerardo. Gobernantes de Caldas 1905-1955. Manizales: Imprenta Departamental de Caldas, 1955.

Karl, Robert. La paz olvidada. Bogotá: Editorial Nomos S.A, 2018. 
Landazábal Reyes, Fernando. La subversión y el conflicto social. Bogotá: Tercer Mundo Editores, 1980.

Leal Buitrago, Francisco. Estado y política en Colombia. Bogotá: Siglo Xxi Editores, 1989.

LeGrand, Catherine. Colonización y protesta campesina en Colombia (1850-1950). Bogotá: Ediciones UniandesUniversidad de Los Andes, 2016.

Londoño, Julio. Nación en crisis. Bogotá: Ministerio de Educación Nacional, 1955.

Londoño, Rocío. Juan de la Cruz Varela. Sociedad y política en la región de Sumapaz (1902-1984). Bogotá: Universidad Nacional de Colombia, 2014.

López Urrea, Anderson Andrés. Breve historia de Chinchiná: una historia compartida desde las imágenes. Manizales: Manigraf Grupo Editorial GM SAS, 2019.

Marx, Karl. El dieciocho brumario de Luis Bonaparte. Moscú: Editorial Progreso, 1981.

Maullin, Richard. Soldiers, Guerrillas and Politics in Colombia. Lexington: Lexington Books, 1973.

Medina Gallego, Carlos. 8 y 9 de junio. «Día del estudiante»: crónicas de violencia, 1929 y 1954. Bogotá: Ediciones Alguimia, 2004.

Melo, Jorge Orlando. Historia mínima de Colombia. Bogotá: El Colegio de México, 2018.

Oquist, Paul. Violence, Conflict and Politics. Bogotá: Universidad de los Andes, 1976. 
- Violencia, conflicto y política en Colombia. Bogotá:

Banco Popular, 1978.

Ortiz, Carlos Miguel, Estado y subversión. La Violencia en el Quindío años 50. Bogotá: Fondo Editorial Cerec, 1985.

Ortiz Mesa, Luis Javier; Lina Marcela González Gómez y Oscar Almario García. Caldas, una región antigua y nueva, tradicional y moderna, local y nacional. Hacia un nuevo siglo XIX del noroccidente colombiano. Balance bibliográfico de Antioquia, Caldas y Chocó, Tomo 2. Medellín: Universidad Nacional de Colombia, 2015.

Palacios, Marco. Violencia pública en Colombia, 1958-2010. Bogotá: Fondo de Cultura Económica, 2012.

Entre la legitimidad y la violencia: Colombia 1975-1994. Bogotá: Editorial Norma, 1995.

Pardo Motta, Diego Nicolás. Laureano Gómez Castro y su proyecto de reforma constitucional (1951-1953). Bogotá: Universidad del Rosario, 2008. https://repository. urosario.edu.co/bitstream/handle/10336/12971/ Laureano\%20G\%c3\%b3mez\%20y\%20su\%20proyecto. pdf? sequence $=1$ \&isAllowed $=y$.

PÉCAut, Daniel. Orden y violencia. Evolución sociopolítica de Colombia entre 1930 y 1953 Bogotá: Editorial Norma, 2001. Crónica de dos décadas de política colombiana 1968-1988. Bogotá: Siglo xxi Editores, 1988.

Pérez, Jesús Elías. Historia de Chinchiná Reminiscencias. Pereira: Papiro, 1996. 
Pettinà, Vanni. Historia mínima de la Guerra Fría en América Latina. México: Colegio de México, 2018.

Quiroz Otero, Ciro. La Universidad Nacional en sus pasillos, y fuera de ellos, 2. a edición. Bogotá: Universidad Nacional de Colombia, 2018.

Ramírez Bacca, Renzo. Apuntes sobre historia socio-política y económica de América Latina en el siglo Xx. Pereira: Editorial Universidad Tecnológica de Pereira, 2020.

Ramírez Herrera, Walter y Martha Cecilia Jiménez Perafán. Marquetalia. La Violencia en provincia. 1946-1965. Cali: Imprenta Departamental del Valle del Cauca, 2002.

Ramsey, Russell Wilcox. Guerrilleros y soldados. Bogotá: Ediciones Tercer Mundo, 1981.

Rodríguez Ávila, Sandra Patricia. Memoria y olvido: usos públicos del pasado en Colombia, 1930-1960. Bogotá: Editorial Universidad del Rosario, 2017.

Roll, David. Inestabilidad y continuismo en la dinámica del cambio político en Colombia. Bogotá: ICFES, 1999.

Ruiz Montealegre, Manuel. Sueños y realidades: Procesos de organización estudiantil 1954-1966. Bogotá: Universidad Nacional de Colombia, 2002.

Ruiz Novoa, Alberto. El gran desafío. Bogotá: Ediciones Tercer Mundo, 1965.

. El batallón Colombia en Corea 1951-1954. Bogotá: Empresa Nacional de Comunicaciones, 1956. 
. Enseñanzas de la campaña de Corea aplicables al Ejército de Colombia. Bogotá: Editorial Antares, 1956.

Rouquié, Alain. El Estado militar en América Latina. México: Siglo XXI Editores, 1984.

Sáenz Rovner, Eduardo. Colombia años 50: industriales, política y diplomacia. Bogotá: Universidad Nacional Colombia, 2002.

Sánchez, Gonzalo y Donny Meertens. Bandoleros, gamonales y campesinos, el caso de la Violencia en Colombia. Bogotá: El Áncora Editores, 1985.

Sierra Ochoa, Gustavo. Caldas trabaja. Por la patria, la paz y la justicia. Manizales: Imprenta Departamental, 1954.

- Una política: discursos y alocuciones de Gustavo Sierra Ochoa. Manizales: Imprenta Departamental, 1956.

. Discursos y declaraciones [del señor gobernador de Caldas, coronel Gustavo Sierra Ochoa] 1953-1954. Manizales: Imprenta Departamental Caldas, 1954.

Silva, Renán. Prensa y revolución a finales del siglo XVIII. Contribución a un análisis de la formación de la ideología de independencia nacional. Medellín: La Carreta, 2004.

Torres del Río, Cesar Miguel. Colombia siglo xx. Desde la guerra de los mil días hasta la elección de Álvaro Uribe. Bogotá: Pontificia Universidad Javeriana, 2015.

Trujillo, Ciro. Ciro: Páginas de su vida. Bogotá: Ediciones Izquierda Viva, 2015. 
Ugarriza, Juan Esteban y Nathalie Pabón Ayala. Militares y guerrillas. La memoria histórica del conflicto armado en Colombia desde los archivos militares, 1958-2016. Bogotá: Editorial Universidad del Rosario, 2017.

Urdaneta Arbeláez, Roberto. El materialismo contra la dignidad del hombre. Su impacto en la vida colombiana. Bogotá: Editorial Lucros, 1960.

Uribe Alarcón, María Victoria. Matar, rematar y contramatar. Las masacres de La Violencia en el Tolima 1948-1964. Bogotá: Centro de Investigación y Educación Popular (CINEP), 1990. https://criticalatinoamericana.files.wordpress.com/2012/02/ matar-rematar-contramatar1.pdf.

Valencia Tovar, Álvaro. El final de Camilo. Bogotá: Ediciones Tercer Mundo, 1976. . Testimonio de una época. Bogotá: Planeta, 1992.

VIII BRIgAdA. De la violencia a la paz: experiencias de la Octava Brigada en la lucha contra guerrillas. Manizales: Imprenta Departamental de Caldas, 1965.

Villamizar, Darío. Las guerrillas en Colombia. Una historia desde los orígenes hasta los confines. Bogotá: Debate, 2017.

Villanueva Martínez, Orlando. Guerrilleros y bandidos. Alias y apodos de la violencia en Colombia. Bogotá: Fondo de publicaciones de la Universidad Distrital, 2007.

. Guadalupe Salcedo y la insurrección llanera, 1949-1957. Bogotá: Universidad Nacional Colombia, 2012. 


\section{Capítulos de libro}

Braun, Herbert, «De palabras y entendimientos del comportamiento cotidiano entre los colombianos durante la Violencia de los años cincuenta». En La restauración conservadora 1946-1957, ed. por Rubén SierRa Mejía, 1178. Bogotá: Universidad Nacional de Colombia, 2012.

Correa Ramírez, Jhon Jaime, «La otra Pereira. Migraciones, desborde popular, historia barrial e inclusión». En De la aldea a la ciudad. Personajes y hechos que forjaron a Pereira, ed. por El Diario, 98-115. Pereira: El Diario, 2019.

Correa Ramírez, Jhon Jaime; y Natalia Agudelo Castañeda y Edwin Mauricio López García. «Botas para salvar la democracia en la Gobernación de Caldas 1953-1967». En Apropiación social del conocimiento investigación, innovación y extensión en 2019. Vicerrectoría de Investigaciones, Innovación y Extensión, 343-360. Pereira: Universidad Tecnológica de Pereira, 2019.

Estévez Pedraza, Lucia, «Marquetalia: El mito fundacional de las Farc y la construcción del enemigo a través de la prensa». En La Prensa: un actor sempiterno. De la Primera Guerra Mundial a la Posmodernidad, coord. por Rosa MARÍA VALLEZ Ruíz, Rosa María González y Patricia Vega Jiménez, 227254. México: Universidad Autónoma del Estado de Hidalgo, 2014.

Gilhodes, Pierre, «El Ejército colombiano analiza la Violencia.» En Pasado y presente de la Violencia en Colombia, compilado por Gonzalo SÁnchez y Ricardo Peñaranda, 344-371. Bogotá: CEREC-IEPRI, 1995. 
Hobsbawm, ERIC, «La anatomía de La Violencia en Colombia». En Eric Hobsbawm sobre América Latina ;Viva la revolución!, ed. por Leslie Bethell, 263-273. Bogotá: Crítica, 2018.

Medina, Medófilo, «Historiografía colombiana y latinoamericana Vol. II». En La historia al final del milenio. Ensayos de historiografía colombiana y latinoamericana, compilado por Bernardo Tovar Zambrano, 433-483. Bogotá: Editorial Universidad Nacional de Colombia, 1994.

Sierra MejÍA, Rubén, «La lectura conservadora de Bolívar». En La restauración conservadora, ed. por RuBÉN SIERRA MeJíA, 69-104. Bogotá: Universidad Nacional de Colombia, 2012.

Silva Luján, Gabriel, «El origen del Frente Nacional y el gobierno de la Junta Militar». En Nueva historia de Colombia, ed. por Jorge Orlando Melo, 179-210. Bogotá: Editorial Planeta, 2001.

Tirado Mejía, Álvaro, «El gobierno de Laureano Gómez. De la dictadura civil a la militar». En Nueva historia de Colombia (Tomo. II), ed. por Jorge Orlando Melo, 81-104. Bogotá: Editorial Planeta, 2001. , «Rojas Pinilla: de golpe de opinión a exilio». En La Nueva historia de Colombia (Tomo II: Historia política 1946-1986), ed. por Álvaro Tirado Mejía, 105-126. Bogotá: Editorial Planeta, 1989.

Ventrone, Angelo, «El enemigo interno. Perspectivas historiográficas y metodológicas». En Historia cultural de la política contemporánea, ed. por JoRdi CANAL y JAVIER Moreno Luzón, 243-267. Madrid: Centro de Estudios Políticos y Constitucionales, 2009. 


\section{Artículos de revista}

Acevedo Tarazona, Álvaro. «El símbolo de un Robín Hood vengador en el occidente de Colombia». Estudios Humanísticos. Historia n. 3 (2004): 45-66.

Acevedo Tarazona, Álvaro y Jhon Jaime Correa. «Empresa, civilización y política: representaciones sobre el oficio periodístico en El Diario de Pereira y Vanguardia Liberal de Bucaramanga durante la República Liberal». Historelo Revista de Historia Regional y Local 5, n. 9 (2013): 206-243.

Acevedo Tarazona, Álvaro y Juliana Villabona. «Prensa y violencia. El deber y el conservatismo en Santander (19301946)». Justicia Juris 12, n. ${ }^{\circ} 1$ (2016): 86-99. http://www. scielo.org.co/pdf/jusju/v12n1/v12n1a08.pdf.

Acuña Rodríguez, Olga Yanet. "Censura de prensa en Colombia, 1949-1957». Historia Caribe 8, n.o 23 (2013): 241267. http://www.scielo.org.co/pdf/hisca/v8n23/v8n23a09. pdf.

Atehortúa Cruz, Adolfo León. "Los estudios acerca de las fuerzas armadas en Colombia: balance y desafíos.» Análisis Político n. ${ }^{\circ} 51$ (2004): 12-24. https://revistas.unal.edu.co/ index.php/anpol/article/view/80401/71103.

. «El golpe de Rojas y el poder de los militares». Folios n. ${ }^{\circ}$ 31 (2010): 33-48. http://www.scielo.org.co/pdf/folios/n31/ n31a03.pdf.

Bedoya Sánchez, Gustavo Adolfo. «La prensa como objeto de investigación para un estudio histórico de la literatura colombiana. Balance historiográfico y establecimiento del corpus». Estudios de Literatura Colombiana, n. ${ }^{\circ} 28$ (2011): 89-109. https://revistas.udea.edu.co/index.php/elc/article/ view/10935/10010. 
Beltrán Villegas, Miguel Ángel. «La Federación de Estudiantes Colombianos (FEC) y las luchas universitarias bajo la dictadura del general Gustavo Rojas Pinilla». Cardinallis, n. ${ }^{\circ} 10$ (2018): 16-40. https://revistas.unc.edu.ar/ index.php/cardi/article/view/20659/20310.

Betancourt, Darío. «Las cuadrillas bandoleras del Norte del Valle, en la violencia de los años cincuenta», Historia Crítica n. ${ }^{\circ} 4$ (1990): 57-68. https://doi.org/10.7440/histcrit4.1990.03.

Bravo, Manuel. «La ley de fugas», Historia de Iberia Vieja n ${ }^{\circ} 86$ (2012): 93.

Cajas Sarria, Mario Alberto. «La Corte Suprema de Justicia bajo el gobierno del general Gustavo Rojas Pinilla». Revista de Estudios Sociales, n. ${ }^{\circ} 50$ (2014): 127-139. https://journals. openedition.org/revestudsoc/8691.

Correa Ramírez, Jhon Jaime. Civismo y educación en Pereira y Manizales (1925-1950): análisis comparativo entre sus sociabilidades, visiones de ciudad y cultura cívica. Pereira: Universidad Tecnológica de Pereira, 2014.

Díaz Jaramillo, José Abelardo. «El 8 de junio y las disputas por la memoria 1929-1954». Historia y Sociedad n. 22 (2012):157-189. https://revistas.unal.edu.co/index.php/ hisysoc/article/view/32366/32378.

Gil Pérez, Anderson PAul. «Miradas historiográficas a la relación prensa e historia en el caso de Pereira». Ciencia Nueva Revista de Historia y Política 2, n. ${ }^{\circ} 1$ (2018): 134-152. https://doi.org/10.22517/25392662.15911. 
Henao Holguín, Diana. «Bandolerismo rural en el Bajo Cauca, Magdalena Medio y el Nordeste antioqueño (Colombia), 1953-1958». Historelo Revista de Historia Regional y Local 7, n. ${ }^{\circ} 14$ (2015): 300-301.

Jiménez Becerra, Absalón. "Una mirada al movimiento estudiantil colombiano. 1954-1978». Boletín Cultural $y$ Bibliográfico 51, n. ${ }^{\circ} 93$ (2017): 5-21. https://publicaciones. banrepcultural.org/index.php/boletin_cultural/article/ view/9523/9919.

Kircher, Mirta. «La prensa escrita: actor social y político, espacio de producción cultural y fuente de información histórica». Revista de Historia, n. ${ }^{\circ} 10$ (2005): 115-122. http:// revele.uncoma.edu.ar/htdoc/revele/index.php/historia/ article/view/219/210.

Leal Buitrago, Francisco. «Política e intervención militar en Colombia». Revista Mexicana de Sociología 32, n. ${ }^{\circ} 3$ (1970): 491-538. http://dx.doi.org/10.22201/ iis.01882503p.1970.3.58195.

. «Una visión de la seguridad en Colombia». Análisis Político, n. ${ }^{\circ} 73$ (2011): 3-36. https://revistas.unal.edu.co/ index.php/anpol/article/view/43704/44974.

Legrand, CATHERINE. «De las tierras públicas a las propiedades privadas: acaparamiento de tierras y conflicto agrarios en Colombia. 1870-1936». Lecturas de Economía, n. ${ }^{\circ} 13$ (1984): 14-50. https://doi.org/10.17533/udea.le.n0a18553.

López García, Edwin Mauricio y Jhon Jaime Correa. «Historia de una ley: Ley 70 de diciembre 1 de 1966, "por la cual se crea el departamento de Risaralda"». Reflexión Política 22, n. 44 (2020): 40-53. https://doi.org/10.29375/01240781.3806. 
López Pacheco, Jairo Antonio y Jhon Jaime Correa. «Disputas por la centralización/descentralización administrativa en el Viejo Caldas, 1905-1966: los casos de Manizales y Pereira». Anuario Colombiano de Historia Social y de la Cultura 39, n. ${ }^{\circ} 2$ (2012): 187-216. http://www.scielo.org.co/pdf/achsc/ v39n2/v39n2a08.pdf.

Moreno Sandoval, Armando. «El bandolerismo social revisitado. El caso del Norte del Tolima (Colombia)». Historelo Revista de Historia Regional y Local 4, n. ${ }^{\circ} 7$ (2012): 271-309. http://www.scielo.org.co/pdf/histo/v4n7/v4n7a11. pdf.

Ortiz Sarmiento, Carlos Miguel. «Los estudios sobre La Violencia en las tres últimas décadas». Boletín Socioeconómico, n. ${ }^{\circ}$ 24-25 (1992): 47-52. https://bibliotecadigital.univalle. edu.co/bitstream/handle/10893/5422/Los\%20estudios\%20 sobre $\% 20$ la $\% 20$ violencia $\% 20$ en $\% 20$ las $\% 20$ tres $\% 20$ ultimas\%20decadas.pdf? sequence $=1$ \&isAllowed $=\mathrm{y}$.

PÉCAUt, DANIEL. «De la violencia banalizada al terror: el caso colombiano». Controversia, n. ${ }^{\circ} 171$ (1997): 9-32. http:// biblioteca.clacso.edu.ar/Colombia/cinep/20100916014110/ politicaysociedaddelaviolenciabanalizadaControversia171. pdf.

Pizarro Leongómez, Eduardo. «La profesionalización militar en Colombia (III): los regímenes militares (1953-1958)». Análisis Político, n. 3 (1988): 20-39. https://revistas.unal.edu. co/index.php/anpol/article/view/73974/66905.

Restrepo, Fabricio. «Discurso de Sierra Ochoa en Anserma». Revista Candilejas (1954): 26-32. 
Rojas, Diana Marcela. "La Alianza para el progreso de Colombia». Revista Análisis Político, n. ${ }^{\circ} 70$ (2010): 91-124. http://www.scielo.org.co/pdf/anpol/v23n70/v23n70a06.pdf.

Ruiz Nova, Alberto. "La acción cívica en movimientos insurreccionales». Revista de las Fuerzas Militares, n. ${ }^{\circ} 21$ (1963): 491-495.

Steiner, Claudia. «Un bandolero para el recuerdo: Efraín González también conocido como "el siete colores"». Antípoda. Revista de Antropología y Arqueología, n. 2 (2006): 229-252. https://doi.org/10.7440/antipoda2.2006.12.

Uribe de Hincapié, María Teresa. «Las soberanías en disputa: ¿conflicto de identidades o de derechos?». Revista Estudios Políticos, n. ${ }^{\circ} 15$ (1999): 23-45.

Villanueva Martínez. Orlando. «Delincuentes: alias y vida cotidiana en Bogotá, 1963». Revista Historia Caribe 6, n. ${ }^{\circ} 18$ (2011): 105-125. http://investigaciones.uniatlantico.edu.co/ revistas/index.php/Historia_Caribe/article/view/10/8.

Zuleta, Mónica. "La Violencia en Colombia: avatares de la construcción de un objeto de estudio», Nómadas (Col), n. ${ }^{\circ} 25$ (2006): 54-69. https://www.redalyc.org/ pdf/1051/105115224006.pdf.

\section{Tesis}

Castro Morales, Daniel, «Modernización contrainsurgente: la acción cívico militar en Colombia y sus fuentes intelectuales (1958-1971)». (Trabajo de grado, Universidad de Antioquia, 2016). http://bibliotecadigital.udea.edu. co/bitstream/10495/13578/1/CastroMorales_2016_ Modernizaci\%c3\%b3nContraInsurgente.pdf. 
López G., Edwin Mauricio, «El espectro de la violencia y el fantasma del comunismo: cultura política e ideología conservadora en Caldas. 1953-1956». (Trabajo de grado, Universidad Tecnológica de Pereira, 2019). http://repositorio. utp.edu.co/dspace/bitstream/handle/11059/10095/ T306.2\%20L925.pdf? sequence $=1$ \&isAllowed $=\mathrm{y}$.

Maingot, Anthony, "Colombia: Civil-Military Relations in a Political Culture of Conflict». (Dissertation Ph.D., University of Florida, 1967).

Malott, David Edison, "Military Civic Action in Colombia». (Tesis de máster. Universidad de Florida, 1985). https://apps. dtic.mil/dtic/tr/fulltext/u2/a158207.pdf.

Mury, Willy, «Lármée colombienne. Etude dune institution militaire dans ses rapports avec la société en transition, 19301974». (Tesis doctoral, Universidad de París, 1975).

Nieto Ortiz, Pablo Andrés, «¿Subordinación o autonomía?: El Ejército colombiano, su relación política con el gobierno civil y su configuración en la violencia, 1953-1965». (Tesis de Maestría, Universidad Nacional de Colombia, 2010). https://repositorio.unal.edu.co/bitstream/handle/ unal/6721/468293.2010.pdf?sequence=1\&isAllowed $=$ y.

Perdomo Chamucero, Martha Patricia, «De La Violencia al Frente Nacional: evolución de la Justicia Penal Militar como instrumento de represión política y sanción de la protesta social». (Tesis de Maestría en Estudios Políticos, Universidad Nacional de Colombia, 2010). https://repositorio.unal. edu.co/bitstream/handle/unal/7482/6699041.2010. pdf? sequence $=1$ \&isAllowed $=y$. 
Rodríguez Durán, Ronal Fabián, «Rojas Pinilla ¿un dictador? De la dictadura positiva a la dictadura negativa» (Trabajo de grado, Universidad Colegio Mayor de Nuestra Señora del Rosario, 2006). https://repository.urosario.edu.co/bitstream/ handle/10336/2139/80151368.pdf? sequence $=1$.

\section{Sitios web}

Álvarez Mendoza, Héctor. «La Policía Nacional el 9 de abril de 1948», EJE 21, 11 de marzo de 2018. https://www.eje21. com.co/2018/03/el-senor-de-las-culebras/.

Cadavid Correa, Orlando. «Los nueve gobernadores militares de Caldas», EJE 21, 13 de marzo de 2016. https://www. eje21.com.co/2016/03/los-nueve-gobernadores-militaresde-caldas/.

Cardona, Alfredo. «Una joven valerosa», El Diario, 19 de noviembre de 2017. http://www.eldiario.com.co/seccion/ LAS+ARTES/una-joven-valerosa1711.html.

Correa Ramírez, Jhon Jaime; Natalia Agudelo Castañeda, Edwin Mauricio López García. «Los gobernadores Militares en Caldas» Corporación Piedramaní, 28 de septiembre de 2018, https://www.slideshare.net/CorporacinPiedraman/losgobernadores-militares-de-caldas.

De los Ríos Tobón, Ricardo. «Las diez ciudades de Manizales», La Patria. com. https://www.lapatria.com/especiales/papelsalmon/historia/las-diez-ciudades-de-manizales-325585.

EL PAís. «Los alias, más que una simple chapa». 09 de diciembre de 2005. http://historico.elpais.com.co/paisonline/notas/ Diciembre092005/A209N1.html. 
EJE 21. «El rincón de la memoria». 8 de junio de 2009. https:// www.eje21.com.co/2009/06/el-rincn-de-la-memoria/.

Federación Nacional De Departamentos. «Qué es una RAP».

s. f. https://fnd.org.co/fnd/inde.php?option=com content $\&$ view $=$ article\&id $=4489 \&$ catid $=21 \&$ Itemid $=233$ \#: :text=LA\%20RAP\%20(Regi\%C3\%B3n\%20Administ rativa\%20y,del\%20Ruiz)\%2C\%20generar\%20proyectos \%20deEl LiBro TotaL. «Discursos del general Gustavo Rojas Pinilla»., https://www.ellibrototal.com/ltotal $/ ? \mathrm{t}=1 \& \mathrm{~d}=4669$.

Institución Educativa Santa Teresita. «Un poco de historia». https://www.ie-santateresita.edu.co/un-poco-de-historia/.

LA CRÓNICA del Quindío. «RAP Eje Cafetero construye plan con visión a 16 años». 14 de febrero de 2020. https://www. cronicadelquindio.com/noticia-completa-titulo-rap-ejecafetero-construye-plan-con-vision-a-16-anos-cronica-delquindio-nota-136662.htm.

LA CRÓNICA DEL Quindío. «El último gobernador del Viejo Caldas», 10 de julio de 2016. https://www.cronicadelquindio.com/ noticias/region/el-ltimo-gobernador-del-viejo-caldas.

Pizarro León Gómez, Eduardo. «Marquetalia el mito fundacional de las Farc» U.N Periódico, 9 de mayo de 2004. http://historico.unperiodico.unal.edu.co/ediciones/57/03. htm.

Revista Semana. "Por sus alias los conoceréis», 11 de febrero de 2006. https://www.semana.com/por-aliasconocereis/76119-3/. 
Este libro terminó de imprimirse en Mayo del 2021, en los talleres gráficos de Gráficas Olímpica, bajo el cuidado de sus autores. Pereira, Risaralda, Colombia. 
Natalia Agudelo Castañeda (Manizales, Colombia, 1992).

Magíster (C) en Historia y Licenciada en Comunicación e Informática Educativa de la Universidad Tecnológica de Pereira. Es coautora de Facultad de Ciencias de la Educación UTP: 50 años en la Construcción de un Proyecto Educativo para una Nueva Región 1967-2017. Editorial UTP, 2018. Ha realizado ponencias en eventos académicos de carácter regional y nacional, $\mathrm{y}$ ha publicado artículos en revistas especializadas nacionales de su especialidad. Es integrante del Grupo interinstitucional de Investigación UIS-UTP "Políticas, Sociabilidades y Representaciones Histórico-Educativas (PSORHE)", clasificado en la categoría A1 ante Colciencias.

\section{nataagudelo@utp.edu.co}

Edwin Mauricio López García (Pereira, Colombia, 1986).

Licenciado en Etnoeducación y Desarrollo Comunitario y estudiante de la Maestría en Historia de la Universidad Tecnológica de Pereira. Coautor del libro 50/60 Una Historia Compartida (2016). Ha publicado artículos en revistas especializadas sobre clientelismo durante el Frente Nacional y el proceso de creación del Departamento de Risaralda.

\section{elopgar86@utp.edu.co}

Wilton Holguín Rotavista (Anserma, Colombia, 1995)

Licenciado en Ciencias Sociales de la Universidad de Caldas y estudiante de la maestría en Historia de la Universidad Tecnológica de Pereira. Es integrante del Grupo interinstitucional de Investigación UIS-UTP "Políticas, Sociabilidades y Representaciones Histórico-Educativas (PSORHE)".

w.holguin@utp.edu.co

Anderson Andrés López Urrea (Chinchiná, Colombia, 1996)

Licenciado en Ciencias Sociales de la Universidad de Caldas. Es autor de Breve historia de Chinchiná: una historia compartida desde las imágenes (2019).

anderson.211514008@ucaldas.edu.co 
Este libro resultado de investigación analiza desde distintas perspectivas la actuación de las Fuerzas Militares al mando del poder político durante la Dictadura de Rojas Pinilla (1953- 1957) y sus posteriores acciones cívico-militares hasta 1964 en la búsqueda de pacificar el departamento de Caldas (Colombia).

En los diferentes capítulos se aborda inicialmente el papel de la prensa caldense y las distintas etapas de la relación entre los militares y los dos partidos políticos tradicionales, como también el análisis de publicaciones impresas del primer gobernador Militar de Caldas durante el periodo de estudio, el coronel Gustavo Sierra Ochoa. Luego, se realiza un acercamiento a la acción cívico-militar que tuvo lugar en Caldas entre 1953 y 1964, para dar paso a un análisis a profundidad de un sumario por el delito de "Asociación para delinquir" en contra de trece campesinos de Belalcázar (Caldas) en 1958. Por último, el libro cierra con un capítulo en el que se analizan las acciones administrativas y cívicas del Consejo Administrativo Municipal y la Junta Patriótica Auxiliar en el municipio de Chinchiná (Caldas) durante el gobierno militar de Gustavo Rojas Pinilla (1953-1957). Tras la lectura del libro se logra afirmar que el desarrollo de este proceso derivó en balance pírrico de "pacificación sin paz", lo que nos permite aseverar que la pacificación y el retorno de la democracia que lideraron las Fuerzas Armadas se dio en el marco de un complejo entramado de intereses, conflictos y prevenciones, de legitimación de posturas autoritarias como el cierre de órganos legislativos y de control político, de declaratorias de estado de sitio y restricciones a la libertad de prensa, bajo la pretensión de salvaguardar el orden público y la democracia.

eISBN: 978-958-722-484-9

ISBN: 978-958-722-482-5

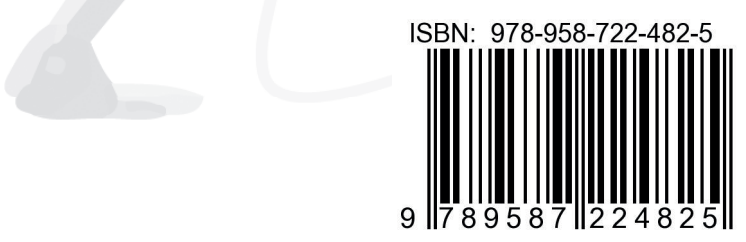

